GISELLE DE AMARO E FRANÇA

\title{
O PODER JUDICIÁRIO E AS POLÍTICAS PÚBLICAS PREVIDENCIÁRIAS
}

Universidade de São Paulo

Faculdade de Direito

São Paulo - 2010 
GISELLE DE AMARO E FRANÇA

\section{O PODER JUDICIÁRIO E AS POLÍTICAS PÚBLICAS PREVIDENCIÁRIAS}

Dissertação apresentada ao

Departamento de Direito do Trabalho e Seguridade Social da Universidade de São Paulo como exigência parcial para obtenção do grau de mestre em Direito do Trabalho e Seguridade Social, sob a orientação do Professor Associado Marcus Orione Gonçalves Correia.

Universidade de São Paulo

Faculdade de Direito

São Paulo - 2010 
GISELLE DE AMARO E FRANÇA

\section{O PODER JUDICIÁRIO E AS POLÍTICAS PÚBLICAS PREVIDENCIÁRIAS}

Universidade de São Paulo

Faculdade de Direito

São Paulo - 2010 
DEDICATÓRIA

À memória da minha irmã, Karin França, anjo da guarda que sempre me ilumina, aos meus pais, Shirley e Waldéris, pela força e compreensão nos momentos difíceis e pelo exemplo de superação nos embates da vida, e aos meus sobrinhos Gabriela e Rafael, pela alegria de viver, dedico este trabalho. 


\section{AGRADECIMENTOS}

Ao Professor Marcus Orione Gonçalves Correia, agradeço a confiança, a orientação firme e constante e, sobretudo, por novamente despertar em mim, pelo seu exemplo como Professor e Juiz, a vontade incessante de estudar.

Aos Professores Maria Paula Dallari Bucci e Paulo Eduardo Vieira de Oliveira, agradeço a gentileza da participação na banca de qualificação e as valiosas contribuições ao aprimoramento do trabalho.

À minha prima Kelen Luíza Giordano Amaro e ao amigo José Eduardo de Almeida Leonel Ferreira, por toda força e ajuda, agradeço de coração.

Aos colegas do programa de pós-graduação da Faculdade de Direito da Universidade de São Paulo Fernando Marques de Campos, Flávio Roberto Batista, José Antonio Savaris, Lucyla Tellez Merino, Marco Aurélio Serau Júnior, Renato Negretti Cruz, Ricardo Pires Calciolari e Thiago Barison de Oliveira, agradeço pela convivência e pelo estudo conjunto durante todo este período.

Aos colegas do Tribunal Regional Federal da $3^{\mathrm{a}}$ Região, desembargadores, juízes e servidores, agradeço por toda a ajuda e, especialmente, aos Desembargadores Federais Sérgio Nascimento, Carlos André de Castro Guerra e Jediael Galvão Miranda (in memoriam), pela oportunidade de vivenciar o Direito Previdenciário e pelas lições de vida contidas nos seus julgados. 


\section{RESUMO}

O estudo das políticas públicas recentemente tem despertado a atenção da doutrina no âmbito do Direito. O presente trabalho busca apresentar um quadro geral das políticas públicas previdenciárias, demonstrando a intersecção existente entre o Direito e a Ciência Política, as contribuições de cada disciplina e as tênues fronteiras que as separam.

A esfera do Direito, sob a perspectiva do Poder Judiciário, estabelece os parâmetros e limites do controle dos atos editados pelos outros Poderes, à luz dos instrumentos jurídicos previstos no ordenamento, tendo como objetivo a efetivação do direito fundamental à previdência social.

A análise de casos concretos, colhidos da jurisprudência pátria, revela alguma oscilação do Poder Judiciário na defesa do direito fundamental em questão, especialmente em decorrência de argumentos de natureza econômica, introduzidos no texto constitucional por meio das reformas de 1998 e 2003.

Palavras-chave: Políticas públicas; Direito Previdenciário; Controle Judicial. 


\begin{abstract}
The analysis of public policies has recently raised the attention in the scope of law. This study has the purpose of presenting a comprehensive view of the public policies on Social Security, by demonstrating the intersection between Law and Political Science, the contributions of each area of study as well as the tenuous frontiers separating them.

The scope of law, under the perspective of the Judiciary, establishes the patterns and the limits to regulate the measures taken by Executive and Legislative Power, having as reference the juridical instruments stated by the legal system, whose purpose is to safeguard the right to social security.

The analysis of concrete cases, gathered from the Brazilian case law, reveals a lack of coherence and consistency of the Judiciary to uphold the right to social security. This incoherence and inconsistency are mainly due to economic arguments, which were introduced in the Constitution by the time of the reforms carried out in 1998 and 2003.
\end{abstract}

Keywords: Public Policies; Social Security Act; Judicial Review. 


\section{SUMÁRIO}

\section{INTRODUÇÃO, 11}

\section{O DIREITO FUNDAMENTAL À PREVIDÊNCIA SOCIAL E AS POLÍTICAS PÚBLICAS PREVIDENCIÁRIAS, 15}

1.1. Políticas públicas: uma abordagem interdisciplinar, 15

1.2. Políticas de Estado e Políticas de Governo, 17

1.3. A questão democrática, 22

1.4. Direitos fundamentais sociais, 28

1.4.1. A justiciabilidade dos direitos fundamentais sociais, 30

1.4.2. Restrições, 33

1.5. O direito fundamental à previdência social e as políticas públicas previdenciárias, 35

1.5.1. Uma breve análise histórica, 36

1.5.2. Estado de Bem-Estar Social no Brasil, 40

1.5.3. A influência dos postulados neoliberais, 45

1.5.3.1. Emenda Constitucional no $20 / 1998,50$

1.5.3.2. Emenda Constitucional $n^{\circ} 41 / 2003,55$

1.5.3.3. Projeto de Emenda Constitucional n ${ }^{\circ} 341 / 2009,56$

1.5.3.4. Dois outros significativos exemplos da influência neoliberal na Constituição Federal: o equilíbrio financeiro e atuarial e a desvinculação das receitas da União, 58

1.5.3.4.1. Equilíbrio financeiro e atuarial, 58

1.5.3.4.2. Desvinculação das Receitas da União, 62

1.5.4. Limites possíveis das reformas previdenciárias, 64

1.6. Políticas públicas previdenciárias, 67

1.6.1. Política de Estado, 67

1.6.2. Políticas de Governo, 68

\section{O PODER JUDICIÁRIO, 70}

2.1. O Judiciário como Poder de Estado, 70 
2.2. O Judiciário como ator político, 72

2.3. A legitimidade do Poder Judiciário e a questão democrática, 76

2.4. Ativismo judicial, 79

2.5. Controle judicial de políticas públicas, 82

2.5.1. Aspectos gerais do controle de constitucionalidade no direito brasileiro, 82

2.5.2. Objeto, 83

2.5.3. Parâmetros do controle judicial, 85

2.5.3.1. Princípios e regras, 85

2.5.3.2. Alguns princípios de conotação especial em matéria previdenciária, 88

2.5.3.2.1. Princípio da solidariedade, 89

2.5.3.2.2. Princípio da unidade da Constituição, 90

2.5.3.2.3. Princípio da vedação do retrocesso, 91

2.5.3.2.4. Princípio da razoabilidade, 92

2.5.3.2.5. Proporcionalidade, 94

2.5.3.2.6. Eficiência, 96

2.5.4. Limites, 97

2.6. Reserva do possível, 103

2.7. Políticas públicas e ações coletivas, 110

3 O CONTROLE JUDICIAL DAS POLÍTICAS PÚBLICAS PREVIDENCIÁRIAS, 113

3.1. Análise de casos, 113

3.1.1. Valor do benefício: cálculo da renda mensal inicial, 113

3.1.1.1. Fator previdenciário, 116

3.1.2. Beneficiários: companheiros homossexuais, 121

3.1.3. Beneficiários: menor sob guarda, 125

3.1.4. Benefício de auxílio-doença: Programa de Cobertura Previdenciária Estimada (COPES) - Alta Programada, 130

3.1.5. Custeio - Regime Geral de Previdência Social: obrigatoriedade de recolhimento de contribuições previdenciárias pelo segurado aposentado que volta a trabalhar, 134

3.1.6. Custeio - Regime Próprio de Previdência Social: contribuição previdenciária dos servidores públicos inativos, 137 
3.1.7. Omissão legislativa - Regime Próprio de Previdência Social: serviço público exercido em condições penosas, insalubres ou perigosas, 143

3.2. O Poder Judiciário e as ações coletivas em questões previdenciárias, 146

3.3. Algumas conclusões, 150

CONCLUSÃO, 154

BIBLIOGRAFIA, 159 


\section{INTRODUÇÃO}

A Constituição Federal de 1988 consolidou um importante avanço no âmbito dos direitos sociais. Pela primeira vez na história constitucional brasileira, eles foram expressamente inseridos na classe dos direitos fundamentais, passando a usufruir do mesmo status conferido aos direitos individuais, quer em relação à sua salvaguarda por cláusula pétrea, quer quanto ao estabelecimento de garantias e instrumentos necessários a concretizá-los.

Saúde, Previdência Social e Assistência Social tornaram-se os pilares da Seguridade Social, regida por princípios específicos e realizada com um orçamento próprio.

O sistema de proteção social desenhado pelo legislador constituinte de 1988 é característico do Estado de Bem-Estar Social, fundado, essencialmente, na forte e prioritária atuação estatal na busca do bem-estar da coletividade, em seu grau máximo.

Tal avanço, é bom dizer, ocorreu tardiamente no Brasil já que a partir da década de 70 vários países (como a Inglaterra, os Estados Unidos, o Chile, etc.) trilhavam o caminho oposto, mediante a redução da atuação estatal em algumas de suas tarefas típicas, sob o embalo da onda neoliberal.

A conquista firmada na Constituição Federal, no entanto, nem sequer chegou a ser concretizada em toda a sua extensão. Passada uma década da sua promulgação, o texto originário sofreu várias alterações que refletem a influência das ideias neoliberais, inclusive no âmbito da Previdência Social.

Assistimos a uma mudança no projeto original de Seguridade Social gravado em sede constitucional e regulamentado pela legislação infraconstitucional. Em outros termos: mudaram as diretrizes e mudaram as ações voltadas a concretizá-las.

Falamos aqui de política de Estado e políticas de Governo, espécies do gênero políticas públicas, como será desenvolvido ao longo do Capítulo 1.

Para os fins deste trabalho, em que se pretende fixar as linhas gerais da evolução do modelo de Previdência Social no Brasil, o termo políticas públicas será abordado em sua dupla conotação.

Embora pareça redundante, é fundamental fixar a premissa de que as políticas públicas se formam no âmbito da Política, mediante a interação de inúmeros fatores de 
ordem social, política, econômica, financeira, internacional, entre outros. Trata-se, por tal razão, de uma questão interdisciplinar.

Uma vez elaboradas no universo próprio, elas ingressam no ordenamento jurídico, sendo por ele conformadas, de acordo com os seus parâmetros. Algumas delas demandam a alteração do texto constitucional por se mostrarem incompatíveis com as deliberações políticas anteriores; outras são introduzidas na ordem jurídica por meio da legislação infraconstitucional, vez que em suposta consonância com o regramento constitucional já existente.

A alteração das normas constitucionais é permitida, desde que atendidas duas condições: (i) preservação das cláusulas pétreas, inscritas no $\S 4^{\circ}$ do artigo 60; (ii) observância de procedimento legislativo especial.

Os direitos fundamentais, individuais e sociais, estão acobertados por cláusulas pétreas, pelo que nenhuma reforma constitucional tem o condão de reduzi-los ou suprimilos. Tarefa necessária, então, é buscar o conteúdo do direito fundamental em toda a sua extensão, pressuposto essencial para tornar possível a sua preservação.

Estabelecido o que é o direito fundamental à previdência social e, em consequência, o que está a salvo de qualquer alteração reducionista posterior, o item final do Capítulo 1 se destina a analisar se as mudanças feitas na Constituição Federal, sobretudo a partir de 1998, ferem o conteúdo do direito social em questão.

Desta forma, tanto a política de Estado (prevista no texto originário e posteriormente modificada) como as políticas de Governo (definidas como "arranjos institucionais complexos, expressos em estratégias ou programas de ação governamental, que resultam de processos juridicamente regulados, visando adequar meios e fins"1) devem estar em conformidade com o direito fundamental que pretendem realizar, cada qual na sua própria dimensão.

A análise da pertinência e da compatibilidade entre a política de Estado originária e as alterações introduzidas posteriormente, bem como entre as políticas de Governo e a política de Estado, sempre tendo como referência o direito fundamental, é atribuição típica do Poder Judiciário, órgão estatal que deve dizer o direito, por desejo expresso do próprio legislador constituinte. Este é o objeto do Capítulo 2.

\footnotetext{
${ }^{1}$ Confira-se o artigo de BUCCI, Maria Paula Dallari. Notas para uma metodologia jurídica de análise de políticas públicas. In FORTINI, Cristiana; ESTEVES, Júlio César dos Santos; DIAS, Maria Tereza Fonseca (orgs.). Políticas públicas: possibilidades e limites. Belo Horizonte: Editora Fórum, 2008. p. 251.
} 
De se ressaltar que também nesta seara foi grande o passo dado em 1988, pois o Judiciário foi dotado de poderes e atribuições suficientes a caracterizá-lo como verdadeiro ator político, participando das decisões políticas fundamentais.

Não estamos com isso querendo dizer que o Poder Judiciário é o órgão responsável pela tomada das decisões políticas, mesmo porque ele não tem legitimação constitucional para tanto, mas sim que a ele compete dizer se a opção política está ou não em consonância com a ordem jurídica.

É certo, contudo, que no exercício de suas funções o Judiciário acaba por participar do jogo político na medida em que a preservação da ordem jurídica, especialmente do conteúdo das cláusulas pétreas, pode barrar a concretização de novas políticas públicas, em razão de sua incompatibilidade com o sistema jurídico.

Buscaremos elucidar as discussões mais relevantes acerca da legitimidade da atuação judicial e dos limites impostos ao Poder Judiciário no controle dos atos praticados pelos demais Poderes, também no exercício de suas funções típicas, procurando estabelecer as tênues fronteiras entre um e outro, de forma que preserve a independência e a harmonia entre eles, como determina o artigo $2^{\circ}$ da Constituição Federal. Para tanto, serão abordados alguns dos princípios que consideramos essenciais à análise judicial, na medida em que possibilitam uma interpretação eminentemente social, a única a realizar, em toda a sua extensão, os objetivos do Estado democrático brasileiro, nos termos dos $\operatorname{artigos} 1^{\circ}$ e $3^{\circ}$ da Constituição Federal.

Ainda no Capítulo 2, será destacada a importância das ações coletivas como instrumento processual adequado para veicular os conflitos envolvendo o direito fundamental à previdência social e as políticas públicas. Duas são, ao menos, as vantagens apresentadas: (i) possibilitar o acesso à justiça aos desprovidos de recursos (que representam a grande parte dos beneficiários - segurados e dependentes - da Previdência), legitimando órgãos dotados de estrutura e capacidade suficientes a ajuizar tais demandas, tendo por objeto a defesa de interesses difusos, coletivos e individuais homogêneos; (ii) racionalizar a prestação jurisdicional, ensejando que conflitos envolvendo questões da mesma natureza sejam resolvidos mediante a mais ampla dilação probatória e de forma equitativa para os que se encontram na mesma situação, trazendo a necessária segurança jurídica e, quiçá, alguma pacificação social.

Definidos os contornos do direito fundamental à previdência social, as políticas públicas previdenciárias e os parâmetros de atuação do Poder Judiciário no seu controle, serão abordados no Capítulo 3 alguns casos concretos levantados na jurisprudência 
brasileira, aptos a demonstrar a interação entre Direitos Fundamentais - Políticas Públicas - Controle Judicial.

O trabalho proposto se mostra árduo pelo menos por duas razões.

Em primeiro lugar, é bom ser dito que apenas recentemente o estudo das políticas públicas chamou a atenção dos doutrinadores, sendo poucas as obras editadas sobre o assunto, especialmente na área do Direito. Talvez uma das respostas possíveis para esta constatação já tenha sido mencionada: como se trata de um tema interdisciplinar, reconhecer as fronteiras entre o Direito e os demais ramos envolvidos nem sempre é fácil. Para além disso, o Direito se inter-relaciona com a questão das políticas públicas em alguns pontos, mas não consegue abarcá-las em sua inteireza. A nós, operadores do Direito, cumpre identificar referido campo de intersecção e utilizar as ferramentas existentes para a preservação da ordem jurídica, respeitando, contudo, as deliberações tomadas nas outras esferas.

Em segundo lugar, o objeto de nosso estudo - políticas públicas previdenciárias não nos ajuda muito em termos de organicidade e sistematização. De um lado, assistimos a uma alteração da política previdenciária de Estado, antes mesmo de integralmente regulamentada e efetivada; de outro lado, a legislação infraconstitucional ora se dedica a regulamentar as diretrizes constitucionais em sentido absolutamente contrário ou de forma incompleta, ora nem sequer o faz; em alguns casos, é certo, atende aos parâmetros preestabelecidos. Além do que, tanto uma quanto a outra devem ser cotejadas com o direito fundamental à previdência social, cujo conteúdo não está definido em um único dispositivo, mas deve ser apreendido entre os vários que cuidam da matéria, cabendo ao intérprete, antes de tudo, definir qual a sua real extensão.

Cientes das dificuldades envolvidas no estudo, passamos então a discutir algumas questões que consideramos importantes ao estudo do controle judicial das políticas públicas previdenciárias. 


\section{O DIREITO FUNDAMENTAL À PREVIDÊNCIA SOCIAL E AS POLÍTICAS PÚBLICAS PREVIDENCIÁRIAS}

\subsection{Políticas públicas: uma abordagem interdisciplinar}

A expressão políticas públicas é um termo polissêmico que, por si só, já denota seu vasto campo de abrangência. Envolve questões políticas, questões de interesse público, gestão da coisa pública, em suma, abarca as principais discussões acerca das opções políticas realizadas para a satisfação dos interesses gerais da coletividade, mediante utilização dos recursos públicos.

Por aí já se percebe que a sua análise exige sejam considerados institutos pertencentes a ramos diversos da ciência e sejam ultrapassados os limites do conhecimento técnico e específico, voltando-se os olhos para o todo. É por isso que se trata, essencialmente, de um estudo interdisciplinar. ${ }^{2}$

Não é possível entender como se formam, como se executam e como se controlam as políticas públicas sem saber, entre outros: $(i)$ qual o grau de democracia da sociedade em questão (Ciência Política e Sociologia); (ii) quais são os Poderes de Estado e como são divididas suas competências (Ciência Política e Direito); (iii) quais são os valores fundamentais eleitos pela coletividade a nortear suas ações (Filosofia e Direito); (iv) como se ordenam os comandos constitucionais, os atos legislativos infraconstitucionais e as eventuais limitações à consecução dos direitos fundamentais (Ciência Política, Direito e Economia); (v) por que razões determinados temas são objetos de políticas públicas e outros não, onde estão e quais são os limites de discricionariedade do administrador público (Ciência Política, Direito e Economia); (vi) qual é o âmbito de intervenção do Poder Judiciário nesta seara, considerando a independência entre os Poderes (Ciência Política e Direito).

\footnotetext{
${ }^{2}$ Não há um conceito único para o termo interdisciplinaridade, mas todas as definições apresentadas giram em torno do mesmo princípio, qual seja, a intensidade das trocas entre os especialistas e a integração das disciplinas num mesmo projeto de pesquisa. A tendência mais acentuada é a utilização de quatro conceitos (pluri, multi, inter e transdisciplinaridade), graus diversos de uma mesma escala, a depender da esfera de coordenação e cooperação entre as disciplinas (FAZENDA, Ivani. Interdisciplinaridade: um projeto em parceria. São Paulo: Edições Loyola, 2002. p. 31).
} 
Bem adverte Maria Paula Dallari Bucci que

definir as políticas públicas como campo de estudo jurídico é um movimento que faz parte de uma abertura do direito para a interdisciplinaridade. Alguns institutos e categorias jurídicas tradicionais, hoje despidos de seu sentido legitimador original, buscam novo sentido ou nova força restabelecendo contato com outras áreas do conhecimento, das quais vinha se apartando desde a caminhada positivista que se iniciou no século XIX. Ter-se firmado como campo autônomo, dotado de "objetividade" e "cientificidade" - desafios do positivismo jurídico -, é um objetivo até certo ponto realizado pelo Direito, o que permite a seus pesquisadores voltar os olhos às demandas sociais que fundamentam a construção das formas jurídicas. ${ }^{3} /^{4}$

Esta abertura para outros campos do conhecimento não significa, para qualquer deles, a perda de sua identidade original.

Pelo contrário.

É essencial que cada ramo do saber não deixe de lado suas características básicas, que na troca de conhecimentos com outras disciplinas saiba doar e receber sem se desfigurar. É justamente aí que reside a riqueza do estudo interdisciplinar.

A interdisciplinaridade exige uma nova postura do observador, de forma que reconheça sua limitação de abarcar, sozinho, todas as questões envolvidas. Significa admitir, em suma, que o seu olhar é apenas um dos olhares possíveis.

Gilberto Bercovici, com amparo em Lourdes Sola, demonstra de maneira bastante feliz os riscos de uma análise compartimentada. Afirma que

\begin{abstract}
um equívoco comum nas análises políticas é a incorporação do erro cometido pelos economistas, que atribuem o fracasso das políticas econômicas aos equívocos de teoria econômica em sua elaboração. Falta, em sua opinião, a inclusão de outra causalidade: a política é institucional (e jurídica, incluiríamos). Os resultados das políticas econômicas não dependem apenas de sua coerência econômica, mas também de sua viabilidade política e das opções institucionais.
\end{abstract}

\footnotetext{
${ }^{3}$ BUCCI, Maria Paula Dallari. O conceito de política pública em direito. In: BUCCI, Maria Paula Dallari (org.). Políticas Públicas: reflexões sobre o conceito jurídico. São Paulo: Saraiva, 2006. p. 2.

${ }^{4}$ Para Hilton Japiassu, "o positivismo foi o grande responsável por essa situação de fragmentação das ciências do homem, na medida em que seus métodos apresentam sérias lacunas. Com efeito, dado que essa filosofia das ciências limita enormemente o campo das disciplinas e que reduz seu domínio única e exclusivamente aos fenômenos observáveis, portanto, à descrição e ao processo de relacionar fatos, torna-se patente que não consegue outra coisa senão descobrir um conjunto de leis funcionais. O resultado é que ela fragmenta o real num determinado número de territórios separados, numa série de estágios superpostos, só podendo corresponder a domínios por demais delimitados das diversas disciplinas. Uma consequência dessa atitude intelectual é que fica excluída, de antemão, toda e qualquer metodologia interdisciplinar, cujo princípio mesmo é o contraditório com o das fronteiras consideradas como definitivas. O fenômeno humano não é mais conhecido na plenitude de sua significação. Uma disciplina qualquer, cujo estatuto permanece fixo uma vez por todas, mesmo que pretenda interessar-se pelo homem, jamais poderá encontrá-lo, sempre fornecendo dele um conhecimento parcial e truncado, já que aborda os fatos humanos sob o ângulo de um determinismo particular, extremamente restritivo" (Interdisciplinaridade e Patologia do Saber. Rio de Janeiro: Imago Editora Ltda., 1976. p. 61-62).
} 
Isto é ainda mais facilmente perceptível no caso das políticas de desenvolvimento de longo prazo cujo objetivo seja a melhoria das condições sociais da população. E a análise do caso brasileiro revela que o processo de desenvolvimento funda-se em decisões políticas. ${ }^{5}$

Portanto, antes de adentrar no campo jurídico, objeto deste trabalho, é necessário buscar na esfera da Ciência Política os institutos que integram o conceito de políticas públicas.

\subsection{Políticas de Estado e Políticas de Governo}

A expressão políticas públicas comporta duas dimensões.

A primeira delas trata das opções políticas relacionadas à estrutura do Estado, dispondo sobre as formas de organização e funcionamento do aparelho estatal, os valores fundamentais positivados e as diretrizes que devem nortear a efetivação dos objetivos lançados. São as denominadas "políticas de Estado", opções políticas que indicam e orientam o modelo de ação estatal a longo prazo, independentemente do programa de governo $x$ ou $y$.

Embora geralmente as políticas de Estado se encontrem inscritas no texto constitucional, não é correto afirmar que se trata de políticas de Estado apenas e tão somente porque ali estão. Existem inúmeros dispositivos constitucionais que não guardam qualquer relação com tais diretrizes de atuação estatal, não traduzindo assim nenhuma opção política relativa a um valor fundamental ou à estrutura do Estado. De outro lado, é possível que algumas políticas de Estado delineadas na Constituição Federal sejam regulamentadas por lei (ordinária e complementar), que desta forma também se caracteriza como política de Estado, em conjunto com a diretriz constitucional.

De acordo com Fernando Aith,

quando a política pública tiver como objetivos a consolidação institucional da organização política do Estado, a consolidação do Estado Democrático de Direito e a garantia da soberania nacional e da ordem pública, ela poderá ser considerada política de Estado. Dentro desse quadro, pode-se afirmar, ainda, que uma política é de Estado quando voltada a estruturar o Estado para que este

\footnotetext{
${ }^{5}$ BERCOVICI, Gilberto. Planejamento e políticas públicas: por uma nova compreensão do papel do Estado. In BUCCI, Maria Paula Dallari (org.). Políticas Públicas: Reflexões sobre o Conceito Jurídico. São Paulo: Saraiva, 2006. p. 144.
} 
tenha as condições mínimas para a execução de políticas de promoção e proteção dos direitos humanos. ${ }^{6}$

A doutrina também utiliza o termo "Política constitucional" (Polity) para designar a política de Estado. ${ }^{7}$

Já a segunda dimensão contempla as opções políticas mais concretas e específicas, voltadas a resolver questões definidas, mediante a utilização de meios previamente estabelecidos e em espaço de tempo delimitado. Trata-se do sentido estrito da expressão políticas públicas, também denominadas políticas de Governo ou policies.

Ainda de acordo com Fernando Aith,

as políticas de governo podem ser políticas pontuais, voltadas à promoção dos direitos humanos, dotadas de uma maior flexibilização e de maior especificidade em seus objetivos. Os objetivos das políticas de governo são o de aumentar a eficácia e a efetividade das ações de promoção e proteção dos direitos humanos, através da estrutura estatal já existente e utilizando-se dos mecanismos democráticos já estabelecidos.

Em suma:

a política de Estado é voltada a organizá-lo, de modo que ele tenha as bases estruturais mínimas para a execução de políticas de promoção e proteção dos direitos humanos. Já as políticas de governo, utilizando-se dessas bases estruturais já consolidadas, são implementadas para promover ações pontuais de proteção e promoção aos direitos humanos específicos expressos em nossa Carta. 89

No sentido estrito, políticas públicas são um conjunto de processos, incluindo, ao menos: a definição da agenda; a elaboração de alternativas que serão objeto de escolha;

${ }^{6}$ AITH, Fernando. Políticas públicas de Estado e de governo: instrumentos de consolidação do Estado de Direito e de promoção dos direitos humanos. In BUCCI, Maria Paula Dallari (org.). Políticas Públicas: Reflexões sobre o Conceito Jurídico. São Paulo: Saraiva, 2006. p. 235.

7 A política constitucional "define a estruturação básica do Estado, a sua conformação normativa fundamental, que expressa a correlação de forças sociais e políticas vigentes, assim como os valores e crenças fundamentais e politicamente relevantes de uma dada sociedade" (COUTO, Cláudio Gonçalves. Política constitucional, política competitiva e políticas públicas. In: BUCCI, Maria Paula Dallari (org.). Políticas Públicas: reflexões sobre o conceito jurídico. São Paulo: Saraiva, 2006. p. 98). Concordamos parcialmente com a afirmação, visto que nem toda norma inscrita na Constituição está relacionada com as escolhas políticas mencionadas pelo Autor.

${ }^{8}$ AITH, Fernando. Políticas públicas de Estado e de governo: instrumentos de consolidação do Estado de Direito e de promoção dos direitos humanos. In BUCCI, Maria Paula Dallari (org.). Op. cit., p. 236.

${ }^{9}$ Para o Autor (Op. cit.), as políticas de Estado e de Governo se diferenciam em três questões: $(i)$ nos objetivos perseguidos; (ii) na forma de elaboração, planejamento e execução (as políticas de Estado são necessariamente elaboradas, planejadas e executadas pelo Estado, não sendo passíveis de delegação ou terceirização - salvo de forma subsidiária e subordinada - ou de quebra de continuidade, ao passo que as políticas de Governo podem ser delegadas ou terceirizadas, além de serem interrompidas ou substituídas por outra); (iii) na forma de financiamento (as políticas de Estado são sempre financiadas com recursos públicos, oriundos da arrecadação tributária, e as políticas de Governo podem contar com recursos privados em sua implementação, desde que sob a fiscalização do Poder Público). 
uma escolha confiável, respeitável e irrefutável entre as alternativas postas, como no caso de um voto legislativo ou de uma decisão presidencial; e a execução da decisão. ${ }^{10}$

O caráter temporal e específico das políticas de governo recomenda que elas não sejam inscritas no texto constitucional, no mínimo por duas razões: (i) dificultam, e muito, qualquer possibilidade de alteração do plano traçado, ainda que comprovadamente insuficiente, pois como toda regra constitucional exige processo legislativo diferenciado de reforma (artigo 60 da Constituição Federal); (ii) embora conceitualmente se tratem de programas voltados a resolver questões específicas, visando o bem-estar da coletividade, acabam por engessar as gerações futuras, causando um verdadeiro 'déficit de democracia' por inibir que a maioria, em dado momento, tome as decisões que julgar mais favoráveis.

A Professora Maria Paula Dallari Bucci, uma das precursoras no estudo das políticas públicas no Brasil, utiliza o termo no sentido restrito acima indicado e as define como "arranjos institucionais complexos, expressos em estratégias ou programas de ação governamental, que resultam de processos juridicamente regulados, visando adequar meios e fins". ${ }^{11}$

Merece ser aqui registrada a evolução do conceito apresentado pela Autora.

Inicialmente, foi utilizada uma definição mais restrita, considerando as políticas públicas como "programas de ação governamental visando a coordenar os meios à disposição do Estado e as atividades privadas, para a realização de objetivos socialmente relevantes e politicamente determinados" ${ }^{\prime 2}$. Neste primeiro conceito não foi abordado o aspecto processual, ou seja, a política pública vista como conjunto ordenado de atos.

Mais a seguir, no texto "O conceito de política pública em direito"13, foi introduzida a questão processual, definindo-se política pública como

\begin{abstract}
o programa de ação governamental que resulta de um processo ou conjunto de processos juridicamente regulados - processo eleitoral, processo de planejamento, processo de governo, processo orçamentário, processo legislativo, processo administrativo, processo judicial - visando coordenar os meios à disposição do Estado e as atividades privadas, para a realização de objetivos socialmente relevantes e politicamente determinados.
\end{abstract}

\footnotetext{
${ }^{10}$ Nas palavras do Autor: "Though a drastic oversimplification, public policy making can be considered to a set a processes, including at least (1) the setting of the agenda, (2) the specification of alternatives from wich a choice is to be made, (3) an authoritative choice among those specified alternatives, as in a legislative vote or a presidencial decision, and (4) the implementation of the decision" (KINGDON, John W. Agendas, alternatives, and public policies. 2. ed. New York: Longman, 1995. p. 2-3).

${ }^{11}$ Confira-se o artigo "Notas para uma metodologia jurídica de análise de políticas públicas". In FORTINI, Cristiana; ESTEVES, Júlio César dos Santos; DIAS, Maria Tereza Fonseca (orgs.). Op. cit., p. 251.

${ }^{12}$ Direito administrativo e políticas públicas. São Paulo: Saraiva, 2002. p. 241.

${ }^{13}$ In BUCCI, Maria Paula Dallari (org.). Op. cit., p. 39.
} 
Como tipo ideal, a política pública deve visar a realização de objetivos definidos, expressando a seleção de prioridades, a reserva de meios necessários à sua consecução e o intervalo de tempo em que se espera o atingimento dos resultados.

Após percorrer tal trajetória, conclui a Autora que mais importante do que o conceito em si é o estabelecimento de uma metodologia de análise jurídica, em razão do caráter interdisciplinar da política pública, posição com a qual compartilhamos.

É na esfera da Ciência Política que se encontram os elementos necessários para a formulação do conceito em sua inteireza, já que a opção por um ou outro caminho é eminentemente política e não jurídica.

Por tal razão, por mais completo que se pretenda o conceito jurídico do termo, dificilmente terá o condão de englobar todas as questões envolvidas.

Desta forma, ao Direito cabe conformar as deliberações políticas tomadas em âmbito próprio, mediante os contornos jurídicos admitidos. Aos operadores do Direito, por sua vez, compete verificar a consonância das opções políticas com as normas já existentes, mantendo a integridade da ordem jurídica. ${ }^{14}$

Admitida, pois, a insuficiência do Direito em disciplinar todas as fases do processo político decisório, vamos buscar na teoria política as principais explicações invocadas para justificar a tomada de uma decisão ou outra. ${ }^{15}$

$\mathrm{Na}$ obra Agendas, alternatives, and public policies, John Kingdon apresenta o modelo dos múltiplos fluxos (Multiple Streams Model) ${ }^{16}$, apontando a existência de quatro processos na formação das políticas públicas: $(i)$ o estabelecimento de uma agenda de políticas públicas (agenda setting); (ii) a consideração das alternativas para a formulação de políticas públicas (policy stream); (iii) a escolha dominante entre o conjunto de alternativas disponíveis; e (iv) a implementação da decisão. ${ }^{17}$

\footnotetext{
${ }^{14}$ Esta discussão será objeto do Capítulo 2, cujo foco é o controle judicial das políticas públicas.

${ }^{15}$ Como o objeto deste trabalho não é o estudo das políticas públicas em sua fase de formação, mas sim sob a ótica do controle judicial, não se debruçará sobre a exposição detalhada das principais teorias elaboradas na área da Ciência Política para a explicação do fenômeno, considerando suficiente aquela formulada por John Kingdon, amplamente aceita e utilizada pelos estudiosos da esfera política.

${ }^{16} \mathrm{O}$ modelo de John Kingdon foi formulado em 2003 para analisar as políticas públicas nas áreas de saúde e transporte do governo federal norte-americano e é adotado como referência nos estudos do tema. Ele caracteriza o governo federal norte-americano como uma "anarquia organizada", identificando a ocorrência de três fluxos decisórios, que seguem seu curso de forma relativamente independente e convergem em momentos críticos, ocasiões em que se dá a mudança de agenda (CAPELLA, Ana Cláudia N. Perspectivas Teóricas sobre o Processo de Formulação de Políticas Públicas. In HOCHMAN, Gilberto; ARRETCHE, Marta; MARQUES, Eduardo (orgs.). Políticas públicas no Brasil. Rio de Janeiro: Editora Fiocruz, 2007, p. 89).

${ }^{17}$ CAPELLA, Ana Cláudia N. Perspectivas Teóricas sobre o Processo de Formulação de Políticas Públicas. In HOCHMAN, Gilberto; ARRETCHE, Marta; MARQUES, Eduardo (orgs.). Políticas públicas no Brasil. Rio de Janeiro: Editora Fiocruz, 2007. p. 88.
} 
O modelo identifica a existência de três fluxos decisórios (streams), que seguem seu curso de forma autônoma:

a) $\quad 1^{\circ}$ fluxo - agenda setting: nesta fase, o modelo analisa por que determinadas questões são reconhecidas como problemas e por que determinados problemas passam a ocupar a agenda governamental. Uma questão (condition) é uma situação social percebida, mas que não demanda, necessariamente, uma resposta estatal. No entanto, quando os formuladores de políticas consideram que ela deve ser cuidada, ela se torna um problema (problem). É de fundamental importância, nesta fase, a percepção destes atores que avaliam três fatores: (i) indicadores; (ii) eventos (focusing events), crises e símbolos; (iii) feedback das ações governamentais.

b) $\quad 2^{\circ}$ fluxo - policy stream: neste momento, são identificadas as alternativas e soluções existentes (policy alternatives), ainda que não relacionadas especificamente a determinados problemas. As alternativas são elaboradas por especialistas (pesquisadores, assessores parlamentares, acadêmicos, funcionários públicos, analistas pertencentes a grupos de interesses, etc.), interessados naquela área específica. Quando alguma solução é reconhecida como viável, ela é difundida e passa a ser encampada pelos diversos atores, ainda que inicialmente com ela não concordassem. O processo é lento e depende do poder de persuasão do interlocutor.

c) $3^{\circ}$ fluxo - politics stream: é a fase da dimensão política propriamente dita, com dinâmica e regras próprias. Aqui, o processo é caracterizado por barganhas e negociações políticas. Três elementos são destacados: (i) o clima ou humor nacional national mood (situação na qual diversas pessoas compartilham as mesmas questões durante um determinado período de tempo) proporciona que determinadas ideias ganhem força e sejam colocadas na agenda; (ii) a influência das forças políticas organizadas, exercida principalmente pelos grupos de pressão, permite avaliar se o ambiente é propício ou não às reformas; (iii) as mudanças dentro do próprio governo - turnover (mudança de funcionários em posições estratégicas, mudança de gestão, etc.) podem desencadear alterações na agenda, quer reforçando, quer retirando determinadas questões da pauta.

Em regra, estes três fluxos (problemas, soluções e dinâmica política) seguem seus cursos de forma independente. No entanto, em algumas circunstâncias raras eles convergem, possibilitando uma oportunidade de mudança na agenda. Segundo Capella, "nesse momento, um problema é reconhecido, uma solução está disponível e as condições políticas tornam o momento propício para a mudança, permitindo a convergência entre os 
três fluxos e permitindo que questões ascendam à agenda". ${ }^{18}$ A essas circunstâncias Kingdon denomina janelas de oportunidades (policy windows), influenciadas especialmente pelo fluxo de problemas e pelo fluxo político. Quando há convergência entre os três fluxos, o denominado coupling (junção dos fluxos), é que se verifica a mudança de agenda. Como dito nas linhas acima, estes momentos são raros e passageiros e a decisão deve ser tomada a tempo, sob pena de fechar as janelas e ter de aguardar uma nova conjunção.

\subsection{A Questão Democrática}

Como decisões políticas, as políticas públicas são tanto mais legítimas quanto mais próximas estiverem da vontade da maioria da coletividade a que são dirigidas. Daí por que estão estritamente relacionadas com a questão democrática, sendo de grande importância a análise acerca do grau e do tipo de participação popular nas decisões políticas.

Também aqui o cerne da discussão é objeto da Ciência Política, embora devam ser buscadas no Direito as normas estabelecendo as formas e em que ocasiões o povo será chamado a participar da tomada de decisões.

De maneira bastante resumida, democracia "designa a forma de governo na qual o poder político é exercido pelo povo" 19 ou "um processo de convivência social em que o poder emana do povo, há de ser exercido direta ou indiretamente pelo povo e em proveito do povo". 20

Povo, no sentido jurídico, "exprime o conjunto de pessoas vinculadas de forma institucional e estável a um determinado ordenamento jurídico, ou, segundo Raneletti, ‘o conjunto de indivíduos que pertencem ao Estado, isto é, o conjunto de cidadãos", ${ }^{21}$

A depender da forma com que o povo exerce o poder político, a democracia é classificada em direta, indireta (ou representativa) ou semidireta.

A democracia direta "é aquela em que o povo exerce, por si, os poderes governamentais, fazendo leis, administrando e julgando, o que é uma reminiscência histórica"22.

\footnotetext{
${ }^{18}$ CAPELLA, Ana Cláudia N. Op. cit., p. 95.

19 BOBBIO, Norberto. Estado, Governo, Sociedade - Para uma teoria geral da política. 14. ed. São Paulo: Paz e Terra, 2007. p. 135.

${ }^{20}$ SILVA, José Afonso da. Poder Constituinte e Poder Popular (estudos sobre a Constituição). 1. ed., 3. tir. São Paulo: Malheiros Editores, 2007. p. 45.

${ }^{21}$ BONAVIDES, Paulo. Ciência Política. 10. ed., 3. tir. São Paulo: Malheiros Editores, 1996. p. 76.

22 SILVA, José Afonso da. Op. cit., 2007, p. 47.
} 
Já a democracia indireta ou representativa "é aquela em que o povo, fonte primária do poder, não podendo dirigir os negócios do Estado diretamente, por si, outorga as funções de governo aos seus representantes, que elege periodicamente". ${ }^{23}$ Democracia representativa, para Norberto Bobbio, "significa genericamente que as deliberações coletivas, isto é, as deliberações que dizem respeito à coletividade inteira, são tomadas não diretamente por aqueles que dela fazem parte mas por pessoas eleitas para esta finalidade" ${ }^{24}$. Para o Autor, são apenas dois os institutos de democracia direta no sentido próprio da palavra: a assembleia dos cidadãos deliberantes sem intermediários e o referendum.

Por fim, democracia semidireta "é, na verdade, democracia representativa, com alguns institutos de participação direta do povo nas funções do governo". ${ }^{25}$

Para alguns, a ideia de democracia direta só é possível nos pequenos Estados. No entanto, a consolidação da democracia representativa não exclui a democracia direta. ${ }^{26}$

No atual estágio da democracia brasileira, a vontade popular se manifesta de duas formas: (i) indireta: através da eleição dos seus representantes no âmbito do Poder

${ }^{23}$ SILVA, José Afonso da. Op. cit., 2007, p. 47.

${ }^{24}$ BOBBIO, Norberto. O futuro da democracia. 10. ed. São Paulo: Paz e Terra, 2006. p. 56.

${ }^{25}$ SILVA, José Afonso da. Op. cit., 2007, p. 47.

${ }^{26}$ De acordo com Bobbio, "A consolidação da democracia representativa, porém, não impediu o retorno à democracia direta, embora sob formas secundárias. Ao contrário, o ideal da democracia direta como a única verdadeira democracia jamais desapareceu, tendo sido mantido em vida por grupos políticos radicais, que sempre tenderam a considerar a democracia representativa não como uma inevitável adaptação do princípio da soberania popular aos grandes Estados, mas como um condenável ou errôneo desvio da ideia originária do governo do povo, pelo povo e através do povo. Como é bem conhecido, Marx acreditou encontrar alguns traços de democracia direta na breve experiência de direção política feita pela Comuna de Paris entre março e abril de 1871. Lênin retomou com força o tema em Estado e revolução (1917), o ensaio que haveria de guiar a mente e a ação dos construtores do novo Estado que estava surgindo das cinzas da autocracia czarista. Frequentemente a democracia direta foi contraposta, como forma própria da futura democracia socialista, à democracia representativa, condenada como forma imperfeita, reduzida e ilusória de democracia, mas, ao mesmo tempo, como a única forma possível de democracia num Estado de classe tal qual o Estado burguês. Sob o nome genérico de democracia direta entendem-se todas as formas de participação no poder, que não se resolvem numa ou noutra forma de representação (nem a representação de interesses gerais ou política, nem a representação dos interesses particulares ou orgânica): a) o governo do povo através de delegados investidos de mandato imperativo e portanto revogável; b) o governo de assembleia, isto é, o governo não só sem representantes irrevogáveis ou fiduciários, mas também sem delegados; c) o referendum. (...) Destas três formas de democracia direta, a segunda e a terceira não podem por si só substituir, e de fato jamais substituíram, as várias formas de democracia representativa praticáveis num Estado democrático, assim como de resto as várias formas de democracia representativa jamais pretenderam substituir, e de fato jamais substituíram, as formas autoritárias do exercício do poder, como são, por exemplo, em todos os Estados que mesmo assim são chamados de democráticos, as formas próprias do aparato burocrático. Portanto, não podem por si sós constituir uma verdadeira alternativa ao Estado representativo: a segunda porque é aplicável apenas nas pequenas comunidades, a terceira porque é aplicável apenas em circunstâncias excepcionais e de particular relevo. Quanto à primeira, com a formação dos grandes partidos organizados que impõem uma disciplina de voto, às vezes férrea, aos representantes eleitos em suas listas, a diferença entre representação com mandato e representação sem mandato torna-se cada vez mais evanescente. O deputado eleito através da organização do partido torna-se um mandatário, senão dos eleitores, ao menos do partido, que o penaliza retirando-lhe a confiança toda vez que ele se subtrai à disciplina, a qual converte-se assim num sucedâneo funcional do mandato imperativo por parte dos eleitores" (Op. cit., 2007, p. 154-155). 
Executivo e Legislativo; (ii) direta: através da participação nos Conselhos, por meio do plebiscito, referendo e participação popular.

Não obstante a figura dos conselhos (ainda que com outras denominações) não seja uma inovação da Constituição Federal de $1988^{27} /^{28}$, o fato é que a Carta Constitucional deu novos e importantes contornos a estes órgãos.

Patrícia Mazza Arzabe destaca a figura dos conselhos nos seguintes termos:

É no âmbito dos conselhos de políticas públicas, também denominados conselhos de direitos ou conselhos gestores de políticas setoriais, que a participação institucionalizada é mais marcante.

Esses conselhos são órgãos colegiados, permanentes e deliberativos, legalmente incumbidos da formulação, supervisão e avaliação das políticas públicas, em cada uma das esferas de governo.

(...) Os conselhos de políticas públicas vêm constituir o que Vera Silva Telles reconhece como uma nova institucionalidade pública e democrática no país. Trata-se de fato de uma nova institucionalidade da perspectiva de sua constituição, no sentido de configurar um arranjo institucional com feições novas, porque eles não são meramente comunitários - são distintos dos fóruns congregadores de entidades e associações da sociedade civil - e não são meramente estatais. Sua novidade é ainda mais significativa pelo caráter compartilhado na formulação, gestão, controle e avaliação das políticas públicas. Esta participação com igualdade de poderes é inteiramente nova para o Estado, em especial para a Administração Pública, habituada à centralização das decisões e pelo uso deslocado do argumento do poder discricionário mesmo em matéria de direitos humanos, especialmente de direitos sociais. Em suma, ela é transformadora da democracia representativa. ${ }^{29}$

Os conselhos gestores têm o potencial de transformar a democracia representativa, aumentando qualitativamente a participação popular na tomada das decisões políticas importantes. Este potencial, no entanto, pode não florescer e os conselhos tornarem-se meras instituições burocráticas, formadas por representantes dos grupos dominantes com o objetivo único de se perpetuar naquela situação, alimentando-se da máquina estatal e sem qualquer preocupação concreta com o cumprimento de sua missão constitucional.

27 De acordo com Maria da Glória Gohn, "No Brasil, houve experiências históricas como conselhos comunitários nos anos 60 e no final dos anos 70, ainda na fase do regime militar, ou os "conselhos de notáveis" que atuavam junto às instâncias governamentais. Nos anos 80 os conselhos populares foram a novidade no cenário político. Nos anos 90 , foram criados os conselhos gestores interinstitucionais, previstos a partir da Constituição de 88" (Os Conselhos de Educação e a Reforma do Estado. In CARVALHO, Maria do Carmo A. A.; TEIXEIRA, Ana Cláudia C. (orgs.). Conselhos Gestores de Políticas Públicas. São Paulo: Polis, 2000. p. 35).

${ }^{28}$ Os Conselhos - de Trabalhadores e Econômicos - foram expressamente previstos pela Constituição de Weimar (artigo 165), com o objetivo de conciliar os interesses dos capitalistas e dos trabalhadores. Para alguns estudiosos, representavam "o pensamento mais original da Constituição" (Hermann Heller apud BERCOVICI, Gilberto. Constituição e Estado de exceção permanente: atualidade de Weimar. Rio de Janeiro: Azougue Editorial, 2004. p. 48).

${ }^{29} \mathbf{O}$ direito à proteção contra a pobreza e a exclusão social. Tese de doutorado, apresentada no ano de 2001, na Universidade de São Paulo - Faculdade de Direito, p. 177-178. 
Apesar de já terem passado mais de duas décadas desde a promulgação da Constituição Federal de 1988, o fato é que a atuação dos Conselhos e a influência de suas deliberações nas decisões políticas importantes ainda se mostram bastante tímidas, não tendo conseguido, até o presente momento, despertar na sociedade o real desejo de participar da vida política do país.

Vivemos um momento de crise da democracia, fruto do individualismo característico da era capitalista, de tal forma que as matérias de ordem pública se mostram distantes e sem qualquer relação com o dia a dia de cada um. ${ }^{30}$

Existe, atualmente, uma enorme dificuldade dos cidadãos em reconhecer as questões públicas, já que o público foi colonizado pelo privado. Segundo Bauman,

\begin{abstract}
"o interesse público" é reduzido curiosidade a respeito das vidas privadas das figuras públicas, limitando a arte da vida pública à exposição pública dos casos privados e das confissões públicas de sentimentos privados (quanto mais íntimos melhor). As "questões públicas" que resistem a tal redução se tornam incompreensíveis. ${ }^{31}$
\end{abstract}

No mundo de hoje, o indivíduo é inimigo do cidadão. ${ }^{32}$

É preciso "regressar aos cidadãos", tomar a sério os cidadãos difíceis, como alerta o Professor José Joaquim Gomes Canotilho:

\begin{abstract}
(...) A nosso ver, as transformações da política só são visíveis se levarem a sério os cidadãos difíceis. Escola, cidade, território, universidade, estado, democracia, nenhum destes lugares clássicos da civilidade e da política (civilis/polis) é hoje politicamente simpático. E demoramos a compreender porque é que o cidadão ao confrontar-se com as ideias, os interesses e as instituições da vida política se transforma ele próprio em cidadão difícil. As manifestações de cidadania difícil dinamizada por cidadãos difíceis estão aí: rejeição da política, desconfiança relativamente às instituições, aceitação de paradigmas da antipolítica. Em instituições difíceis e com cidadãos difíceis também o pensamento é difícil, sobretudo num mundo em que a "democracia parlante" e a "democracia dançante" procuram o jogo das imagens em desfavor de qualquer suspensão reflexiva. (...) O Estado Social é difícil. Aquilo que foi outrora um esquema organizatório de milagres - com as suas escolas públicas, os seus serviços sociais, as políticas de pleno emprego e a redistribuição de rendimentos através
\end{abstract}

\footnotetext{
${ }^{30}$ De acordo com Nelson Rodrigues dos Santos, "todos os estudos e estimativas deduzem que a sociedade brasileira organizada não representa mais que $15 \%$ da população do país. Ou seja, $85 \%$ da população brasileira é sociedade desorganizada. É um dado comparativo importante, pois, por mais urbanizada que seja nossa população e por mais que tenham crescido nossos movimentos sociais, é uma porcentagem baixa comparada com sociedades mais desenvolvidas. Na Europa, por exemplo, $80 \%$ ou mais da população está ligada a uma forma de organização" (Implantação e funcionamento dos Conselhos de Saúde no Brasil. In CARVAlHO, Maria do Carmo A. A.; TEIXEIRA, Ana Cláudia C. (orgs.). Conselhos Gestores de Políticas Públicas. São Paulo: Pólis, 2000. p. 20).

${ }^{31}$ BAUMAN, Zygmunt. A sociedade individualizada: vidas contadas e histórias vividas. Rio de Janeiro: Jorge Zahar Editor, 2008. p. 68.

${ }^{32}$ Idem, ibidem, p. 140.
} 
de impostos - confronta-se hoje com as crises da socialidade. Não tem dinheiro para o "déficit spending”, não sabe como sustentar as políticas sociais, privatiza serviços públicos, racionaliza os esquemas da administração pública. A democracia é difícil. A democracia representativa passou para "democracia delegativa". Juntamente com as "sondagens de opinião" os fóruns televisivos de prós e contras furtam-se à participação activa e a práticas deliberativas sustentadas. No meio de tudo isto há pessoas, há normas, há valores. Muitas das dificuldades conduzem também ao silencio do cidadão e do profano. Silêncio que deve ser quebrado, desde logo, pela possibilidade dos diversos atores interessados e incomodados demonstrarem a pertinência das diferentes perspectivas contextuais. ${ }^{33}$

A discussão acerca do grau de democracia (previsto e realizado) tem estrita relação com o objeto do presente estudo, pois a edição de políticas públicas em desconformidade com a vontade dos cidadãos aos quais se aplicam acaba por aumentar a litigiosidade e transferir ao Poder Judiciário a tarefa de resolvê-la. Em regra, o debate acaba se concentrando, apenas e tão somente, nas questões jurídicas envolvidas e o Poder Judiciário se transformando, na maioria das vezes, no grande vilão da história, de um lado ou de outro, pela visibilidade decorrente de sua intervenção.

Não pretendemos com tal afirmação sugerir a redução do âmbito de atuação judicial, mas destacar que é defeso ao Poder Judiciário discutir todas as questões envolvidas nas políticas públicas, detendo-se somente aos aspectos jurídicos. As demais discussões não devem ser descuidadas e apenas uma maior participação dos cidadãos na vida política, especialmente na tomada das decisões importantes, dará cabo ao problema ou pelo menos o reduzirá.

Para Maria Paula Dallari Bucci,

\begin{abstract}
cria-se uma sobrecarga de expectativas em relação às reais possibilidades da enunciação constitucional dos direitos, em detrimento das condicionantes também constitucionais - ligadas ao processo político, às estruturas regionais do poder, à permanência das condições de exercício das forças econômicas dominantes etc. $^{34}$
\end{abstract}

Desta forma, não basta uma abundância de leis e uma abundância de ações judiciais a discuti-las; é necessário cuidar da fase anterior à promulgação do ato legislativo: o

33 CANOTILHO, Joaquim José Gomes. Tomemos a sério os cidadãos difíceis. In BENEVIDES, Maria Victoria de Mesquita; BERCOVICI, Gilberto; MELO, Claudineu de. Direitos Humanos, Democracia e República - Homenagem a Fábio Konder Comparato. São Paulo: Quartier Latin, 2009. p. 593-594.

${ }^{34}$ Destaca a Autora que "o exercício do poder político entre nós está muito longe de um padrão racional, apreensível pelo direito. A política brasileira, dizia um professor de direito familiarizado com o ambiente parlamentar, está mais perto de ser explicada pela antropologia, com seus conhecimentos sobre tribos, clãs e famílias no poder" (BUCCI, Maria Paula Dallari. Controle Judicial de Políticas Públicas: Possibilidades e Limites. In BENEVIDES, Maria Victoria de Mesquita; BERCOVICI, Gilberto; MELO, Claudineu de. Direitos Humanos, Democracia e República - Homenagem a Fábio Konder Comparato. São Paulo: Quartier Latin, 2009. p. 695 e 697). 
momento da deliberação, direta (através da participação nos conselhos, da realização de plebiscito e referendo e da iniciativa popular $^{35}$ ) e indireta (através da eleição e fiscalização dos representantes junto aos Poderes Legislativo e Executivo).

É preciso, mais que tudo, resgatar a vida em sociedade, despertar a responsabilidade de cada um com o todo, quebrando as barreiras da individualidade e descobrindo (ou redescobrindo) a satisfação de participar da construção do bem-estar social.

Estas reflexões muito importam ao estudo das políticas públicas, pois exigem que os olhares se voltem não apenas para os efeitos (descontentamento com as políticas públicas que não refletem os verdadeiros valores e anseios da coletividade e aumento da litigiosidade), mas especialmente para as causas do fenômeno (falta de interesse e participação popular na gestão da coisa pública).

Desta forma, embora não iremos tratar, ao longo deste trabalho, da efetiva participação popular - por meio dos Conselhos - na formulação e controle das políticas públicas previdenciárias, não descuidamos da sua importância especialmente para que se estabeleçam as fronteiras do controle judicial de forma que se respeitem os atos praticados nas outras esferas. ${ }^{36}$

Até aqui, nossa abordagem cuidou de buscar na Ciência Política os elementos necessários para a fixação do conceito de políticas públicas.

Frise-se que para os fins deste trabalho a expressão políticas públicas será utilizada em sua dupla conotação (política de Estado e política de Governo), já que a análise de

\footnotetext{
${ }^{35}$ Vide artigo 14, incisos I, II e III da CFR.

${ }^{36}$ No âmbito da Previdência Social, o artigo 194, parágrafo único, inciso VII foi regulamentado pela Lei ${ }^{\circ}$ 8.213/91, que criou o Conselho Nacional de Previdência Social. Os Conselhos de Previdência Social, por sua vez, foram instituídos pelo Decreto ${ }^{\circ}$ 4.874/2003. A Lei $n^{\circ} 8.213 / 91$, em seu artigo $3^{\circ}$, criou o Conselho Nacional de Previdência Social (CNPS), formado por representantes do Governo Federal e da sociedade civil (representantes dos aposentados e pensionistas, representantes dos trabalhadores em atividade $\mathrm{e}$ representantes dos empregadores), cujas decisões têm caráter deliberativo. Seus membros têm mandato de dois anos, prorrogável por igual período, e possuem estabilidade no emprego, da nomeação até um ano após o término do mandato de representação, somente podendo ser demitidos por motivo de falta grave, regularmente comprovada através de processo judicial. Suas atribuições estão expressamente indicadas no artigo $4^{\circ}$ da Lei $n^{\circ} 8.213 / 91$, destacando-se, especialmente, a função de deliberar sobre a política de Previdência Social e sobre a gestão do sistema previdenciário.

O Decreto $\mathrm{n}^{\circ} 4.874$, de 11 de novembro de 2003, instituiu como unidades descentralizadas do Conselho Nacional de Previdência Social (CNPS) os Conselhos de Previdência Social (CPS). Suas funções estão inscritas no artigo 296-A do Decreto $n^{\circ}$ 3.048/99, com a redação dada pelo Decreto $n^{\circ}$ 5.699/2006. Tais órgãos são subordinados ao CNPS e vinculados às Gerências Executivas do INSS. Não são mais órgãos estaduais ou municipais e estão organizados de acordo com a estrutura do INSS. Atualmente, o INSS possui (5) cinco Gerências Regionais, localizadas nas cidades de Belo Horizonte, Brasília, Recife, Santa Catarina e São Paulo. Estas, por sua vez, abrangem 100 (cem) Gerências Executivas e 1.107 (um mil, cento e sete) agências da Previdência Social. Em regra, cada Gerência Executiva possui um Conselho de Previdência Social na sua estrutura, com exceção da cidade do Rio de Janeiro e São Paulo. Ao todo, existem 96 (noventa e seis) Conselhos de Previdência Social. As manifestações dos CPS têm natureza consultiva.
} 
qualquer política de Governo (política pública em sentido estrito) pelo Poder Judiciário está centrada, essencialmente, na sua pertinência com a política de Estado e na preservação, por parte de uma e de outra, do direito fundamental que se pretende concretizar.

Estabelecida tal premissa, já é possível adentrar na órbita jurídica a fim de estabelecer qual a política de Estado desenhada em matéria previdenciária que deve dar suporte às políticas de Governo necessárias a concretizá-la.

O primeiro passo, assim, é definir o que é o conteúdo do direito fundamental à previdência social.

\subsection{Direitos Fundamentais Sociais}

Fundamentais são os direitos relativos ao ser humano, reconhecidos e positivados na Constituição, distinguindo-os, assim, dos direitos do homem, relacionados às posições jurídicas que se reconhecem ao ser humano como tal, independentemente de sua vinculação com determinada ordem constitucional, e que, portanto, aspiram à validade universal, para todos os povos e tempos, de tal sorte que revelam um inequívoco caráter supranacional (internacional). ${ }^{37}$

São também fundamentais os direitos inscritos em tratados internacionais de que o Brasil faça parte, como determina o $\S 2^{\circ}$ do artigo $5^{\circ}$ da Constituição Federal.

Para os fins deste trabalho, optamos por utilizar a expressão direitos fundamentais, buscando nas normas constitucionais os seus contornos, a partir dos quais serão analisadas as políticas públicas editadas com o fim de concretizá-los.

Os direitos fundamentais constituem a base e o fundamento do Estado Democrático de Direito e, como resultado da personalização e positivação constitucional de determinados valores básicos, integram o núcleo substancial da ordem normativa. ${ }^{38}$

A atual concepção de direitos fundamentais - quer em relação ao seu conteúdo, quer quanto à sua titularidade, eficácia e efetivação - é fruto de uma longa evolução histórica, retratada pela doutrina como "gerações" ou "dimensões" de direitos.

\footnotetext{
${ }^{37}$ SARLET, Ingo. A eficácia dos direitos fundamentais. 9. ed., rev., atual. e ampl. Porto Alegre: Livraria do Advogado Editora, 2007b. p. 35-36. No mesmo sentido é a distinção apresentada por Canotilho (2003, p. 393): "direitos do homem são direitos válidos para todos os povos e em todos os tempos (dimensão jusnaturalista-universalista); direitos fundamentais são os direitos do homem, jurídico-institucionalmente garantidos e limitados espacio-temporalmente" (grifos do Autor).

${ }^{38}$ SARLET, Ingo. Op. cit., 2007b, p. 70.
} 
O termo "dimensões", utilizado pelo Professor Ingo Sarlet ${ }^{39}$, será aqui por nós adotado na medida em que retrata o processo de cumulação ocorrido, incorporando-se às garantias já existentes as novas conquistas.

Em apertada síntese, os direitos de primeira dimensão ou direitos de liberdade correspondem aos direitos civis e políticos e possuem uma matriz manifestamente liberal, frutos do pensamento liberal-burguês do século XVIII. São os direitos individuais ante o Estado, direitos de defesa no sentido de não intervenção estatal em relação à autonomia individual.

Os direitos de segunda dimensão, denominados direitos sociais, econômicos e culturais são aqueles relacionados ao bem-estar da coletividade, como o direito à educação, saúde, previdência, trabalho. Estão relacionados aos fenômenos ocorridos no final do século XIX (graves problemas sociais e econômicos gerados pela industrialização), ensejando uma efetiva participação estatal na realização da justiça social. Por tal razão, possuem um cunho predominantemente positivo, ou seja, são direitos a prestações estatais. $^{40}$

Os direitos de terceira dimensão, por fim, têm como fundamento a solidariedade e a fraternidade e se referem a bens e interesses sem titularidade definida, como o meio ambiente saudável, a paz, o desenvolvimento, entre outros. Destacaram-se, sobretudo, após o término da $2^{\text {a }}$ Guerra Mundial e resultam de

novas reivindicações fundamentais do ser humano, geradas, dentre outros fatores, pelo impacto tecnológico, pelo estado crônico de beligerância, bem como pelo processo de descolonização do segundo pós-guerra e suas contundentes consequências, acarretando profundos reflexos na esfera dos direitos fundamentais. ${ }^{41}$

Alguns doutrinadores, como o Professor Paulo Bonavides, ainda vislumbram a existência de uma quarta dimensão de direitos fundamentais (direito à democracia direta, à informação e ao pluralismo).

O processo cumulativo a que nos referimos nas linhas acima confere aos direitos fundamentais o conteúdo das várias dimensões, englobando os direitos individuais, sociais

\footnotetext{
${ }^{39}$ Op. cit., 2007 b, p. 60.

${ }^{40}$ Embora os direitos sociais se caracterizem por demandar uma atuação estatal positiva, é certo que em alguns casos exigem do Estado um não fazer, nas hipóteses das "liberdades sociais", como a liberdade de sindicalização, o direito de greve, etc. (SARLET, Ingo. Op. cit., 2007b, p. 55).

${ }^{41}$ Op. cit., 2007 b, p. 56.
} 
e de natureza coletiva, incorporando as demais dimensões que vão sendo consolidadas de tempos em tempos.

\subsubsection{A justiciabilidade dos Direitos Fundamentais Sociais}

Os direitos sociais possuem dupla dimensão: a dimensão objetiva e a dimensão subjetiva. $^{42}$

A dimensão objetiva revela quais são as decisões valorativas de natureza jurídicoobjetiva inscritas no texto constitucional, com eficácia em todo ordenamento jurídico e que fornecem diretrizes para os Poderes Legislativo, Executivo e Judiciário. Também representa "uma espécie de mais-valia jurídica, no sentido de reforço da juridicidade das normas de direitos fundamentais". ${ }^{43}$ Por traduzir as opções axiológicas feitas pela coletividade, a todos vincula, sendo possível falar de uma responsabilidade comunitária dos indivíduos. ${ }^{44}$

A dimensão subjetiva possibilita que o titular do direito fundamental exija seu interesse juridicamente tutelado em face de quem deve prestá-lo. Nossa tradição jurídica, estruturada em bases liberais, ainda resiste em reconhecer o caráter subjetivo dos direitos fundamentais sociais. Admite-se, sem grandes controvérsias, o efeito impeditivo de criação de normas infraconstitucionais em desacordo com os postulados constitucionais. Para além deste ponto, iniciam-se as mais variadas discussões doutrinárias e jurisprudenciais, restando em aberto quais as soluções cabíveis na hipótese de não efetivação do direito social pelo órgão competente. Em outros termos: qual a garantia assegurada ao titular do direito ante a não edição da política pública necessária a concretizá-lo?

Os Direitos Fundamentais Sociais não são direitos contra o Estado, mas sim direitos através do Estado, exigindo do poder público certas prestações materiais. São os Direitos Fundamentais do homem-social dentro de um modelo de Estado que tende cada vez mais a ser social, dando prevalência aos interesses coletivos antes que aos individuais. O Estado, mediante leis parlamentares, atos administrativos e a criação real de instalações de serviços públicos, deve definir, executar e implementar, conforme as circunstâncias, as chamadas "políticas públicas" (de educação, saúde, assistência, previdência, trabalho, educação) que facilitem o gozo dos direitos constitucionalmente protegidos. ${ }^{45}$

\footnotetext{
${ }^{42}$ O Professor Ingo Sarlet utiliza o termo perspectiva ao invés de dimensão (Op. cit., 2007b, p. 158, nota de rodapé 397).

${ }^{43}$ SARLET, Ingo. Op. cit., 2007b, p. 160.

${ }^{44}$ Ibidem, p. 162.

${ }^{45}$ KRELL, Andreas J. Direitos sociais e controle judicial no Brasil e na Alemanha: os (des)caminhos de um direito constitucional 'comparado'. Porto Alegre: Sérgio Antonio Fabris Editor, 2002. p. 19-20.
} 
Os direitos fundamentais sociais não são políticas públicas, mas se realizam através delas, quando sua efetivação não puder ser extraída diretamente do texto constitucional. De acordo com Maria Paula Dallari Bucci,

os direitos sociais não são políticas públicas nem devem ser confundidos com elas. São direitos fundamentais, cuja satisfação integral requer programas, recursos públicos, os quais, em circunstâncias de escassez, são alocados segundo a dinâmica política, que combina tempo e definição de prioridades. ${ }^{46}$

Desde logo, é importante ressaltar que a Constituição Federal brasileira de 1988 outorga o mesmo tratamento aos direitos fundamentais individuais e sociais, na medida em que não contém qualquer cláusula restritiva em relação a qualquer deles. ${ }^{47}$ Conclui-se, daí, que a norma inscrita no $\S 1^{\circ}$ do artigo $5^{\circ}$ da Constituição Federal (As normas definidoras dos direitos e garantias fundamentais têm aplicação imediata) é aplicável aos direitos individuais e sociais, vez que fundamentais. Portanto, em um e outro caso, a mesma ênfase conferida à categoria dos direitos deve ser dada - em igual dimensão - à categoria dos deveres, já que a todo direito corresponde uma ação que o assegura, nos termos do artigo 75 do Código Civil.

É porque a Constituição previu determinados direitos como fundamentais, atribuindo obrigações ao Estado e aos particulares (como é o caso dos direitos fundamentais sociais dos trabalhadores) que eles são exigíveis judicialmente, e portanto, corresponderiam a direitos subjetivos. A exigibilidade não é condição de existência do direito, ele não existe porque é exigível. Ele existe, razão pela qual deve ser exigível. ${ }^{48}$

Se assim é, a obrigação em efetivar o direito é a regra e o seu descumprimento só pode ser aceito desde que devidamente justificado, pois imposto por norma constitucional.

\footnotetext{
${ }^{46}$ BUCCI, Maria Paula Dallari. Controle Judicial de Políticas Públicas: Possibilidades e Limites. In Op. cit., p. 702 .

47 Tal distinção é feita pela Constituição de Portugal de 1976, com as revisões constitucionais ocorridas posteriormente, sobretudo a de 1982. Segundo Sarlet (Op. cit., 2007b, p. 177-178), "os direitos fundamentais podem ser divididos em dois grandes grupos formados, respectivamente, pelos direitos, liberdades e garantias (Título II), e pelos direitos econômicos, sociais e culturais (Título III). Tal classificação se justifica pelo fato de o Constituinte ter previsto regimes jurídicos diferenciados para ambos os grupos, reservando uma força jurídica privilegiada aos direitos, liberdades e garantias, que, ao contrário dos direitos sociais, foram incluídos nas "cláusulas pétreas" da Constituição (art. 288, letra $d$, da CRP), além de serem considerados diretamente aplicáveis, vinculando todas as entidades públicas e privadas (art. 18, $\mathrm{n}^{\circ} 1$, da CRP), princípio que não se aplica aos direitos sociais do Título III".

${ }^{48}$ OLSEN, Ana Carolina Lopes. Direitos Fundamentais Sociais: Efetividade frente à reserva do possível. Curitiba: Juruá Editora, 2008. p. 96.
} 
Os direitos, como ressalta Ingo Sarlet, "não podem ter uma existência pautada pela desconsideração recíproca". ${ }^{49}$

Buscamos responder a questão com amparo na teoria elaborada por Robert Alexy, que mais guarda pertinência com o entendimento aqui adotado. ${ }^{50}$

Alexy classifica os direitos subjetivos de acordo com as posições que o seu titular ocupa: (i) direitos a algo; (ii) liberdades e (iii) competências. ${ }^{51}$

Os direitos a algo se dividem em direitos de defesa (direitos a ações negativas) e direitos a prestações (direitos a ações positivas).

Os direitos de defesa subdividem-se em três tipos:

\begin{abstract}
o primeiro grupo é composto por direitos a que o Estado não impeça ou não dificulte determinadas ações do titular do direito; o segundo grupo, de direitos a que o Estado não afete determinadas características ou situações do titular do direito; o terceiro grupo, de direitos a que o Estado não elimine determinadas posições jurídicas do titular do direito. ${ }^{52}$
\end{abstract}

Já os direitos a prestações tanto podem se referir a uma ação fática estatal (direitos a prestações em sentido estrito) como a uma ação normativa (direitos a prestações em sentido amplo). Ressalta Alexy que em muitos casos de direitos fundamentais sociais, "há um feixe de posições que dizem respeito em parte a prestações fáticas e em parte a prestações normativas" ${ }^{, 53}$, motivo pelo qual o termo deve englobar as duas perspectivas. Em suas palavras:

Em virtude de normas de direitos fundamentais, todos encontram-se em posições de direitos a prestações que são, do ponto de vista do direito constitucional, tão importantes que a decisão sobre elas não possa ser simplesmente deixada para a maioria parlamentar simples. ${ }^{54}$

\footnotetext{
${ }^{49}$ SARLET, Ingo. Op. cit., 2007b, p. 240.

${ }^{50}$ Concordamos com Ingo Sarlet ao afirmar que a classificação não deve ser supervalorizada, quer pela diversidade de funções exercidas pelos direitos fundamentais, quer pelas especificidades de cada ordem constitucional. De toda forma, ela é importante para a teoria dos direitos fundamentais, na medida em que fornece uma visão global e sistemática sobre o conjunto dos direitos fundamentais e parâmetros objetivos para sua interpretação, enquadramento funcional e até mesmo a determinação do regime jurídico aplicável (SARLET, Ingo. Op. cit., 2007b, p. 176).

${ }^{51}$ Não iremos abordar as questões relativas às liberdades e competências, vez que não relacionadas diretamente ao objeto deste trabalho. Por certo que a discussão acerca das políticas públicas a serem editadas para a concretização dos direitos fundamentais abrange o tema da competência, mas não se mostra necessário maior aprofundamento já que o pressuposto adotado é que o órgão público competente, de acordo com as regras estruturais, não agiu ou agiu mal.

${ }^{52}$ ALEXY, Robert. Teoria dos Direitos Fundamentais. São Paulo: Malheiros Editores, 2008. p. 196. Grifos do Autor.

${ }^{53}$ Ibidem, p. 442-443.

${ }^{54}$ Idem, ibidem, p. 450.
} 
Os direitos a prestações em sentido amplo englobam os direitos a proteção, os direitos a organização e procedimento e os direitos a prestações em sentido estrito.

Interessa-nos, aqui, a categoria dos direitos a prestações em sentido estrito, definidos por Alexy como os "direitos do indivíduo, em face do Estado, a algo que o indivíduo, se dispusesse de meios financeiros suficientes e se houvesse uma oferta suficiente no mercado, poderia também obter de particulares". ${ }^{55}$ É o caso do direito fundamental à previdência social. ${ }^{56}$

Os custos envolvidos na realização destas prestações estatais são usualmente invocados para sustentar a tese da impossibilidade do cumprimento da obrigação pelo órgão público responsável, impondo verificar se a ordem jurídica comporta tal restrição.

\subsubsection{Restrições}

Atualmente é assente na doutrina a noção de que tanto os direitos individuais como os direitos sociais acarretam custos, na medida em que também a garantia dos direitos de liberdade e dos direitos de defesa exigem do Estado medidas que implicam "alocação significativa de recursos materiais e humanos para a sua proteção e implementação" ${ }^{, 57}$. É certo, contudo, que os direitos sociais a prestações, em alguns casos, podem impor maiores despesas ao órgão estatal. ${ }^{58}$

Para saber em que medida os custos podem ou não impedir a concretização dos direitos fundamentais, é necessário esclarecer duas questões: (i) se os direitos fundamentais são absolutos; e (ii) em caso negativo, em que circunstâncias são admitidas restrições.

Sem querer antecipar a análise que será feita no Capítulo 2 (subitem 2.5.3.1), entendemos que as normas de direito fundamental se revelam por meio de princípios e regras, nos termos da teoria formulada por Alexy. Sendo os princípios mandamentos de otimização, que podem ser satisfeitos em graus variados, de acordo com o caso concreto,

\footnotetext{
${ }^{55}$ Ibidem, p. 499.

${ }^{56}$ Embora Alexy tenha apresentado como exemplos os direitos à assistência, saúde, trabalho, moradia e educação, entendemos que o direito à previdência também faz parte desta relação, especialmente no caso brasileiro, em que assistência, previdência e saúde constituem o sistema de Seguridade Social.

${ }^{57}$ SARLET, Ingo. Op. cit., 2007b, p. 305.

${ }^{58}$ Ingo Sarlet $(2007 \mathrm{~b}$, p. 305) cita corrente doutrinária que vislumbra a existência de direitos sociais a prestações economicamente neutras (que não implicam a alocação de recursos para sua implementação), no sentido de que há prestações materiais condicionadas ao pagamento de taxas e tarifas públicas, além de outras que se restringem ao acesso aos recursos já disponíveis. Para Sarlet, no entanto, mesmo nestas situações há uma repercussão econômica ao menos indireta, vez que até o já disponível resultou da alocação e aplicação de recursos (materiais, humanos ou financeiros) oriundos, em regra, da receita tributária e outras formas de arrecadação do Estado.
} 
dentro das possibilidades jurídicas e fáticas existentes, resta claro que eles não possuem natureza absoluta; se assim fosse eles não poderiam ser cotejados com outros, revestindo então a natureza de regras. ${ }^{59}$

Partindo da premissa de que os direitos fundamentais não são absolutos, cabe verificar de que formas podem ser restringidos.

Duas teorias se propõem a explicar a hipótese.

A teoria externa vislumbra a existência do direito e sua restrição, duas coisas distintas que guardam uma relação de restrição. Ou seja: "há, em primeiro lugar, o direito em si, não restringido, e, em segundo lugar, aquilo que resta do direito após a ocorrência de uma restrição, o direito restringido. ${ }^{60}$

A teoria interna, por sua vez, identifica na mesma figura o direito com um determinado conteúdo, substituindo o conceito de restrição pelo conceito de limite. Desta forma, "dúvidas acerca dos limites do direito não são dúvidas sobre quão extensa pode ser sua restrição, mas dúvidas sobre seu conteúdo. Quando eventualmente se fala em 'restrições' no lugar de 'limites', então se fala em 'restrições imanentes'”. 61

Apenas a teoria externa é compatível com a adoção do modelo de regras e princípios, característico da Constituição Federal de 1988, donde se conclui que as restrições não integram o núcleo do direito fundamental e são admitidas no ordenamento jurídico. De acordo com Alexy, "são normas que restringem uma posição prima facie de direito fundamental". ${ }^{62} \mathrm{~A}$ admissão das restrições exige que elas sejam compatíveis com a Constituição.

Tanto as regras como os princípios podem conter restrições a direitos fundamentais.

Segundo Alexy, "uma regra (compatível com a Constituição) é uma restrição a um direito fundamental se, com sua vigência, no lugar de uma liberdade prima facie ou de um

\footnotetext{
${ }^{59}$ Segundo Alexy (Op. cit., p. 111), "é fácil argumentar contra a existência de princípios absolutos em um ordenamento jurídico que inclua direitos fundamentais. Princípios podem se referir a interesses coletivos ou a direitos individuais. Se um princípio se refere a interesses coletivos e é absoluto, as normas de direitos fundamentais não podem estabelecer limites jurídicos a ele. Assim, até onde o princípio absoluto alcançar, não pode haver direitos fundamentais. Se o princípio absoluto garante direitos individuais, a ausência de limites desse princípio levaria à seguinte situação contraditória: em caso de colisão, os direitos de cada indivíduo, fundamentados pelo princípio absoluto, teriam que ceder em favor dos direitos de todos os indivíduos, também fundamentados pelo princípio absoluto. Diante disso, ou os princípios absolutos não são compatíveis com direitos individuais, ou os direitos individuais que sejam fundamentados pelos princípios absolutos não podem ser garantidos a mais de um sujeito de direito."

${ }^{60}$ ALEXY, Robert. Op. cit., p. 277. Itálico do Autor.

${ }^{61}$ ALEXY, Robert. Op. cit., p. 278.

${ }^{62}$ Ibidem, p. 281.
} 
direito fundamental prima facie, surge uma não liberdade definitiva ou um não direito definitivo de igual conteúdo". 63

Já os princípios restringidores não são suficientes, por si só, para colocar o indivíduo em determinadas posições definitivamente restringidas. Para tanto, "é necessário um sopesamento entre o princípio constitucional atingido e o(s) princípio(s) que o restringe(m)". ${ }^{64}$ Conclui Alexy que "um princípio é uma restrição a um direito fundamental se há casos em que ele é uma razão para que, no lugar de uma liberdade fundamental prima facie ou de um direito fundamental prima facie, surja uma não liberdade definitiva ou um não direito definitivo de igual conteúdo" ${ }^{65}$

A questão do sopesamento dos princípios será abordada no Capítulo 2, por se constituir na técnica utilizada pelo Poder Judiciário para realizar o controle das políticas públicas em face do direito fundamental.

O que importa por ora registrar é a possibilidade de o direito fundamental ser restringido.

\subsection{O Direito Fundamental à Previdência Social e as políticas públicas previdenciárias}

A Previdência Social é um dos pilares do Sistema de Seguridade Social, ao lado da Saúde e da Assistência Social (artigo 194 da CFR).

A evolução histórica da Seguridade Social no Brasil demonstra que tal distinção nem sempre foi tão clara e apenas a partir da Constituição Federal de 1988 é que a questão restou devidamente assentada, estabelecendo-se textualmente normas comuns à Previdência, Assistência e Saúde, além das normas específicas de cada ramo.

O grande passo dado em 1988 foi a consagração expressa do direito à previdência social (assim como dos demais direitos sociais previstos no artigo $6^{\circ}$, caput, da CFR) como direito fundamental. ${ }^{66}$

\footnotetext{
${ }^{63}$ Ibidem, p. 283. O Autor cita como exemplo o caso dos motociclistas que, enquanto não existir o dever de usar capacete, têm uma liberdade fundamental prima facie para usar ou não o capacete. A partir do momento em que a restrição surgir, os motociclistas não terão mais uma liberdade prima facie, mas uma não liberdade definitiva de igual conteúdo.

${ }^{64}$ Idem, ibidem, p. 284.

${ }^{65}$ Idem, p. 284-285. Itálico do Autor.

${ }^{66}$ De acordo com Ingo Sarlet (Op. cit., 2007b, p. 77), “a própria utilização da terminologia 'direitos e garantias fundamentais' constitui novidade, já que nas Constituições anteriores costumava utilizar-se a denominação 'direitos e garantias individuais', desde muito superada e manifestamente anacrônica, além de desafinada em relação à evolução recente no âmbito do direito constitucional e internacional. A acolhida dos direitos fundamentais sociais em capítulo próprio no catálogo dos direitos fundamentais ressalta, por sua vez,
} 


\subsubsection{Uma breve análise histórica}

Antes de adentrar na análise do sistema brasileiro, breves anotações se fazem necessárias acerca dos principais fatos ocorridos mundo afora e que de alguma forma influenciaram o modelo aqui concebido.

A definição de um marco temporal inicial da Seguridade Social não é possível, dada a existência de normas esparsas dispondo sobre a proteção social desde a Antiguidade, embora sem os contornos suficientes a caracterizar o sistema de seguridade social, fato apenas ocorrido em 1942, com a implantação do Plano Beveridge, na Inglaterra. $^{67}$

O regramento anterior mesclava categorias da previdência e da assistência, ora atribuindo à Igreja, ora ao Estado, ora aos empregadores, a obrigação de prestar o socorro. Cite-se, a propósito, a assistência aos pobres na Idade Média (estabelecida por Carlos Magno), as cooperativas criadas por Robert Owen, o Poor Law Act (1601), a criação da Cooperativa dos Probos Pioneiros de Rochdale em 1844, o nascimento da Caixa Econômica (em Hamburgo/Alemanha no ano de 1778, na Inglaterra e nos Estados Unidos em 1816), o estabelecimento do projeto de "seguro operário" de Bismarck (1869) que ocasionou a instituição do seguro-doença-maternidade (1883), do seguro de acidentes do trabalho (1884), do seguro invalidez-velhice (1889) e finalmente do Regulamento de Seguro do Reich (1911).

Após a Primeira Grande Guerra, verificou-se a expansão do seguro social obrigatório por todo o mundo, exceto nos Estados Unidos.

O êxito verificado no âmbito da Previdência não ocorreu no campo da Assistência, o grande desafio ainda a vencer.

Neste contexto foi firmada a Carta do Atlântico pelo Presidente dos Estados Unidos (Franklin Roosevelt) e pelo Primeiro-Ministro da Inglaterra (Winston Churchill), estabelecendo - entre outros - o compromisso de buscar a segurança social e a garantia de os homens viverem "livres do medo e da necessidade". 68

de forma incontestável sua condição de autênticos direitos fundamentais, já que nas Cartas anteriores os direitos sociais se encontravam positivados no capítulo da ordem econômica e social, sendo-lhes, ao menos em princípio e ressalvadas algumas exceções, reconhecido caráter meramente programático, enquadrando-se na categoria das normas de eficácia limitada."

${ }^{67}$ Confira-se, sobre o tema, a obra de Marcus Orione Gonçalves Correia e Érica Paula Barcha Correia (Curso de Direito da Seguridade Social. 3. ed. São Paulo: Saraiva, 2007. p. 1-11).

${ }^{68}$ Idem, ibidem, p. 7. 
Willian Beveridge foi escolhido pelo governo para formular o plano de reconstrução social inglesa. Ele o fez e estabeleceu cinco "gigantes na estrada da reconstrução": necessidade, doença, ignorância, carência (desamparo) e desemprego. As metas seriam alcançadas mediante a cooperação entre o Estado e o indivíduo, nos seguintes termos:

\begin{abstract}
O Estado proveria a seguridade social, mediante a contribuição dos indivíduos, que acobertaria a eles e a sua família. Para acabar com as necessidades da população, era preciso findar com a visão vitoriana de caridade, passando a existir uma atuação mais efetiva e consistente do Estado. Para isso, seis princípios foram implantados: benefícios adequados; benefícios cujos valores fossem divididos de forma justa; contribuições em quotas justas; unificação da responsabilidade administrativa; acobertamento das necessidades básicas da população; classificação das necessidades. ${ }^{69}$
\end{abstract}

A aplicação do Plano Beveridge encontrou fortes resistências do Partido Conservador e até do próprio Churchill, que o havia encomendado.

Foi então substituído por medidas tímidas e finalmente aplicado pelo Governo Trabalhista que assumiu o poder no período de 1944 a 1949, uma grande incoerência:

\footnotetext{
Percebe-se que, a despeito de talhado por um liberal para liberais, o Plano acabou por ser utilizado por socialistas rumo ao socialismo. Na origem, portanto, a Previdência Social se adequava perfeitamente ao Estado Socialista, sendo que o Welfare State se apoderou da ideia, adaptando-se às suas necessidades. ${ }^{70}$
}

No Brasil, sua primeira Constituição (1824) apenas determinava a garantia dos socorros públicos, sem qualquer outra especificação (artigo 179, XXXVI), regra que tem sido interpretada pela doutrina pátria como o dever do Imperador de prestar assistência social, pouco se sabendo, no entanto, sobre sua efetividade.

A legislação infraconstitucional, por sua vez, estabeleceu alguns institutos de natureza previdenciária e relativos apenas aos funcionários públicos, como por exemplo a Caixa de Socorros em cada uma das estradas de ferro do Estado (Lei n 3.397, de 24/11/1888), o Fundo de Pensões do Pessoal das Oficinas da Imprensa Nacional (Decreto $\mathrm{n}^{\mathrm{o}} 10.269$, de 20/07/1889) e a aposentadoria para os empregados da Estrada de Ferro do Brasil (Decreto $n^{\circ} 221$, de 26/02/1890). ${ }^{71}$ Afirma Paulo Márcio Cruz que:

\footnotetext{
${ }^{69}$ Idem, ibidem, p. 8.

${ }^{70}$ Idem, ibidem, p. 10.

${ }^{71}$ Idem, ibidem, p. 13.
} 


\begin{abstract}
A Lei 3.397, de 24.11.1888, determinava a criação de uma caixa de socorros para os trabalhadores das estradas de ferro de propriedade do Estado. Depois, sobrevieram o Decreto 9.212-A, de 26.03.1889, tratando do montepio obrigatório dos empregados dos correios, e o Decreto 10.269, de 20 de julho do mesmo ano, criando o fundo especial de pensões dos trabalhadores das oficinas da Imprensa Régia. Para os servidores públicos, o conjunto dos benefícios era um direito que decorria do exercício da função, enquanto a previdência dos trabalhadores da iniciativa privada será criada exigindo-se o recolhimento de contribuições, como leciona Mozart Victor RUSSOMANO, em seu Curso de Previdência Social, p. 29-30. ${ }^{72}$
\end{abstract}

Sob a égide da Constituição de 1891, foi editada a Lei Eloy Chaves (Decreto Legislativo $n^{\circ} 4.682 / 1923$ ), que estendeu a previdência social urbana aos trabalhadores da iniciativa privada, sendo autorizada a criação de Caixas de Aposentadorias e Pensões (CAPs). ${ }^{73}$ Referido ato normativo é usualmente invocado como o marco inicial da Previdência Social no Brasil.

No entanto, há quem defenda já estar configurada a noção de Previdência em 15/01/1919, quando foi editada a Lei $\mathrm{n}^{\circ} 3.724$, dispondo sobre o seguro de acidentes do trabalho, a cargo das empresas, que deveriam contratá-lo obrigatoriamente com seguradoras privadas. ${ }^{74}$

A Constituição de 1934 foi promulgada no Governo de Getúlio Vargas e no contexto mundial do Pós-Guerra e Pós-Crise de 1929.

Os direitos trabalhistas foram expressa e minuciosamente reconhecidos e assegurados no Título relativo à Ordem Econômica e Social. O direito à Previdência, disciplinado na alínea $h$ do $\S 1^{\circ}$ do artigo 121, era umbilicalmente ligado ao direito do Trabalho e de cunho contributivo.

A Constituição de 1934 recebeu forte influência da Constituição de Weimar de 1919 e pela primeira vez na história constitucional brasileira conferiu destaque aos direitos sociais. Também de forma inédita, instituiu a obrigação do Estado de contribuir, ao lado do empregador e do empregado, para a Previdência Social.

\footnotetext{
72 CRUZ, Paulo Márcio. Fundamentos Históricos, Políticos e Jurídicos da Seguridade Social. In ROCHA, Daniel Machado; SAVARIS, José Antonio (coords.). Curso de Especialização em Direito Previdenciário - volume I - Direito Previdenciário Constitucional. 1. ed. (2005), 2. tir. Curitiba: Juruá Editora, 2006. p. 73 , nota de rodapé 123.

${ }^{73}$ É bom destacar que não havia qualquer contribuição estatal em favor das CAPs, mas tão somente por parte das empresas, responsáveis pelo recolhimento de suas próprias contribuições, de seus trabalhadores e dos usuários de seus serviços.

${ }^{74}$ ROCHA, Daniel Machado. O Direito Fundamental à Previdência Social na perspectiva dos princípios constitucionais diretivos do sistema previdenciário brasileiro. Porto Alegre: Livraria do Advogado Editora, 2004. p. 52.
} 
O texto constitucional de 1937 tratou dos direitos sociais (trabalhista e previdenciário) no Título relativo à Ordem Econômica, mas pouco representou em termos de avanço.

Já a Constituição de 1946 estabeleceu expressamente que a ordem econômica deveria ser organizada de acordo com princípios da justiça social, conciliando a liberdade de iniciativa com a valorização do trabalho humano (artigo 145), embora tenha mantido os direitos sociais no Título da Ordem Econômica.

Durante sua vigência, foi editada a Lei Orgânica da Previdência Social (LOPS - Lei $n^{\circ}$ 3.807/60), que unificou a legislação esparsa até então existente. Também foi criado o FUNRURAL - Fundo de Assistência ao Trabalhador Rural (Lei 4.214/63), possibilitando a concessão de benefícios previdenciários aos trabalhadores rurais e o INPS - Instituto Nacional de Previdência Social (Decreto-Lei nº 72/66).

Por fim, na Constituição promulgada no período da ditadura militar (Constituição de 1967 e Emenda Constitucional $\mathrm{n}^{\circ}$ 01/1969), os direitos trabalhistas sofreram fortes restrições, ao passo que o direito à Previdência Social foi estendido a categorias de beneficiários até então não contempladas (empregados domésticos, trabalhadores rurais e autônomos).

Leis infraconstitucionais, especialmente as Leis Complementares ns. 11/71 e 16/73, em complemento à legislação já existente (FUNRURAL - Lei 4.214/63), asseguraram aos trabalhadores rurais direitos a benefícios previdenciários.

Em 01/09/1977 foi criado o SINPAS - Sistema Nacional de Previdência e Assistência Social,

\footnotetext{
com o escopo de integrar todas as atribuições ligadas à previdência urbana e rural, tanto a dos servidores públicos federais quanto os das empresas privadas, composto de sete órgãos: INPS, IAPAS, INAMPS, LBA, FUNABEM, DATAPREV e CEME. Cada organismo deveria desempenhar suas funções específicas, independentemente da qualidade profissional dos beneficiários. Concomitantemente ao surgimento do SINPAS, promoveu-se a extinção do FUNRURAL, do SASSE e do IPASE. ${ }^{75}$
}

Em linhas gerais, a história da previdência social brasileira pode ser sintetizada nas seguintes observações:

A previdência dos trabalhadores brasileiros, criada na década de 20 do século passado, sob inspiração do modelo elaborado na Alemanha por Otto Von Bismark, em um primeiro momento, protegia os empregados por categoria

${ }^{75}$ Idem, ibidem, p. 70. 
profissional, sob o argumento de que, estando as instituições securitárias mais próximas dos empregadores, haveria uma relação mais direta entre eles e os segurados. Além disso, as regras de custeio eram variáveis de acordo com a capacidade de pagamento do trabalhador. A partir da década de 60, há uma virada na estrutura do sistema, que passa a seguir uma concepção de previdência idealizada pelo economista inglês William Beveridge. Este novo modelo fica então fundado no princípio da universalidade, com atendimento de toda a população, na uniformidade de tratamento, mediante a padronização do plano para todos os trabalhadores, com limites mínimo e máximo de proteção, e na administração unificada do seguro. É o regime geral estabelecido até hoje.

O sistema dos servidores públicos nasceu com a proteção assistemática e gratuita de determinadas categorias funcionais pela legislação do Império. Durante a República, o sistema previdenciário próprio foi aprimorado, mas manteve, em linha geral, o financiamento exclusivo do seguro pelo estado, sem participação do servidor. Somente com a entrada em vigor da EC 3/93, houve previsão constitucional de cobrança de contribuição dos funcionários para o custeio do regime. $^{76}$

\subsubsection{Estado de Bem-Estar Social no Brasil}

Apresentamos o caminho percorrido pelo Estado brasileiro na consolidação da Previdência Social com o objetivo de demonstrar o grande passo dado pelo legislador constituinte em 1988 e, como veremos no Capítulo 2, a impossibilidade de retornar ao estágio anterior, por força do princípio da vedação do retrocesso social.

A interpretação sistemática do texto constitucional nos leva a perceber que o direito fundamental à previdência social não se encontra albergado apenas no artigo $6^{\circ}$ da Constituição Federal, mas também em outros dispositivos, especialmente os artigos 194, 201 e 202.

A Carta de 1988

realizou, por inteiro, o ideal e o sonho de Josué de Castro, para quem o desenvolvimento da previdência social constitui o triunfo dos ideais éticos que desde remotas eras acendem no coração dos homens a centelha da solidariedade, não apenas naqueles que coexistem no tempo, mas até mesmo entre as gerações que se sucedem. ${ }^{77}$

O espectro da proteção social projetado pela nova ordem é suficiente para afirmar que houve a real intenção de se implantar no Brasil um Estado de Bem-Estar Social, definido como "o sistema político-econômico que, mantendo um âmbito privado capitalista, encarrega o Estado de tarefas relativas à obtenção de condições sociais

\footnotetext{
${ }^{76}$ TAVARES, Marcelo Leonardo. Princípios Constitucionais dos direitos fundamentais e o limite à reforma da previdência social. IN: ROCHA, Daniel Machado; SAVARIS, José Antonio (coords.). Curso de Especialização em Direito Previdenciário - volume I - Direito Previdenciário Constitucional. 1. ed. (2005), 2. tir. Curitiba: Juruá Editora, 2006. p. 208-209.

${ }^{77}$ CÉSAR, Afonso. A face oculta e cruel da reforma da Previdência. Brasília: Cedil, 1995, p. 12.
} 
mínimas". ${ }^{78}$ Apesar de ser o responsável pela promoção e efetividade dos direitos sociais, este modelo não se aparta do sistema capitalista de produção, antes concilia os anseios da classe trabalhadora com a preservação do capitalismo. ${ }^{79}$

Tem o condão, por assim dizer, de promover alguma redistribuição de renda, na medida em que aqueles com melhores condições financeiras devem - pelo menos em tese - contribuir mais, em prol daqueles desprovidos de recursos, atuando o Estado como intermediário e promotor da redistribuição.

\begin{abstract}
A "compensação" das condições sociais dos mais favorecidos e dos pobres, pela mediação do Estado, é o que define o Welfare State. Esse modo de atuação do Estado, não mais limitado ao "governo das leis", mas transcendendo-o com um "governo de políticas", as quais se realizam pela efetividade dos chamados direitos sociais, é o diferencial jurídico do século XX.

Os direitos sociais, cuja existência justifica a formulação das políticas públicas de educação, saúde, previdência e assistência como processos de eliminação de desigualdades, estariam num plano diferente dos direitos individuais. Enquanto os últimos, direitos de liberdade, asseguram a igualdade de todos perante o Estado, os primeiros consagrariam uma certa forma de equiparação, em nome da promoção da igualdade de oportunidades sociais. ${ }^{80}$
\end{abstract}

A crise social, política e econômica gerada pelas Guerras Mundiais obrigou uma maior participação do Estado na promoção do bem-estar da coletividade. Portanto, o que desencadeou este novo tipo de atuação estatal foi

\begin{abstract}
a preocupação diante do aumento desenfreado do desemprego provocado pela passagem de uma economia de guerra para outra de paz, as consequências internacionais da Revolução Russa - especialmente entre as classes trabalhadoras - as revoltas sociais causadas pelos vários conflitos armados e de classes, e o acesso ao Poder da esquerda (...). ${ }^{81}$
\end{abstract}

O Professor Paulo Márcio Cruz, com amparo na obra de Jordi Sánches, indica alguns fatos históricos que colaboraram para o nascimento do Estado de Bem-Estar:

a) A tradição de criar associações de trabalhadores que perseguiam, entre outras finalidades, objetivos assistenciais. Seu âmbito de atuação era claramente sindical, e seu funcionamento se dava à margem do Estado. Os sindicatos foram uma tentativa de oferecer uma resposta às múltiplas disfunções sociais que foram geradas pela Revolução Industrial;

b) $\mathrm{O}$ aparecimento da miséria como consequência do processo de industrialização e a formação de grandes aglomerados humanos nos núcleos

${ }^{78}$ CRUZ, Paulo Márcio. Op. cit., p. 29.

${ }^{79}$ CORREIA, Marcus Orione Gonçalves; CORREIA, Érica Paula Barcha. Curso de Direito da Seguridade Social. 3. ed. São Paulo: Saraiva, 2007. p. 32.

${ }^{80}$ BUCCI, Maria Paula Dallari. A Reforma Constitucional da Previdência. O Direito à Aposentadoria como Direito Fundamental e seu Conteúdo. Revista dos Tribunais, ano 3, nº 12, julho-setembro de 1995, p. 117.

${ }^{81}$ CRUZ, Paulo Márcio. Op. cit., p. 47. 
urbanos. O fenômeno da miserabilidade urbana atinge fortemente as instituições caritativas e assistenciais clássicas e fez que se começasse a perceber como necessária a intervenção das instituições públicas, que no princípio foi promovida pelo Município;

c) Começa a entrar em crise o princípio existente de responsabilidade compartilhada entre o trabalhador e a empresa no que se referia aos acidentes de trabalho. A razão desta crise foi a importância numérica que estes acidentes passaram a ter no mundo operário, com consequências muito graves. Começaram a prosperar teses de que o Estado devesse regular as responsabilidades por estes acidentes. Isto fez que o Estado Mínimo, próprio do Liberalismo clássico, passasse a ser muito questionado. ${ }^{82}$

O Brasil não viveu o cenário pós-guerra acima retratado, embora tenha sofrido as consequências da crise internacional.

Somado a isso, também enfrentava crises na área social, no setor financeiro e na arena política, resultantes, sobretudo, do longo período de ditadura militar de que o país acabava de sair, demandando um novo tipo de atuação estatal, voltada à prestação das necessidades essenciais da coletividade.

Neste contexto, as inovações da Carta de 1988 representaram um notável avanço, especialmente em matéria de proteção social, como apontam os Professores Marcus Orione e Jorge Souto Maior:

\begin{abstract}
Esta inserção de normas de natureza social na Constituição se justifica porque a concretização de seus preceitos não depende meramente do conjunto de obrigações na esfera individual, mas da conjugação de diversos fatores socioeconômicos de todo um corpo social e, em especial, da atuação do próprio Estado, que neste contexto não mais aparece como mero ente coercitivo da ordem jurídica, mas como estimulador, financiador e promotor dos direitos constitucionalmente assegurados. A fixação na Constituição de interesses sociais representa, por assim dizer, um compromisso do estado e da sociedade com o implemento e satisfação de tais interesses, sendo o Estado até mesmo um sujeito passivo obrigado a efetivá-los. Juridicamente, o Estado deixa de ser um mero legitimador dos interesses dos dominantes e transfigura-se em autêntico Estado social (pelo menos no prisma do direito). Em se tratando a Constituição de documento no qual se concretiza a unidade política de uma nação, há verdadeiro reconhecimento de que o espaço do político não pode desconsiderar os direitos sociais. ${ }^{83}$
\end{abstract}

De forma inaugural, o texto constitucional inseriu os direitos sociais na categoria dos direitos fundamentais (Título II, Capítulo II) e como tal os tornou imunes a qualquer alteração posterior, ainda que levada a efeito por meio de emenda constitucional.

${ }^{82}$ CRUZ, Paulo Márcio. Fundamentos Históricos, Políticos e Jurídicos da Seguridade Social. In Op. cit., p. 34-35.

${ }^{83}$ CORREIA, Marcus Orione Gonçalves; MAIOR, Jorge Luiz Souto. O que é Direito Social? In CORREIA, Marcus Orione Gonçalves (org.). Curso de Direito do Trabalho: teoria geral do Direito do Trabalho. São Paulo: LTr, 2007. v. 1, p. 22. 
Também de maneira inédita, estabeleceu os pilares da Seguridade Social, assim entendida como um "conjunto integrado de ações de iniciativa dos Poderes Públicos e da sociedade, destinadas a assegurar os direitos relativos à saúde, à previdência e à assistência social" (artigo $194 \mathrm{CFR} / 88$ ).

Além da disposição expressa contida no caput do artigo $6^{\circ}$ e de alguns direitos previdenciários assegurados no artigo $7^{\circ}$, como nos incisos II (seguro-desemprego, em caso de desemprego involuntário), XVIII (licença a gestante, sem prejuízo do emprego e do salário, com a duração de cento e vinte dias) e XXIV (aposentadoria), cuidou do direito fundamental à Previdência Social (Regime Geral) de forma detalhada nos artigos 201 e 202.

Tais normas informam o conteúdo deste direito e indicam o que pelo menos deve ser assegurado e que não pode subtraído do patrimônio dos beneficiários da Previdência. ${ }^{84}$

Dois pontos merecem maiores esclarecimentos.

O primeiro deles consiste em esclarecer o que nos leva a concluir que os direitos sociais estão protegidos por cláusulas pétreas, já que o inciso IV do $\S 4^{\circ}$ do artigo $60^{85}$ da Constituição Federal apenas faz menção aos direitos fundamentais individuais.

A interpretação sistemática e teleológica do texto constitucional só pode conduzir à inclusão dos direitos sociais na norma protetiva, pois não haveria sentido algum em reconhecer expressamente a natureza fundamental dos direitos sociais e permitir sua alteração (e até mesmo sua revogação) por emendas constitucionais posteriores.

A interpretação literal também nos faria concluir, como salientado por Ingo Sarlet $^{86}$, que também os direitos de nacionalidade e os direitos políticos não estariam acobertados por cláusulas pétreas.

$\mathrm{Na}$ outra ponta, a interpretação sistemática do texto constitucional revela que a intenção do legislador constituinte foi a de construir um Estado Democrático de Direito fundado na realização dos direitos fundamentais individuais e sociais.

\footnotetext{
${ }^{84}$ Como veremos no Capítulo 2, o princípio do não retrocesso social é um dos vetores que deve orientar o Poder Judiciário no controle das políticas públicas, impedindo que as normas de proteção social sejam suprimidas ou tenham seu conteúdo reduzido.

85 "Art. 60. (...)

$\S 4^{\circ}$ Não será objeto de deliberação a proposta de emenda tendente a abolir:

I - a forma federativa de Estado;

II - o voto direto, secreto, universal e periódico;

III - a separação dos Poderes;

IV - os direitos e garantias individuais."

${ }^{86}$ SARLET, Ingo. Op. cit., 2007b, p. 425.
} 
Já no preâmbulo de nossa Constituição encontramos referência expressa no sentido de que a garantia dos direitos individuais e sociais, da igualdade e da justiça constitui objetivo permanente de nosso Estado. Além disso, não há como negligenciar o fato de que nossa Constituição consagra a ideia de que constituímos um Estado democrático e social de Direito, o que transparece claramente em boa parte dos princípios fundamentais, especialmente no art. $1^{\circ}$, incs. I a III, e art. $3^{\circ}$, incs. I, III e IV. Com base nestas breves considerações, verifica-se, desde já, a íntima vinculação dos direitos fundamentais sociais com a concepção de Estado da nossa Constituição. Não resta qualquer dúvida de que o princípio do Estado Social, bem como os direitos fundamentais sociais, integram os elementos essenciais, isto é, a identidade de nossa Constituição, razão pela qual já se sustentou que os direitos sociais (assim como os princípios fundamentais) poderiam ser considerados - mesmo não estando expressamente previstos no rol das "cláusulas pétreas" - autênticos limites materiais implícitos à reforma constitucional. Poder-se-á argumentar, ainda, que a expressa previsão de um extenso rol de direitos sociais no título dos direitos fundamentais seria, na verdade, destituída de sentido, caso o Constituinte, ao mesmo tempo, tivesse outorgado a estes direitos proteção jurídica diminuída. ${ }^{87}$

O segundo ponto consiste em estabelecer o conteúdo do direito fundamental em questão para só assim saber o que está a salvo de alterações posteriores.

Descobrir tal conteúdo, no entanto, não é fácil. Adverte o Professor Marcus Orione Gonçalves Correia que

há que se fazer, e essa tarefa não é fácil (por isso não tem sido feita constantemente), uma busca profunda do que preserva o conceito constitucional, ou seja, do que é nuclear na manutenção do direito fundamental de previdência, de assistência e de saúde. (...) O problema básico aqui é de força normativa da Constituição, que só vai ser preservada onde os direitos individuais e direitos sociais são preservados, sem ceder a pressões de natureza meramente contingencial e fática. Dentro deste contexto, uma vez localizados constitucionalmente os direitos sociais e colocados como direitos fundamentais, nossa dinâmica de interpretação vai ser aquela que busca a unidade políticoconstitucional dentro desse sistema. ${ }^{88}$

A análise das normas constitucionais relativas à matéria previdenciária logo revela que nem todas cuidam de questões materialmente constitucionais, mas de assuntos próprios à legislação infraconstitucional. ${ }^{89}$

De outro lado, uma vez identificado o conteúdo do direito fundamental, é essencial adotar a premissa de que esta é a sua configuração mínima, vale dizer, é o mínimo que o Estado deve realizar na esfera previdenciária e que não pode ser reduzido ou suprimido

${ }_{88}^{87}$ Idem, ibidem, p. 426-427.

${ }^{88}$ CORREIA, Marcus Orione Gonçalves. Interpretação do direito da segurança social. In ROCHA, Daniel Machado; SAVARIS, José Antonio (coords.). Curso de Especialização em Direito Previdenciário volume I - Direito Previdenciário Constitucional. 1. ed. (2005), 2. tir. Curitiba: Juruá Editora, 2006. p. 264.

${ }^{89}$ Cite-se, como exemplo, o artigo 201, § $6^{\circ}$, da Constituição Federal, pelo qual o abono anual (ou gratificação natalina) deve ter o mesmo valor dos proventos pagos no mês de dezembro de cada ano. 
pelo legislador posterior, ainda que através de emenda constitucional. Pode, e assim se espera, ser aumentado, nunca diminuído.

Para o Professor Marcelo Leonardo Tavares,

\begin{abstract}
a previdência fundamental deve ser baseada nos princípios da universalidade, da uniformidade e da solidariedade na proteção dos segurados mais desvalidos, mediante a participação do Estado; na cobertura dos riscos sociais da morte, da idade avançada, da incapacidade, da maternidade e do desemprego involuntário; e no estabelecimento de patamares mínimo e máximo de pagamento dos benefícios, com a manutenção real do valor das prestações ${ }^{90}$.
\end{abstract}

Este é, a seu ver, o conteúdo do direito fundamental em questão, o limite mínimo de proteção securitária pública. ${ }^{91}$ Concordamos com o conteúdo do direito fundamental à previdência social indicado, na medida em que não é possível compreender um sistema de previdência social que não estabeleça quais as contingências acobertadas e quais os parâmetros que devem ser observados pelo legislador infraconstitucional na fixação do valor do benefício, de forma que garanta a sobrevivência do beneficiário em condições dignas.

É o conteúdo do direito fundamental que está a salvo de alterações posteriores, ainda que introduzidas através de reformas constitucionais, em respeito ao inciso IV do $\S$ $4^{\circ}$ do artigo 60 da Constituição Federal.

Identificado o conteúdo do direito fundamental, devem ser buscadas no texto constitucional e na legislação que o regulamenta as diretrizes da política de Estado em matéria previdenciária voltadas a concretizá-lo e que devem nortear, obrigatoriamente, todas as políticas de Governo editadas para o mesmo fim.

\title{
1.5.3. A influência dos postulados neoliberais
}

Não obstante o grande avanço das normas de proteção social previstas no texto constitucional e antes mesmo da sua completa concretização, inúmeras modificações foram feitas. $^{92}$

\footnotetext{
${ }^{90}$ A Constitucionalização do Direito Previdenciário. In NETO, Cláudio Pereira de Souza; SARMENTO, Daniel (coords.). A Constitucionalização do Direito: Fundamentos Teóricos e Aplicações Específicas. Rio de Janeiro: Editora Lumen Juris, 2007. p. 949.

${ }^{91}$ Idem, ibidem, p. 950.

${ }^{92}$ Até dezembro de 2009, 62 (sessenta e duas) emendas constitucionais foram promulgadas, além de 6 (seis) emendas constitucionais de revisão.
} 
Modificações no texto constitucional são possíveis e desejadas, pois possibilitam que ele reflita, tanto quanto possível, a vontade da maioria na adoção do novo modelo, vinculando todos - Poder Público e sociedade civil - na sua realização. Duas são as condições impostas: ( $i$ ) o respeito ao disposto no $\S 4^{\circ}$ do artigo 60 da Constituição Federal $^{93}$; e (ii) a observância do procedimento específico ${ }^{94}$.

A área previdenciária foi uma das que mais sofreram alterações. São de relevo as Emendas 20, promulgada em 1998, no governo do Presidente Fernando Henrique Cardoso, e 41, promulgada em 2003, durante o governo do Presidente Lula.

A Emenda 20 cuidou essencialmente das mudanças efetuadas no Regime Geral de Previdência Social, ao passo que a Emenda 41 tratou das alterações voltadas ao funcionalismo público.

As reformas foram motivadas pelos seguintes fatores: $(i)$ os altos valores dos benefícios, muitos deles sem qualquer contrapartida anterior; (ii) o crescente déficit do orçamento da Seguridade Social; (iii) a ocorrência de reformas previdenciárias em vários outros países; (iv) aumento da expectativa de vida e $(v)$ a tentativa de unificação dos regimes de previdência - público e privado.

No cenário mundial, a crise do Estado de Bem-Estar Social veio à tona na década de 70 .

De um lado, o modelo passou a ser combatido essencialmente por inchar o Estado de gastos e de serviços; de outro lado, as principais nações do mundo enfrentavam os efeitos da crise do petróleo. Mostrou-se então necessária a propositura de uma nova agenda, apta a resolver a crise econômica que perturbava as grandes nações.

Encabeçado pelo Governo Reagan, nos Estados Unidos, e por Margareth Thatcher, na Inglaterra, o neoliberalismo foi apresentado como a solução adequada para a crise que se colocava, e foi adotado, com algumas nuances, por um grande número de países. Retomou-se, com força total, a ideia de Estado mínimo nas esferas política, social e econômica, motivada pela bandeira da liberdade individual.

O neoliberalismo, nas palavras de David Harvey ${ }^{95}$, é

\footnotetext{
93 "Art. 60. (...)

$\S 4^{\circ}$ Não será objeto de deliberação a proposta de emenda tendente a abolir:

I - a forma federativa de Estado;

II - o voto direto, secreto, universal e periódico;

III - a separação dos Poderes;

IV - os direitos e garantias individuais."

${ }^{94} \mathrm{O}$ procedimento de emenda à Constituição está disciplinado pelo artigo 60 e parágrafos da CFR/88.

95 Geógrafo marxista britânico, professor da City University of New York e autor de várias obras, entre as quais: Explanation in Geography (London: Edward Arnold, 1969); A Justiça Social e a Cidade (Tradução:
} 
em primeiro lugar uma teoria das práticas político-econômicas que propõe que o bem-estar humano pode ser melhor promovido liberando-se as liberdades e capacidades empreendedoras individuais no âmbito de uma estrutura institucional caracterizada por sólidos direitos a propriedade privada, livres mercados e livre comércio. O papel do Estado é criar e preservar uma estrutura institucional apropriada a essas práticas; o Estado tem de garantir, por exemplo, a qualidade e a integridade do dinheiro. Deve também estabelecer as estruturas e funções militares, de defesa, da polícia e legais requeridas para garantir direitos de propriedade individuais e para assegurar, se necessário pela força, o funcionamento apropriado dos mercados. Além disso, se não existirem mercados (em áreas como a terra, a água, a instrução, o cuidado de saúde, a segurança social ou a poluição ambiental), estes devem ser criados, se necessário pela ação do Estado. Mas o Estado não deve aventurar-se para além dessas tarefas. As intervenções do Estado nos mercados (uma vez criados) devem ser mantidas num nível mínimo, porque, de acordo com a teoria, o Estado possivelmente não possui informações suficientes para entender os sinais do mercado (preços) e porque poderosos grupos de interesse vão inevitavelmente torcer e viciar as intervenções do Estado (particularmente nas democracias) em seu próprio benefício. $^{96}$

Sem adentrar profundamente nas características e resultados advindos da adoção deste novo modelo ideológico de atuação estatal, é importante ressaltar que as promessas e milagres anunciados não apresentaram os resultados esperados. Confira-se:

Apesar de toda a retórica da cura de economias doentes, nem a Inglaterra nem os Estados Unidos alcançaram altos níveis de desempenho econômico nos anos 1980, o que sugere que o neoliberalismo não era a resposta às orações capitalistas. É verdade que a inflação desabou e as taxas de juros aumentaram, mas o preço disso foram altas taxas de desemprego (uma média de 7,5\% nos Estados Unidos de Reagan e mais de $10 \%$ na Inglaterra de Thatcher). Cortes em benefícios sociais e em despesas com infraestrutura reduziram a qualidade de vida de muitas pessoas. O resultado geral foi uma estranha mistura de baixo crescimento e crescente desigualdade de renda. Na América Latina, por outro lado, atingida pela primeira onda de neoliberalização forçada no começo dos anos 1980, o resultado foi em geral toda uma "década perdida" de estagnação econômica e perturbação política. ${ }^{97}$

\section{Segundo Daniel Sarmento,}

a exclusão social produzida neste contexto é alarmante. Segundo relatórios das Nações Unidas, em 1962, antes do advento do neoliberalismo e da aceleração do processo de globalização, os $20 \%$ mais ricos da população tinham recursos 30 vezes superiores aos $20 \%$ mais pobres. Em 1994 esse diferencial salta para 60 vezes, e em 1997 para 74 vezes. Os dados comprovam a tese de que a

Armando Corrêa da Silva, São Paulo: Hucitec, 1980); Condição Pós-moderna (Tradução: Adail Ubirajara Sobral e Maria Stela Gonçalves, São Paulo: Edições Loyola, 1993); Espaços de Esperança (Tradução: Adail Ubirajara Sobral e Maria Stela Gonçalves, São Paulo: Edições Loyola, 2004); O Novo Imperialismo (Tradução: Adail Ubirajara Sobral e Maria Stela Gonçalves, São Paulo: Edições Loyola, 2004); A produção capitalista do espaço (Tradução: Carlos Szlak, São Paulo: Annablume, 2005).

${ }^{96}$ HARVEY, David. O Neoliberalismo - história e implicações. São Paulo: Edições Loyola, 2008. p. 12.

${ }^{97}$ Idem, ibidem, p. 98. 
intervenção estatal é necessária para garantia da justiça social pois o mercado tende a aprofundar as desigualdades econômicas. ${ }^{98}$

Ao retirar do Estado as funções que possibilitavam tornar a igualdade um princípio efetivo, apenas tornou mais diferentes os já diferentes, mais ricos os já ricos e mais pobres os já pobres, como retratado por Paulo Bonavides:

Não padece dúvida que o mundo ingressou numa sociedade feudalizada, onde haverá, outra vez - agora em nível de nações -, soberanos e vassalos. Uma sociedade que há de inaugurar, ao mesmo passo, em futuro não remoto, a simbiose do feudalismo com o colonialismo.

Sobremodo enfraquecido desde as bases e estruturas de seu poder econômico e político, o País, atado a uma sociedade internacional financeiramente desorganizada, ferozmente competitiva e governada por concentrações maciças de capitais, ocupará, nesse cenário, um lugar inferior, desempenhando papel, de todo o ponto, secundário.

Numa primeira fase - é o prognóstico para o qual os fatos estão apontando - os fortes imporão aos fracos, mais do que nunca com inexorável determinação, sua vontade avassaladora e irresistível; o que, aliás, não é de admirar, porquanto já vem acontecendo.

Nações na aparência, porém colônias na substância, eis, em suma, o futuro que aguarda tais países, cuja tragédia desnacionalizadora lhes é imposta pela globalização.

Não há, por conseguinte, como festejar com palavras de otimismo a realidade que se avizinha.

A globalização é o fascismo branco do século XXI: universaliza o egoísmo e expatria a solidariedade.

Coloca numa encruzilhada os destinos da civilização: ou esta caminha armada para a luta, e não importa o holocausto que possa amanhã advir, ou baixa a cerviz e assiste, passiva, a uma capitulação sem honra, com o povo transformado em multidão, o cidadão em súdito, a nação em mercado, a constituição em decreto-lei ou medida provisória, o governante em sátrapa, o país em colônia. ${ }^{99}$

Os textos constitucionais também refletiram tal mudança de paradigmas e sofreram reformas buscando, mais e mais, reduzir a atuação estatal e enfatizar os direitos individuais. Neste compasso, também se procurou enfraquecer os direitos sociais, um dos causadores da grave crise econômica enfrentada nos anos 70, segundo se apregoava.

O Brasil adotou o caminho oposto e em 1988 promulgou sua Constituição Cidadã, com reconhecido caráter social, como visto no item anterior. Mas logo parece ter se rendido aos apelos neoliberais, promovendo mudanças no texto originário de forma que reduzisse sensivelmente a atuação estatal na prestação de serviços públicos e os custos daí decorrentes.

${ }^{98}$ SARMENTO, Daniel. Os Direitos Fundamentais nos Paradigmas Liberal, Social e Pós-Social (PósModernidade Constitucional?). In SAMPAIO, José Adércio Leite (coord.). Crise e desafios da Constituição. Belo Horizonte: Del Rey, 2004. p. 397-398.

99 BONAVIDES, Paulo. As quatro crises do Brasil Constitucional. In SAMPAIO, José Adércio Leite (coord.). Crise e desafios da Constituição. Belo Horizonte: Del Rey, 2004. p. 75-76. 
Analisando o conteúdo das Reformas Previdenciárias ocorridas em 1998 e 2001, além das alterações legais efetuadas a partir da década de 1990, o Professor José Antônio Savaris vislumbra a existência de uma política sistemática de retração nos programas sociais.

Vale a pena transcrever algumas de suas conclusões:

O processo de programmatic retrenchment (Pierson, 1994:4) se verifica não apenas como uma questão de diminuição de orçamento, mas também como o emprego de um novo modelo dos programas de bem-estar, no qual a noção de provisão social é substituída por uma direção de atuação estatal mais residual. $\mathrm{Na}$ observação de Pierson "longe de ser simplesmente uma questão de cortes imediatos de despesa pública, a retração é um fenômeno complexo e multifacetado." (Pierson 1994:17) (tradução do autor).

Governos interessados no encurtamento dos programas sociais podem decretar políticas que diminuam despesas imediatamente, como podem ordenar mudanças cujos efeitos não serão sentidos senão após muitos anos, mesmo porque os defensores das políticas reducionistas buscam estratégias que escondem a magnitude dos custos, minimizando consequências negativas de curto prazo e, por conseguinte, diminuindo a visibilidade dos impopulares programas de redução (Pierson, 1994:14).

É possível perceber-se que, no período de pouco mais de quinze anos, dá-se restrição não apenas no campo de proteção previdenciária, com a extinção de prestações previdenciárias, inclusive, como igualmente há uma diminuição do conteúdo dos benefícios, especialmente no caso das aposentadorias por tempo de contribuição. Também se pode identificar uma substituição da lógica que determinava a contrapartida previdenciária às contribuições vertidas pelos trabalhadores, fundada na inconstitucionalidade da exigência de contribuição sem causa eficiente, pela lógica que autoriza a exigência de contribuições para a seguridade social dos trabalhadores sem repercussão no nível de seu benefício, fundada em uma perspectiva de solidariedade que impõe ao obreiro aposentado o dever de contribuir para a seguridade social sem qualquer perspectiva de ampliação de cobertura previdenciária. ${ }^{100}$

$\mathrm{Na}$ questão previdenciária, embora o texto constitucional tenha sofrido alteração substantiva no ano de 1998, com a introdução da Emenda 20, o fato é que a legislação infraconstitucional já vinha sendo modificada há mais tempo. ${ }^{101}$

${ }^{100}$ SAVARIS, José Antonio. O Judiciário e a Política de Retração Sistemática da Previdência Social no Brasil. In FAGNANI, Eduardo; HENRIQUE, Wilnês; LÚCIO, Clemente Ganz. Previdência Social: Como Incluir os Exclú́dos? Uma agenda voltada para o desenvolvimento econômico com distribuição de renda. Campinas: UNICAMP - Instituto de Economia; Campinas: CESIT; São Paulo: LTr, 2008b. p. 52.

${ }^{101}$ No artigo acima indicado, o Autor expõe as sucessivas alterações ocorridas na legislação. No Regime Geral de Previdência Social, a Lei nº 8.870/94 aboliu duas prestações pecuniárias: os pecúlios (devidos aos segurado aposentado que continuava a exercer atividade remunerada) e o abono de permanência em serviço (devido ao segurado que, fazendo jus à aposentadoria integral por tempo de serviço, permanecesse em atividade sem requerê-la). A Lei $n^{\circ}$ 9.032/95, por sua vez, tornou obrigatório o pagamento de contribuição previdenciária por parte do segurado aposentado que volta a trabalhar, mas apenas possibilitou a concessão dos benefícios de salário-família, reabilitação profissional e auxílio-acidente. A lei também excluiu a pessoa designada do rol de dependentes; alterou os critérios de cálculo da renda mensal inicial dos benefícios previdenciários; restringiu as hipóteses de reconhecimento de atividade exercida em condições especiais, ampliando as exigências para a sua comprovação, entre outras alterações. Por fim, destaca as principais alterações promovidas pela Lei $\mathrm{n}^{\circ}$ 9.528/97 que retirou o auxílio-acidente da relação dos benefícios devidos 
A discussão é de relevo e sua real dimensão não tem sido percebida pelos atores políticos envolvidos. A estratégia eleita pelos Governos acaba por camuflar o conteúdo das mudanças introduzidas, notadas anos após sua promulgação, justamente no momento em que a concessão do benefício se mostra necessária e o seu valor em nada guarda relação com as contribuições vertidas e com o salário a ser substituído.

\subsubsection{Emenda Constitucional $n^{0}$ 20/1998}

Por força da crise do Estado de Bem-Estar Social iniciada na década de 70, nos anos 90 diversos países procederam a reformas nos seus sistemas previdenciários reformas estruturais e reformas não estruturais (também chamadas de incrementais ou paramétricas).

Na América Latina, o Chile foi um dos precursores e alterou seu regime previdenciário mediante reformas estruturais ${ }^{102}$, adotando o regime de capitalização, através do modelo de três pilares. A mola propulsora foi o relatório anual do Banco Mundial para o ano de 1994, intitulado Averting the Old Age Crisis. ${ }^{103}$

O modelo de três pilares tem o objetivo declarado "de aumentar a capacidade de poupança nacional para viabilizar a aceleração do desenvolvimento econômico."104 Estabelece, de forma sucinta, a necessidade de: ( $i$ ) um programa gerenciado pelo setor público e financiado com recolhimento de tributos (especialmente impostos), destinado a assegurar uma rede de segurança (que pode ser uma garantia mínima de pensão ou um benefício universal ou baseado em testes de meios). As prestações não estavam relacionadas às remunerações no modelo universalista ou eram proporcionais à remuneração até um teto baixo nos países que apresentavam um modelo laboralista (no

ao segurado aposentado que volta a trabalhar; excluiu o menor sob guarda do rol dos dependentes e modificou do termo inicial da pensão por morte, entre outras disposições.

${ }^{102}$ As reformas estruturais "são as que transformam radicalmente um sistema de seguridade social (portanto, "público"), substituindo-o, suplementando-o ou criando um sistema provado paralelo, suplementando-o ou criando um sistema público paralelo" (MESA-LAGO; Carmelo; MÜLLER, Katharina. Política e reforma da previdência na América Latina. In COELHO, Vera Schattan P. (org.). A Reforma da Previdência Social na América Latina. Rio de Janeiro: Editora FGV, 2003. p. 28).

${ }^{103}$ MELO, Marcus André. Escolha Institucional e a difusão dos paradigmas de política: o Brasil e a segunda onda de reformas previdenciárias. Rio de Janeiro, Dados, v. 47, nº 1, janeiro 2004.

${ }^{104}$ ROCHA, Daniel Machado. As aposentadorias dos servidores públicos e as reformas constitucionais. In ROCHA, Daniel Machado; SAVARIS, José Antonio (coords.). Curso de Especialização em Direito Previdenciário - volume I - Direito Previdenciário Constitucional. 1. ed. (2005), 2. tir. Curitiba: Juruá Editora, 2006. p. 177. 
qual as prestações previdenciárias se vinculam aos proventos oriundos do trabalho $)^{105}$; $(i i)$ um sistema obrigatório ou facultativo, de poupança, não redistributivo, gerenciado pelo setor privado, capitalizado de forma integral e baseado em contribuições definidas; (iii) um sistema voluntário gerenciado pelo setor privado, capitalizado de forma integral e destinado a suplementar a renda oriunda do segundo pilar, voltado às pessoas que desejam uma maior proteção previdenciária na velhice. ${ }^{106}$

O sistema previdenciário brasileiro, por sua vez, sempre foi fundado no regime de repartição simples, consagrado no texto constitucional de $1988 .^{107}$

Seguindo o fluxo de reformas ocorrido mundo afora, já a partir da década de 1990 passou-se a esboçar a Reforma da Previdência, ao fundamento de que a "generosidade" do legislador de 1988 estava impondo gastos que não cabiam nos cofres públicos.

Após vários anos de estudos e constatada a impossibilidade de adoção do modelo chileno, em razão dos custos envolvidos ${ }^{108}$, o Governo brasileiro optou por uma reforma "incremental”, fazendo ajustes no sistema de repartição. ${ }^{109}$

${ }^{105}$ VELLOSO, Andrei Pitten; ROCHA, Daniel Machado da; JÚNIOR, José Paulo Baltazar. Comentários à Lei do Custeio da Seguridade Social. Porto Alegre: Editora Livraria do Advogado, 2005. p. 53-54.

${ }^{106}$ Ressalte-se, no entanto, que já no final dos anos 90 começou a surgir grande dissenso doutrinário acerca do sucesso do regime de capitalização.

107 No regime de repartição simples, as contribuições vertidas pela geração presente são utilizadas para o pagamento dos benefícios dos inativos. Funda-se, assim, em postulado eminentemente ético, já que baseado na solidariedade intergeracional. Leda Maria Paulani enumera três princípios básicos do regime de repartição simples: a universalidade do benefício, a participação do Estado dentro do esquema tripartite de sustentação financeira (empregados, empregadores e Estado) e a solidariedade intergeracional. Segundo a Autora, "a universalidade resulta da necessidade de tornar menos rígido o vínculo entre acesso ao benefício e contribuição ao sistema; a participação do Estado decorre do primeiro princípio e significa que faz parte da característica desse regime a possibilidade da existência de déficits, os quais devem então ser custeados por meio da coleta normal de impostos; finalmente, a solidariedade intergeracional significa que quem trabalha gera renda também para quem já trabalhou. Todos esses princípios estão ligados entre si e conformam uma dinâmica que é impulsionadora do crescimento e joga do lado da valorização produtiva do capital e da distribuição de renda. Assim, o sistema será tão mais equilibrado do ponto de vista financeiro e atuarial (portanto com déficits ausentes) quanto maiores forem o emprego, a renda, o nível de salário médio real e, por consequência, a participação dos salários na renda. Ao contrário, se emprego e renda ficam estagnados ou decrescem e/ou se o salário médio real cai substantivamente, seu equilíbrio fica prejudicado e déficits, sobretudo de natureza financeira, são praticamente inevitáveis (Seguridade Social, Regimes Previdenciários e Padrão de Acumulação: uma nota teórica e uma reflexão sobre o Brasil. In FAGNANI, Eduardo; HENRIQUE, Wilnês; LÚCIO, Clemente Ganz. Previdência Social: Como Incluir os Excluídos? Uma agenda voltada para o desenvolvimento econômico com distribuição de renda. Campinas: UNICAMP Instituto de Economia; Campinas: CESIT; São Paulo: LTr, 2008. p. 24).

${ }^{108}$ Segundo consta, "os estudos nos mostraram que, em primeiro lugar, a transição para um regime de capitalização, a privatização do sistema, não era uma alternativa viável. Temos vários estudos que mostram que o custo de transição de um sistema para outro, caso fosse adotado um sistema puramente de capitalização, seria da ordem de $200 \%$ do PIB. Há vários estudos do Banco Mundial que calcularam 205\% em 98; a Cepal calculou 201,6\% em 1999; a FIP/USP calculou 255\% do PIB; IBGE/IPEA 218\%; FGV, $250 \%$, Banco Mundial, em estimativa anterior, 188\%, e a própria Cepal calculou um custo que poderia ser diferido no tempo de 6\% do PIB em 40 anos" (PINHEIRO, Vinicius C. A Experiência Brasileira, in Anais do Seminário Regional sobre as Reformas dos Sistemas de Pensão na América Latina. Brasília, MPAS). ${ }^{109}$ Carmelo Mesa-Lago denomina tal reforma como não estrutural ou paramétrica, definindo-a como aquela que melhora "um sistema público de benefícios a fim de fortalecê-lo financeiramente a longo prazo, por 
A reforma inicialmente pretendida pelo Presidente Fernando Henrique, por exigir a alteração da Constituição Federal, tornou o processo muito visível, obrigando a exposição pública e o consequente desgaste do seu proponente, razão pela qual o projeto apresentado ao Congresso foi bem menos ambicioso do que se propagava à época.

Foram aprovadas medidas que afetavam sobretudo interesses potenciais de futuros beneficiários do sistema, sendo rejeitadas aquelas cujos efeitos incidiam de forma imediata, aos atuais beneficiários. Como anotado por Marcus A. Melo,

a própria proposta de desconstitucionalização do cálculo dos benefícios e o subsequente esquema do fator previdenciário foram aprovados com facilidade porque a amplitude de seu impacto não foi percebida pelos atores envolvidos. Elas representaram uma escolha política disfarçada de escolha técnica. ${ }^{110}$

A Emenda Constitucional no 20 alterou as regras do Regime Geral de Previdência Social, embora fosse de conhecimento da equipe do governo que a promoveu que as maiores distorções estavam centradas no serviço público, na medida em que algumas categorias que nunca contribuíram sempre receberam benefícios no valor máximo. Seguem as palavras de Reinhold Stephanes, então Ministro da Previdência:

Confundir todo o sistema previdenciário com o INSS é comum porque - como disse - nele estão concentrados $86 \%$ da população previdenciária. Contudo, os maiores erros, vícios e distorções são registrados nos demais regimes que englobam os $14 \%$ restantes. Isso é fácil de ser percebido quando é feita uma comparação entre os gastos do INSS e os dos demais regimes. Ao contrário do que seria lógico, os 14\% consomem mais do que os que estão no INSS. Embora não existam teorias claramente definidas entre regimes e pessoas vinculadas ao setor público e privado (o que depende da característica e organização de cada país), nos países com modelo econômico semelhante ao nosso, a relação entre os gastos com os inativos do setor público, se comparada aos trabalhadores da iniciativa privada, não passa de um terço, assim como também o número de funcionários públicos aposentados também não ultrapassa essa proporção em relação aos ativos. Um quadro bem diferente. ${ }^{111}$

O mesmo diagnóstico é feito por Marcelo Leonardo Tavares, apontando a ocorrência de graves distorções nos benefícios pagos aos servidores públicos, verbis:

exemplo, incrementando a idade de aposentadoria ou o valor das contribuições ou ainda tornando mais exata a fórmula de calcular o benefício" (MESA-LAGO, Carmelo. A reforma estrutural dos benefícios de seguridade social na América Latina: modelos, características, resultados e lições. In COELHO, Vera Schattan P. (org.). A Reforma da Previdência Social na América Latina. Rio de Janeiro: Editora FGV, 2003. p. 229).

${ }^{110}$ MELO, Marcus André. Op. cit., 2004.

${ }^{111}$ STEPHANES, Reinhold. Reforma da Previdência sem segredos. Rio de Janeiro: Record, 1998. p. 34. 
Até a promulgação da Emenda Constitucional no $3 / 93$ não havia um sistema propriamente previdenciário para os servidores, organizado na Constituição. Em algumas entidades da Federação as aposentadorias e pensões eram um favor do Estado, enquanto outros os funcionários contribuíam somente para pensão, como ocorre, ainda hoje, com os militares. Em um sistema que funciona dessas bases, não se aplicam princípios previdenciários, em especial o de equilíbrio atuarial. $\mathrm{O}$ raciocínio é bem diferente: a sociedade sustenta seus servidores mediante ingressos públicos obtidos com receita tributária genérica, em reconhecimento à relevância de serviços prestados. Por este motivo, justificavam-se alguns institutos na legislação, como a cassação de aposentadoria dos funcionários inativos que não se mostram dignos do reconhecimento do povo, medida incompatível em um sistema de previdência, no qual não se pode cassar um provento em relação ao qual houve correspondente contribuição. O fato é que as legislações foram aos poucos sendo modificadas até a consolidação da proteção dos servidores na forma previdenciária. Contudo, tal mudança não pode ser operada sem que seja gerado déficit, a não ser que as entidades que até então mantinham os proventos dos inativos e pensionistas em regime assistencial arquem com suas responsabilidades na compensação financeira da transformação, o que, não é preciso afirmar, não foi realizado no Brasil. Assim, os servidores migraram de um sistema assistencial sob responsabilidade total do Estado para um regime previdenciário, no qual deveria ser mantido equilíbrio orçamentário e respeito a regras atuariais, sem a devida contrapartida dos entes públicos. ${ }^{112}$

Apenas contextualizando: em face das disparidades e irregularidades verificadas nos benefícios concedidos ao funcionalismo público, subordinado a regime jurídico diverso ao aplicável aos demais trabalhadores, inclusive em relação à previdência, foi aprovada a Emenda 20, contendo alterações voltadas aos beneficiários do Regime Geral.

Esta constatação já causa - ou deveria causar - alguma perplexidade, pois se reformou, inicialmente, uma área da Previdência que não apresentava tantas discrepâncias. Pelo menos no Brasil.

Por que, então, reformar?

De acordo com o então Ministro da Previdência, pelo caráter didático da medida. Em suas palavras,

o que fica evidente é que, embora a reforma não tenha sido proposta para sanear o INSS, na verdade foi por esse regime que ela começou. Significa dizer também que a reforma extrapolou o limite da discussão no Congresso Nacional, e isso não aconteceu sem motivos, porque ao melhorarmos a gerência e a legislação do maior regime do país, a sociedade constatava que a casa estava sendo colocada em ordem e que as mudanças não iriam atingir somente alguns segmentos. Ao contrário. Foi uma oportunidade de comprovar que o Governo estava fazendo o $\underline{\text { seu dever de casa. Revelou-se, ainda, que as correntes contrárias à reforma eram }}$ integradas por categorias mais favorecidas socialmente e que não pertenciam ao regime INSS. $^{113}$ (grifo meu).

112 TAVARES, Marcelo Leonardo. Reforma da Previdência - um resumo da mudança. In TAVARES, Marcelo Leonardo (coord.). Direito Previdenciário. Niterói: Impetus, 2005. p. 223.

${ }^{113}$ STEPHANES, Reinhold. Op. cit., p. 48. 
Algumas dúvidas pairam no ar: (i) para quem o Governo estava prestando contas? (ii) quais as tarefas que ele tinha que realizar? (iii) colocar a casa em ordem poderia significar a alteração do conteúdo do direito fundamental, se necessário fosse, ainda que para efeitos didáticos?

Pois bem, com estes fundamentos foram introduzidas alterações no texto constitucional, veiculadas na Emenda Constitucional $\mathrm{n}^{\mathbf{0}} 20$, publicada em 16 de dezembro de 1998, das quais se destacam:

a) Constitucionalização do equilíbrio financeiro e atuarial e do caráter contributivo da Previdência, mediante alteração do caput do artigo 201.

b) Desconstitucionalização do cálculo da renda mensal inicial dos benefícios, suprimindo-se a norma originária contida no artigo $202 \mathrm{CFR}^{114}$ e apenas mantendo a disposição inscrita no $\S 3^{\circ}$ do artigo $201^{115}$. Referida alteração deu ensejo à edição da Lei ordinária $n^{\circ}$ 9.876/99 que instituiu o fator previdenciário, pelo qual a renda mensal inicial do benefício não mais equivaleria à média dos 36 (trinta e seis) últimos salários de contribuição atualizados (de acordo com o artigo 202 da CF, em sua redação originária), mas sim à média de $80 \%$ (oitenta por cento) das maiores contribuições desde julho de 1994, tomando por base a expectativa de vida do segurado.

c) Substituição da aposentadoria por tempo de serviço pela aposentadoria por tempo de contribuição, acentuando o caráter contributivo do sistema. Aos segurados já filiados à época da Emenda 20, foram estabelecidas regras de transição, consistentes basicamente no cumprimento de idade mínima e "pedágio".

d) Pagamento dos benefícios salário-família e auxílio-reclusão apenas aos segurados (e dependentes) de baixa renda, criando requisito novo para a concessão do benefício, qual seja, que o trabalhador tenha baixa renda. ${ }^{116}$

e) Constitucionalização do regime de Previdência Privada, a ser disciplinada por lei complementar, obedecendo aos seguintes contornos (artigo 202 da CF): (i) caráter

\footnotetext{
${ }^{114}$ Confira-se a redação do texto originário: “Art. 202. É assegurada aposentadoria, nos termos da lei, calculando-se o benefício sobre a média dos trinta e seis últimos salários de contribuição, corrigidos monetariamente mês a mês, e comprovada a regularidade dos reajustes dos salários de contribuição de modo a preservar seus valores reais e obedecidas as seguintes condições:"

115 "Art. 201, § $3^{\circ}$ Todos os salários de contribuição considerados para o cálculo de benefício serão devidamente atualizados, na forma da lei."

${ }^{116}$ De acordo com o artigo 13 da EC 20/98, "até que a lei discipline o acesso ao salário-família e auxílioreclusão para os servidores, segurados e seus dependentes, esses benefícios serão concedidos apenas àqueles que tenham renda bruta mensal igual ou inferior a $\mathrm{R} \$ 360,00$ (trezentos e sessenta reais), que, até a publicação da lei, serão corrigidos pelos mesmos índices aplicados aos benefícios gerais do regime geral de previdência social".
} 
complementar; (ii) autonomia em relação ao regime geral; (iii) facultatividade; (iv) sustentação na constituição de reservas que garantam o benefício contratado.

f) Constitucionalização de nova fonte de custeio: rendimentos do trabalho, pagos ou creditados a qualquer título, e toda e qualquer receita auferida pelo empregador (artigo 195, I, “a”).

As alterações introduzidas pela Emenda Constitucional n 20/98 mudaram a feição da Previdência Social desenhada pelo legislador constituinte de 1988, pois representaram o primeiro passo - e talvez o mais difícil, em face dos custos políticos envolvidos - para a adoção do regime de capitalização e privatização da previdência.

Em uma só tacada, desestimulou-se a aposentadoria precoce mediante a redução do valor do benefício e fincaram-se as bases para o desenvolvimento da Previdência Privada.

A Emenda $n^{\circ} 41$ andou por este mesmo caminho, agora livre em razão de as portas já estarem abertas.

\subsubsection{Emenda Constitucional $n^{\circ} 41 / 2003$}

O Presidente Lula, pouco tempo depois de assumir a Presidência da República, enviou ao Congresso Nacional o Projeto de Emenda Constitucional $\mathrm{n}^{\circ}$ 40, dando continuidade à reforma iniciada por seu antecessor e com um foco único: alterar o regime de previdência dos servidores públicos.

Sua proposta encontrou menos resistência do que aquela apresentada pelo Governo Fernando Henrique Cardoso e foi aprovada pela Emenda Constitucional $n^{\circ}$ 41/2003, veiculando as seguintes alterações:

a) Fixação de um valor teto de benefício para os servidores que ingressarem no sistema público a partir da Emenda 41, desde que seja instituído pela União, pelos Estados, Municípios e Distrito Federal um regime de previdência complementar para os servidores titulares de cargos efetivos. O teto do funcionalismo público será o mesmo teto do Regime Geral; acima de tal valor, a cobertura deve ser paga pela previdência complementar, se o servidor para ela contribuir.

Em breves palavras: os regimes próprios de Previdência do servidor público (que ingressar após a EC 41/03, com as condições acima mencionadas) são, ao mesmo tempo, de repartição simples (até o valor do teto) e de capitalização (no valor que exceder ao teto). 
b) Constitucionalização da obrigatoriedade de inclusão previdenciária "para atender a trabalhadores de baixa renda e àqueles sem renda própria que se dediquem exclusivamente ao trabalho doméstico no âmbito de sua residência, desde que pertencentes a famílias de baixa renda, garantindo-lhes acesso a benefícios de valor igual a um saláriomínimo" (artigo 201, § 12 da CF, introduzido pela Emenda Constitucional no 47/2005 mas com efeitos retroativos à data de vigência da EC 41/2003).

c) Alteração da forma de cálculo da aposentadoria, não sendo mais considerado apenas o valor da última remuneração, mas sim a média das remunerações percebidas no serviço público e eventualmente em atividade privada. A matéria foi disciplinada pela Lei ${ }^{\circ} 10.887 / 2004$.

d) Para os servidores que ingressarem no regime público a partir de 31 de dezembro de 2003 e a partir de quando forem estabelecidos os regimes de Previdência Complementar, não haverá mais paridade entre os reajustes dos ativos e dos inativos. Foram estabelecidas regras de transição para os servidores que tiverem ingressado até 31 de dezembro de 2003.

e) Criação de um redutor para o servidor que se aposentar antes de atingir a idade mínima de 55 anos (se mulher) ou 60 anos (se homem).

f) Criação, por meio de Emenda Constitucional, da contribuição dos inativos, na forma do $\S 18$ do artigo $41 \mathrm{CF}$.

g) Limitação do valor da pensão devida aos dependentes do servidor, determinando que: $(i)$ ao aposentado na data do óbito, a pensão corresponderá à totalidade dos proventos do servidor falecido, até o limite máximo estabelecido para os benefícios do Regime Geral de Previdência Social, acrescentado de $70 \%$ da parcela excedente a este limite; (ii) ao servidor em atividade na data do óbito, a pensão corresponderá ao valor da totalidade da remuneração do servidor no cargo efetivo em que se deu o falecimento, acrescentado de $70 \%$ da parcela excedente a este limite.

\subsubsection{Projeto de Emenda Constitucional no $341 / 2009$}

Por fim, nesta toada de emendas, não se pode deixar de mencionar o Projeto de Emenda Constitucional n $n^{\circ}$ 241/2009, em trâmite no Congresso Nacional. Apresentado pelo Deputado Régis de Oliveira, seu propósito é a modificação do texto constitucional, dele retirando matérias sem conteúdo constitucional, segundo a ementa inscrita no projeto. Propõe uma nova Constituição, com apenas 70 (setenta) artigos. 
Em relação à Previdência Social, é mantido o dispositivo que a considera direito social, ao lado da educação, saúde, trabalho, moradia, lazer, segurança, proteção à maternidade e à infância e assistência aos desamparados. No entanto, toda a regulamentação é delegada à lei, não havendo qualquer outra norma constitucional estabelecendo o conteúdo deste direito, como consta do texto em vigor. ${ }^{117}$

O projeto mantém as cláusulas pétreas já previstas pela Constituição Federal vigente.

De acordo com a justificativa, a Constituição deve conter apenas as normas materialmente constitucionais. Entende o Ilustre Deputado que desta forma será possível resgatar o equilíbrio entre os Poderes, permitindo que cada um exerça a sua atribuição típica.

Vejamos suas palavras:

\begin{abstract}
Ademais, há que se prestigiar o Poder Legislativo, que vive afogado em medidas provisórias que não atendem os requisitos constitucionais. Dentro de tal espírito de constrangimento do Poder Legislativo, há que se reequilibrar os poderes, darlhes atividades conjuntas de aceleração das decisões maiores da cidadania, não ficando apenas nas mãos do Executivo.

O Poder Judiciário passou a ditar políticas públicas, diante da ausência e da eficiência do Legislativo, o que deturpa as realizações efetivas das tomadas de posição.

Há o excrescente aumento de competências "inconstitucionais" do Executivo, por força de suas atribuições de distribuição de emendas constitucionais e cargos administrativos. (...).
\end{abstract}

Vemos com bastante receio as alterações que se pretendem introduzir.

Se é certo que o texto constitucional não deve conter políticas de Governo que engessem os órgãos públicos responsáveis pela sua elaboração e execução, também é certo que, para além de estabelecer os direitos que reputa fundamentais, é necessário indicar os contornos desses direitos, fornecendo ao legislador infraconstitucional os parâmetros a serem adotados quando da formulação das políticas públicas. Vale dizer, devem conter do texto constitucional as diretrizes gerais do sistema previdenciário, indicando qual a política de Estado delineada.

\footnotetext{
${ }^{117}$ Esta intenção já parecia estar presente na equipe do governo de Fernando Henrique Cardoso, ao promover a Reforma de 1998, verbis: "Vale observar que a tentativa de desconstitucionalização baseou-se na experiência universal, que mostra que a maior parte dos países destina dois ou três itens em suas Constituições para a matéria previdenciária, deixando o detalhamento para a lei. No Brasil, contudo, a Constituição de 1988 contempla mais de 80 itens, muitos dos quais poderiam ser definidos em leis, decretos e mesmo em normas internas. Apesar disso, a nova proposta, com as alterações sofridas durante a sua tramitação, ainda é mais constitucionalizada do que a anterior. E, se por um lado, desejava-se dar maior garantia à população, por outro, criou-se uma dificuldade de adaptação do sistema a cenários futuros, ou seja, qualquer ajuste dependerá de nova Emenda Constitucional” (STEPHANES, Reinhold. Op. cit., p. 142).
} 
Assim, a afirmação de que a previdência social é um direito social (ressalte-se que não há menção no projeto a direito fundamental), a ser disciplinado por lei, nada mais é do que uma frase vazia. A inexistência de regras e princípios fixando o conteúdo deste direito outorga ao legislador infraconstitucional um verdadeiro "cheque em branco", sem qualquer responsabilidade pelo que vier a fazer, já que não imposto parâmetro algum.

Acreditamos não haver uma única resposta certa e definitiva sobre o melhor regime de previdência. No entanto, concordamos com José Neves ao afirmar que "uma coisa porém é certa: se houver alguma solução, o Estado é que terá de encontrá-la. A responsabilidade é dele e não da iniciativa privada, que não existe para isso nem tem condições para tanto. Então não tem sentido a ideia da privatização da previdência social". 118

Nos termos em que redigidos, o projeto de Emenda Constitucional $n^{\mathbf{o}}$ 341/09 possibilita a privatização da Previdência Social pela legislação infraconstitucional, pois em momento algum atribui ao Estado qualquer atribuição na sua realização.

\subsubsection{Dois outros significativos exemplos da influência neoliberal na} Constituição Federal: o equilíbrio financeiro e atuarial e a desvinculação das receitas da União

\subsection{Equilíbrio financeiro e atuarial}

Por força da Emenda Constitucional n ${ }^{\circ}$ 20/1998, foi alterado o caput do artigo 201 da Constituição Federal, passando a vigorar com o seguinte teor:

Art. 201. A previdência social será organizada sob a forma de regime geral, de caráter contributivo e de filiação obrigatória, observados critérios que preservem o equilíbrio financeiro e atuarial, e atenderá, nos termos da lei, a: (...)" - grifos meus.

Também foi introduzido no texto constitucional o artigo 250, verbis:

Art. 250. Com o objetivo de assegurar recursos para o pagamento dos benefícios concedidos pelo regime geral de previdência social, em adição aos recursos de sua arrecadação, a União poderá constituir fundo integrado por bens, direitos e

\footnotetext{
${ }^{118}$ NEVES, José. Privatização da Previdência Social: nove equívocos e uma incógnita. In CÉSAR, Afonso. A
} face oculta e cruel da reforma da Previdência. Brasília: Cedil, 1995. p. 59. 
ativos de qualquer natureza, mediante lei que disporá sobre a natureza e administração desse fundo. ${ }^{119}$

Uma breve análise histórica das finanças públicas dos países, entre os quais o Brasil, demonstra que o equilíbrio orçamentário não é um direito fundamental, mas sim uma forma de gestão do dinheiro público, vale dizer, é uma opção expressa do Poder Público, a ser adotada se e quando entender conveniente.

De acordo com o relato de Aliomar Baleeiro, até a eclosão da Primeira Guerra Mundial, o equilíbrio orçamentário era a "regra de ouro das finanças públicas". A partir daí, em face dos graves prejuízos advindos, os Estados foram obrigados a gastar mais a fim de se recuperarem dos efeitos da crise. Perderam, então, "o complexo de culpa em relação ao déficit'. Acostumaram-se a esse fato e tiveram provas concretas de que ele, ao invés de consequências catastróficas, poderia gerar, em certas circunstâncias, melhores condições de vida para o País. Conclui, assim, que "o equilíbrio orçamentário é desejável em certos casos. Pode ser impossível e inelutável em outros. E será nocivo em circunstâncias especiais" $^{120}$ (grifos do Autor).

A análise das finanças públicas brasileiras atesta que no período compreendido entre 1890 e 1973, ou seja, em 83 exercícios, houve superávit em 15 e déficit nos outros $68 .^{121}$

Tais fatos comprovam que o equilíbrio financeiro pode ou não ser uma meta a ser alcançada, "o problema é de oportunidade e rigor de apreciação da conjuntura". ${ }^{122}$

Visando sanear os gastos públicos e corrigir as distorções do regime previdenciário, a opção política tomada pelo Governo consistiu na adoção de um modelo essencialmente contributivo e que deve buscar o equilíbrio financeiro e atuarial.

O atual déficit da Previdência é atribuído por alguns economistas e pelo próprio Governo às aposentadorias rurais. ${ }^{123}$

\footnotetext{
${ }^{119}$ O Fundo do Regime Geral de Previdência Social foi regulamentado pela Lei de Responsabilidade Fiscal (Lei Complementar 101/2000).

${ }^{120}$ BALEEIRO, Aliomar. Uma introdução à ciência das finanças. 15. ed., rev. e atual. Rio de Janeiro: Forense, 1998. p. 425-427.

${ }^{121}$ Idem, ibidem, p. 427.

${ }^{122}$ Idem, ibidem, p. 428.

${ }^{123} \mathrm{Na}$ nota de rodapé 194 de seu livro (O orçamento da Seguridade Social e a efetividade dos direitos sociais. Curitiba: Juruá, 2009. p. 163), Ricardo Pires Calciolari apresenta trecho do artigo escrito por Cristian Jungblut (http://oglobo.globo.com/pais/mat/2009/01/09/levantamento-mostra-que-aposentadorias-rurais-quenao-contribuem-com-previdencia-representaram-35-dos-benefícios-em-2008-591616298.asp) que bem demonstra o teor das críticas lançadas: "A distorção fica clara ao se verificar os gastos da Previdência: o sistema rural corresponde a apenas $19,7 \%$ da despesa total de $\mathrm{R} \$ 182,5$ bilhões do setor no ano, mas, em contrapartida, é o maior responsável pelo déficit do sistema geral. A despesa com benefícios rurais chegou a $\mathrm{R}$ \$ 36,6 bilhões em 2008, com uma arrecadação de apenas R \$ 4,6 bilhões, segundo dados fechados em
} 
No entanto, a Constituição Federal de 1988 determinou expressamente que a uniformidade e a equivalência dos benefícios e serviços às populações urbanas e rurais é um dos objetivos a serem perseguidos pela Seguridade Social (CFR, artigo 194, parágrafo único, II), como também não é correto afirmar que os trabalhadores rurais nunca contribuíram, vez que, nos termos da legislação anterior (Lei Complementar n $n^{\circ} 11 / 71$ ), era devida contribuição pelo rurícola, incidente sobre a comercialização dos produtos rurais.

Uma análise pormenorizada revela que parte das receitas do orçamento da Seguridade Social é utilizada para pagamento de benefícios devidos a servidores inativos da União, bem como a salários dos servidores ativos da União. Ora, por força da própria Constituição Federal os servidores públicos - ativos e inativos - estão submetidos a um regime próprio de Previdência Social (artigo 40), sendo indevido o pagamento de benefícios com recursos arrecadados pelo regime geral, como adverte Ricardo Pires Calciolari:

\begin{abstract}
O regime de previdência próprio dos servidores é exposto pelo art. 40 da Constituição de 1988, deixando claro que as disposições relativas ao Regime Geral de Previdência Social serão aplicadas aos servidores públicos apenas subsidiariamente (art. $40, \S 12$, da Constituição, com a redação dada pela Emenda 20, de 15.12.1998). Assim, verificamos que o regime jurídico da previdência do regime próprio e do regime geral são diversos. Desse modo, devemos concluir que o sistema de Seguridade Social não abrange a previdência dos regimes próprios dos diversos Estados-membros, Municípios, Distrito Federal e União. Sendo assim, não poderia ser computado como despesa da Seguridade Social o custeio dos benéficos previdenciários dos inativos da União, pois, além de atacar a boa hermenêutica dos dispositivos constitucionais citados, ofende a lógica do federalismo cooperativo (...). ${ }^{124}$
\end{abstract}

Parte da doutrina aponta como causa do déficit o financiamento intergeracional ${ }^{125}$, sendo de rigor obstar a inércia dos poderes competentes, incitando-os a tomar as medidas necessárias e adequadas para resolver a questão, especialmente, a observância da vinculação determinada constitucionalmente. ${ }^{126}$ Confira-se:

novembro. Em 2008, de todos os tipos de benefícios concedidos pela Previdência, os rurais representaram quase um terço: foram 4,11 milhões de benefícios, sendo 3,15 milhões urbanos e 965,8 mil rurais. O rombo tem origem em 1988, quando a Constituição criou regras especiais para as aposentadorias rurais, sem exigir contribuição direta, como no caso do trabalhador urbano. Para obter o benefício, basta o trabalhador ou agricultor demonstrar que está exercendo a atividade rural na data de entrada do requerimento. E mais: a aposentadoria rural é concedida aos 60 anos, para os homens, e aos 55 para as mulheres, cinco anos a menos do que na regra geral".

${ }^{124}$ CALCIOLARI, Ricardo Pires. Op. cit., 2009, p. 154-155.

${ }^{125}$ Cite-se, por exemplo, Ricardo Pires Calciolari, Fábio Adriano Miessi Sanches, entre outros.

${ }^{126}$ CALCIOLARI, Ricardo. Op. cit., 2009, p. 166. 
Os números utilizados para avaliar a situação financeira da Previdência são normalmente enganosos e alarmistas. Divulga-se que o déficit previdenciário, em 2005, foi de $\mathrm{R} \$ 37,6$ bilhões e, em 2006, de R $\$ 42$ bilhões. O que tem sido chamado de déficit da Previdência é, entretanto, o saldo previdenciário negativo, ou seja, a soma de receitas das contribuições ao INSS sobre a folha de salários e demais rendimentos do trabalho deduzidas dos benefícios previdenciários do RGPS. Esse cálculo não leva em consideração todas as receitas que devem ser alocadas para a Previdência Social, conforme estabelece o artigo 195 da Constituição Federal de 1988, que versa sobre o orçamento próprio e exclusivo da seguridade social. Deixam-se de computar recursos significativos provenientes da Cofins, CPMF, CSLL e receita de concursos de prognóstico. Essas receitas financiam a saúde, assistência social e também a Previdência. Sem incluí-las no cálculo, o resultado fere os princípios constitucionais e resulta num déficit irreal. Se computada a totalidade das fontes de recurso que cabem à Previdência, conforme disposto na Carta Magna, e deduzida a despesa total inclusive com pessoal, custeio, dívida do setor e gastos não previdenciários, o resultado apurado será um superávit de R 921 milhões em 2005 e R \$ 1,2 bilhão em 2006 (...). Houve superávit em todos os últimos sete anos, com exceção de 2003. Esse superávit, denominado superávit operacional, uma informação favorável ao sistema público de previdência, não é, entretanto, divulgado para a população como sendo o resultado da Previdência Social. ${ }^{127}$

Ao apresentar seu voto no julgamento da ADIN n ${ }^{\circ} 3.105-8 / \mathrm{DF}^{128}$, o Ministro Carlos Britto aponta para a mesma direção:

Agora, do ângulo do Poder Público, exclusivamente, o dispositivo constitucional em causa (art. 40, caput) estabeleceu que a Previdência Social deverá ser organizada com observância de critérios que preservem o equilíbrio financeiro e atuarial do sistema. É deduzir: cabe ao Poder Público, enquanto exclusivo gestor das verbas arrecadadas, fazê-las render o suficiente para assegurar a continuidade vitalícia dos benefícios que são próprios do sistema; estabelecendo, para tanto, uma política de número de funcionários, fixação de base de cálculo e de percentual de descontos previdenciários o bastante para o alcance perene daquele patamar de autossuficiência financeira.

Ou seja, a questão do equilíbrio atuarial e financeiro não diz respeito ao servidor, diz respeito ao gerente. Compete ao gerente administrar a arrecadação de recursos para fazê-los render o suficiente para a autossustentação financeira do sistema. Não interessa ao servidor, mas, sim, ao gerente. Quero dizer que, muitas vezes, a questão da Previdência, quando se fala em déficit, Sra. Relatora, não é uma questão de Previdência, porém de providência, providência gerencial do Poder Público. Tanto assim, o sistema é teoricamente rentável e autossuficiente que o mercado previdenciário privado experimenta o maior assanhamento para abocanhar uma fatia desse mercado promissor.

E os fundos de pensão, que nadam em dinheiro, evidenciam que o sistema é rentável, é autossustentável.

${ }^{127}$ GENTIL, Denise Lobato. A política fiscal e a falsa crise do sistema de seguridade social no Brasil: análise financeira do período recente. In SICSÚ, João (org.). Arrecadação (de onde vem?) e gastos públicos (para onde vão?). São Paulo: Boitempo, 2007. p. 30.

${ }^{128}$ A decisão foi publicada no Diário da Justiça de 18/02/2005. 


\subsection{Desvinculação das Receitas da União}

Outra manifestação da influência neoliberal é a inserção, no texto constitucional, da medida de desvinculação de receitas da União (DRU).

Por meio da Emenda Constitucional de Revisão n ${ }^{\circ}$ 1, de 31/03/1994, foi criado o Fundo Social de Emergência, instituído nos exercícios financeiros de 1994 e 1995, com o objetivo de sanear as contas da Fazenda Pública Federal e de estabilização econômica, cujos recursos serão aplicados no custeio das ações dos sistemas de saúde e educação, benefícios previdenciários e auxílios assistenciais de prestação continuada, inclusive liquidação de passivo previdenciário, e outros programas de relevante interesse econômico.

Uma das receitas que integravam o Fundo era constituída de $20 \%$ (vinte por cento) do produto da arrecadação de todos os impostos e contribuições da União.

Por força das Emendas Constitucionais ns. 10/1996 e 17/1997, o Fundo passou a ser denominado Fundo de Estabilização Fiscal e foi ampliada a desvinculação das receitas para também incluir os tributos já instituídos e os que vierem a ser instituídos, com vigência até 31/12/1999.

Foi então promulgada a Emenda Constitucional n 27/2000, introduzindo o artigo 76 ao Ato das Disposições Constitucionais Transitórias, do seguinte teor:

\footnotetext{
Art. 76. É desvinculado de órgão, fundo ou despesa, no período de 2003 a 2007, vinte por cento da arrecadação da União de impostos, contribuições sociais e de intervenção no domínio econômico, já instituídos ou que vierem a ser criados no referido período, seus adicionais e respectivos aspectos legais.

$\S 1^{\circ} \mathrm{O}$ disposto no caput deste artigo não reduzirá a base de cálculo das transferências a Estados, Distrito Federal e Municípios na forma dos arts. 153, § $5^{\circ}$; 157, I; 158, I e II; e 159, I, $a$ e $b$; e II, da Constituição, bem como a base de cálculo das destinações a que se refere o art. 159, I, $c$, da Constituição.

$\S 2^{\circ}$ Excetua-se da desvinculação de que trata o caput deste artigo a arrecadação da contribuição social do salário-educação a que se refere o art. 212 , $\S 5^{\circ}$, da Constituição.
}

Por fim, a Emenda Constitucional n ${ }^{\circ}$ 56/2007 prorrogou a DRU - Desvinculação de Rendas da União - até 31/12/2011.

Desde o ano de 1994, portanto, vinte por cento do orçamento da Seguridade Social é desvinculado de sua finalidade específica e utilizado para sanear as contas da União Federal.

A previsão de um orçamento específico da Seguridade Social foi estabelecida pelo legislador constituinte originário como a fonte de custeio adequada e necessária para arcar 
com o pagamento dos direitos previdenciários, de saúde e de assistência social assegurados, dando concretude ao disposto no $\S 5^{\circ}$ do artigo 195.

Por força do artigo 167, XI, da Constituição Federal ${ }^{129}$, os recursos arrecadados com fundamento no artigo 195 , I, $a$, e II, da $\mathrm{CFR}^{130}$ não podem ser desvinculados e utilizados em finalidade diversa do pagamento dos benefícios. Portanto, não ingressam no montante de $20 \%$ correspondente à DRU.

Para os fins do presente trabalho, limitado à análise das políticas públicas previdenciárias, não será dada ênfase ao estudo da DRU, em face da impossibilidade de desvinculação dos recursos destinados ao pagamento dos benefícios do Regime Geral de Previdência Social.

No entanto, especialmente aos operadores do Direito é de suma importância saber que alegações sobre o tão falado déficit da Previdência devem ser analisadas de forma diversa daquelas que apontam o déficit da Seguridade Social ${ }^{131}$.

No primeiro caso, deve ser observado se os recursos arrecadados com fundamento no artigo 195, I, $a$, e II, da CFR foram efetivamente utilizados para o pagamento de benefícios previdenciários do Regime Geral. No segundo caso, o ponto de partida é a análise da constitucionalidade da DRU ${ }^{132} 133$ e a seguir dos efeitos de sua incidência. ${ }^{134}$

129 “Art. 167 - São vedados:

(...)

XI - a utilização dos recursos provenientes das contribuições sociais de que trata o art. 195, I, $a$, e II, para a realização de despesas distintas do pagamento de benefícios do regime geral de previdência social de que trata o art. 201."”

130 “Art. 195. A seguridade social será financiada por toda a sociedade, de forma direta e indireta, nos termos da lei, mediante recursos provenientes dos orçamentos da União, dos Estados, do Distrito Federal e dos Municípios, e das seguintes contribuições sociais:

I - do empregador, da empresa e da entidade a ela equiparada na forma da lei, incidentes sobre:

a) A folha de salários e demais rendimentos do trabalho pagos ou creditados, a qualquer título, à pessoa física que lhe preste serviço, mesmo sem víncullo empregatício;

b) (...)

II - do trabalhador e dos demais segurados da previdência social, não incidindo contribuição sobre aposentadoria e pensão concedidas pelo regime geral de previdência social de que trata o art. 201; (...)"

${ }^{131}$ Bastante comum quando se alega, por exemplo, a inexistência de recursos para o pagamento de remédios ou serviços de saúde.

${ }^{132}$ Em sua dissertação de mestrado ("As leis orçamentárias como instrumento de implantação dos direitos fundamentais sociais), Sandoval Alves da Silva afirma que a desvinculação das receitas altera a natureza jurídica das contribuições sociais (que são tributos criados com uma finalidade específica), igualando-as aos impostos, sem contudo submetê-las ao sistema de repartição de receitas determinado pelos artigos 153 , $\S 5^{\circ}$, 157,158 e 159 da Constituição Federal.

${ }^{133}$ Também se questiona a constitucionalidade da desvinculação estabelecida pela EC 56/2007 na medida em que o artigo 76 do ADCT, por ela introduzido, não apresenta qualquer finalidade a ser perseguida com os recursos desviados, o que não ocorria com os antigos Fundo Social de Emergência (criado pela Emenda de Revisão $n^{\circ}$ 1/94) e Fundo de Estabilização Fiscal (criado pela Emenda $n^{0}$ 10/96), cujos objetivos expressos eram o saneamento financeiro da União e a aplicação prioritária a despesas associadas a programas de relevante interesse econômico e social. 
A DRU é um ótimo exemplo de como razões de ordem econômica acabam se sobrepondo aos direitos anteriormente existentes e de como os apelos econômicos são aceitos, no mais das vezes, como premissas absolutas e incontestáveis.

Parece haver um paradoxo entre a desvinculação das receitas da União (DRU) e o discurso que prega o déficit do sistema de seguridade social, pois não há como ceder algo que não se possui. Se o sistema não gera sobras - e esta é a justificativa utilizada para a promoção das reformas -, o que pode então ser desvinculado?

\subsubsection{Limites possíveis das reformas previdenciárias}

Quando afirmamos que o direito fundamental à previdência social está assegurado por cláusula pétrea (CFR, artigo 60, $\S 4^{\circ}$ ), isto significa que todas as normas constitucionais constantes do texto originário e que estabelecem o conteúdo deste direito não podem ser suprimidas ou reduzidas por obra do legislador posterior, ainda que por meio de Emenda Constitucional. Significa, também, que alterações posteriores podem e devem ocorrer quando necessário, desde que não impliquem retrocesso social.

Portanto, as normas originárias - consubstanciadas em regras e princípios constituem o patamar mínimo do direito fundamental em tela.

No entanto, a experiência brasileira demonstra que, em matéria previdenciária, o texto constitucional tem sido reiteradamente modificado em sentido inverso ao desejado. De acordo com Leda Paulani, "a combinação dessas duas emendas constitucionais trará, no médio prazo, uma mudança substantiva na feição do sistema previdenciário brasileiro, uma vez que o regime de capitalização ganhará um espaço cada vez maior e passará a dar a tônica desse sistema". ${ }^{135}$

Em alguns casos, o meio utilizado é a desconstitucionalização da norma fundamental, sendo delegada ao legislador infraconstitucional a competência para disciplinar a matéria, tornando menos visível e desgastante a mudança que se pretende.

Em outras hipóteses, é dada nova redação ao texto constitucional, mediante a inserção das normas necessárias a possibilitar a concretização das novas diretrizes.

\footnotetext{
${ }^{134}$ De acordo com Ricardo Pires Calciolari, "comparando o total arrecadado a título de contribuições sociais e os gastos realizados com a seguridade social verificaremos que, nos anos de 2005 e 2006, sem a desvinculação dos vinte por cento (DRU), temos que a seguridade social foi claramente superavitária" (A crise de efetividade dos direitos sociais e a desvinculação de receitas. In ROCHA, Daniel Machado da; SAVARIS, José Antonio (coords.). Curso de Especialização em Direito Previdenciário - volume 3 Custeio da Seguridade Social. Curitiba: Juruá Editora, 2008. p. 65).

${ }^{135}$ PAULANI, Leda Maria. Seguridade Social, Regimes Previdenciários e Padrão de Acumulação: uma nota teórica e uma reflexão sobre o Brasil. In $O p$. cit., p. 28.
} 
Seja qual for o meio utilizado, a razão que impulsiona a alteração é quase sempre a eficiência econômica e não o aumento do nível de bem-estar social. Segundo Maria Paula Dallari Bucci,

em nome da manutenção do equilíbrio fiscal do Estado, propõe-se a redução dos direitos, muitas vezes apresentados como privilégios ou direitos imerecidos. Em determinadas situações, pode, realmente, haver privilégio, que se manifestaria num direito carente de fundamento moral. Isso, todavia, não justifica as políticas de austeridade dos Estado às custas das garantias sociais cuja supressão atinge duramente os mais pobres. ${ }^{136}$

Ao analisar as reformas previdenciárias ocorridas a partir dos anos 80 na América Latina, Gosta Esping-Andersen chega a duas conclusões:

Primeiro, a privatização previdenciária latino-americana foi lançada como um meio de corrigir males econômicos. Isso parece muito similar a matar o mensageiro que traz más notícias. Como indica a discussão anterior, é improvável que se obtenha a partir dessas reformas algum equilíbrio mais adequado, a menos que as políticas também ataquem o outro lado da moeda, o mercado de trabalho. Segundo, o processo da reforma previdenciária na América Latina diz respeito principalmente à poupança e aos déficits, mas muito pouco à segurança na velhice. É altamente improvável que um regime previdenciário privado venha a ser um sistema capaz de oferecer segurança efetiva na velhice. Assim, supondo que venhamos a ter no futuro uma democracia estável, então sem dúvida assistiremos a uma nova onda de debates sobre política previdenciária, e muito provavelmente esses debates serão principalmente sobre segurança na velhice e muito pouco sobre taxas de poupança. ${ }^{137}$

Talvez a solução para a agenda alternativa seja a mudança do foco das despesas para o das receitas, como sugere Eduardo Fagnani. Segundo o autor,

a natureza da questão do financiamento da Previdência Social é preponderantemente exógena e reflete as opções macroeconômicas adotadas nas últimas décadas, que fragilizaram o mercado de trabalho e estreitaram os mecanismos de financiamento das políticas sociais, em geral, e da Previdência Social, em particular. Mais precisamente, o cerne da questão do financiamento da Seguridade Social é a redução do patamar de receitas, decorrente do baixo crescimento econômico e seus impactos negativos sobre o mercado de trabalho. $^{138}$

Várias são as discussões e várias são as alternativas possíveis.

\footnotetext{
${ }^{136}$ BUCCI, Maria Paula Dallari. Revista cit., 1995, p. 117.

137 "ESPING-ANDERSEN, Gosta. "Uma perspectiva transatlântica da política de privatização latinoamericana”. In COELHO, Vera Schattan P. (org.). A Reforma da Previdência Social na América Latina. Rio de Janeiro: Editora FGV, 2003. p. 25.

138 FAGNANI, Eduardo. Previdência social e desenvolvimento econômico. Texto para discussão. IE/UNICAMP, Campinas, no 140, fev. 2008, p. 23.
} 
O regime democrático não permite, ao menos teoricamente, que mudanças drásticas e restritivas de direitos sejam introduzidas na ordem jurídica sem o respaldo da maioria. A tarefa que se põe então é ocupar o espaço de decisão e controle que lhe foi atribuído e que está sendo inconstitucionalmente ocupado por outrem.

Mudanças são possíveis e necessárias, inclusive para o aperfeiçoamento da democracia. Mas como alerta o Professor Marcus Orione Gonçalves Correia "somente existe Estado democrático de direito onde há plena efetivação dos direitos sociais insculpidos constitucionalmente". ${ }^{139}$ Portanto, qualquer alteração promovida pelo Poder constituinte derivado não pode importar em redução ou qualquer forma de não realização dos direitos sociais, vez que essenciais à própria caracterização do Estado democrático de direito, cujo objetivo é promover a diminuição da desigualdade e a erradicação da pobreza.

Ressalte-se que as reformas realizadas em 1998 e 2003, apesar de terem inserido no texto constitucional alguns institutos típicos do modelo neoliberal, não tornaram letra morta as disposições originárias que acenavam para a realização de um Estado de BemEstar no Brasil, vez que protegidas por cláusula pétrea, de maneira que atualmente a Constituição encontra-se permeada por normas dos dois modelos. ${ }^{140}$

Fundamental, então, a transparência das inovações e dos motivos que a ensejam para que o debate entre as categorias envolvidas não gire em torno de falácias e se atenha, essencialmente, ao nível de melhoria do bem-estar proporcionado com a reforma que se quer fazer. Este, sim, é o motor que deve engrenar as mudanças.

As decisões políticas tomadas na esfera própria, ao serem incorporadas no ordenamento jurídico, assumem a forma de princípios e regras e podem restringir o direito fundamental a que se referem. Embora passem pelo teste inicial da constitucionalidade, sendo recepcionadas pela ordem já existente, sua aplicação está sujeita, caso a caso, ao sopesamento com os demais princípios, não se sobrepondo de antemão a qualquer um deles. Desta forma, quando a Emenda Constitucional $n^{\circ}$ 20/1998 inseriu o princípio do equilíbrio financeiro e atuarial no sistema de previdência social não invalidou os demais princípios já existentes, mas trouxe ao órgão julgador mais um, a ser sopesado em caso de eventual conflito, aplicando, no caso concreto, o que se mostrar mais pertinente. ${ }^{141}$

\footnotetext{
${ }^{139}$ CORREIA, Marcus Orione Gonçalves. Teoria e Prática do Poder de Ação na Defesa dos Direitos Sociais. São Paulo: LTr, 2002. p. 9.

${ }^{140}$ Acrescente-se que usualmente surgem situações de conflito, a serem solucionadas pelo órgão judicial através da técnica da ponderação, como será desenvolvido no Capítulo 2.

${ }^{141}$ Os parâmetros utilizados pelo Poder Judiciário são tratados no Capítulo 2.
} 


\title{
1.6. Políticas públicas previdenciárias
}

\subsubsection{Política de Estado}

Como visto nas linhas acima, o conteúdo do direito fundamental à previdência social é apreendido de diversos dispositivos constitucionais ${ }^{142}$ e deve ser realizado de acordo com as diretrizes firmadas no texto constitucional e disciplinadas pela legislação infraconstitucional, especialmente as Leis ns. 8.212/91 (Lei de Custeio) e 8.213/91 (Lei de Benefícios).

De acordo com a premissa firmada no início deste Capítulo, tais diretrizes constitucionais e referidos atos normativos legais integram a política de Estado em matéria previdenciária e visam dar efetividade ao direito fundamental.

Dada a extensão do tema, não iremos analisar os dispositivos um a um, como também não consideramos possível afirmar que a Lei nº 8.213/91, de forma geral, realiza o conteúdo do direito fundamental à previdência social em toda a sua extensão, na medida em que ela contém 156 (cento e cinquenta e seis) artigos, alguns deles mantendo a redação originária e outros por diversas vezes alterados; alguns constitucionais e outros não. $\mathrm{O}$ mesmo se diz em relação à Lei $n^{\circ} 8.212$, com seus 105 (cento e cinco) artigos.

Tanto a Lei $\mathrm{n}^{\circ} 8.212$ como a Lei $\mathrm{n}^{\circ} 8.213$ não são, na essência, políticas de Governo, na medida em que não apresentam como "arranjos institucionais complexos, expressos em estratégias ou programas de ação governamental, que resultam de processos

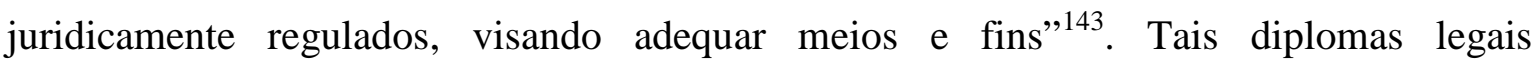
regulamentam as disposições constitucionais e fornecem os elementos necessários para que sejam elaboradas as políticas de Governo.

Ressalte-se que ambas contêm a expressão "plano" (de Custeio - Lei no 8.212 - e de Benefícios - Lei nº 8.213/91).

Plano, para o Professor Eros Grau, é espécie de norma-objetivo, em que

\begin{abstract}
não há nem comportamento, nem estrutura e funcionamento de órgão ou disciplina de processo técnico de identificação e aplicação de outras normas sendo regulados; pelo contrário, nelas se estabelece uma obrigação de resultado, deixando-se porém aos seus destinatários a opção pelos meios e formas de comportamento a dinamizar, na busca de sua realização. É o seu conceito, sem
\end{abstract}

\footnotetext{
${ }^{142}$ Sem prejuízo das normas inscritas em tratados internacionais de que o Brasil seja parte, nos termos do $\S 2^{\circ}$ do artigo $5^{\circ}$ da Constituição Federal.

${ }^{143}$ Confira-se o artigo de BUCCI, Maria Paula Dallari. "Notas para uma metodologia jurídica de análise de políticas públicas”. In Op. cit., p. 251).
} 
dúvida, que mais se amolda às situações de normação prospectiva, visto como nelas se definem obrigações de resultado e não de meios. ${ }^{144}$

O Professor Gilberto Bercovici, por sua vez, aponta a questão ideológica contida no plano. Define-o como

a expressão da política geral do Estado. É mais do que um programa, é um ato de direção política, pois determina a vontade estatal por meio de um conjunto de medidas coordenadas, não podendo limitar-se à mera enumeração de reivindicações. E por ser expressão desta vontade estatal, o plano deve estar de acordo com a ideologia constitucional adotada. ${ }^{145}$

O plano é a concretização do planejamento. Neste sentido, as políticas públicas em sentido estrito (políticas de Governo) são, "microplanos ou planos pontuais, que visam a racionalização técnica da ação do Poder Público para a realização de objetivos determinados, com a obtenção de certos resultados". ${ }^{146}$

Pelas razões expostas, selecionamos alguns casos práticos relativos à política de Estado e deles iremos tratar no Capítulo 3, demonstrando como o Poder Judiciário tem interpretado os atos normativos que cuidam da matéria previdenciária em cotejo com o direito fundamental que se busca efetivar.

\subsubsection{Políticas de Governo}

Considerando o conceito de políticas de Governo adotado para os fins deste trabalho, não vislumbramos no texto constitucional nenhum dispositivo em matéria previdenciária que inclua todas estas proposições.

Tal constatação também se faz sentir na análise das Leis ns. 8.212 e 8.213 que, ao regulamentarem as diretrizes inscritas na Constituição Federal, assumem, no sistema jurídico, feição permanente, característica que as afasta do conceito de políticas de Governo, na medida em que não buscam atingir um objetivo num determinado prazo, através de ações coordenadas.

Apenas para fins exemplificativos, selecionamos uma política pública previdenciária de Governo, cujas bases estão indicadas pelo artigo 88 da Lei n ${ }^{\circ} 8.213 / 91$ e

\footnotetext{
${ }^{144}$ GRAU, Eros Roberto. Planejamento econômico e regra jurídica. São Paulo: Revista dos Tribunais, 1977. p. 243.

145 Planejamento e políticas públicas: por uma nova compreensão do papel do Estado. In BUCCI, Maria Paula Dallari (org.).Op. cit., p. 145.

${ }^{146}$ BUCCI, Maria Paula Dallari. O conceito de política pública em direito. In BUCCI, Maria Paula Dallari (org.). Op. cit., p. 27.
} 
pelo artigo 161 do Decreto $n^{\circ} 3.048 / 99$ e a regulamentação é dada pelos artigos 411/413 da Instrução Normativa INSS/PRES $\mathrm{n}^{\circ}$ 20, de 10/10/2007 (publicada no DOU de 11/10/2007): trata-se da política de serviço social. Vejamos a redação do artigo 88 da Lei $n^{\circ} 8.213 / 91$ :

\begin{abstract}
Art. 88. Compete ao Serviço Social esclarecer junto aos beneficiários seus direitos sociais e os meios de exercê-los e estabelecer conjuntamente com eles o processo de solução dos problemas que emergirem da sua relação com a Previdência Social, tanto no âmbito interno da instituição como na dinâmica da sociedade.

$\S 1^{\circ}$ Será dada prioridade aos segurados em benefício por incapacidade temporária e em atendimento especial aos aposentados e pensionistas.

$\S 2^{\circ}$ Para assegurar o efetivo atendimento dos usuários serão utilizadas intervenção técnica, assistência de natureza jurídica, ajuda material, recursos sociais, intercâmbio com empresas e pesquisa social, inclusive mediante celebração de convênios, acordos ou contratos.

$\S 3^{\circ} \mathrm{O}$ Serviço Social terá como diretriz a participação do beneficiário na implementação e no fortalecimento da política previdenciária, em articulação com as associações e entidades de classe.

$\S 4^{\circ}$ O Serviço Social, considerando a universalização da Previdência Social, prestará assessoramento técnico aos Estados e Municípios na elaboração e implantação de suas propostas de trabalho.
\end{abstract}

Os demais atos normativos mencionados estabelecem, além dos objetivos e diretrizes fixados pela lei, os recursos técnicos a serem utilizados (artigo 413 da Instrução $20^{147}$ ), possibilitando a celebração de convênios, acordos ou contratos para a consecução dos objetivos.

A presença destes elementos (objetivos, diretrizes, instrumentos, planos, programas e projetos, prazo) permite que, caso a caso, seja identificada a política de Governo.

Tratamos, até aqui, do panorama geral do direito fundamental à Previdência Social, buscando suas raízes no texto constitucional e sua efetiva concretização nas políticas públicas editadas pelo legislador infraconstitucional.

Vencida esta etapa, cuidaremos agora de estabelecer os pressupostos e limites do controle judicial de políticas públicas para que no Capítulo 3, finalmente, possamos verificar como tal controle tem sido feito no caso das políticas públicas previdenciárias.

147 “Art. 413. Os recursos técnicos utilizados pelo Assistente Social são, entre outros, o parecer social, a pesquisa social e o cadastro das organizações da sociedade". 


\section{O PODER JUDICIÁRIO}

A Constituição Federal de 1988, ao lado de estabelecer um extenso rol de direitos (individuais e sociais) e garantias fundamentais, outorgou ao Poder Judiciário o poderdever de resolver todas as questões envolvendo lesão ou ameaça de lesão a direito (artigo $5^{\circ}$, inciso $\mathrm{XXXV}$ ), dispondo sobre os instrumentos processuais a serem utilizados em caso de inércia dos demais Poderes. De forma expressa, qualificou-o como um dos Poderes de Estado, ao lado do Executivo e do Legislativo, assegurando sua independência e a convivência harmônica com os demais.

Considerando a diversidade das matérias tratadas no texto constitucional e a ampliação do rol de atribuições do Judiciário, é difícil imaginar alguma questão, envolvendo interesses públicos ou de natureza meramente privada, que não esteja sujeita à apreciação judicial.

Torna-se imperativo, assim, estabelecer os limites da atuação jurisdicional, matéria que a cada dia tem sido objeto de mais estudos e controvérsias.

O presente capítulo busca identificar as principais características do Poder Judiciário enquanto Poder da República e as balizas que norteiam sua atuação no controle dos atos praticados pelos demais Poderes, especialmente as políticas públicas.

\subsection{O Judiciário como Poder de Estado}

Apenas com o advento da Constituição Federal de 1988 é que o Poder Judiciário foi reconhecido, formal e materialmente, como Poder independente, sendo-lhe conferida autonomia financeira e administrativa.

Desde a Carta do Império, com algumas poucas exceções ${ }^{148}$, a qualificação do Judiciário como Poder era meramente formal, vez que na prática quem dizia o que diriam os juízes era o Chefe do Poder Executivo.

\footnotetext{
148 Cite-se, por exemplo, a Constituição de 1946, que deu início a um processo de autonomia do Poder Judiciário, assegurando-se aos seus membros as garantias institucionais da vitaliciedade, inamovibilidade e irredutibilidade dos vencimentos. A Justiça Eleitoral, extinta pela Constituição de 1937, foi reintroduzida, a Justiça do Trabalho passou a ser tratada no texto constitucional e foi criado o Tribunal Federal de Recursos (TFR), órgão de segundo grau com competência para analisar as causas de interesse da União.
} 
A partir da nova ordem instaurada em 05/10/1988, as funções do Supremo Tribunal Federal foram redefinidas e foi criado o Superior Tribunal de Justiça, com competência para decidir as causas envolvendo questões infraconstitucionais. Foram criados também o Juizado Especial de Pequenas Causas e a Justiça de Paz Remunerada e o Conselho da Justiça Federal tomou o lugar do antigo Conselho Nacional da Magistratura. Por sua vez, o antigo Tribunal Federal de Recursos foi substituído pelos Tribunais Regionais Federais. À Corte Suprema foi conferida competência para julgar mandados de injunção, ações diretas de inconstitucionalidade e ação declaratórias de constitucionalidade.

De outro lado, foram assegurados os instrumentos processuais (individuais e coletivos) necessários à defesa dos direitos individuais e sociais, além de ser ampliado o rol dos legitimados ativos à propositura de ações visando discutir a constitucionalidade das leis.

Por fim, papel de destaque foi conferido ao Ministério Público, órgão público com a atribuição constitucional de defender a ordem jurídica, o regime democrático e os interesses sociais e individuais indisponíveis.

Afirmamos que o Judiciário assumiu a feição real de Poder a partir da Constituição de 1988, pois apenas neste momento reuniu, concomitantemente, as seguintes características:

a) Atribuição típica de dizer qual a lei aplicável ao caso concreto, ou seja, é um poder que realiza o serviço público de julgar. Como bem adverte Cândido Dinamarco,

\begin{abstract}
na busca do bem comum, o Estado sente a necessidade de remover obstáculos e implantar condições favoráveis à desejada realização integral do homem. Daí os serviços que presta à população e que tradicionalmente costumam ser agrupados nas três clássicas funções consideradas. Essa é, conforme prometido, uma visão marcadamente teleológica, que propõe identificar a jurisdição segundo os objetivos que através dela o Estado busca atingir ${ }^{149}$.
\end{abstract}

b) Competência para se auto-organizar e autonomia financeira.

c) Participação no jogo político, em igualdade de condições com os demais Poderes, respeitando, por óbvio, as competências de cada um. ${ }^{150}$

${ }^{149}$ DINAMARCO, Cândido Rangel. A instrumentalidade do processo. 13. ed. rev. e atual. São Paulo: Malheiros Editores, 2008. p. 136-137.

${ }^{150}$ De acordo com Rogério Arantes, "a condição de poder político do Judiciário nos tempos modernos decorre de sua capacidade de controlar os atos normativos dos demais poderes, especialmente as leis produzidas pelo parlamento. Essa função, conhecida como judicial review ou controle de constitucionalidade das leis, coloca o Judiciário em pé de igualdade com os demais poderes, exatamente naquela dimensão mais importante do sistema político: o processo decisório de estabelecimento de normas (leis e atos executivos) capazes de impor comportamentos. Nos países em que o Judiciário ou um tribunal especial pode ser acionado 
De acordo com Maria Tereza Sadek,

\begin{abstract}
a Constituição de 1988 estabeleceu um modelo de democracia presidencialista e consociativo. O Judiciário foi configurado como um poder de Estado. Em termos institucionais, a Constituição projetou uma arquitetura na qual o Judiciário assumiu um papel de primeiríssima grandeza. Trata-se de uma instituição com dupla face: política e de prestação de serviço. O componente mais explicitamente político se manifesta em sua atribuição de exercer o controle da constitucionalidade de leis e atos normativos de autoria dos demais poderes. $\mathrm{O}$ lado de agência pública encarregada de oferecer serviços volta-se para a garantia de direitos, para a solução de conflitos, para o impedimento e sanções a violações aos direitos humanos. ${ }^{151}$
\end{abstract}

\title{
2.2. O Judiciário como ator político
}

Como um dos três Poderes da República e responsável pela guarda dos direitos consagrados na Constituição Federal, o Judiciário é, necessariamente, um ator político na medida em que participa do jogo político e influi, de forma direta ou indireta, na tomada das decisões políticas relevantes para o país.

O Judiciário é um dos locais utilizados pelos grupos de interesse para contestar as políticas públicas (venue-seeking), ao lado das agências reguladoras e das burocracias específicas. Segundo Matthew Taylor, “o conceito de 'venue seeking' sugere que os atores políticos procuram as instâncias institucionais que mais lhe convêm", a depender da matéria em discussão e do equilíbrio de forças existentes naquele momento específico. Em seu estudo, o Autor demonstra o quanto o Judiciário tem sido instado a participar das discussões importantes para o País, verbis:

\footnotetext{
Em termos comparados, a atuação do Judiciário brasileiro é significativa. Nos 15 anos entre 1988 e 2002, o STF - somente através do instrumento da Ação Direta de Inconstitucionalidade - Adin - concedeu decisões liminares ou de mérito invalidando parcialmente mais de 200 leis federais. Em comparação, entre 1994 e 2002, a Suprema Corte mexicana julgou a constitucionalidade de um pouco mais de 600 leis naquele país usando dois instrumentos parecidos com a Adin,
}

para verificar o respeito das leis e dos atos normativos à Constituição, pode-se dizer que existe um terceiro poder político de Estado, ao lado do Executivo e do Legislativo. Nos países em que essa função inexiste, o Judiciário assemelha-se a um órgão público ordinário, responsável pela importante tarefa de prestar justiça nos conflitos particulares, mas incapaz de desempenhar papel político no processo decisório normativo. É nesse sentido que Estados Unidos e França constituem exemplos paradigmáticos de delegação e de não delegação, respectivamente, desse papel político à magistratura" (Judiciário: entre a Justiça e a Política. In AVELAR, Lúcia; CINTRA, Antônio Octávio. Sistema Político Brasileiro: uma introdução. 2. ed. rev. e ampl. Rio de Janeiro: Konrad-Adenauer-Stiftung; São Paulo: Editora Unesp, 2007. p. 84).

${ }^{151}$ SADEK, Maria Tereza Aina. Poder Judiciário e Democracia: Uma visita a "O Poder Judiciário no Regime Democrático". BUCCI, Maria Paula Dallari. Controle Judicial de Políticas Públicas: Possibilidades e Limites. In BENEVIDES, Maria Victoria de Mesquita; BERCOVICI, Gilberto; MELO, Claudineu de. Direitos Humanos, Democracia e República - Homenagem a Fábio Konder Comparato. São Paulo: Quartier Latin, 2009. p. 715. 
mas invalidou somente 21 leis federais; em toda sua história, a Suprema Corte americana invalidou em torno de 135 leis federais apenas. Mesmo no governo de Fernando Henrique Cardoso - um presidente apoiado (pelo menos inicialmente) por uma ampla coalizão reformista -, o Judiciário federal como um todo foi convocado por atores externos para julgar todas as principais políticas públicas adotadas pelo Executivo e seus aliados no Congresso. O governo Fernando Henrique barganhou duramente para produzir maiorias legislativas que $\mathrm{o}$ permitissem superar as rígidas regras para a aprovação de emendas constitucionais ou leis complementares no Senado e na Câmara. Mas ao final desse imenso esforço político, a contestação judicial da reforma foi um acontecimento crônico, usado recorrentemente por grupos deixados de fora das negociações entre membros do parliamentary agenda cartel. As mais significativas e reais ameaças às reformas surgiram no Judiciário e não no Legislativo: das $1^{\mathrm{a}} \mathrm{s}$ principais iniciativas políticas aprovadas durante o governo Fernando Henrique, todas foram contestadas de alguma forma pelo Judiciário, e sete das 10 foram alteradas ou atrasadas de alguma maneira no STF. Em outras palavras, nem toda proposta do governo foi contestada judicialmente, mas as mais importantes e contenciosas certamente o foram, e com algum sucesso. ${ }^{152} /{ }^{153}$

A abordagem do Poder Judiciário como ator político é feita com a devida profundidade pela Ciência Política, mas não pode ser desconsiderada pelos operadores do Direito na análise do controle judicial das políticas públicas.

Em relação ao momento, é certo dizer que o Judiciário interfere tanto na fase de elaboração quanto na fase de implementação de políticas públicas. Ao sinalizar suas opiniões no curso do processo legislativo, de maneira informal (por meio de entrevistas, reuniões com o Chefe do Executivo e com parlamentares) ou de maneira formal (quando instado a se pronunciar em ação judicial proposta para obstar o andamento do projeto legislativo), o Judiciário influi significativamente no rumo da política, tornando atraentes algumas opções e eliminando outras. Na fase de implementação das políticas, a atuação do Judiciário é bem mais visível. Dependendo do tipo de instrumento utilizado pelos grupos de interesse, a decisão judicial pode ter efeitos abrangentes e retroativos. Ademais, os juízes detêm o controle do timing, podendo retardar ou acelerar políticas quando proferem a decisão de pronto ou quando demoram a decidir.

152 TAYLOR, Matthew. O judiciário e as políticas públicas no Brasil. DADOS - Revista de Ciências Sociais, 2007, v. 50, n. 2, p. 234, 236-237.

${ }^{153}$ Neste sentido, ainda, observam Arantes e Kerche (Judiciário e Democracia no Brasil. Novos Estudos, $n^{\mathbf{0}}$ 54, julho de 1999, p. 39) que "nos últimos dez anos, praticamente todas as intervenções econômicas de maior impacto do governo provocaram ações na Justiça. O hibridismo de nosso sistema, entretanto, acarretou decisões judiciais demoradas e muitas vezes contraditórias. Questões como novos impostos, bloqueio de recursos em contas bancárias, mensalidades escolares, reajustes salariais, privatização das empresas estatais, entre outras tantas, ensejaram longas batalhas judiciais, fundadas em interpretações conflitantes da Constituição. De um lado, isso foi tomado como indicador do grau de liberalização do novo regime; de outro, o modus operandi do controle constitucional implicou custos para a governabilidade, notadamente a insegurança jurídica decorrente da descentralização das decisões judiciais e da falta de vinculação entre elas. Para se ter uma ideia, dos processos relativos a recursos extraordinários e agravos de instrumento entre 1991 e 1996, no STF, nada menos do que $84 \%$ foram repetições de casos já julgados pelo tribunal, ou seja, não teriam percorrido toda a estrutura judiciária até o Supremo se suas decisões tivessem efeito vinculante”. 
Já no que diz respeito à utilização do Judiciário pelos demais atores políticos, especial atenção deve ser dada às regras institucionais.

A depender das normas vigentes, é possível que minorias (derrotadas na fase de deliberação ou mesmo sem qualquer possibilidade de intervenção nesta fase) possam ingressar com ações judiciais visando discutir políticas públicas já formuladas. Vale dizer, o Judiciário transforma-se em nova arena de discussão, ampliando o espaço democrático. Muitas vezes, o Judiciário é acionado mesmo que o possível resultado da ação já seja conhecido de antemão, servindo apenas para demonstrar o descontentamento do Autor da demanda com a política adotada e protelar a sua implementação, atraindo os holofotes da opinião pública. ${ }^{154}$

Apresentaremos a seguir uma situação ocorrida não faz muito e que demonstra, com bastante nitidez, o jogo político entre os Poderes.

Trata-se da evolução legislativa dispondo sobre a cobrança de contribuição social incidente sobre os proventos recebidos pelos servidores públicos inativos e pensionistas.

O texto originário da Constituição de 1988 não continha qualquer previsão de incidência desta contribuição social. Foi alterado pela Emenda Constitucional no 03/1993, sendo introduzido o $\S 6^{\circ}$ ao artigo 40 , com o seguinte teor:

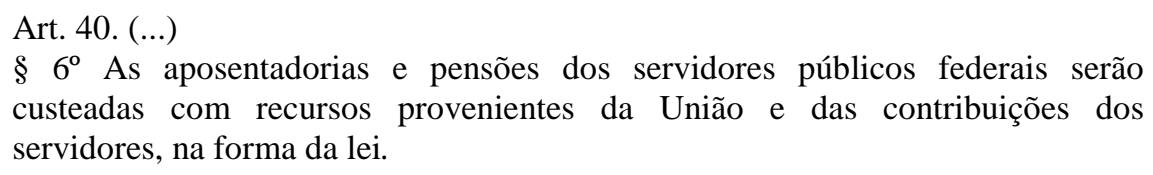

Neste contexto, foi editada a Medida Provisória n ${ }^{\circ}$ 1.415, de 29 de abril de 1996, que, dando nova redação ao artigo 231 da Lei $n^{\circ}$ 8.112/1990, instituiu a contribuição dos servidores inativos, verbis:

Art. 231. O plano de Seguridade Social do servidor será custeado com o produto da arrecadação de contribuições sociais obrigatórias dos servidores ativos e inativos dos três Poderes da União, das autarquias e das fundações públicas.

A Medida Provisória n 1.415 foi atingida pela caducidade, não sendo convertida em lei.

A Emenda Constitucional n ${ }^{\circ} 20 / 1998$, por sua vez, alterou radicalmente a redação do $\S 6^{\circ}$ do artigo 40, nada mais mencionando acerca da cobrança de contribuição previdenciária por parte dos servidores inativos.

${ }^{154}$ TAYLOR, Matthew. Revista, cit., p. 246. 
Foi publicada, no ano de 1999, a Lei $\mathrm{n}^{\circ}$ 9.873, estabelecendo a contribuição dos inativos no setor público.

Dispunha em seu artigo $1^{\circ}$ que:

Art. $1^{\circ}$ A contribuição social do servidor público civil, ativo e inativo, e dos pensionistas dos três Poderes da União, para a manutenção do regime de previdência social dos seus servidores, será de onze por cento, incidente sobre a totalidade da remuneração de contribuição, de provento ou da pensão.(...).

O dispositivo foi declarado inconstitucional pelo Supremo Tribunal Federal, no julgamento da Ação Direta de Inconstitucionalidade nº 2.010-2/DF, Relator Ministro Celso de Mello, ao fundamento de que a exação não poderia ser disciplinada por lei ordinária.

De acordo com Marcus André Melo:

\begin{abstract}
Uma batalha legal desenvolveu-se no Judiciário através de 1050 ações individuais e 16 ações civis públicas. O PT, a OAB e a Confederação Nacional de Servidores Públicos também impetraram ADINS contra a medida. Agindo como um veto player, o Judiciário declarou a medida inconstitucional. A disputa legal paralisou a implementação da lei e causou perdas de receita de curto prazo estimadas de até $\mathrm{R} \$ 267$ milhões e produzindo perdas totais calculadas em $\mathrm{R} \$$ 7,6 bi em 1999 e $2000 .^{155}$
\end{abstract}

Atendendo então às diretrizes estabelecidas pela Corte Suprema, o Poder Executivo elaborou um projeto de emenda constitucional, aprovado de acordo com as regras constitucionais e que culminou com a instituição válida da exação no ordenamento, por força da Emenda Constitucional nº 41/2003.

Instado finalmente a se manifestar sobre a constitucionalidade da contribuição instituída pela Emenda, o Supremo Tribunal Federal não vislumbrou qualquer vício formal a contaminá-la.

Este breve retrospecto nos mostra como as políticas públicas sofrem influência indireta do Poder Judiciário no seu processo de elaboração.

Destaca-se que em momento algum o Poder Judiciário interferiu na esfera de atribuições típicas do Poder Legislativo. Quando acionado, ateve-se inicialmente à análise do instrumento legal utilizado pelo legislador infraconstitucional para disciplinar a matéria. Ao julgar a ADIN 2010-2/DF, considerou a inadequação da lei ordinária para tratar do assunto, sequer adentrando na análise do mérito, dada a inconstitucionalidade formal do

155 MELO, Marcus André. Reformas Constitucionais no Brasil - Instituições Políticas e Processo Decisório. Rio de Janeiro: Editora Revan, 2002. p. 132. 
ato normativo. Apenas quando considerou adequado o meio utilizado - emenda constitucional - é que passou a se pronunciar sobre o mérito.

\title{
2.3. A legitimidade do Poder Judiciário e a questão democrática
}

É argumento comum afirmar que falta legitimidade ao Judiciário para invalidar atos praticados pelos Poderes Legislativo e Executivo (limitados, neste trabalho, às políticas públicas), cujos representantes foram devidamente eleitos pelo povo e atuam de acordo com a vontade deste. Em suma, o Judiciário é um Poder antidemocrático, vez que composto por pessoas não 'escolhidas' pela sociedade e, portanto, sem condições de representá-la.

A discussão está centrada, fundamentalmente, na seguinte questão: é possível substituir a discricionariedade do legislador e do administrador pela discricionariedade do juiz?

\begin{abstract}
A discricionariedade legislativa decorre da inexistência de parâmetros normativos ou de sua flexibilidade; a administrativa está relacionada, igualmente, à abertura textual, mas, também, ao deferimento explícito de mais de uma possibilidade de conduta diante da espécie fática; por último, a discricionariedade judicial cobre, de um modo muito mais amplo do que em sede legislativa ou administrativa, todo o campo da criatividade na interpretação. Há, portanto, apenas no que tange à jurisdição, uma relação íntima entre discricionariedade e interpretação, podendo-se dizer que aquela é parte integrante desta. A categoria teórica da discricionariedade, em qualquer uma de suas vertentes, está fortemente vinculada ao princípio da separação dos Poderes. Importa na contenção do controle jurisdicional em favor do Poder Legislativo ou da Administração, diante da inexistência de limitação normativa ou em face do entendimento de que as normas existentes não autorizam ao Poder Judiciário a imposição de determinado padrão de conduta em substituição àquele adotado pelo Poder controlado. Esse entendimento, por si, já decorre de um determinado modo de compreender o ordenamento jurídico, a partir da ideia de adequação orgânico-funcional, em consonância com o princípio da separação. A discricionariedade judicial também floresce no espaço que os balizamentos normativos autorizam o julgador a se movimentar, porém com a sensível diferença de que o controle, nesse caso, compete ao próprio órgão ao qual foi conferido o poder discricionário, o que não significa que possa, em harmonia com o sistema, tudo fazer. (...). ${ }^{156}$
\end{abstract}

Para responder a questão, devemos partir do pressuposto de que o Brasil adotou expressamente o modelo de revisão judicial, conferindo ao Judiciário competência para verificar, caso a caso, se houve ou não violação de direito.

${ }^{156}$ RAMOS, Elival da Silva. Parâmetros Dogmáticos do Ativismo Judicial em Matéria Constitucional. Tese apresentada à Faculdade de Direito da Universidade de São Paulo para inscrição em concurso público visando ao provimento de cargo de professor titular, junto do Departamento de Direito do Estado - área de Direito Constitucional. São Paulo, 2009. 
As atribuições dos juízes constam expressamente da Constituição e foram conferidas pelos próprios cidadãos quando da elaboração da carta constitucional, ocorrendo a participação democrática na escolha deste modelo de justiça. ${ }^{157}$

Ademais, é justamente a imparcialidade dos juízes que lhes garante o correto exercício de suas funções, vez que não são obrigados a defender tal ou qual interesse, mas apenas e tão somente resguardar os direitos fundamentais inscritos na Constituição. Confira-se:

\begin{abstract}
O supremo tribunal harmoniza-se com essa ideia de democracia constitucional dualista, como um dos dispositivos institucionais para proteger a lei mais alta. Ao aplicar a razão pública, o tribunal deve evitar que a lei seja corroída pela legislação de maiorias transitórias, ou mais provavelmente, por interesses estritos, organizados e bem posicionados, muito hábeis na obtenção do que querem. ${ }^{158}$
\end{abstract}

Samuel Freeman, na esteira de Rawls, afirma que a revisão judicial "não é uma limitação à soberania igual e sim ao poder legislativo ordinário, em benefício da proteção dos direitos iguais de soberania democrática. Entendida dessa forma, a revisão judicial é um tipo de comprometimento prévio comum de cidadãos soberanos livres e iguais no nível da escolha constitucional". 159

Ronald Dworkin também defende o modelo de revisão judicial, com a expressa ressalva de que as decisões judiciais devem se amparar em princípios e não em políticas, vale dizer, têm como objeto os direitos que as pessoas possuem sob o sistema constitucional, não adentrando na discussão acerca dos meios de promoção do bem-estar geral, questão da alçada dos Poderes Legislativo e Executivo. Ao Judiciário não cabe, portanto, qualquer intervenção direta na elaboração da política. ${ }^{160}$

\footnotetext{
${ }^{157}$ Dois foram os principais modelos de justiça nos séculos XIX e XX e que exerceram grande influência sobre os demais Estados: a) o modelo norte-americano e b) o modelo francês. De acordo com Rogério Arantes, "a experiência francesa, mais republicana do que liberal, modernizou a função de justiça comum do Judiciário mas não lhe conferiu poder político; a americana, mais liberal do que republicana, não só atribuiu à magistratura a importante função de prestação de justiça nos conflitos entre particulares, como elevou o Judiciário à condição de poder político" (ARANTES, Rogério Bastos. Judiciário: entre a Justiça e a Política. In AVELAR, Lúcia; CINTRA, Antônio Octávio. Op. cit., p. 82).

${ }^{158}$ RAWLS, John. O liberalismo político. Lisboa: Editorial Presença, 1997. p. 282.

${ }^{159}$ FREEMAN, Samuel. Democracia e Controle Jurídico da Constitucionalidade. Lua Nova, 1994, volume 32, p. 190.

${ }^{160}$ Conforme o Autor, “a democracia supõe igualdade de poder político e se decisões políticas genuínas são tiradas do legislativo e entregues aos tribunais, então o poder político dos cidadãos individuais, que elegem legisladores mas não juízes, é enfraquecido, o que é injusto. Não se trata de um juízo metafísico de justiça, mas sim da percepção de que a atividade política dos juízes acaba por gerar um comprometimento democrático relevante, ao ponto em que se todo o poder político fosse transferido para os juízes, a democracia e a igualdade do poder político seriam destruídas" (DWORKIN, Ronald. Uma questão de princípio. 2. ed. São Paulo: Martins Fontes, 2005. p. 101).
} 
Ao debruçar-se sobre eventual violação a direito fundamental perpetrada por determinada política pública, não cabe aos juízes definir quais objetivos serão perseguidos, mas sim verificar se as opções feitas pelo Legislativo e pelo Executivo são compatíveis com os direitos fundamentais assegurados no texto constitucional.

Em suma, os juízes são responsáveis pela preservação dos direitos fundamentais e manutenção da democracia, nos moldes acima delineados, qual seja, respeitando as escolhas feitas pelos Poderes competentes, sem qualquer iniciativa na fase de elaboração propriamente dita das políticas públicas.

Não obstante a clara opção do Estado brasileiro, merecem ser destacados os argumentos defendidos pelos opositores do modelo do judicial review.

O Professor Jeremy Waldron exalta a importância do Poder Legislativo e do sistema majoritário, em detrimento da revisão judicial. Afirma que sob a ótica de órgão colegiado, não há diferenças entre o Parlamento e o Judiciário no método decisório, pois ambos adotam o princípio majoritário. A diferença está na representação, donde se extrai que o Legislativo tem muito mais legitimidade do que os Tribunais, eis que seus membros são eleitos pelos cidadãos e têm o dever de defender suas aspirações. ${ }^{161}$ A noção de que ao Judiciário cabe a defesa dos direitos fundamentais inscritos na Carta Magna é falaciosa, na medida em que as decisões das Cortes Judiciais representam a maioria dos votos dos seus membros e qualquer que seja o resultado - justo ou injusto, legal ou ilegal, fundamentado ou não - ele prevalecerá. Assim, não há qualquer garantia de que a decisão judicial final assegure, efetivamente, os direitos fundamentais. ${ }^{162}$

De acordo com esta visão, a revisão judicial não sofre qualquer limitação e aí está o perigo. A decisão não é legitimada por seu conteúdo, pois se assim fosse qualquer um com que ele não concordasse, estaria livre para não cumpri-la. Em suma: em sendo válido o princípio majoritário, que prevaleça a instância com maior legitimidade (Poder Legislativo).

A rigor, tanto a atuação administrativa como a atuação judicial devem obedecer a parâmetros previamente estabelecidos. Não se mostra suficiente à solução dos problemas

\footnotetext{
${ }^{161}$ Para maiores detalhes, conferir a obra do A Dignidade da Legislação, publicada pela Martins Fontes (São Paulo) em 2003.

162 “A Suprema Corte não seria, para Waldron, uma instituição contramajoritária. Ao contrário, toma todas as suas decisões por maioria, ou seja, com base numa maioria simples. Além disso, apesar de os juízes apoiarem suas decisões em longos arrazoados, a qualidade da decisão não tem impacto nenhum no peso do seu voto. Não vale mais por ter feito uma pesquisa erudita, por ter um argumento coerente; será somente mais um voto a somar-se aos outros. O voto mais eloquente conta a mesma coisa que um medíocre para a decisão final" (MENDES, Conrado Hübner. Controle de constitucionalidade e democracia. Rio de Janeiro: Elsevier, 2008. p. 102).
} 
apenas reconhecer a maior discricionariedade de um (Legislativo e Executivo) em detrimento de outro (Judiciário), mas estabelecer as fronteiras de atuação de cada um.

A doutrina brasileira, como bem ressaltado pela Professora Maria Paula Dallari Bucci $^{163}$, muito tem se debruçado sobre a questão do controle judicial das políticas públicas e pouco tem se dedicado ao seu processo de formulação e execução, concentrando todos os esforços nos postulados constitucionais e na atuação dos juízes, como se o Judiciário fosse a única instância de solução existente para a concretização dos direitos fundamentais.

A atuação judicial é eminentemente retrospectiva, ao passo que a atuação dos Poderes Executivo e Legislativo na formulação de políticas públicas é essencialmente prospectiva, na medida em que envolve um contingente definido de beneficiários, as verbas necessárias à consecução do programa, a participação de vários órgãos públicos envolvidos na realização da política, entre outros.

Esta constatação é fundamental para compreender os limites do controle judicial das políticas públicas e alterar o foco das discussões, de forma que cada Poder, no âmbito de suas atribuições, seja instado a atuar de modo que maximize a concretização dos direitos fundamentais. Não basta, portanto, ingressar com ações judiciais visando afastar ou modificar as políticas públicas já editadas, mas valer-se das vias democráticas para exigir que sejam editadas políticas públicas de melhor qualidade.

\subsection{Ativismo judicial}

Correlata à legitimidade do controle judicial e que pouco a pouco vem sendo desbravada pela doutrina é a discussão acerca do ativismo judicial.

O ativismo traduz, em poucas palavras: $(i)$ uma nova disposição dos juízes em discutir questões antes reservadas, exclusivamente, ao Legislativo e ao Executivo, (ii) a adoção dos procedimentos judiciais e parâmetros jurisprudenciais no âmbito dos demais Poderes e (iii) a influência dos valores e preferências políticas dos juízes como condição e efeito da expansão do poder das Cortes. ${ }^{164}$

\footnotetext{
${ }^{163}$ No artigo "Controle Judicial de Políticas Públicas: Possibilidades e Limites". IN: BENEVIDES, Maria Victoria de Mesquita; BERCOVICI, Gilberto; MELO, Claudineu de. Op. cit., p. 693-711.

${ }^{164}$ No mesmo sentido, afirma Fábio Kerche que "a judicialização da política é um fenômeno, segundo Marcus Faro de Castro, baseado em dois pontos: o primeiro é 'um novo 'ativismo judicial', isto é, uma nova disposição de tribunais judiciais no sentido de expandir o escopo das questões sobre as quais eles devem formar juízos jurisprudenciais (muitas dessas questões até recentemente ficavam reservadas ao tratamento dado pelo Legislativo ou pelo Executivo) (...). O segundo fenômeno é gerado pelo 'interesse de políticos e
} 
De acordo com Tate e Vallinder, autores americanos que sistematizaram a discussão na obra The Global Expansion of Judicial Power, o ativismo judicial está estritamente relacionado ao fenômeno da judicialização da política e da politização do Judiciário, expressões que indicam os efeitos da expansão do Poder Judiciário no processo decisório das democracias contemporâneas. ${ }^{165}$

Algumas condições favorecem a judicialização da política, como: (i) a existência de um regime de governo democrático; (ii) a existência de uma 'política de direitos' traduzida em uma carta de direitos ou em uma declaração constitucional de direitos fundamentais; (iii) a existência de grupos de pressão que tenham identificado os tribunais como possíveis arenas para a discussão de seus interesses; (iv) o uso eventual das cortes como instrumento político utilizado pela oposição para impedir a edição de leis que ela, pelas vias normais, não conseguiria; (v) a existência de 'instituições majoritárias inefetivas', ou seja, incapazes de reunir em torno de si apoio político suficiente para defender suas políticas diante de possíveis ataques originados no Poder Judiciário; (vi) uma percepção geral negativa sobre as instituições originariamente responsáveis pela formulação de políticas públicas; (vii) inércia proposital quanto ao trato de certas questões particularmente delicadas por parte das instituições majoritárias. ${ }^{166}$

Rogério Arantes vislumbra a presença de tais condições no caso brasileiro, nos seguintes termos:

a democracia restabelecida nos anos 80, seguida de uma Constituição pródiga em direitos em 1988, com um número cada vez maior de grupos de interesses organizados demandando solução de conflitos coletivos, contrastando com um sistema político pouco majoritário, de coalizões e partidos frágeis para sustentar o governo, enquanto os de oposição utilizam o Judiciário para contê-lo, além de um modelo constitucional que delegou à Justiça a proteção de interesses em diversas áreas, refletindo até mesmo o alto grau de legitimidade do Judiciário e do Ministério Público como instituições capazes de receber tal delegação. ${ }^{167}$

O ativismo está relacionado ao poder judicial de criar o direito, não no sentido de fazer as vezes do legislador, mas sim no de buscar a realização da justiça no caso concreto,

autoridades administrativas em adotar (a) procedimentos semelhantes aos processos judiciais e (b) parâmetros jurisprudenciais em suas deliberações (muitas vezes, o Judiciário é politicamente provocado a fornecer esses parâmetros'.' Segundo o autor, a judicialização da política - não exclusiva do Estado brasileiro - é consequência da ampliação da proteção dos direitos após a II Guerra Mundial e a diminuição da eficácia de políticas macroeconômicas no final dos anos 60" (O Ministério Público e a Constituinte de 1987/88. In SADEK, Maria Tereza (org.). O sistema de justiça. São Paulo: IDESP/Sumaré, 1999. p. 62).

165 TATE, C. Neal; VALLINDER, Torbjörn. The Global Expansion of Judicial Power. Nova York: New York University Press, 1995.

${ }^{166}$ Idem, ibidem.

167 ARANTES, Rogério Bastos. Judiciário: entre a Justiça e a Política. In: AVELAR, Lúcia; CINTRA, Antônio Octávio. Op. cit., p. 107-108. 
mediante aplicação das normas já existentes. A função meramente interpretativa cede espaço ao trabalho criativo, sem incorrer no âmbito da arbitrariedade, pois os limites postos pelo ordenamento não podem ser desbordados.

O poder de criação do juiz foi objeto de análise por Mauro Cappelletti, um dos estudiosos pioneiros na matéria, que assim sintetiza o fenômeno do ativismo:

\begin{abstract}
É manifesto o caráter acentuadamente criativo da atividade judiciária de interpretação e de atuação da legislação e dos direitos sociais. Deve-se reiterar, é certo, que a diferença em relação ao papel mais tradicional dos juízes é apenas de grau e não de conteúdo: mais uma vez impõe-se repetir que, em alguma medida, toda interpretação é criativa, e que sempre se mostra inevitável um mínimo de discricionariedade na atividade jurisdicional. Mas, obviamente, nessas novas áreas abertas à atividade dos juízes haverá, em regra, espaço para mais elevado grau de discricionariedade e, assim, de criatividade, pela simples razão de que quanto mais vaga a lei e mais imprecisos os elementos do direito, mais amplo se torna também o espaço deixado à discricionariedade nas decisões judiciárias. Esta é, portanto, poderosa causa da acentuação que, em nossa época, teve o ativismo, o dinamismo e, enfim, a criatividade dos juízes. ${ }^{168}$
\end{abstract}

No polo oposto, o ativismo judicial é definido como

o exercício da função jurisdicional para além dos limites impostos pelo próprio ordenamento que incumbe, institucionalmente, ao Poder Judiciário fazer atuar, resolvendo litígios de feições subjetivas (conflitos de interesse) e controvérsias de natureza objetiva (conflitos normativos). Há, como visto, uma sinalização claramente negativa no tocante às práticas ativistas, por importarem na desnaturação da atividade típica do Poder Judiciário, em detrimento dos demais Poderes. Não se pode deixar de registrar mais uma vez, contudo, que o fenômeno golpeia mais fortemente o Poder Legislativo, o qual tanto pode ter o produto da legiferação irregularmente invalidado por decisão ativista (em sede de controle de constitucionalidade), quanto o seu espaço de conformação normativa invadido por decisões excessivamente criativas. ${ }^{169}$

Como mencionado no início deste tópico, a discussão acerca do ativismo vem, aos poucos, sendo enfrentada pelos doutrinadores, mostrando-se prematura, nesta fase e no presente trabalho, qualquer conclusão definitiva.

Adotamos, por ora, a corrente doutrinária que reconhece a possibilidade da função criativa do juiz, desde que exercida no seu espaço de atuação, constitucionalmente traçado. O ativismo é um forte aliado do juiz na análise das políticas públicas, pois seu caráter interdisciplinar não comporta o exame meramente pontual das questões envolvidas. $\mathrm{O}$ controle das políticas públicas exige um olhar multifacetado da realidade e, embora o juiz

${ }^{168}$ CAPPELLETTI, Mauro. Juízes legisladores? Porto Alegre: Sérgio Antonio Fabris Editor, 1993/reimpr., 1999. p. 42.

${ }^{169}$ RAMOS, Elival da Silva. Tese, cit., p. 99-100. 
se pronuncie apenas sob o aspecto jurídico, considera, para tanto, os variados fatores externos relacionados.

Em suma, mesmo reconhecendo que o Direito cuida apenas de um vértice do problema, neste espaço de atuação (legitimamente reconhecido) a atividade do juiz é plena, sendo ampla a margem de interpretação.

Não estamos sugerindo que nossa Constituição democrática seja concretizada de forma elitizada, pelas mãos tão somente dos operadores do Direito, mas sim que o Poder Judiciário contribua, tanto quanto possível, para a sua efetivação. ${ }^{170}$

\subsection{Controle judicial de políticas públicas}

Feitas tais ressalvas, chegamos, finalmente, a uma das questões mais tortuosas em matéria de políticas públicas: o controle judicial.

Neste ponto do estudo, parece não existir mais dúvida acerca da legitimidade do Judiciário na questão. Em termos simplistas, buscando introduzir a intervenção judicial nas políticas públicas: sempre que uma política pública acobertar eventual lesão ou ameaça de lesão, o Judiciário pode ser instado a se pronunciar, quer através de ação individual, quer através de ação coletiva.

\subsubsection{Aspectos gerais do controle de constitucionalidade no direito brasileiro}

O controle de constitucionalidade, embora atribuição típica do Poder Judiciário, também é exercido pelos Poderes Executivo e Legislativo, o denominado controle político.

No Brasil foi clara a opção do legislador constituinte em outorgar ao Judiciário o poder-dever de dizer o Direito, função que em alguns países é exercida por outros órgãos. ${ }^{171}$

\footnotetext{
${ }^{170}$ O Professor Elival da Silva Ramos, ao concluir sua tese, manifestou esta preocupação: "Não devemos incidir no equívoco elitista de tentar concretizar uma Constituição democrática paradoxalmente, atribuindo ao povo um papel secundário. $\mathrm{O}$ ativismo judicial, que seduz os incautos e agrupa os aristocratas do direito, existe tanto na jurisprudência 'progressista' a proclamar a aplicabilidade imediata de direitos sociais veiculados por normas programáticas, quanto na resistência abusiva da Suprema Corte estadunidense à legislação trabalhista, no período do 'governo dos juízes'. Compete aos juristas democratas colocar o seu saber a serviço da construção de instituições que permitam o triunfo de um governo que se faça não apenas em benefício do povo, mas com a sua participação decisiva, diretamente, sob determinadas condições, e indiretamente, de modo diuturno, por meio dos instrumentos de representação política" (Tese, cit., p. 273).

${ }^{171}$ Cite-se, como exemplo, a França, que possui um Conselho Constitucional (Conseil Constitutionnel), de natureza eminentemente política, formado pelos ex-Presidentes da República e mais 9 (nove) membros, dos
} 
Adotou-se, aqui, o sistema misto possibilitando que todo e qualquer juiz, quando acionado, pode se pronunciar - via incidental - sobre a inconstitucionalidade de qualquer ato normativo (controle difuso), admitindo-se, outrossim, que o controle seja feito pelo Supremo Tribunal Federal, via ação direta de inconstitucionalidade, ação declaratória de constitucionalidade e ação de inconstitucionalidade por omissão (controle concentrado).

No caso do controle difuso, a discussão pode ser levada à apreciação do Supremo Tribunal Federal por meio de Recurso Extraordinário. A declaração de inconstitucionalidade terá efeitos inter partes. Pode, no entanto, produzir efeitos erga omnes, desde que o Senado Federal seja comunicado da decisão proferida pelo Supremo Tribunal Federal e suspenda a execução, no todo ou em parte, da lei declarada inconstitucional, por meio de resolução (CF, artigo 52, X), a partir da qual a decisão será estendida a todos.

Quando se trata de controle concentrado, os efeitos da decisão da Corte Maior são: (i) ex tunc, ou seja, retroativos à data da edição da norma declarada inconstitucional; (ii) erga omnes; (iii) vinculantes em relação aos demais órgãos do Poder Judiciário e à administração pública direta e indireta, nas esferas federal, estadual e municipal. ${ }^{172}$

\subsubsection{Objeto}

As políticas públicas são formadas por um conjunto de atos, editados com a finalidade específica de efetivar um direito social.

Desta forma, defende a melhor doutrina que o controle judicial de constitucionalidade deve ter por objeto todos os atos normativos que compõem a política, não sendo possível a análise isolada e pontual de cada um deles, sob pena de desvirtuamento do programa planejado e não cumprimento do objetivo proposto. Neste sentido, as advertências de Fábio Konder Comparato:

quais 3 (três) são nomeados pelo Presidente da República, 3 (três) pelo Presidente da Assembleia Nacional e 3 (três) pelo Presidente do Senado.

${ }^{172}$ É possível, em circunstâncias específicas, a modulação de tais efeitos, no que diz respeito ao aspecto temporal. Nos termos do artigo 27 da Lei $n^{\circ}$ 9.868/99, “Ao declarar a inconstitucionalidade de lei ou ato normativo, e tendo em vista razões de segurança jurídica ou de excepcional interesse social, poderá o Supremo Tribunal Federal, por maioria de dois terços de seus membros, restringir os efeitos daquela declaração ou decidir que ela só tenha eficácia a partir de seu trânsito em julgado ou de outro momento que venha a ser fixado". Embora o dispositivo legal esteja incluído na parte relativa ao controle concentrado de constitucionalidade, o Supremo Tribunal Federal já admitiu a sua incidência em caso de controle difuso (Recurso Extraordinário 197.917-8). 
A política, como conjunto de normas e atos, é unificada pela sua finalidade. Os atos, decisões ou normas que a compõem, tomados isoladamente, são de natureza heterogênea e submetem-se a um regime jurídico que lhes é próprio.

De onde se segue que o juízo de validade de uma política - seja ela empresarial ou governamental - não se confunde nunca com o juízo de validade das normas e dos atos que a compõem. Uma lei, editada no quadro de determinada política pública, por exemplo, pode ser inconstitucional, sem que esta última o seja. Inversamente, determinada política governamental, em razão da finalidade por ela perseguida, pode ser julgada incompatível com os objetivos constitucionais que vinculam a ação do Estado, sem que nenhum dos atos administrativos, ou nenhuma das normas que a regem, sejam, em si mesmos, inconstitucionais. ${ }^{173}$

Não obstante a coerência do raciocínio acima exposto, nosso objeto de estudo não permite sua aplicação.

As políticas públicas previdenciárias, aqui consideradas como a política de Estado e as políticas de Governo, não são disciplinadas de forma coerente e organizada, não se encontrando sistematizadas em um conjunto de atos integrados. Muitas vezes, há incompatibilidade entre a lei e o decreto; em outras, a incompatibilidade está entre o decreto e a Constituição; ou, ainda, entre a lei e a Constituição; entre a orientação interna administrativa e a lei; etc. São muitas as hipóteses e muitos os atos normativos, em alguns casos estão todos efetivamente contaminados, em outros não.

Por tais razões, o ponto máximo que conseguimos alcançar é estabelecer os critérios que permitam identificar os pontos controvertidos a serem cotejados pelo juiz (inscritos em normas constitucionais, legais e infralegais) e os parâmetros a serem observados na análise.

A intervenção judicial também é possível em casos de omissão legislativa, oferecendo o ordenamento jurídico os instrumentos legais adequados para a provocação do Judiciário pela via direta (mandado de injunção, ação direta de inconstitucionalidade por omissão, arguição de descumprimento de preceito fundamental) e via difusa (ações individuais e coletivas). Nos tópicos a seguir, veremos quais os limites de atuação judicial nos casos de inércia do Poder competente para a edição e concretização da política, de forma que resolva a lide submetida à sua apreciação e, ao mesmo tempo, não invada a esfera de atribuições dos outros Poderes.

${ }^{173}$ COMPARATO, Fábio Konder. Ensaio sobre o juízo de constitucionalidade de políticas públicas. Revista dos Tribunais, ano 86, volume 737, março de 1997, p. 18-19. 


\subsubsection{Parâmetros do controle judicial}

Ao Poder Judiciário compete verificar, caso a caso, se a política pública é válida e suficiente a dar concretude ao direito fundamental social em questão, manifestando-se quando for o caso - acerca da constitucionalidade das supostas restrições estabelecidas, de forma difusa ou concentrada, a depender do modo como for acionado.

É importante ressaltar que o presente item se volta especialmente a estabelecer parâmetros para o controle judicial de políticas públicas já existentes, podendo ser utilizados, subsidiariamente, nos casos de omissão do Poder competente.

Explico.

O pressuposto da intervenção judicial é a suposta lesão a direito fundamental social, donde se excluem, de antemão, discussões meramente técnicas de políticas públicas, foro reservado à esfera política, como visto no Capítulo 1. Ao Judiciário não assiste competência para formular políticas públicas, ou seja, entre as várias alternativas possíveis escolher a que considerar mais adequada. Ele só é chamado a intervir quando já formulada a política pública pelo órgão competente.

No entanto, há casos em que a violação ao direito fundamental ocorre mediante omissão legislativa, hipótese que autoriza a provocação judicial através do ajuizamento dos seguintes instrumentos processuais: (i) ação direta de inconstitucionalidade por omissão; (ii) mandado de injunção; (iii) ação de descumprimento de preceito fundamental.

Dada a impossibilidade de recusa do Poder Judiciário em dizer o Direito, deve então se debruçar sobre os motivos da inércia do legislador e dar a solução cabível ao caso concreto.

\subsubsection{Princípios e regras}

É necessário então estabelecer os critérios de que se vale o Poder Judiciário para analisar a constitucionalidade e legalidade do ato praticado pelo órgão político.

Tais critérios são fornecidos pelos princípios e pelas regras. De acordo com Robert Alexy,

tanto regras quanto princípios são normas, porque ambos dizem o que deve ser. Ambos podem ser formulados por meio das expressões deônticas básicas do dever, da permissão e da proibição. Princípios são, tanto quanto as regras, razões para juízos concretos de dever-ser, ainda que de espécie muito diferente. A 
distinção entre regras e princípios é, portanto, uma distinção entre duas espécies de normas. ${ }^{174}$

Carmen L. Rocha conceitua os princípios como

os conteúdos intelectivos dos valores superiores adotados em dada sociedade política, materializados e formalizados juridicamente para produzir uma regulação política no Estado. Aqueles valores superiores encarnam-se nos princípios que formam a própria essência do sistema constitucional, dotando-os, assim, para cumprimento de suas funções, de normatividade jurídica. A sua opção eticossocial antecede a sua caracterização normativo-jurídica. Quanto mais coerência guardar a principiologia constitucional com aquela opção, mais legítimo será o sistema jurídico e melhores condições de ter efetividade jurídica e social. ${ }^{175}$

Os princípios têm grau de abstração maior que as regras, o que não significa, absolutamente, que não são dotados de eficácia. É justamente por força da sua generalidade e vagueza que os princípios se amoldam às diferentes situações e acompanham o passo da evolução social. ${ }^{176}$ Por tais razões, podem incidir em situações diversas, não se limitando a casos específicos. Ao contrário das regras - que são "razões definitivas", os princípios são razões prima facie.

Os princípios, por traduzirem os valores superiores adotados pela sociedade, são "os elementos conformadores de uma unidade político-constitucional" 177 e se constituem nas principais ferramentas à disposição do órgão judicial para a resolução dos conflitos. Não fornecem uma única resposta certa e obrigam o julgador a encontrar, caso a caso, a resposta que mais se aproxima dos valores dignidade humana e democracia, postulados fundantes do Estado brasileiro, na forma do artigo $3^{\circ}$ da Constituição Federal.

De acordo com Alexy, os princípios e regras se diferenciam nos seguintes aspectos:

O ponto decisivo na distinção entre regras e princípios é que princípios são normas que ordenam que algo seja realizado na maior medida possível dentro das possibilidades jurídicas e fáticas existentes. Princípios são, por conseguinte, mandamentos de otimização, que são caracterizados por poderem ser satisfeitos em graus variados e pelo fato de que a medida devida de sua satisfação não depende somente das possibilidades fáticas, mas também das possibilidades jurídicas. O âmbito das possibilidades jurídicas é determinado pelos princípios e regras opostos.

Já as regras são normas que são sempre ou satisfeitas ou não satisfeitas. Se uma regra vale, então, deve se fazer exatamente aquilo que ela exige; nem mais, nem menos. Regras contêm, portanto, determinações no âmbito daquilo que é fática e

${ }^{174}$ ALEXY, Robert. Teoria dos Direitos Fundamentais. São Paulo: Malheiros Editores, 2008. p. 87.

175 Carmen Lúcia A. Rocha, apud ROTHENBURG, Walter Claudius. Princípios Constitucionais. 2. tir. Porto Alegre: Sérgio Antonio Fabris, 2003. p. 17.

${ }^{176}$ ROTHENBURG, Walter Claudius. Op. cit., p. 21.

${ }^{177}$ CORREIA, Marcus Orione Gonçalves. Interpretação do Direito da Segurança Social. In ROCHA, Daniel Machado; SAVARIS, José Antonio (coords.). Op. cit., p. 258. 
juridicamente possível. Isso significa que a distinção entre regras e princípios é uma distinção qualitativa, e não uma distinção de grau. Toda norma é ou uma regra ou um princípio. ${ }^{178}$

Princípios e regras divergem, ainda, quando postos em posição de conflito. "Um conflito entre regras somente pode ser solucionado se se introduz, em uma das regras, uma cláusula de exceção que elimine o conflito, ou se pelo menos uma das regras for declarada inválida" ${ }^{179}$

No caso de colisão entre princípios, um deles

terá que ceder. Isso não significa, contudo, nem que o princípio cedente deva ser declarado inválido, nem que nele deverá ser introduzida uma cláusula de exceção. Na verdade, o que ocorre é que um dos princípios tem precedência em face do outro sob determinadas condições. Sob outras condições a questão da precedência pode ser resolvida de forma oposta. Isso é o que se quer dizer quando se afirma que, nos casos concretos, os princípios têm pesos diferentes e que os princípios com maior peso têm precedência. Conflitos entre regras ocorrem na dimensão da validade, enquanto as colisões entre princípios - visto que só princípios válidos podem colidir - ocorrem, para além dessa dimensão, na dimensão do peso. ${ }^{180}$

O conflito entre princípios ${ }^{181}$ é resolvido mediante a técnica do sopesamento ou a máxima da proporcionalidade em sentido estrito. ${ }^{182}$ De acordo com Alexy, deve ser estabelecida uma relação de precedência condicionada entre os princípios concorrentes, relação que indica, no caso concreto, em que condições um princípio prevalece sobre outro, precedência que pode se alterar se outra for a situação apresentada. ${ }^{183}$

As críticas formuladas ao método de ponderação (sopesamento) centram-se na ideia de que ele não se constitui em um modelo racional, na medida em que abre espaço ao subjetivismo e decisionismo dos juízes. O Professor Alexy rebate tais alegações demonstrando que o sopesamento por ele proposto é fundamentado, de forma que "um sopesamento é racional quando o enunciado de preferência, ao qual ele conduz, pode ser

${ }^{178}$ ALEXY, Robert. Op. cit., p. 90-91.
${ }^{179}$ Idem, ibidem, p. 92.
${ }^{180}$ ALEXY, Robert. Op. cit., p. 93-94.

${ }^{181}$ ALEXY, Robert. Op. cit., p. 93-94.
Walter Claudius Rothenburg apresenta a distinção entre conflito e concorrência, nos seguintes termos: “(...) o concurso entre princípios pode ser positivo ou negativo. A primeira situação: há colisão de princípios quando princípios conflitantes são suscitados, devendo-se resolver com base na precedência de um ou vários em detrimento dos demais, que são episodicamente afastados; por exemplo: vida privada versus liberdade de informação. A segunda: existe concorrência de princípios quando princípios convergentes incidem sobre o caso, resolvendo-se por composição; exemplo: os princípios da moralidade e da impessoalidade inspirando a Administração Pública" (Op. cit., p. 37) - grifos do Autor.

${ }^{182}$ Para Alexy (Op. cit., p. 116-118), a máxima da proporcionalidade significa que a proporcionalidade, com suas três máximas parciais (da adequação, da necessidade e da proporcionalidade em sentido estrito), decorre logicamente da natureza dos princípios. A máxima da proporcionalidade em sentido estrito advém do fato de princípios serem mandamentos de otimização em face das possibilidades jurídicas. As máximas da necessidade e da adequação, por sua vez, decorrem da natureza dos princípios como mandamentos de otimização em face das possibilidades fáticas.

${ }^{183}$ ALEXY, Robert. Op. cit., p. 93. 
fundamentado de forma racional". ${ }^{184}$ Traduz a lei do sopesamento na seguinte fórmula: "Quando maior for o grau de não satisfação ou de afetação de um princípio, tanto maior terá que ser a importância da satisfação do outro". ${ }^{185}$

Devem ser fundamentados os enunciados sobre os graus de afetação e de importância. $\mathrm{O}$ modelo de sopesamento equivale ao princípio da concordância prática e oferece um critério válido, ao associar a lei de colisão à teoria da argumentação jurídica racional. $^{186}$

Olsen sintetiza o sopesamento de forma bastante elucidativa:

(...) Uma restrição aos direitos fundamentais somente estará em conformidade com a proporcionalidade se, simultaneamente, for apta para os fins a que se destina, for a menos gravosa possível para que estes fins sejam atingidos, e cause benefícios superiores aos malefícios eventualmente implicados. ${ }^{187}$

\subsubsection{Alguns princípios de conotação especial em matéria previdenciária}

Destacamos seis princípios que consideramos constituir vetores essenciais no julgamento das causas envolvendo o direito fundamental à previdência e as políticas públicas previdenciárias (englobando a política de Estado e as políticas de Governo), na medida em que possibilitam ao órgão julgador a realização de uma interpretação verdadeiramente social, pois estritamente relacionados ao binômio dignidade humana-democracia.

Tais princípios não excluem a aplicação dos demais admitidos pelo ordenamento jurídico e eles não se sobrepõem em toda e qualquer situação, já que a técnica da ponderação não possibilita o estabelecimento de qualquer hierarquia. A prevalência de um ou outro vai ser analisada caso a caso. No entanto, eles muito nos dizem acerca da proteção social desejada no Estado Democrático de Direito, razão pela qual serão abordados de forma mais detalhada.

O Professor Inocêncio Mártires ressalva de qualquer cotejo axiológico "o valor incondicionado da pessoa humana como valor-fonte de todos os valores, como valor fundante da experiência ética ou, se preferirmos, como princípio e fim de toda ordem jurídica" ${ }^{188}$, entendimento com o qual compartilhamos integralmente na medida em que a

\footnotetext{
${ }^{184}$ Op. cit., p. 165.

${ }^{185}$ Idem, ibidem, p. 167.

${ }^{186}$ Idem, ibidem, p. 173-174.

${ }^{187}$ OLSEN, Ana Carolina Lopes. Op. cit., p. 170.

${ }^{188}$ COELHO, Inocêncio Mártires. Interpretação Constitucional. São Paulo: Saraiva, 2007. p. 73.
} 
dignidade é sempre o valor maior a orientar todas as relações humanas, não podendo ser preterida em hipótese alguma, qualquer que seja o conflito apresentado. ${ }^{189}$ A Constituição Federal de 1988 afirma textualmente que a dignidade da pessoa humana é um dos fundamentos do Estado Democrático de Direito brasileiro.

A maneira mais fácil de apreender o significado da dignidade da pessoa humana é pela exclusão daquilo que não é. Basta nos lembrarmos de situações de violência, de agressão, de humilhação, de fome, de miséria, entre inúmeras outras, para afirmarmos, sem sombra de dúvida, que a dignidade não mora aí. A dignidade é inerente a qualquer pessoa humana, da mais virtuosa até a mais criminosa. Sua existência não depende do seu reconhecimento pelo Direito, sendo a ele anterior e preexistente.

Para Ingo Sarlet, é a

\begin{abstract}
qualidade intrínseca e distintiva reconhecida em cada ser humano que o faz merecedor do mesmo respeito e consideração por parte do Estado e da comunidade, implicando, neste sentido, um complexo de direitos e deveres fundamentais que assegurem a pessoa tanto contra todo e qualquer ato de cunho degradante e desumano, como venham a lhe garantir as condições existenciais mínimas para uma vida saudável, além de propiciar e promover sua participação ativa e corresponsável nos destinos da própria existência e da vida em comunhão com os demais seres humanos. ${ }^{190}$
\end{abstract}

\title{
2.5.3.2.1. Princípio da solidariedade
}

A solidariedade é princípio de grande relevo no Direito Previdenciário. Informa, a bem da verdade, toda a Seguridade Social, como se depreende da leitura do caput do artigo 195 da Constituição Federal de 1998, segundo o qual todos (sociedade e entes públicos União, Estados, Distrito Federal e Municípios) devem para ela contribuir, financiando assim todos os benefícios e serviços prestados nas áreas de Previdência, Saúde e Assistência Social, embora cada com suas especificidades.

A solidariedade é também afirmada pelo legislador constituinte como um dos objetivos fundamentos do nosso país (artigo $3^{\circ}$, inciso I).

\footnotetext{
${ }^{189}$ Ressalte-se que R. Alexy pressupõe a existência de duas normas da dignidade humana: uma regra e um princípio. Não é o princípio, mas sim a regra que ostenta o caráter absoluto; o fato de o princípio da dignidade muitas vezes prevalecer, quando cotejado com outros, causa a impressão equivocada de que também ele é absoluto. No entanto, o princípio da dignidade humana está sujeito à ponderação com os demais princípios admitidos pelo ordenamento (Op. cit., p. 113-114). Como já afirmamos anteriormente, adotamos, neste ponto, posição diversa, apenas registrando a existência das discussões doutrinárias existentes.

${ }^{190}$ SARLET, Op. cit., 2007 a, p. 62.
} 
Seu conceito é tão difícil como o da dignidade humana, pois guarda um profundo senso moral, filosófico e sociológico e sua grandeza não pode ser apreendida pelo Direito.

Não nos arriscaremos aqui, sob pena de cometermos algumas leviandades, a sintetizar a evolução histórica do termo, contentando-nos em apresentar sua relação e importância no âmbito previdenciário.

A ideia de solidariedade está insitamente relacionada à noção de seguro social, segundo o qual indivíduos pertencentes a uma mesma coletividade (por força de trabalho, por força de lei, por força de interesse comum ou outros) firmam um pacto de auxílio mútuo, comprometendo-se a colaborar para a formação de uma poupança coletiva, a ser utilizada em prol de cada um sempre que ocorridas as contingências previamente estabelecidas.

Trata-se de um pacto entre gerações, no qual os trabalhadores de hoje efetuam pagamentos de contribuições que sustentam os trabalhadores do passado, da mesma forma que serão amanhã sustentados pela geração que lhes segue.

Como se vê, a base da solidariedade é a confiança de que todos (aqui incluídos Estado e sociedade) cumprirão o compromisso assumido, "impelindo todas as pessoas a conjugarem esforços para fazer face às contingências sociais, por motivos altruístas ou não, desde que os males que afligem cada indivíduo podem vir a ser sofridos pelos demais e, de qualquer modo, atingem toda a coletividade"191.

\subsection{Princípio da unidade da Constituição}

Ao se deparar com atos normativos infraconstitucionais que supostamente confrontem os postulados constitucionais, cabe ao intérprete dar-lhes o sentido que mais se coaduna com o desejo do legislador constituinte, ao invés de se limitar a declarar a sua inconstitucionalidade. O pressuposto é que a Constituição é soberana, é a lei suprema que fundamenta toda a ordem jurídica.

O intérprete deve buscar sempre a unidade da Constituição, harmonizando as diversas normas que integram o seu texto de forma que lhes dê a máxima eficácia.

De acordo com J. J. Gomes Canotilho:

${ }^{191}$ Pedro Vidal Neto apud CORREIA, Marcus Orione Gonçalves; CORREIA, Érica Paula Barcha. Curso de Direito da Seguridade Social. 2. ed. São Paulo: Saraiva, 2007. p. 99-100. 
(...) o princípio da unidade da constituição é uma exigência da "coerência narrativa" do sistema jurídico. O princípio da unidade, como princípio de decisão, dirige-se aos juízes e a todas as autoridades encarregadas de aplicar as regras e princípios jurídicos, no sentido de as "lerem" e "compreenderem", na medida do possível, como se fossem obras de um só autor, exprimindo uma concepção correcta do direito e da justiça (Dworkin). Neste sentido, embora a Constituição possa ser uma "unidade dividida" isso em nada altera a igualdade hierárquica de todas as suas regras e princípios quanto à sua validade, prevalência normativa e rigidez. ${ }^{192}$

Esse princípio, seguindo as lições do Mestre português, comporta as seguintes dimensões:

(1) o princípio da prevalência da constituição impõe que, dentre as várias possibilidades de interpretação, só deve escolher-se uma interpretação não contrária ao texto e programa da norma ou normas constitucionais; (2) o princípio da conservação de normas afirma que uma norma não deve ser declarada inconstitucional quando, observados os fins da norma, ela pode ser interpretada em conformidade com a constituição; (3) o princípio da exclusão da interpretação conforme a constituição mas "contra legem" impõe que o aplicador de uma norma não pode contrariar a letra e o sentido dessa norma através de uma interpretação conforme a constituição, mesmo através desta interpretação consiga uma concordância entre a norma infraconstitucional e as normas constitucionais. Quando estiverem em causa duas ou mais interpretações - todas em conformidade com a Constituição - deverá procurar-se a interpretação como a melhor orientada para a Constituição. ${ }^{193}$ (grifos do Autor)

O princípio da unidade da Constituição é de grande valia na análise das reformas constitucionais, pois impede que sejam incorporadas no ordenamento normas incompatíveis com o seu conteúdo fundamental, mantendo a organicidade e coerência do sistema jurídico.

\subsection{Princípio da vedação do retrocesso}

Uma vez estabelecido o ordenamento jurídico a reger determinada coletividade, é essencial a segurança jurídica de que suas cláusulas essenciais (ou seu "núcleo duro", como preferem alguns constitucionalistas) não serão suprimidas ou reduzidas. Ou seja, uma vez alcançado determinado patamar, em questão considerada de natureza fundamental, é impossível ao legislador posterior (por meio de emenda constitucional ou legislação infraconstitucional) retroagir.

192 CANOTILHO, José Joaquim Gomes. Direito Constitucional e Teoria da Constituição. 7. ed. (4. reimpr.). Coimbra: Almedina, 2003. p. 1184.

${ }^{193}$ Idem, ibidem, p. 1226-1227. 
O princípio da proibição do retrocesso social, ou a proibição da "contrarrevolução social" ou da "evolução reaccionária", desenvolvido pelo Professor português Joaquim José Gomes Canotilho, significa que:

(...) o núcleo essencial dos direitos sociais já realizado e efectivado através de medidas legislativas ("lei da segurança social", "lei do subsídio de desemprego", "lei do serviço de saúde") deve considerar-se constitucionalmente garantido, sendo inconstitucionais quaisquer medidas estaduais que, sem a criação de outros esquemas alternativos ou compensatórios, se traduzam, na prática, numa "anulação", "revogação" ou "aniquilação" pura a simples desse núcleo essencial. Não se trata, pois, de proibir um retrocesso social captado em termos ideológicos ou formulado em termos gerais ou de garantir em abstracto um status quo social, mas de proteger direitos fundamentais sociais sobretudo no seu núcleo essencial. A liberdade de conformação do legislador e inerente autorreversibilidade têm como limite o núcleo essencial já realizado, sobretudo quando o núcleo essencial se reconduz à garantia do mínimo de existência condigna inerente ao respeito pela dignidade da pessoa humana. (...) ${ }^{194}$

O Direito, como adverte o Professor Marcus Orione Gonçalves Correia,

não é o lugar para se convalidar o retrocesso social, o retrocesso dos direitos individuais e dos direitos sociais. É, sim, o lugar para se fazer o diálogo e a construção de sistemas de direitos individuais e sociais mais fortes, tendentes a uma sociedade mais justa, mais igualitária. $\mathrm{O}$ não retrocesso de natureza social e dos direitos individuais sugere a ideia de uma sociedade mais forte e coesa. É óbvio que o diálogo entre as liberdades individuais e as liberdades sociais vai fazer com que haja novos patamares civilizatórios e constante elevação do conteúdo das relações humanas. A perspectiva tem que ser uma só: a da evolução. $^{195}$

\subsection{Princípio da razoabilidade}

Não obstante implícitos, os princípios da razoabilidade e da proporcionalidade encontram seu fundamento de validade na norma constitucional que assegura o devido processo legal (CRF, artigo 5, LIV) e previsão expressa na Lei $\mathrm{n}^{\circ}$ 9.784/99 (artigo $2^{\circ}$, parágrafo único, IV), entre outros atos normativos infraconstitucionais. ${ }^{196}$

\footnotetext{
${ }^{194}$ CANOTILHO, José Joaquim Gomes. Op. cit., p. 340.

195 CORREIA, Marcus Orione Gonçalves. Interpretação do Direito da Segurança Social. In ROCHA, Daniel Machado; SAVARIS, José Antonio (coords.). Op. cit., p. 263.

${ }^{196}$ Cite-se, a propósito, a doutrina de José R. P. Oliveira: "O direito administrativo brasileiro, de modo inconteste, encontra os seus fundamentos na Constituição Federal, enquanto norma básica do sistema jurídico, que estabelece seus alicerces axiológico-normativos. O Estatuto Fundamental não se constitui pela intenção do legislador constituinte, sem embargo da relevância deste elemento histórico na interpretação da Magna Carta. A Constituição, enquanto norma fundamental da regulação da atividade estatal, resulta da significação objetiva do conjunto sistemático de princípios e regras positivados, explícita ou implicitamente, em seus enunciados. E neles, inequivocamente, dentre os cânones principiológicos regentes da atividade administrativa, encontram-se a razoabilidade e a proporcionalidade" (OLIVEIRA, José Roberto Pimenta. Os
} 
Quando se mostra razoável a escolha de determinada política - entre as várias possíveis - pelo órgão responsável?

Referida escolha é muito menos discricionária do que se costuma imaginar, já que deve obedecer a parâmetros preestabelecidos e alcançar resultados também já definidos. Tal discricionariedade mínima está estritamente ligada à razoabilidade, embora se tratem de conceitos diversos. ${ }^{197}$

Não existe na doutrina pátria um conceito único do termo, razão pela qual alguns deles serão abaixo transcritos para que possamos conhecer a sua abrangência:

\begin{abstract}
O princípio da razoabilidade significa, no contexto jurídico-sistemático da busca do interesse público primário, a exigência de justificada e adequada ponderação administrativa, aberta nos exatos limites constitucionais em que a regra de competência habilitadora autorizar, dos princípios, valores, interesses, bens ou direitos consagrados no ordenamento jurídico, impondo aos agentes administrativos que maximize a proteção jurídica dispensada para cada qual, segundo o peso, importância ou preponderância que venham a adquirir e ostentar em cada caso objeto de decisão. ${ }^{198}$
\end{abstract}

O princípio da razoabilidade indica que a Administração deve procurar os meios mais adequados para atingir os fins propostos. Deve evitar as soluções exageradas, que se aproximam da ilegalidade e realizar os seus atos dentro de critérios racionais, evitando toda sorte de abusos e de arbitrariedades. Por outro lado, deve a Administração procurar realizar o procedimento administrativo sempre da forma mais equilibrada e mais justa, de tal sorte que os administrados, pessoas racionais, possam identificar com facilidade a motivação racional de todos os seus atos. A razoabilidade afasta os exageros, as providências extremadas, as decisões tomadas ao influxo das emoções fortes. Busca sempre, encontrar objetivos razoáveis, que podem ser atingidos por meio de decisões moderadas, totalmente isentas de facciosismo. ${ }^{199}$

princípios da razoabilidade e da proporcionalidade no Direito Administrativo Brasileiro. São Paulo: Malheiros Editores, 2006. p. 205-206).

197 "A razoabilidade interfere, pois, diretamente na forma como a Administração dimensiona e realiza a medida concreta de interesse público capaz de justificar o exercício das atribuições ou prerrogativas funcionais. Está agregada ao núcleo da discricionariedade existente no plano normativo, servindo de parâmetro positivo e negativo da apreciação comparativa que implica o exercício de qualquer esfera de autonomia decisória outorgada aos agentes administrativos. Sua função é impor um limite axiológico ao juízo discricionário do administrador, o qual a norma jurídica autoriza e ao qual recorre como meio necessário para obter a ótima concretização do interesse público, dentro das circunstâncias concretas enfrentadas pela autoridade" (OLIVEIRA, José Roberto Pimenta. Op. cit., p. 183).

${ }^{198}$ OLIVEIRA, José Roberto Pimenta. Op. cit., p. 185.

${ }^{199}$ LIMA, Ruy Cerne. Princípios de Direito Administrativo. 7. ed., rev. e reelaborada por Paula Alberto Pasqualini. São Paulo: Malheiros Editores, 2007. p. 559. 
Em suma: é razoável a opção por determinada política pública sempre que ela se mostrar a mais adequada a atingir à finalidade proposta e respeitar, para tanto, os demais princípios que regem a ordem jurídica.

Ou, de acordo com Helenilson Cunha Pontes, "a decisão razoável é tomada por exclusão. Isto é, mediante o contraste com as irrazoáveis"200.

\subsection{Proporcionalidade}

Foi dito nas linhas acima que a razoabilidade leva em conta a adequação. Mas também está associada à ideia de proporcionalidade, pois não há como considerar uma opção política como razoável se ela é manifestamente desproporcional.

De acordo com José Roberto Pimenta Oliveira,

majoritariamente, a doutrina caminha para o entendimento de que, à luz do atual regime constitucional-administrativo, razoabilidade e proporcionalidade, como princípios, se equiparam, havendo entre elas uma sinonímia de significação jurídica em seu perfil dogmático, detectável na forma como se estruturam os respectivos conteúdos, sob a égide da realidade constitucional configurada pelo Texto Magno de 1988, no qual se encartam e buscam seus fundamentos últimos. $^{201}$

Não obstante a relação estreita entre os princípios, trata-se de termos diversos.

Segundo a doutrina mais abalizada e atual, a proporcionalidade implica o dever de adequação, necessidade e equilíbrio da ação administrativa. ${ }^{202}$

\footnotetext{
${ }^{200}$ Apud OLIVEIRA, José Roberto Pimenta. Op. cit., p. 194.

${ }^{201}$ Para outra corrente doutrinária, aqui representada pelo Professor e Procurador Regional da República Walter Claudius Rothenburg, a proporcionalidade não é um princípio, mas um critério. Confira-se o artigo do autor inscrito na obra "Princípios Processuais Civis na Constituição" (NETO, Olavo de Oliveira e LOPES, Maria Elizabeth de Castro).

${ }^{202}$ De acordo com José R. Pimenta Oliveira (Op. cit., p. 190-191): “A adequação significa que a medida administrativa tomada deve apresentar uma linha de causalidade ajustada à finalidade que se propõe atingir. A decisão administrativa é idônea se através de sua prática torna-se mais próximo o objetivo público colimado, ou seja, ela não o dificulta nem se revela perante o mesmo indiferente. Para ser adequada, o grau de eficácia da medida não necessita ser total, mas apenas parcial, recusando-se validade neste teste apenas as medidas totalmente inoperantes para atingir o desiderato perseguido."

(...)

"A necessidade significa que, para além do fomento da finalidade pública, a medida, dentro do elenco das possibilidades abstratas comportadas pela ordem jurídica para o caso vertente, deve ser a menos lesiva. Tem como pressuposto a realização de juízo paralelo de idoneidade, a fim de contrastar a adequação das medidas alternativas.

Diferente da adequação, o teste centraliza-se em uma operação de comparação, de natureza complexa, porquanto implica qualificar o tipo de lesão de cada medida, medir sua intensidade, qualificar os bens ou interesses afetados e, eventualmente, sendo de natureza distinta, ponderá-los. Disso resulta que, para verificação e discussão da necessidade, são utilizados instrumentos de medição quantitativa (quantas pessoas, que extensão, quanto tempo, quanto custa), de qualificação técnica-jurídica e, em certos casos, de ponderação."
} 
A adequação busca responder a seguinte indagação: "o meio escolhido contribui para a obtenção do resultado pretendido?”. Não precisa ser absoluta, vale dizer, “o exame da idoneidade da medida restritiva deve ser feito sob o enfoque negativo; apenas quando inequivocamente se apresentar como inidônea para alcançar seu objetivo é que a lei deve ser anulada". ${ }^{203} \mathrm{O}$ critério da adequação não significa que a medida precisa ser a mais adequada entre as várias possíveis, mas suficientemente adequada para alcançar os fins a que se propõe.

A necessidade, por sua vez, significa que a medida é indispensável para a conservação do direito fundamental em questão e deve ser a menos gravosa possível. Para Lerche $^{204}$, trata-se do meio mais idôneo e a menor restrição possível.

A necessidade é limitada pela adequação, vez que "apenas o que é adequado pode ser necessário, mas o que é necessário não pode ser inadequado". ${ }^{205}$

Por fim, a proporcionalidade em sentido estrito pretende aferir se "o meio utilizado encontra-se em razoável proporção com o fim perseguido". ${ }^{206}$ Entra em jogo, aqui, a ponderação entre os valores em discussão.

No âmbito doutrinário, são quatro as diferenças apontadas entre os princípios:

Em primeiro lugar, na proporcionalidade está presente uma exigência de motivação racional da decisão que aplica o princípio, "sensivelmente maior e diferente" da exigida pelo princípio da razoabilidade, por conta dos três escalões da primeira e mera vedação, pela segunda, do irracional, inaceitável ou irrazoável. Em segundo lugar, entre os princípios, há distinção de conteúdo. A proporcionalidade pressupõe, "notadamente, mas não exclusivamente", um juízo acerca da relação meio-fim, ao passo que a razoabilidade opera com a exigência de decisão jurídica racionalmente motivada, com a apreciação dos interesses concretamente envolvidos, e a qualificação da mesma dentro do rol de decisões igualmente razoáveis.

Em terceiro lugar, descortina-se uma diferença quanto à natureza. A razoabilidade é decifrada como princípio geral de interpretação que veda a concretização do inaceitável socialmente, do irracional e do irrazoável. Já a proporcionalidade é considerada, além de princípio de interpretação, princípio

(...)

"Por fim, 'a vertente do equilíbrio (ou da proporcionalidade em sentido estrito) exige que os benefícios que se esperem alcançar com uma medida administrativa adequada e necessária suplantem, à luz de certos parâmetros materiais, os custos que ela por certo acarretará'.

Implicando a decisão administrativa uma escolha valorativa, pretende-se, na análise deste último escalão normativo, saber se foi adotado o grau tolerável em termos de realização e restrição de interesses e bens jurídicos. Uma operação de ponderação ocupa o aspecto central da proporcionalidade em sentido estrito. $\mathrm{O}$ equilíbrio ou tolerabilidade da medida resulta de uma apreciação irremovivelmente concreta da situação em que incide o princípio" (grifos do Autor).

${ }^{203}$ BARROS, Suzana de Toledo. O princípio da proporcionalidade e o controle de constitucionalidade das leis restritivas de direitos fundamentais. 2. ed. Brasília: Brasília Jurídica, 2000. p. 76 e 78.

${ }^{204}$ Apud BARROS, Suzana. Op. cit., p. 79.

205 A frase é de PIEROTH e SCHLINK, citados por Gilmar Ferreira Mendes (apud BARROS, Suzana de Toledo. Op. cit., p. 81)

${ }^{206}$ BARROS, Suzana de Toledo. Op. cit., p. 83. 
jurídico material derivado da consagração constitucional do Estado Democrático de Direito.

Em quarto lugar, distinguem-se ainda em relação às respectivas funções eficaciais, segundo a concepção de Tércio Sampaio. A razoabilidade é norma jurídica com exclusiva função de bloqueio. A proporcionalidade, além da função de bloqueio (vedação ao arbítrio) exerce função de resguardo, isto é, "de norma que se exige e assegura a concretização dos interesses constitucionalmente consagrados, na melhor medida possível”. ${ }^{207}$

O princípio da proporcionalidade é retratado com perfeição na célebre frase de JELLINEK $^{208}$ : "não se abatem pardais disparando canhões".

\subsection{Eficiência}

A eficiência é a palavra mestra a orientar as reformas administrativas ocorridas nos últimos tempos. Foi expressamente introduzida no texto constitucional por força da Emenda $n^{\circ}$ 19, de 1998, passando a ser uma das diretrizes informadoras da Administração Pública, ao lado da legalidade, da moralidade, da impessoalidade e da publicidade. Também tem sido utilizada pelo Poder Judiciário para a análise dos atos editados pelo Poder Legislativo. ${ }^{209}$

De acordo com Odete Medauar, "o princípio da eficiência determina que a Administração deve agir, de modo rápido e preciso, para produzir resultados que satisfaçam as necessidades da população. Eficiência contrapõe-se a lentidão, a descaso, a negligência, a omissão - características habituais da Administração Pública brasileira, com raras exceções". ${ }^{210}$

A política pública (em sua dupla dimensão) é eficiente quando atinge os objetivos a que se reserva cumprir, com observância das regras de procedimento. Se considerada nestes termos, a eficiência só tem a agregar vez que estritamente relacionada com a melhoria das condições da coletividade. Como ressaltado por José Antonio Savaris, "se

\footnotetext{
${ }^{207}$ Apontamentos feitos por Helenilson Cunha Pontes (apud OLIVEIRA, José Roberto Pimenta. Op. cit., p. 194-195).

${ }^{208}$ Apud BARROS, Suzana de Toledo. Op. cit., p. 44.

${ }^{209}$ A Lei no ${ }^{\circ} .784 / 99$ (Lei do Procedimento Administrativo) consagra o princípio da eficiência, ao determinar a: (i) "adequação entre meios e fins, vedada a imposição de obrigações, restrições e sanções em medida superior àquelas estritamente necessárias ao atendimento do interesse público" (artigo $2^{\circ}$, VI) e (ii) a adoção de formas simples, suficientes para propiciar adequado grau de certeza, segurança e respeito aos direitos dos administrados" (artigo 2º IX). A Lei no 8.987/95 (Lei de Concessão de Serviços Públicos), por sua vez, estabelece que "serviço adequado é o que satisfaz as condições de regularidade, continuidade, eficiência, segurança, atualidade, generalidade, cortesia na sua prestação e modicidade das tarifas" (artigo $6^{\circ}, \S 1^{\circ}$ ).

${ }^{210}$ MEDAUAR, Odete. Direito Administrativo Moderno. 10. ed. São Paulo: Revista dos Tribunais, 2006. p. 145 .
} 
eficiência é conformar a prática administrativa com os princípios fundamentais que a regem, nunca antes se precisou tanto dela". Mas adverte o Autor:

\begin{abstract}
Se a eficiência guarda, contudo, o significado de metas/resultados e de racionalização dos serviços públicos para o máximo de produtividade - noção oferecida por um dos enfoques do modelo toyotista de redução de custos e produção enxuta just in time; se a Administração Pública não se perde em formas como antes, mas também não avalia seus resultados a partir da qualidade dos serviços, senão pela performance quantitativa, persiste em ter a si como referência primária, não ainda o cidadão. ${ }^{211}$
\end{abstract}

Em resumo, a utilização da eficiência como princípio orientador das políticas públicas, por si só, não possui qualquer conotação negativa, contanto que não se limite exclusivamente ao aspecto econômico.

Infelizmente, não foi o aspecto positivo do princípio da eficiência acima retratado que se pretendeu introduzir como princípio constitucional, mas meramente a eficiência econômica, ou seja, a busca incessante pela redução dos custos.

\title{
2.5.4. Limites
}

Os estudos doutrinários afirmam, com alguma frequência, que o controle judicial de políticas públicas é uma exceção ao princípio da independência e harmonia entre os Poderes porque o Judiciário acaba por intervir em função típica de outro poder.

Há alguma incorreção neste pensar, já que a função típica do Judiciário é ser o guardião da ordem jurídica. Assim, deve o juiz - quando acionado - se manifestar para dizer se o ato impugnado, seja ele praticado por particular ou pelo próprio Poder Público, fere ou não as normas jurídicas em vigor.

A rigor, quem desborda de suas funções é o órgão político (do Legislativo ou do Executivo) que formula política pública em desacordo com o ordenamento jurídico.

Por tal razão, é de fundamental importância ressaltar que quando determinado Poder exerce sua função típica, dentro dos limites fixados, não se justifica a intervenção de outro Poder. Desta forma, ao realizar o controle de política pública (cujo pressuposto é a violação da ordem jurídica), também cabe ao Judiciário não ultrapassar as fronteiras onde pode legítima e legalmente atuar.

Daí o cuidado que deve ter, ao afastar a aplicação de determinada política pública, por manifesta inconstitucionalidade, em não "criar" uma nova, já que esta não é a sua

${ }^{211}$ SAVARIS, José Antonio. Direito Processual Previdenciário. Curitiba: Juruá, 2008a. p. 98. 
função típica. Definir tais limites é a grande questão que hoje se tem colocado ao Poder Judiciário e a todos os operadores do Direito.

Duas são as situações possíveis: (i) o Poder Judiciário é instado a se manifestar sobre os atos normativos já formulados pelos poderes competentes; (ii) o Poder Judiciário é provocado a suprir a omissão (total ou parcial) do órgão competente.

No primeiro caso, valendo-se dos princípios consagrados pela ordem constitucional, compete ao juiz verificar se os atos normativos editados e impugnados estão em consonância com o direito fundamental à previdência social, conferindo-lhe eficácia ou se, ao contrário, o restringe ou limita.

Como o juiz não é um técnico habilitado em questões específicas, quando defrontado com discussões eminentemente técnicas, deve se valer dos meios processuais cabíveis e dos conhecimentos especializados de profissionais a fim de formar seu convencimento.

Vamos recorrer a um exemplo bastante comum em matéria previdenciária e que bem elucida a forma de intervenção judicial em casos assim.

De acordo com o $\S 4^{\circ}$ do artigo 201 da Constituição Federal (com a redação dada pela Emenda Constitucional $n^{\circ}$ 20/98), "é assegurado o reajustamento dos benefícios para preservar-lhes, em caráter permanente, o valor real, conforme critérios definidos em lei”.

Foi claro o legislador constituinte ao delegar ao legislador infraconstitucional competência para disciplinar a matéria, com a ressalva expressa de que deve ser preservado o valor real do benefício.

A matéria foi inicialmente disciplinada pelo artigo 41 da Lei $\mathrm{n}^{\circ}$ 8.213/91 e atualmente o reajuste de benefícios é tratado pelo artigo 41-A da lei referida, introduzido pela Lei ${ }^{\circ}$ 11.430/2008 (resultante da conversão da Medida Provisória $n^{\circ}$ 316/2006) que revogou o antigo artigo 41.

Consta do artigo 41-A que

\footnotetext{
o valor dos benefícios em manutenção será reajustado, anualmente, na mesma data do reajuste do salário mínimo, pro rata, de acordo com suas respectivas datas de início ou do último reajustamento, com base no Índice Brasileiro de Preços ao Consumidor - INPC, apurado pela Fundação Instituto Brasileiro de Geografia e Estatística - IBGE.
}

A justificativa utilizada pelo legislador, inscrita na Exposição de Motivos da Medida Provisória no 316, é a de que "a indicação para que seja utilizado o INPC se deve ao fato de que este índice é o que melhor reflete o poder de compra dos trabalhadores na 
faixa de um a oito salários mínimos, onde se insere a totalidade dos trabalhadores do Regime Geral de Previdência Social e é o que vem sendo aplicado nos últimos anos”.

Desde a edição da Lei $n^{\circ}$ 8.213/91 e até os dias atuais, inúmeras ações são ajuizadas visando discutir os índices legais fixados, ao fundamento de que não refletem o fenômeno inflacionário ocorrido.

Dois caminhos são possíveis ao juiz tomar: $(i)$ julgar antecipadamente a lide, sob a alegação de que se trata de matéria unicamente de direito, e julgar improcedente a pretensão, já que o legislador ordinário retirou da Constituição Federal competência para disciplinar a matéria e elegeu um dos índices possíveis, não necessariamente o melhor e nem o pior; (ii) possibilitar às partes a produção de provas e verificar se a matéria em discussão demanda esclarecimentos de profissionais especializados, determinando a realização da instrução probatória, ainda que de ofício.

No exemplo citado, se a perícia técnica concluir que o índice adotado pelo legislador, embora não seja o "melhor do mercado", recompõe de forma suficiente o valor da moeda e preserva o valor real do benefício, o órgão julgador terá maiores subsídios para indeferir a pretensão, vez que efetivamente constatado que a política pública de reajuste está de acordo com a norma constitucional.

Ao contrário, caso a perícia apure que o índice eleito é absolutamente divorciado da realidade e não mantém o valor de compra do benefício, cabe ao juiz afastá-lo por ofensa à norma constitucional. É neste sentido que o Supremo Tribunal Federal tem orientado suas decisões ao apreciar questões relativas ao reajuste dos benefícios previdenciários. ${ }^{212}$

\footnotetext{
${ }^{212}$ Confira-se, a propósito, as seguintes ementas:

“(...)

II - A presunção de constitucionalidade da legislação infraconstitucional realizadora do reajuste previsto no art. 201, § $4^{\circ}$, C.F., somente pode ser elidida mediante demonstração da impropriedade do percentual adotado para o reajuste. Os percentuais adotados excederam os índices do INPC ou destes ficaram abaixo, num dos exercícios, em percentual desprezível e explicável, certo que o INPC é o índice mais adequado para o reajuste dos benefícios, já que o IGP-DI melhor serve para preços no atacado, porque retrata, basicamente, a variação de preços no setor empresarial brasileiro. (...)" - STF, RE 376.846-8/SC, Relator Ministro Carlos Velloso, DJ 02/04/2004.

"EMENTA: Previdência Social.

- O artigo 201, $\S 2^{\circ}$, da parte permanente da Constituição dispõe que "é assegurado o reajustamento dos benefícios para preservar-lhes, em caráter permanente, o valor real, conforme critérios definidos em lei”. Portanto, deixou para a legislação ordinária o estabelecimento dos critérios para essa preservação. E, para isso, a legislação tem adotado indexadores que visam a recompor os valores em face da inflação, não dando margem, evidentemente, à caracterização da inconstitucionalidade dela a alegação de que, pela variação que pode ocorrer entre esses índices pelo critério de sua aferição, se deva ter por inconstitucional um que tenha sido menos favorável que outro. Para essa declaração de inconstitucionalidade seria mister que se demonstrasse que o índice estabelecido em lei para esse fim é manifestamente inadequado, o que não ocorre no caso. Note-se, por fim, que a legislação infraconstitucional não poderia adotar como critério para essa preservação de valores a vinculação ao salário-mínimo, visto como está ela vedada para qualquer fim pelo inciso IV do artigo $7^{\circ}$ da Constituição.
} 
A dúvida é o que colocar em substituição ao índice afastado, já que o benefício deve ser reajustado e ter seu valor real preservado.

Neste caso, o juiz deve elaborar quesitos ao Perito e indagar quais são os índices existentes que traduzem o fenômeno inflacionário e eleger um deles, de forma fundamentada, a ser aplicado apenas ao benefício do Autor da ação.

Não há violação ao princípio da isonomia, pois não se está negando o mesmo direito aos demais segurados, mas apenas limitando os efeitos da decisão a quem postulou. Nada impede que cada segurado ingresse com sua própria ação, mas os resultados podem ser bem diversos.

A intervenção judicial mostra-se bem mais controvertida nos casos em que os poderes competentes para a edição de um ato não o fazem ou o fazem de forma incompleta. Quanto pode o juiz fazer quando instado a suprir a omissão?

O julgamento da Arguição de Preceito Fundamental no 45-9 foi um importante marco na discussão sobre o controle judicial de políticas públicas, vez que admitida de forma expressa pelo Supremo Tribunal Federal a intervenção ativa do Poder Judiciário na formulação e implementação de políticas públicas diretamente relacionadas à concretização de direitos fundamentais, quando configurada a omissão do Poder responsável. $^{213}$

\begin{abstract}
Arguição de descumprimento de preceito fundamental. A questão da legitimidade constitucional ou do controle e da intervenção do Poder Judiciário em tema de implementação de políticas públicas, quando configurada hipótese de abusividade governamental. Dimensão política da jurisdição constitucional atribuída ao Supremo Tribunal Federal. Inoponibilidade do arbítrio estatal à efetivação dos direitos sociais, econômicos e culturais. Caráter relativo da liberdade de conformação do legislador. Considerações em torno da reserva do possível. Necessidade de preservação, em favor dos indivíduos, da integridade e da intangibilidade do núcleo consubstanciador do mínimo existencial.
\end{abstract}

Recurso extraordinário não conhecido." - STF, RE 219.880-0/RN, Relator Ministro Moreira Alves, DJ 06/08/1999.

213 "É certo que não se inclui, ordinariamente, no âmbito das funções institucionais do Poder Judiciário e nas desta Suprema Corte, em especial - a atribuição de formular e implementar políticas públicas (ANDRADE, José Carlos Vieira de. Os direitos fundamentais na constituição portuguesa de 1976, p. 207, item n. 05, 1987, Almedina, Coimbra), pois, nesse domínio, o encargo reside, primariamente, nos Poderes Legislativo e Executivo. Tal incumbência, no entanto, embora em bases excepcionais, poderá atribuir-se ao Poder Judiciário, se e quando os órgãos estatais competentes, por descumprirem os encargos político-jurídicos que sobre eles incidem, vierem a comprometer, com tal comportamento, a eficácia e a integridade de direitos individuais e/ou coletivos impregnados de estatura constitucional, ainda que derivados de cláusulas revestidas de conteúdo programático. Cabe assinalar, presente esse contexto - conforme já proclamou esta Suprema Corte - que o caráter programático das regras inscritas no texto da Carta Política 'não pode converter-se em promessa constitucional inconsequente, sob pena de o Poder Público, fraudando justas expectativas nele depositadas pela coletividade, substituir, de maneira ilegítima, o cumprimento de seu impostergável dever, por um gesto irresponsável de infidelidade governamental ao que determina a própria Lei do Estado"” (ADPF 45-9, trecho do voto do Relator, Ministro Celso de Mello). 
Viabilidade instrumental da arguição de descumprimento no processo de concretização das liberdades positivas (direitos constitucionais de segunda geração). ${ }^{214}$

De acordo com a decisão, três são os requisitos exigidos para que o Judiciário possa intervir de forma ativa: $(i)$ necessidade de preservar o 'mínimo existencial' garantido ao cidadão pelo texto constitucional; ( $i$ i) razoabilidade da pretensão deduzida em face do Poder Público e (iii) disponibilidade financeira do Estado para tornar efetivas as prestações dele reclamadas. ${ }^{215}$

A disponibilidade financeira do Estado é o ponto que mais dificuldades traz aos operadores do Direito, especialmente aos juízes, dada a estreita vinculação com a questão orçamentária, matéria da alçada dos Poderes Executivo e Legislativo. ${ }^{216}$

No tópico a seguir trataremos especificamente do tema 'reserva do possível'. No entanto, por ora, tendo em vista os limites que se pretendem traçar à atuação judicial no controle de políticas públicas, duas soluções judiciais se mostram possíveis quando efetivamente constatada a insuficiência de recursos - a ser provada pela Administração, na forma do artigo 333, inciso II, do Código de Processo Civil: (i) em caso de não urgência, determinar ao Poder responsável que

\begin{abstract}
faça constar da próxima proposta orçamentária a verba necessária à implementação da política pública. E, como a lei orçamentária não é vinculante, permitindo transposição de verbas, o Judiciário ainda deverá determinar, em caso de descumprimento do orçamento, a obrigação de fazer consistente na implementação de determinada política pública (a construção de uma escola ou de um hospital, por exemplo). Para tanto, o $\$ 5^{\circ}$ do art. 461 do Código de Processo Penal servirá perfeitamente para atingir o objetivo final almejado ${ }^{217} /^{218}$;
\end{abstract}

(ii) em caso de demonstração da urgência da medida judicial postulada, não sendo possível aguardar o ano seguinte para a concessão do direito, cabe ao juiz então proceder à ponderação entre os princípios e valores envolvidos e fazer prevalecer o que mais se coaduna com a ordem constitucional, determinando as medidas necessárias a serem tomadas no caso concreto.

\footnotetext{
${ }^{214}$ ADPF 45-9.

${ }^{215}$ GRINOVER, Ada Pellegrini. O controle de políticas públicas pelo Poder Judiciário. In GRINOVER, Ada Pellegrini. O Processo: Estudos \& Pareceres. 2. ed. rev. e ampl. São Paulo: Editora DPJ, 2009a. p. 42.

${ }^{216}$ Confiram-se os artigos 165 a 169 da Constituição Federal.

${ }^{217}$ GRINOVER, Ada Pellegrini. Op. cit., 2009a. p. 48.

${ }^{218}$ Neste sentido, ainda, Fernando Sacury Scaff (Sentenças aditivas, direitos sociais e reserva do possível. In SARLET, Ingo Wolfang; TIMM, Luciano Benetti (orgs.). Direitos Fundamentais: orçamento e 'reserva do possível'. Porto Alegre: Livraria do Advogado, 2008. p. 158), para quem “o equacionamento financeiro da determinação judicial para desembolso de parcelas futuras não gera uma dificuldade financeira, em face do sistema orçamentário brasileiro".
} 
O entendimento aqui defendido é que o Poder Judiciário atua de forma subsidiária, mas tem o dever - e não a opção - de agir.

Assim, dependendo da questão em discussão e da urgência da medida - a ser demonstrada caso a caso - ao Judiciário apenas restam dois caminhos: (i) em caso de não demonstração da urgência, determinar ao Poder competente que implemente a política pública no exercício seguinte, reservando as verbas orçamentárias correspondentes; (ii) em caso de necessidade imediata, determinar as medidas necessárias à concretização do direito invocado.

No entanto, não se admite a omissão do Judiciário perante a omissão dos outros Poderes. Se o direito é fundamental, deve ser efetivado. ${ }^{219}$

$\mathrm{Na}$ hipótese narrada, a via processual adequada é o mandado de injunção, pelo qual é possível o exercício do controle de constitucionalidade difuso por omissão. A utilização da ação direta de inconstitucionalidade por omissão apenas é cabível excepcionalmente, vez que é uma forma de controle abstrato, sem referência a um caso concreto, ou seja, não há a urgência necessária a justificar a regulamentação da matéria pelo Judiciário.

A omissão por parte do Poder Legislativo tem sido considerada uma grave violação à Constituição Federal pelo Supremo Tribunal Federal, como demonstra a seguinte ementa:

\begin{abstract}
(...)
- A omissão do Estado - que deixa de cumprir, em maior ou em menor extensão, a imposição ditada pelo texto constitucional - qualifica-se como comportamento revestido da maior gravidade político-jurídica, eis que, mediante inércia, o Poder Público também desrespeita a Constituição, também compromete a eficácia da declaração constitucional de direitos e também impede, por ausência de medidas concretizadoras, a própria aplicabilidade dos postulados e princípios da Lei Fundamental.

- As situações configuradoras de omissão inconstitucional, ainda que se cuide de omissão parcial, refletem comportamento estatal que deve ser repelido, pois a inércia do Estado - além de gerar a erosão da própria consciência constitucional - qualifica-se, perigosamente, como um dos processos informais de mudança
\end{abstract}

${ }^{219}$ Neste sentido, ainda, os ensinamentos de Luiz Guilherme Marinoni (Teoria Geral do Processo. 3. ed. rev. e atual. São Paulo: Revista dos Tribunais, 2008. p. 65-66): "Veja-se que um direito fundamental pode depender de uma regra que lhe dê proteção. Nessa hipótese, configurando-se a omissão legislativa, há verdadeira omissão de proteção, devida pelo legislador. Essa omissão pode ser reconhecida judicialmente, quando o juiz deverá determinar a supressão da omissão para dar proteção ao direito fundamental. $\mathrm{O}$ problema que pode existir, nessa ocasião, relaciona-se com a "forma" mediante a qual o juiz determinará a proteção. Se o direito fundamental não pode ficar sem proteção, o direito que restou intocado pela omissão legal certamente só deverá suportar a medida que, dando proteção ao direito, o sujeite à menor restrição possível.

(...)

Não obstante, assim como o controle da constitucionalidade da regra positiva é imprescindível a qualquer juiz, o controle da omissão que impede a efetivação de um direito fundamental deve ser utilizado por todos os magistrados. Aliás, como o direito fundamental à tutela efetiva incide sobre o próprio juiz, seria completamente irracional dele retirar a possibilidade de dar utilidade à tarefa que lhe foi atribuída pela Constituição". 
ilegítima da Constituição, expondo-se, por isso mesmo, à censura do Poder Judiciário. Precedentes: RTJ 162/877-879, Rel. Min. CELSO DE MELLO - RTJ 185/794-796, Rel. Min. CELSO DE MELLO.

O DESPREZO ESTATAL POR UMA CONSTITUIÇÃO DEMOCRÁTICA REVELA-SE INCOMPATÍVEL COM O SENTIMENTO CONSTITUCIONAL RESULTANTE DA VOLUNTÁRIA ADESÃO POPULAR À AUTORIDADE NORMATIVA DA LEI FUNDAMENTAL.

- A violação negativa do texto constitucional, resultante da situação de inatividade do Poder Público - que deixa de cumprir ou se abstém de prestar o que lhe ordena a Lei Fundamental - representa, notadamente em tema de direitos e liberdades de segunda geração (direitos econômicos, sociais e culturais), um inaceitável processo de desrespeito à Constituição, o que deforma a vontade soberana do poder constituinte e que traduz conduta estatal incompatível com o valor ético-jurídico do sentimento constitucional, cuja prevalência, no âmbito da coletividade, revela-se fator capaz de atribuir, no Estatuto Político, o necessário e indispensável coeficiente de legitimidade social. (...)

(STF, ADIN 1.442-1/DF, Relator Ministro Celso de Mello, DJ 29/04/2005).

\subsection{Reserva do possível}

As políticas públicas, por serem instrumentos de concretização dos direitos sociais, possuem custos e exigem necessariamente a utilização de recursos do Estado.

Daí por que se tornou de uso comum afirmar que "dinheiro não nasce em árvore", não bastando a previsão legal de um direito e o desejo em efetivá-lo, sendo essencial demonstrar a fonte de custeio, ou seja, de onde será tirada a verba necessária para a execução da política pública.

Também é de uso popular a ideia de que "o Judiciário não é dono da chave do cofre, portanto não pode determinar como o dinheiro deve ser gasto, atribuição típica do Poder Executivo".

A escassez de recursos é o principal argumento utilizado para afastar ou limitar ao máximo o controle judicial das políticas públicas, em respeito ao princípio da independência entre os Poderes.

A teoria do custo dos direitos ganhou realce após a publicação da obra The Cost of Rights, de Stephen Holmes e Cass Sunstein, em 1999, segundo a qual todos os direitos individuais e sociais - importam em custos por parte do Estado para serem concretizados. No entanto, o aporte de recursos necessário para a implementação de uma política pública de saúde, por exemplo, é substancialmente mais elevado que aquele necessário para o exercício do direito de propriedade, razão pela qual a questão da escassez de recursos ganhou maior destaque com o Estado Social. 
A ideia central defendida pelos autores americanos é a de que "nada que custe dinheiro pode ser absoluto" ${ }^{, 20}$, vale dizer, os direitos fundamentais (individuais e sociais) só existem se houver disponibilidade econômica que permita a sua efetivação. Se não, são meras palavras vazias.

A limitação orçamentária é parte integrante do direito fundamental, donde se conclui que a inexistência de recursos não permite o reconhecimento da existência do direito. Desta forma, os direitos enunciados no texto constitucional são condicionais.

Como bem ressalta Ana Carolina Olsen, esta doutrina torna legítima a prevalência da dimensão econômica sobre a dimensão jurídica, na medida em que "a escassez de recursos deixa de ser um elemento externo dos direitos, que pode comprometer sua efetividade, para ser considerada como elemento intrínseco. A questão econômica foi trazida para o próprio âmago dos direitos - sem recursos eles deixam de existir.",221

Ao buscarmos a origem da expressão reserva do possível, verificamos que o alcance dado pela doutrina pátria não guarda consonância com o sentido originário. ${ }^{222}$ Vejamos.

A discussão foi inicialmente travada no ano de 1970, na Alemanha.

O objeto da lide era a obrigação do Estado em fornecer vagas de ensino superior a dois cidadãos interessados em realizar o curso de Medicina. As regras legais estaduais restringiam o acesso, razão pela qual o caso ficou conhecido como numerus clausus.

O Tribunal Constitucional considerou constitucional a restrição, sob a alegação de que o Estado já havia fixado um número razoável de vagas no ensino superior, não sendo obrigado pela norma constitucional a acolher todos os estudantes que pretendam cursar a universidade. Não se discutiu ali, especificamente, a escassez de recursos, pois o que estava em debate era se as vagas oferecidas atendiam a um critério razoável. Se havia razoabilidade na escolha, desarrazoável seria retirar verbas de outros programas sociais, também amparados pela ordem jurídica, para atender unicamente aos gastos com educação, já suficientemente destinados.

\footnotetext{
${ }^{220}$ OLSEN, Ana Carolina Lopes. Op. cit., p. 187.

${ }^{221}$ Ibidem, p. 187.

${ }^{222}$ Incorre-se, assim, no perigo ressaltado por Andreas Krell (Op. cit., p. 41), para quem: "as instituições jurídico-constitucionais de um povo somente podem ser compreendidas a partir das ideias morais e dos princípios políticos que o animam e do sentido histórico com que se desenvolveram, sendo impossível 'transportar-se um instituto jurídico de uma sociedade para outra, sem se levar em conta os condicionamentos a que estão sujeitos todos os modelos jurídicos"”.
} 
Por aí se vê que o leading case, usualmente invocado em estudos doutrinários e decisões judiciais, diz respeito mais à aplicação da razoabilidade na eleição das escolhas do que à disponibilidade de recursos.

De mais a mais, cumpre observar que não consta da Lei Fundamental alemã a proteção expressa aos direitos sociais $^{223}$, situação bastante diversa da brasileira, especialmente após a promulgação da Constituição Federal de 1988.

O texto constitucional de 1988 expressamente reconhece a fundamentabilidade dos direitos sociais, lado a lado com os direitos individuais, não impondo restrições diversas ao seu exercício, como o faz a Constituição de Portugal de 1976.

Não obstante, a reserva do possível foi traduzida e incorporada pela doutrina pátria unicamente como a relação entre a disponibilidade de recursos e o custo dos direitos, em outros termos como a reserva do financeiramente possível. ${ }^{224}$

Segundo Olsen,

\begin{abstract}
a reserva do possível é uma condição de realidade que determina a submissão dos direitos fundamentais prestacionais aos recursos existentes. Todavia, não se trata de simplesmente afirmar que os direitos fundamentais existem no mundo jurídico, mas só encontrarão efetividade quando houver recursos suficientes em caixa, disponíveis pelos poderes públicos, para realizar as prestações neles previstas. A questão não é tão simples. Ainda que não se possa exigir o logicamente impossível, quando se busca a efetivação de um direito fundamental prestacional é preciso ter em mente qual a responsabilidade dos órgãos públicos para com a sua efetivação. A Constituição, ao alçar determinados direitos à condição de direitos fundamentais, e determinar expressamente a alocação de recursos para sua realização, admite o argumento da reserva do possível como exceção, e não como regra. Os direitos não existem porque há recursos disponíveis. Sua mera existência determina, por si só, a alocação dos recursos necessários à sua realização. Ainda que não se possa perder a dimensão da realidade, é válido ter em consideração que os direitos fundamentais sociais primeiramente existem, foram reconhecidos como tais, e por essa razão devem ser concretizados, de modo que impõem a alocação dos recursos necessários a esta concretização. ${ }^{225}$
\end{abstract}

A invocação deste postulado só é possível quando: (i) a pretensão formulada encontrar respaldo no ordenamento jurídico; (ii) houver disponibilidade fática e jurídica

\footnotetext{
${ }^{223}$ Ainda segundo Andreas Krell, isto se deve às más experiências decorrentes da Constituição de Weimar, de 1919, considerada por muitos doutrinadores alemães como uma Carta 'fracassada', vez que os direitos sociais ali previstos foram utilizados em sentido inverso ao pretendido. Afirma o Autor que "os modernos artigos da Carta de Weimar sobre direitos sociais foram 'ridicularizados' por parte dos integrantes da extrema-direita e esquerda política, como 'promessas vazias do Estado burguês' e 'contos de lenda'. Como consequência, o legislador fundamental de 1949 renunciou deliberadamente à formulação de normas que conferem direitos subjetivos a prestações positivas por parte do Estado. Os direitos sociais, cuja eficácia sempre depende de vários fatores econômicos e políticos, ficaram de fora" (KRELL, Andreas J. Op. cit., p. 46).

${ }^{224}$ OLSEN, Ana Carolina Lopes. Op. cit., p. 243.

${ }^{225}$ OLSEN, Ana Carolina Lopes. Op. cit., p. 212.
} 
dos recursos necessários, ou seja, existirem recursos e o órgão público acionado puder deles dispor.

O cerne da questão está na alocação dada aos recursos existentes, sabidamente limitados.

A Constituição fornece todos os parâmetros necessários para a análise da compatibilidade entre as escolhas feitas pelo agente político e as imposições constitucionais destinadas a assegurar a efetivação dos valores e direitos mais caros da sociedade.

Cabe ao órgão julgador determinar ao Poder Público que comprove a veracidade de suas alegações (inexistência de recursos), demonstrando para onde foram alocados os recursos existentes. De posse destas informações, deve o juiz verificar se a destinação dada pelo órgão público encontra guarida na Constituição. Em caso negativo, constitui poderdever do juiz obstar a realização do gasto manifestamente inconstitucional.

O problema surge quando não constam do orçamento as despesas necessárias para a efetivação de um determinado direito fundamental e o Poder Judiciário é instado a se manifestar.

Pode o juiz fazê-lo em favor de uma única pessoa, quando existem milhares de outras na mesma situação mas que não ingressaram em juízo à justiça? Pode o juiz, de forma indireta, impedir que outras políticas públicas se realizem? $?^{226}$

De acordo com Olsen,

\begin{abstract}
quando o que está em pauta é a realização de direitos fundamentais necessários à realização da dignidade da pessoa humana, parece que o conceito a ser enfraquecido é de discricionariedade política na alocação de recursos, e não o de controle jurisdicional. (...) A Constituição Dirigente determina o cumprimento da norma, de modo que este cumprimento deve ser a premissa, para a qual somente a escassez natural de recursos, devidamente comprovada, pode ser aceita como exceção que exonera o cumprimento da obrigação. A escassez artificial, fruto de uma escolha política, não pode ser oposta como justificação do descumprimento dos direitos fundamentais. ${ }^{227}$
\end{abstract}

No julgamento da ADPF n ${ }^{\circ}$ 45-9/DF, o Supremo Tribunal Federal assim tratou da reserva do possível:

\title{
(...)
}

${ }^{226} \mathrm{O}$ juiz atua de forma indireta, pois não determina expressamente que o Poder Público deixará de realizar tal ou qual política pública para efetivar o direito fundamental social postulado em juízo, apenas ordenando a implantação da política postulada, cabendo ao órgão gestor financeiro proceder ao remanejamento de verbas.

${ }^{227}$ OLSEN, Ana Carolina Lopes. Op. cit., p. 288-289. 
Não deixo de conferir, no entanto, assentadas tais premissas, significativo relevo ao tema pertinente à 'reserva do possível' (Stephen Holmes/Cass Sunstein, The Cost of Rights, 1999, Norton, New York), notadamente em sede de efetivação e implementação (sempre onerosas) dos direitos de segunda geração (direitos econômicos, sociais e culturais), cujo adimplemento, pelo Poder Público, impõe e exige, deste, prestações estatais positivas concretizadoras de tais prerrogativas individuais e/ou coletivas.

É que a realização dos direitos econômicos, sociais e culturais - além de caracterizar-se pela gradualidade de seu processo de concretização - depende, em grande medida, de um inescapável vínculo financeiro subordinado às possibilidades orçamentárias do Estado, de tal modo que, comprovada, objetivamente, a incapacidade econômico-financeira da pessoa estatal, desta não se poderá razoavelmente exigir, considerada a limitação material referida, a imediata efetivação do comando fundado no texto da Carta Política.

Não se mostrará lícito, no entanto, ao Poder Público - em tal hipótese - mediante indevida manipulação de sua atividade financeira e/ou político-administrativa criar obstáculo artificial que revele o ilegítimo, arbitrário e censurável propósito de fraudar, de frustrar e de inviabilizar o estabelecimento e a preservação, em favor da pessoa e dos cidadãos, de condições materiais mínimas de existência. Cumpre advertir, desse modo, que a cláusula da 'reserva do possível' ressalvada a ocorrência de justo motivo objetivamente auferível - não pode ser invocada pelo Estado, com a finalidade de exonerar-se do cumprimento de suas obrigações constitucionais, notadamente quando, dessa conduta governamental negativa, puder resultar nulificação ou, até mesmo, aniquilação de direitos constitucionais impregnados de um sentido de essencial fundamentabilidade.

(...)

Vê-se, pois, que os condicionamentos impostos, pela cláusula da 'reserva do possível', ao processo de concretização dos direitos de segunda geração - de implantação sempre onerosa -, traduzem-se em um binômio que compreende, de um lado, (1) a razoabilidade da pretensão individual/social deduzida em face do Poder Público e, de outro, (2) a existência de disponibilidade financeira do Estado para tornar efetivas as prestações positivas dele reclamadas.

(...)

Não obstante a formulação e a execução de políticas públicas dependam de opções políticas a cargo daqueles que, por delegação popular, receberam investidura em mandato eletivo, cumpre reconhecer que não se revela absoluta, nesse domínio, a liberdade de conformação do legislador, nem a de atuação do Poder Executivo.

É que, se tais Poderes do Estado agirem de modo irrazoável ou procederem com a clara intenção de neutralizar, comprometendo-a, a eficácia dos direitos sociais, econômicos e culturais, afetando, como decorrência causal de uma injustificável inércia estatal ou de um abusivo comportamento governamental, aquele núcleo intangível consubstanciador de um conjunto irredutível de condições mínimas necessárias a uma existência digna, e essenciais à própria sobrevivência do indivíduo, aí, então, justificar-se-á, como precedentemente já enfatizado - e até mesmo por razões fundadas em um imperativo ético-jurídico -, a possibilidade de intervenção do Poder Judiciário, em ordem a viabilizar, a todos, o acesso aos bens cuja fruição lhes haja sido injustamente recusada pelo Estado.

Este precedente reconheceu de forma expressa a possibilidade de intervenção judicial para o fim de dar efetividade a um direito fundamental. Desta forma, o Judiciário não só tem competência para analisar a peça orçamentária, como também para determinar que se realizem as realocações que se fizerem necessárias, a fim de tornar concretos os desígnios constitucionais. 
Portanto, se a Lei Fundamental já inscreveu em seu texto os valores fundamentais da sociedade, transformando-os em direitos fundamentais, não resta outra alternativa ao administrador do dinheiro público que reservar o que for necessário para a sua efetivação, sob pena de fazê-lo mediante determinação judicial.

Ressalte-se que o entendimento aqui defendido não é unânime.

Com base na doutrina italiana, o Professor Fernando Facury Scaff afirma que tal decisão é denominada "sentença aditiva", assim entendida como "aquela que implica em aumento de custos para o Erário, obrigando-o ao reconhecimento de um direito social não previsto originalmente no orçamento do poder público demandado". ${ }^{228}$ Não obstante a previsão constitucional dos direitos sociais e a falta de credibilidade no Poder Legislativo, não vislumbra o Autor a possibilidade de o Poder Judiciário implementar políticas públicas, especialmente por duas razões: $(i)$ a decisão é pontual e atinge apenas uma pessoa ou um grupo de pessoas; (ii) o Judiciário não é responsável pela ordenação de despesas e não pode interferir no planejamento governamental exercido pelo Legislativo e pelo Executivo. Afirma que não se pode substituir a "discricionariedade do administrador" e a "discricionariedade do legislador" pela "discricionariedade do juiz" e apenas se mostra admissível a sentença aditiva desde que seus efeitos financeiros não sejam imediatos, possibilitando ao órgão responsável pela gestão dos recursos que proceda a devida destinação das verbas no orçamento seguinte, em cumprimento à ordem judicial.

Ora, impedir a efetivação dos direitos sociais por razões de ordem econômica - a já conhecida escassez de recursos - significa permitir que a Economia se sobreponha de forma absoluta ao Direito, que o discurso neoliberal de redução da intervenção estatal e diminuição dos gastos torne inócuo o rol de direitos arduamente conquistados e alçados a categoria de fundamentais em 5 de outubro de 1988 pela nova ordem constitucional.

Por mais que se pretenda alterar a configuração original da Constituição de 1988 (por meio de sucessivas emendas, como a EC 20/98 e EC 41/2003), o certo é que os direitos fundamentais sociais são protegidos por cláusulas pétreas ${ }^{229}$ e não podem ter seu conteúdo esvaziado pelo legislador do futuro.

E se ao Judiciário, como Poder de Estado que é, cabe alguma função, ela não pode ser outra que não a defesa da ordem jurídica. Portanto, argumentos de ordem econômica podem e devem ser considerados, mas a preocupação do órgão julgador não deve ser

\footnotetext{
${ }^{228}$ SCAFF, Fernando Facury. Sentenças aditivas, direitos sociais e reserva do possível. In SARLET, Ingo Wolfang; TIMM, Luciano Benetti (orgs.). Op. cit., p. 149.

${ }^{229}$ Confira-se artigo 60, $\S 4^{\circ}$, da CFR.
} 
unicamente a de buscar o equilíbrio fiscal, e sim a de fazer valer os direitos e garantias fundamentais.

Bastante elucidativa e em consonância com o ponto de vista aqui defendido é a decisão proferida no Incidente de Uniformização de Jurisprudência (Processo $\mathrm{n}^{\mathbf{o}}$ 2003.72.04004939-1), em 25/06/2004, pela 1ª Turma Recursal do Rio Grande do Sul, cujo objeto versava em estabelecer qual a renda limite a ser considerada para a aplicação do artigo 13 da Emenda Constitucional $n^{\text {o }}$ 20/98, a do recluso ou a de seus dependentes. ${ }^{230}$ Nas palavras do Relator, o Juiz Federal Roger Raupp Rios:

(...) Por fim, da leitura do incidente de uniformização pode-se extrair também a preocupação do INSS com o incremento no número de benefícios em virtude da adoção da interpretação impugnada. Esta preocupação não pode ser erigida a princípio de interpretação constitucional. Ela diz respeito, na verdade, à chamada cláusula da reserva do possível nos direitos fundamentais sociais, entendida como limitação fática à eficácia da norma de direito fundamental prestacional, tendo que o conceito de norma constitucional tipo princípio é a de mandamento jurídico constitucional de realização de algo na maior medida do possível, dentro das possibilidades fáticas e jurídicas (ver Robert Alexy, Teoría de los derechos fundamentales, trad. Ernesto G. Valdez, Madrid: Centro de Estudios Constitucionales, 1993). A reserva do possível não é um princípio de interpretação constitucional e não pode com isto ser confundida. Uma coisa é dizer que os direitos sociais não podem, faticamente, ir além das possibilidades econômicas. Outra, bem diferente, é colocar a restrição como princípio de interpretação, buscando o equacionamento, prévio e abstrato, de quaisquer questões de interpretação constitucional. A reserva do possível é um argumento fático que pode ser contraposto, acaso devidamente comprovado (o que nem de longe ocorreu neste feito), no juízo constitucional de concordância prática, informado pela proporcionalidade. A reserva do possível é um limite fático ponderável na concretização da norma tipoprincípio, não um a priori lógico ou normativo, muito menos um princípio hermenêutico. É preciso que se sublinhe esse ponto, sob pena de a própria ordem jurídica como um todo, especialmente a constitucional, ser suplantada por motivações da ideologia econômica hoje hegemônica (uma espécie de "fundamentalismo econômico neoliberal")." - grifo meu.

No mesmo sentido são as conclusões alcançadas por Ricardo Pires Calciolari ao analisar, de forma crítica, o sentido que tem sido dado à reserva do possível no Brasil:

E mais; tem-se alçado a reserva do possível ao grau de princípio, o que, ao nosso entender, é um completo absurdo, pois não se pode dar característica normativodeontológica a uma construção doutrinária sem o respectivo arcabouço normativo.

${ }^{230}$ A Emenda Constitucional $n^{\circ}$ 20/98, em seu artigo 13, determinou que o salário-família e o auxílioreclusão serão concedidos àqueles que tenham renda bruta mensal igual ou inferior a $\mathrm{R} \$ 360,00$ (trezentos e sessenta reais). Após sua promulgação, dúvidas surgiram acerca do titular da renda a ser considerada, vale dizer, do segurado ou dos seus dependentes, ensejando a propositura de ações judiciais visando esclarecer a questão. No julgamento mencionado, a Turma Recursal do Rio Grande do Sul concluiu que era a renda dos dependentes que deveria ser considerada para fins de concessão do benefício. Não obstante, em sede de Repercussão Geral, o Supremo Tribunal Federal firmou entendimento contrário. 
É claro, e não podemos deixar de frisar, que ninguém é obrigado ao impossível. A máxima já consagrada no clássico brocardo latino ad impossibilia nemo tenetur (ninguém pode ser obrigado a fazer o impossível) a nosso ver, para além de princípio, é imperativo fático excludente de qualquer obrigação. Todavia, não basta a mera argumentação; é preciso comprovação dessa impossibilidade fática, como bem asseverou Celso de Mello. Do contrário, corremos o risco de ver perecer não só os direitos sociais mas também os individuais, já que estes últimos requerem também prestações públicas para sua efetividade.

Assim, igualmente argumento de que o Judiciário interfere na esfera de competência dos outros Poderes quando prolata decisões que têm impacto orçamentário não merece acolhida. Essa aparente interferência é, a bem da verdade, cumprimento de função constitucional dada ao Judiciário que deve proteger a Carta Magna e zelar pela sua efetividade, como já pontuamos no Capítulo 1. Apenas ad argumentandum, esclarecemos que, para os que não se convencem com os argumentos postos, os gastos com cumprimento de sentença e decisões judiciais condenatórias contra a União em matéria previdenciária, assistencial e de saúde pública são irrisórios quando comparados às quantias desvinculadas do orçamento da Seguridade Social, como tivemos a oportunidade de demonstrar em gráfico sobre despesas do ano de 2008, nesse capítulo.

Temos como claro que, em matéria de direitos sociais, o argumento da reserva do possível não deve prevalecer na situação atual. Inviável a argumentação da impossibilidade fática em realizar os imperativos constitucionais sociais diante da situação claramente superavitária do orçamento da Seguridade Social. ${ }^{231}$

\subsection{Políticas públicas e ações coletivas}

O sistema processual brasileiro possibilita que a defesa dos direitos seja veiculada por meio de ações individuais ou de ações coletivas.

Nossa tradição jurídica, inspirada no modelo liberal, prestigia o ajuizamento de ações individuais, não obstante os estudiosos das políticas públicas defendam que as ações coletivas são mais adequadas a tal fim ${ }^{232}$, pelo menos por três razões:

a) É de interesse de toda a coletividade que todos aqueles que se encontram na mesma situação recebam o mesmo tratamento dos Poderes Públicos;

\footnotetext{
${ }^{231}$ CALCIOLARI, Ricardo Pires. Op. cit., 2009, p. 173.

${ }^{232}$ Segundo Alfredo Buzaid, "o último quartel deste século assiste a uma profunda transformação da sociedade, debilitando-se cada vez mais a concepção individualista do direito, que vai cedendo lugar a uma concepção social, com o triunfo da política de massa, dominante no mundo contemporâneo. Entra, no conjunto, um elemento, que sempre existiu, mas que só agora começa a adquirir realce: o povo. Dos direitos reconhecidos em favor do povo, muitos foram incorporados em normas constitucionais e outros figuram na legislação ordinária. Há o direito à vida, à saúde, ao trabalho, ao bem-estar, à educação, ao meio ambiente e à segurança, que tem uma conotação social, sendo atualmente designados por direito coletivo. A preocupação do legislador moderno foi não só de reconhecer plenamente esses direitos, como também de dotá-los de instrumentos aptos à sua proteção, não se contentando com atribuí-los a um determinado órgão, como o Ministério Público, mas disseminando-os às pessoas, às classes e às categorias profissionais, em favor das quais conferiu legitimidade para estarem em juízo defendendo em nome próprio direito alheio. Esta é, a nosso ver, a corajosa revolução, que mudou os quadros do direito tradicional e introduziu nova nomenclatura à tutela dos direitos coletivos" (grifos do Autor) (BUZAID, Alfredo. Considerações sobre o mandado de segurança coletivo. São Paulo: Saraiva, 1992. p. 13-14).
} 
b) A resolução de conflitos individuais por meio de ações coletivas reduz significativamente o número de ações individuais, pois uma única decisão judicial tem o condão de abarcar inúmeros interessados que se encontram na mesma situação jurídica;

c) As ações coletivas são, nas palavras de Rodolfo de Camargo Mancuso, instrumento

de uma legítima participação, respaldada pelo lídimo direito que a cada cidadão assiste de ter não apenas uma vida, mas 'qualidade de vida'; não qualquer administração, mas aquela proba e eficaz. Deveria o Estado-Administração, assim, ficar reconhecido ao cidadão, quando este, exercendo um seu direito subjetivo público, lhe indique, via jurisdicional, a omissão que urge ser suprida, a ação que o interesse público impõe seja praticada ou a irregularidade que deve ser corrigida. (grifos do Autor). ${ }^{233}$

A eminente jurista Ada Pellegrini Grinover expressa com maestria este avanço, sob a ótica do jurisdicionado e sob a ótica do Judiciário:

Também o Poder Judiciário foi beneficiado pelos processos coletivos, em termos de projeção e racionalização do trabalho. A sobrecarga dos tribunais e a sensação de inutilidade das decisões individualizadas eram agravadas pela frequente contradição dos julgados e pela demora na solução das controvérsias. A finalidade social da função jurisdicional, que é de pacificar com justiça, perdia-se diante da fragmentação e pulverização dos conflitos, sempre tratados a título individual. A substituição de decisões atomizadas (na expressão de Kazuo Watanabe) pelo tratamento molecular das controvérsias, levando à solução do Judiciário, de uma só vez, conflitos que envolvem milhares ou milhões de pessoas, significou tornar o juiz a peça principal na condução de processos de massa que, por envolverem conflitos de massa, têm sempre relevância política e social. Graças aos processos coletivos, o Judiciário, saindo de uma posição frequentemente distante e remota, tornou-se protagonista das grandes controvérsias nacionais. ${ }^{234}$

Destaca-se, nesta toada, a importância da atuação do Ministério Público que, por expressa determinação constitucional,

pode negociar em patamar de igualdade com a Administração ou com os Entes Privados - que eventualmente prestam serviços públicos ou têm obrigação de atender determinada política pública -, e agir em Juízo, ultrapassando os obstáculos existentes (como custas, honorários advocatícios, preparo técnico para deduzir e defender o direito desrespeitado), o que muito dificilmente ocorre com entidades da Sociedade Civil organizada, em especial aquelas dedicadas à defesa dos direitos sociais. ${ }^{235}$

233 MANCUSO, Rodolfo de Camargo. Ação Civil Pública: Instrumento de participação na tutela do bem comum. In Participação e Processo, 2007b, p. 197.

${ }^{234}$ GRINOVER, Ada Pellegrini. A marcha do processo. Rio de Janeiro: Forense Universitária, 2000. p. 2526.

${ }^{235}$ FRISCHEISEN, Luiza Cristina Fonseca. Políticas públicas: a responsabilidade do administrador e o Ministério Público. São Paulo: Max Limonad, 2000. p. 113. 
Infelizmente, passados mais de 20 (vinte) anos da edição da Lei $n^{\circ} 7.347 / 85$ e da Constituição de 1988, ainda é muito tímida a utilização das ações coletivas para a defesa dos direitos fundamentais sociais, como também o Judiciário tem demonstrado muita cautela no manejo dos poderes que lhe foram conferidos na sua condução.

Como observa a Professora Ada Grinover, não há como negar que

\begin{abstract}
é muito mais fácil julgar uma causa individual pautada no direito positivo tradicional do que uma lide coletiva. Esta, não raro, envolve áreas do conhecimento estranhas à ciência jurídica, visto que a transdisciplinaridade é uma das mais marcantes características da tutela jurisdicional coletiva, ou põe em xeque a clássica divisão dos poderes quando se questiona em juízo a adequação de uma determinada política pública à Constituição ou o desatendimento de direitos sociais legalmente previstos. Não obstante, ainda é a regra que a análise do trabalho de um magistrado seja medida pelo número de processos julgados e não pela relevância social deles. Ainda vale mais julgar dez causas iguais que uma coletiva, mesmo que esta solucione a lide daquelas dez e de dezenas de outras, futuras e idênticas. ${ }^{236}$
\end{abstract}

As vantagens das ações coletivas são evidentes, em todas as causas envolvendo direitos difusos, coletivos e individuais homogêneos. No entanto, a decisão judicial ali proferida, por mais abrangente, não tem o condão de criar diretamente uma política pública, quando muito influencia os Poderes responsáveis pela sua elaboração nos casos futuros. O Poder Judiciário apenas afasta as ilegalidades e inconstitucionalidades constatadas na política, adequando-a aos comandos legais, sem desbordar dos limites de sua competência.

Traçadas as balizas que devem orientar a atuação judicial no controle das políticas públicas, a tarefa a seguir, objeto do Capítulo 3, é analisar como o Poder Judiciário vem decidindo as questões envolvendo as políticas públicas previdenciárias, identificando, nos casos selecionados, os critérios utilizados nos julgamentos, inclusive nos casos de ações coletivas.

${ }^{236}$ GRINOVER, Ada Pellegrini. Garantia de acesso à justiça com efetividade. In MILARÉ, Édis (coord.). A ação civil pública após 20 anos: efetividade e desafios. São Paulo: Revista dos Tribunais, 2005. p. 31. 


\title{
O CONTROLE JUDICIAL DAS POLÍTICAS PÚBLICAS PREVIDENCIÁRIAS
}

\begin{abstract}
Estabelecidos os contornos do direito fundamental à previdência social, as diretrizes impostas (política de Estado) na formulação das políticas de Governo, de um lado, e o âmbito de atuação judicial no seu controle, de outro, cumpre-nos agora analisar como esta interação tem ocorrido na prática.

Foram selecionadas decisões judiciais que demonstram como o Poder Judiciário tem se manifestado quando instado a se pronunciar sobre o direito fundamental em questão, quer para dizer sobre a constitucionalidade ou legalidade de um ato normativo, quer para dizer sobre a competência do órgão judicial em casos de omissão do Poder competente.

A partir desta análise de casos, buscaremos identificar se existe um alinhamento ideológico entre os Poderes, tarefa um tanto quanto inglória, especialmente em face do modelo de controle judicial adotado pelo sistema brasileiro, que permite a declaração de inconstitucionalidade por qualquer juiz no caso concreto, o que está longe de significar que seu entendimento reflete o dos demais.
\end{abstract}

\subsection{Análise de casos}

\subsubsection{Valor do benefício: cálculo da renda mensal inicial}

O artigo 202 da Constituição Federal, em sua redação originária, estabeleceu novo critério de cálculo da renda mensal inicial dos benefícios, de forma que corresponda à média dos trinta e seis últimos salários de contribuição, corrigidos monetariamente mês a mês.

O dispositivo apenas foi regulamentado quase três anos depois, com a edição da Lei $\mathrm{n}^{\mathrm{o}} 8.213 / 91$.

A maior controvérsia decorrente da alteração girou em torno da legislação aplicável aos benefícios concedidos no período compreendido entre 05/10/1988 e 05/04/1991 (termo 
final fixado pelo artigo 59 do ADCT para a edição da Lei de Benefícios), já que o artigo 144 da Lei $n^{\circ} 8.213 / 91$, embora tenha determinado a revisão dos benefícios concedidos neste período, fixou seu termo inicial em junho de 1992, vedando o pagamento de quaisquer diferenças anteriores.

Após muito embate, o Supremo Tribunal Federal firmou o entendimento de que o artigo 202 não era autoaplicável, como demonstram as seguintes ementas:

\footnotetext{
"EMENTA: Previdência Social.

Ora, esta Primeira Turma, ao julgar os ERE 153.655, relator o Sr. Ministro SYDNEY SANCHES, já decidiu que o disposto no artigo 202 da Carta Magna sobre o cálculo da aposentadoria não é autoaplicável, por depender de legislação que posteriormente entrou em vigor (Leis 8.212. e 8.213, ambas de 24.07.91). Portanto, a esse propósito, e até a entrada em vigor da legislação acima referida, continuaram vigentes as normas editadas anteriormente à atual Carta Magna, razão por que foi correto o cálculo feito pelo recorrente quanto ao valor do benefício, que também levou em conta a atualização monetária das contribuições consideradas para esse cálculo, segundo aquelas normas, não se desrespeitando assim o princípio - reafirmado no artigo $201, \S 3^{\circ}$, da atual Constituição - de que todos os salários de contribuição considerados no cálculo do benefício serão corrigidos monetariamente.

Dessa orientação discrepou o acórdão recorrido.

Recurso extraordinário conhecido e provido."

(STF, RE 157.042, Relator Ministro Moreira Alves, DJ 19/04/96).
}

Também o Supremo Tribunal Federal concluiu pela constitucionalidade da limitação imposta pelo parágrafo único do artigo 144 da Lei nº 8.213/91, verbis:

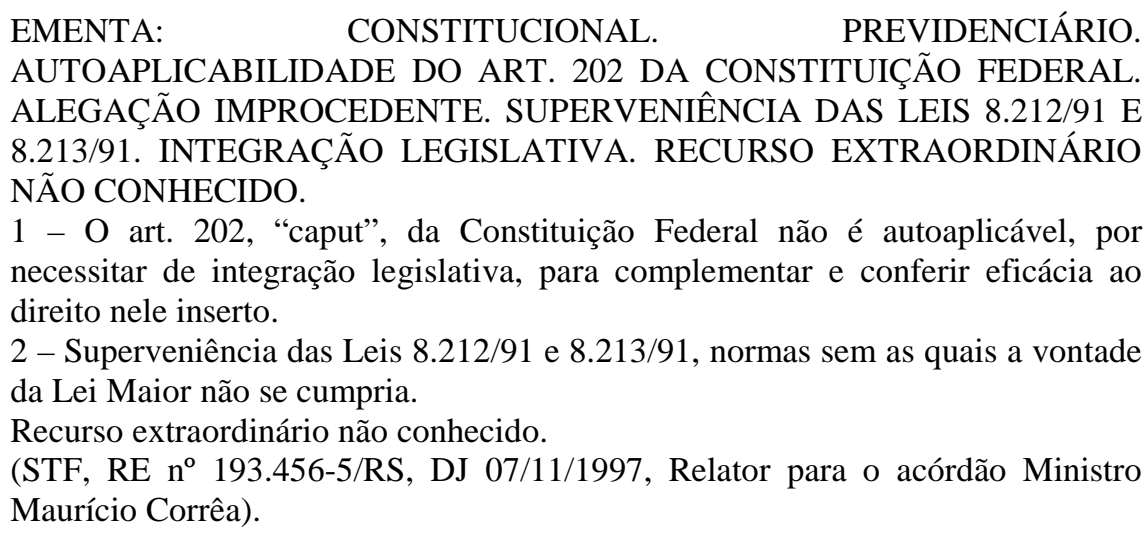

A norma inscrita no artigo 202 não integra o conteúdo do direito fundamental à previdência social na medida em que cuida de fórmula de cálculo, matéria que, no nosso entender, não deve constar de texto constitucional.

O $\S 3^{\circ}$ do artigo 201 da Constituição assegura a correção de todos os salários de contribuição considerados no cálculo do benefício, norma que efetivamente nos diz como 
deve ser realizado o direito à previdência em relação ao cálculo inicial do benefício e que já é suficiente para a sua salvaguarda.

No entanto, tanto uma como a outra não são imediatamente aplicáveis, na medida em que não estabelecem os índices de correção a serem aplicados, ensejando a sua complementação pelo legislador ordinário. Por tal razão, consideramos correta a interpretação dada pela Corte Suprema quanto aos seus efeitos.

O mesmo não é possível dizer em relação à limitação dos efeitos da revisão determinada pelo artigo 144 da Lei no 8.213/91.

Não há amparo para o tratamento diferenciado outorgado aos segurados que tiveram seus benefícios concedidos no período de 05/10/88 a 05/04/91 e aqueles que o receberam a partir daí, valendo-se apenas e tão somente do discrimen data (antes e depois de 05/04/1991), como se os segurados pudessem escolher a data em que ficariam doentes, a data em que implementariam o requisito etário, a data do seu óbito, etc., etc.

Concordamos, aqui, com os fundamentos invocados pelo então Relator Marco Aurélio, que restou vencido, apontando a inconstitucionalidade da restrição imposta pelo artigo 144, verbis:

\footnotetext{
(...) A Constituição Federal de 1988 previu, de forma clara e precisa, a atualização dos salários de contribuição, afastando, assim, verdadeiro enriquecimento sem causa. Explico: na vigência da ordem jurídica anterior o futuro beneficiário da Previdência Social contribuía a partir da moeda atualizada. Quando verificada a oportunidade de contraprestação pelo Instituto este a honrava de forma defasada, ou seja, procedendo ao cálculo do benefício a partir não do valor representado à época do recolhimento pelo salário de contribuição, mas a partir do valor nominal deste último em que pese a passagem de até doze meses.

Atente-se para o esdrúxulo quadro suscitado pelo afastamento de efeitos financeiros no período de outubro de 1988 a maio de 1992. Por força do disposto no artigo 58 do ADCT, os benefícios então mantidos pela previdência social, tiveram os valores revistos, sendo restabelecido o poder aquisitivo expresso em número de salários mínimos na época da concessão.

(...)

Pois bem, surge, então, o seguinte resultado. Benefício alcançado até 5 de outubro de 1988 tornou-se passível de atuação por força do citado artigo 58. Os deferidos após tal data e até 5 de abril de 1991, período fixado pelo caput do artigo 144 em análise, não o serão.

O conflito exegético salta aos olhos, não merecendo, assim frutificar.
}

Concluímos, assim, que o Supremo Tribunal Federal não feriu o conteúdo do direito fundamental à previdência social ao dizer que o artigo 202 da Constituição Federal não é autoaplicável, reconhecendo a competência do Poder Legislativo para disciplinar a matéria, seguindo os contornos estabelecidos pelo texto constitucional (correção de todos os salários de contribuição), estes sim integrantes do direito fundamental. 
No entanto, ao considerar constitucional a limitação imposta pelo artigo 144 da Lei $\mathrm{n}^{\circ} 8.213 / 91$, tratou de forma diferenciada segurados que se encontram na mesma condição, sem qualquer justificativa lógico-racional a autorizar a discriminação.

\subsubsection{Fator previdenciário}

A Emenda Constitucional n 20/1998 alterou substancialmente a redação originária do artigo 202 da Constituição Federal. O dispositivo reformado, atualmente em vigor, apenas trata do sistema de previdência privada.

Foi desconstitucionalizada a norma que determinava a correção dos 36 (trinta e seis) últimos salários de contribuição, supressão que não deveria trazer qualquer prejuízo ao segurado, na medida em que permaneceu inatacável a garantia inscrita no $\S 3^{\circ}$ do artigo 201, que assegura a correção de todos os salários de contribuição considerados no cálculo do benefício.

Foi então editada, em 26/11/1999, a Lei no 9.876, dando nova redação ao artigo 29 e $\S$, dos quais se destacam:

Art. 29. O salário de benefício consiste:

I - para os benefícios de que tratam as alíneas $b$ e $c$ do inciso I do art. 18, na média aritmética simples dos maiores salários de contribuição correspondentes a oitenta por cento de todo o período contributivo, multiplicada pelo fator previdenciário;

II - para os benefícios de que tratam as alíneas $a, d$, e e $h$ do inciso I do art. 18, na média aritmética simples dos maiores salários de contribuição correspondentes a oitenta por cento de todo o período contributivo.

(...)

$\S 7^{\circ} \mathrm{O}$ fator previdenciário será calculado considerando-se a idade, a expectativa de sobrevida e o tempo de contribuição do segurado ao se aposentar, segundo a fórmula constante do Anexo a esta Lei.

$\S 8^{\circ}$ Para efeito do disposto no parágrafo anterior, a expectativa de sobrevida do segurado na idade da aposentadoria será obtida a partir da tábua completa de mortalidade construída pelo Instituto Brasileiro de Geografia e Estatística, considerando-se a média nacional única para ambos os sexos.

$\S 9^{\circ}$ Para efeito da aplicação do fator previdenciário ao tempo de contribuição do segurado serão adicionados:

I - cinco anos, quando se tratar de mulher; ou

II - cinco anos, quando se tratar de professor que comprove exclusivamente tempo de efetivo exercício das funções de magistério na educação infantil e no ensino fundamental e médio;

III - dez anos, quando se tratar de professora que comprove exclusivamente tempo de efetivo exercício das funções de magistério na educação infantil e no ensino fundamental e médio.

O Anexo da Lei $n^{\circ} 8.213 / 91$, referido no $\S 7^{\circ}$, estabeleceu a fórmula do fator previdenciário: 
$\left.f=\frac{T c \times a}{E s} \times\left[1+\frac{(I d+T c \times a}{I d}\right)\right]$

( $\mathrm{f}=$ fator previdenciário; Es = expectativa de sobrevida no momento da aposentadoria; $\mathrm{Tc}=$ tempo de contribuição até $\mathrm{o}$ momento da aposentadoria; Id = idade no momento da aposentadoria; $\mathrm{a}=$ alíquota de contribuição correspondente a 0,31 )

O fator previdenciário foi introduzido pela Lei $\mathrm{n}^{\circ}$ 9.876/99 como o novo critério de cálculo do salário de benefício.

Guardando coerência com o que afirmamos anteriormente, a matéria deve ser disciplinada efetivamente por lei ordinária, possibilitando o constante aperfeiçoamento do sistema previdenciário e a apuração de benefícios cujos valores se aproximem, o máximo possível, do salário percebido pelo segurado quando em atividade.

Esta afirmação está longe de defender que ao legislador ordinário é outorgado um verdadeiro cheque em branco, a ser preenchido ao seu bel-prazer. Sua margem de discricionariedade é mínima, vez que todos os seus contornos já estão previamente estabelecidos.

Com isso queremos dizer que o novo critério de cálculo criado pela Lei $n^{\circ}$ 9.876/99 é inconstitucional por trazer em sua fórmula um componente redutor não amparado pela Lei Maior, qual seja a idade.

O fator previdenciário desestimula, às escâncaras, as aposentadorias precoces, pois reduz significativamente o valor do benefício aos segurados que optam por parar de trabalhar mais cedo, não obstante tenham cumprido a carência exigida.

Não se retira do órgão político competente para a formulação das políticas públicas previdenciárias a opção em estimular a permanência dos trabalhadores na ativa. No entanto, os desestímulos à aposentação não podem embutir limitações ao direito fundamental não acobertadas pelo texto constitucional.

De acordo com a Constituição Federal de 1988, a idade é fator a ser considerado apenas na concessão do benefício de aposentadoria por idade, não podendo ser utilizada como um dos componentes do cálculo de qualquer benefício (inclusive dela mesma), como quer a Lei $n^{\circ} 9.876 / 99$. 
A bem da verdade, o que pretendeu o legislador foi "consertar" o erro ocorrido quando da aprovação da Emenda Constitucional no 20/1998 que, ao extinguir a aposentadoria por tempo de serviço proporcional, criou regra de transição aplicável aos segurados que já eram filiados ao Regime Geral em 16/12/1998, mas ainda não haviam cumprido todos os requisitos para se aposentar. A norma transitória possibilitou a concessão do benefício a tais segurados desde que cumprissem um tempo de serviço adicional (denominado "pedágio”) e preenchessem o requisito etário.

Só que, por um "cochilo" do legislador reformador, aos segurados que ingressassem no sistema após 16/12/1998 seria concedida aposentadoria por tempo de contribuição integral se comprovada a carência de 180 (cento e oitenta) contribuições, independentemente da idade.

Desta forma, a Emenda 20 conseguiu criar uma regra de transição (que em princípio deveria ser mais benéfica) mais rígida do que a nova regra, exigindo a comprovação de idade mínima para a concessão de aposentadoria proporcional e não o fazendo para os casos de aposentadoria integral.

A ocasião ideal (denominada pelos cientistas políticos como "janela de oportunidade") para a exigência do requisito etário nos casos de aposentadoria por tempo de contribuição, aplicável aos segurados que ingressassem no sistema a partir de 16/12/1998, era a Emenda Constitucional, instrumento legal adequado para a alteração pretendida. No entanto, perdeu-se a oportunidade e a forma encontrada para corrigir a omissão foi a introdução do requisito etário como um dos componentes do fator previdenciário.

Na avaliação de Marcus André de Melo,

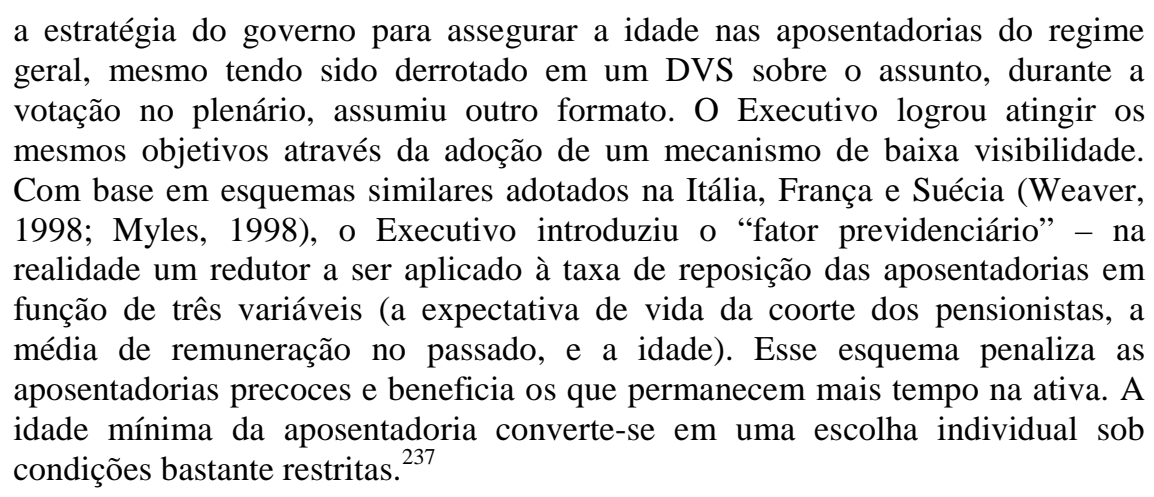

${ }^{237}$ MELO, Marcus André. Op. cit., 2002, p. 133. 
O fator previdenciário teve sua inconstitucionalidade suscitada nas ADINs ns. 2.110-9/DF e 2.111-7/DF, propostas pelo Partido Comunista do Brasil (PC do B).

O Supremo Tribunal Federal reconheceu a constitucionalidade do fator previdenciário, cuja ementa transcrevemos parcialmente, refletindo com bastante clareza os argumentos utilizados pelo Eminente Relator, o Ministro Sidney Sanches, verbis:

(...) No que tange ao montante do benefício, ou seja, quanto aos proventos da aposentadoria, propriamente ditos, a Constituição Federal de 5.10.1988, em seu texto originário, dele cuidava no art. 202.

O texto atual da Constituição, porém, com o advento da E.C. no 20/98, já não trata dessa matéria, que, assim, fica remetida "aos termos da lei", a que se referem o 'caput' e o $\S 7^{\circ}$ do novo art. 201.

Ora, se a Constituição, em seu texto em vigor, já não trata do cálculo do montante do benefício da aposentadoria, ou melhor, dos respectivos proventos, não pode ter sido violada pelo art. $2^{\circ}$ da Lei $\mathrm{n}^{\circ}$ 9.876, de 26.11.1999, que, dando nova redação ao art. 29 da Lei $\mathrm{n}^{\circ}$ 8.213/91, cuidou exatamente disso. E em cumprimento, aliás, ao 'caput' e ao parágrafo $7^{\circ}$ do novo art. 201.

2. Aliás, com essa nova redação, não deixaram de ser adotados, na Lei, critérios destinados a preservar o equilíbrio financeiro e atuarial, como determinado no 'caput' do novo art. 201.

O equilíbrio financeiro é o previsto no orçamento geral da União.

E o equilíbrio atuarial foi buscado, pela Lei, com critérios relacionados com a expectativa de sobrevida no momento da aposentadoria, com o tempo de contribuição e com a idade, até esse momento, e, ainda, com a alíquota de contribuição correspondente a $0,31 .(\ldots)^{238}$

Maior destaque deve ser dado à Declaração de Voto apresentada pelo Ministro Nelson Jobim, adentrando com profundidade na análise do fator previdenciário, com o intuito de demonstrar sua constitucionalidade. Sob o ponto de vista econômico, ressalte-se.

Vejamos alguns trechos importantes:

(...)

Em relação a essa questão do fator atuarial, convenci-me de que a fórmula estabelecida na lei através desses cálculos passo a passo, estabelecendo a correção monetária de todas as contribuições - a média aritmética simples das $80 \%$ maiores contribuições, aplicando-lhes o fator previdenciário -, é exatamente o critério para a busca de um mínimo equilíbrio atuarial não ortodoxo, pois não corresponde ao valor da capitalização da contribuição, mas ao cálculo que leva em conta o tempo de contribuição, o percentual, a idade do trabalhador no momento da aposentadoria e, por último, o cálculo relativo à expectativa de vida do cidadão.

Essa é a única forma possível de se buscar um equilíbrio atuarial dentro do sistema. Não vejo lesão constitucional. Poderá haver, nitidamente, divergência sobre qual seria a melhor forma de calcular atuarialmente, mas essa opção cabe ao legislador.

Não nos cabe apurar, através da fixação da Constituição, qual a melhor fórmula, salvo, evidentemente, se estivéssemos perante uma fórmula totalmente abusiva e não razoável. E aqui há um índice de razoabilidade imenso no sentido de se estabelecer minimamente, na busca da justiça social, uma relação entre

${ }^{238}$ Publicada no DJ 05/12/2003. 
contribuição e expectativa de vida, de forma que aqueles que contribuírem durante um período de tempo maior compensem as aposentadorias precoces, que inviabilizam o processo de justiça social referido.

(...)

Sr. Presidente, para encerrar, nessa parte, acompanho o Sr. Relator. Porém, ele sustentou pelo menos um motivo para não acompanhar, dizendo simplesmente que a Constituição Federal, com a reforma da Emenda Constitucional no 20, não previu nenhuma forma de cálculo.

Acompanho integralmente o Relator.

Espero ter sustentado, também, que é absolutamente razoável, observados os princípios estabelecidos do equilíbrio atuarial e financeiro e, também, das obrigações correspondentes.

É como voto nessa parte, indeferindo.

Ao expor seu voto, o Ministro Nelson Jobim foi diretamente confrontado pelo Ministro Marco Aurélio, que também apresentou Declaração de Voto, no que restou vencido, apontando as razões que o levam a concluir pela inconstitucionalidade do fator previdenciário, verbis:

(...) Para mim é sinonímia: fator previdenciário ou fator idade são a mesma coisa, porque, em última análise, tomou-se o elemento idade para nortear-se os proventos da aposentadoria - isso ninguém pode negar. Senão vamos afastar daquela equação alfabética, que resulta em uma certa quantia, o item alusivo à idade. A idade norteia a época e os proventos da inatividade.

(...)

Digo que fator idade e fator previdenciário significam a mesma coisa porque a idade repercute no cálculo do benefício e, daí, entre as siglas da equação para chegar-se ao valor do benefício, tem-se a idade no momento da aposentadoria. Ao lado dessa idade, parte-se para o que se denominou "expectativa de sobrevida no momento da aposentadoria". Então, não há a menor dúvida de que se emprestou o rótulo ao novo trato da matéria, o rótulo fator previdenciário, que pode ser entendido às claras, com uma transparência maior, como o fator idade. Precisamos perquirir se esse discrimen é harmônico com a própria Constituição Federal; se o discrimen até mesmo é razoável, à luz do que normalmente acontece e dadas outras exigências para se ter a aposentadoria, estas sim previstas na Constituição Federal.

Se formos ao artigo 201 da Carta da República, na redação decorrente da Emenda Constitucional $n^{\circ} 20$, veremos que esse artigo 201, $\S 7^{\circ}$, incisos I e II, estabelece certas condições constitucionais para chegar-se à aposentadoria. No tocante à idade, a previsão ficou limitada à aposentadoria por idade propriamente dita. Não se estendeu esse elemento à aposentadoria que antes era por tempo de serviço e que a Emenda Constitucional $n^{\circ} 20$ transformou em aposentadoria por tempo de contribuição.

Há mais, e aí precisamos perceber o alcance dos diversos dispositivos constitucionais a partir de princípios que devem e precisam nortear a sua leitura, compreendendo-se até mesmo que, como lecionado pelo Professor Inocêncio Mártires Coelho, não temos, em um sistema, normas incompatíveis. A Constituição Federal é um grande todo e não podemos raciocinar, relativamente a um certo instituto, à margem dos princípios nela contidos. (...)

Com a máxima vênia ao entendimento majoritário da mais alta Corte de Justiça, entendemos que as razões invocadas para o reconhecimento da constitucionalidade do fator 
previdenciário destroem, em boa parte, o conteúdo do direito fundamental à previdência social.

Não foi mantida a unidade da Constituição, na medida em que se desconsiderou que: $(i)$ o requisito etário apenas é exigido na concessão do benefício de aposentadoria por idade, sendo indevida sua inclusão no cálculo do benefício com o intuito de postergar, tanto quanto possível, a inatividade; (ii) os benefícios previdenciários são custeados por contribuições específicas que, salvo efetiva comprovação em contrário, são suficientes para arcar com as despesas do sistema.

Também importa em retrocesso social por desestimular, de forma sorrateira, o exercício do direito ao benefício. Se o fizesse mediante estímulos construtivos, como a ampliação do mercado de trabalho, o crescimento da economia, o aumento dos salários e da qualificação dos trabalhadores, entre outros, problema algum teria. No entanto, desestimula o segurado mas não lhe oferece nada em troca.

O pior. Os dados embutidos na forma de cálculo são camuflados, criando-se uma operação matemática absolutamente ininteligível para a maior parte dos segurados da Previdência Social. Ou seja: além de o valor da renda mensal inicial em muito se distanciar do valor das contribuições pagas pelo segurado quando em atividade, dificulta-se a defesa do direito por tornar nebuloso o cálculo.

A suposta eficiência econômica da medida não se sustenta diante de tanta afronta aos postulados constitucionais, especialmente ao postulado fundante do Estado democrático brasileiro: a dignidade humana.

\subsubsection{Beneficiários: companheiros homossexuais}

Os beneficiários da Previdência Social são os segurados e os dependentes. Os dependentes se vinculam ao sistema de forma indireta, em decorrência da relação jurídica existente entre o segurado e a Previdência Social. Estão indicados no artigo 16 da Lei ${ }^{\circ}$ 8.213/91 e divididos nas seguintes classes:

I - o cônjuge, a companheira, o companheiro e o filho não emancipado, de qualquer condição, menor de vinte e um anos ou inválido; ${ }^{239}$

II - os pais;

III - o irmão não emancipado, de qualquer condição, menor de vinte e um anos ou inválido. ${ }^{240}$

239 A redação original do inciso I não exigia que o filho não fosse emancipado, sendo alterada pela Lei $n^{\circ}$ 9.032/95. 
$\S 1^{\circ}$ A existência de dependente de qualquer das classes deste artigo exclui do direito às prestações os das classes seguintes.

$\S 2^{\circ} \mathrm{O}$ enteado e o menor tutelado equiparam-se a filho mediante declaração do segurado e desde que comprovada a dependência econômica na forma estabelecida no Regulamento (redação dada pela Lei $n^{\circ}$ 9.528/97).

$\S 3^{\circ}$ Considera-se companheira ou companheiro a pessoa que, sem ser casada, mantém união estável com o segurado ou com a segurada, de acordo com $\S 3^{\circ}$ do artigo 226 da Constituição Federal.

$\S 4^{\circ}$ A dependência econômica das pessoas indicadas no inciso I é presumida e a das demais deve ser comprovada.

Em sua redação originária, a Lei nº 8.213/91 também considerava dependente do segurado, na última classe, a pessoa designada, menor de vinte e um anos ou maior de sessenta anos ou inválida. O inciso IV foi revogado pela Lei $n^{\circ}$ 9.032/95.

Ao tratar do benefício pensão por morte, a Constituição Federal apenas mencionou que ele é devido em caso de morte do segurado (homem ou mulher), ao cônjuge ou companheiro e dependentes (artigo 201, V).

O benefício foi regulamentado pelos artigos 74 a 79 da Lei $n^{\circ}$ 8.213/91, considerando-se dependentes aqueles inscritos no artigo 16 acima transcrito.

Para a legislação previdenciária (artigo 16, § $3^{\circ}$ ), portanto, apenas é considerado beneficiário o companheiro (ou a companheira) que mantém união estável com a segurada (ou o segurado).

A regra legal é mais restritiva que a norma constitucional, vez que o inciso $\mathrm{V}$ do artigo 201 da Constituição Federal não exige a configuração de união estável para que se configure a relação de dependência, sendo possível o pagamento de pensão por morte a companheiro/companheira do mesmo sexo.

A interpretação sistemática e teleológica do texto constitucional nos leva a concluir que o beneficiário da pensão por morte não é só aquele que vive em união estável com o segurado, pois se a intenção do legislador constituinte fosse a de impor tal limitação, seria suficiente a menção ao artigo $226, \S 33^{\circ}{ }^{241}$ De mais a mais, o princípio da igualdade impossibilita que companheiros do mesmo sexo sejam tratados de forma discriminatória, apenas e tão somente em razão de suas preferências sexuais.

Os Tribunais têm afastado a restrição imposta pela política pública, ao fundamento de que não acobertada pelo texto constitucional e de que afronta o princípio da igualdade,

${ }^{240}$ Também neste caso a redação original do inciso III não exigia que o irmão não fosse emancipado, sendo alterado pela Lei $\mathrm{n}^{\circ}$ 9.032/95.

${ }^{241}$ De acordo com o dispositivo, "para efeito da proteção do Estado, é reconhecida a união estável entre o homem e a mulher como entidade familiar, devendo a lei facilitar sua conversão em casamento". 
tratando de forma diferenciada efetivos dependentes, apenas por conta de suas preferências sexuais.

No julgamento da Apelação Cível no 2000.71.07.00.009347-0, o Egrégio Tribunal Regional Federal da $4^{\text {a }}$ Região julgou procedente a Ação Civil Pública interposta pelo Ministério, reconhecendo o(a) companheiro(a) homossexual como um dos dependentes constitucionais do benefício pensão por morte, em acórdão assim ementado:

CONSTITUCIONAL. PREVIDENCIÁRIO. PROCESSO CIVIL. AÇÃO CIVIL PÚBLICA. CABIMENTO. MINISTÉRIO PÚBLICO. LEGITIMIDADE. ABRANGÊNCIA NACIONAL DA DECISÃO. HOMOSSEXUAIS. INSCRIÇÃO DE COMPANHEIROS COMO DEPENDENTES NO REGIME GERAL DE PREVIDÊNCIA SOCIAL.

(...)

1. O princípio da dignidade humana veicula parâmetros essenciais que devem ser necessariamente observados por todos os órgãos estatais em suas respectivas esferas de atuação, atuando como elemento estrutural dos próprios direitos fundamentais assegurados na Constituição.

2. A exclusão dos benefícios previdenciários, em razão da orientação sexual, além de discriminatória, retira da proteção estatal pessoas que, por imperativo constitucional, deveriam encontrar-se por ela abrangidas.

3. Ventilar-se a possibilidade de desrespeito ou prejuízo a alguém, em função de sua orientação sexual, seria dispensar tratamento indigno ao ser humano. Não se pode, simplesmente, ignorar a condição pessoal do indivíduo, legitimamente constitutiva de sua identidade pessoal (na qual, sem sombra de dúvida, se inclui a orientação sexual), como se tal aspecto não tivesse relação com a dignidade humana.

4. As noções de casamento e amor vêm mudando ao longo da historia ocidental, assumindo contornos e formas de manifestação e institucionalização plurívocos e multifacetados, que num movimento de transformação permanente colocam homens e mulheres em face de distintas possibilidades de materialização das trocas afetivas e sexuais.

5. A aceitação de uniões homossexuais é um fenômeno mundial - em alguns países de forma mais implícita - com o alargamento da compreensão do conceito de família dentro das regras já existentes; em outros de maneira explícita, com a modificação do ordenamento jurídico feita de modo a abarcar legalmente a união afetiva entre pessoas do mesmo sexo.

6. O Poder Judiciário não pode se fechar às transformações sociais, que, pela sua própria dinâmica, muitas vezes se antecipam às modificações legislativas.

7. Uma vez reconhecida, numa interpretação dos princípios norteadores da constituição pátria, a união homossexual como possível de ser abarcada dentro do conceito de entidade familiar e afastados quaisquer impedimentos de natureza atuarial, deve a relação da Previdência para com os casais de mesmo sexo dar-se nos mesmos moldes das uniões estáveis entre heterossexuais, devendo ser exigido dos primeiros o mesmo que se exige dos segundos para fins de comprovação do vínculo afetivo e dependência econômica presumida entre os casais (art. 16, I, da Lei $\mathrm{n}^{\circ}$ 8.213/91), quando do processamento dos pedidos de pensão por morte e auxílio-reclusão.

Por força da decisão liminar proferida nos autos acima referidos, o INSS editou as Instruções Normativas ns. 25/2000 e 50/2001, disciplinando a concessão do benefício ao companheiro/companheira homossexual. 
O Superior Tribunal de Justiça também já se pronunciou neste sentido, possibilitando ao companheiro(a) a percepção do benefício pensão por morte, como se vê da ementa do Recurso Especial no 395.904/RS (Relator Ministro Hélio Quaglia Barbosa, publicado no DJ de 06/02/2006):

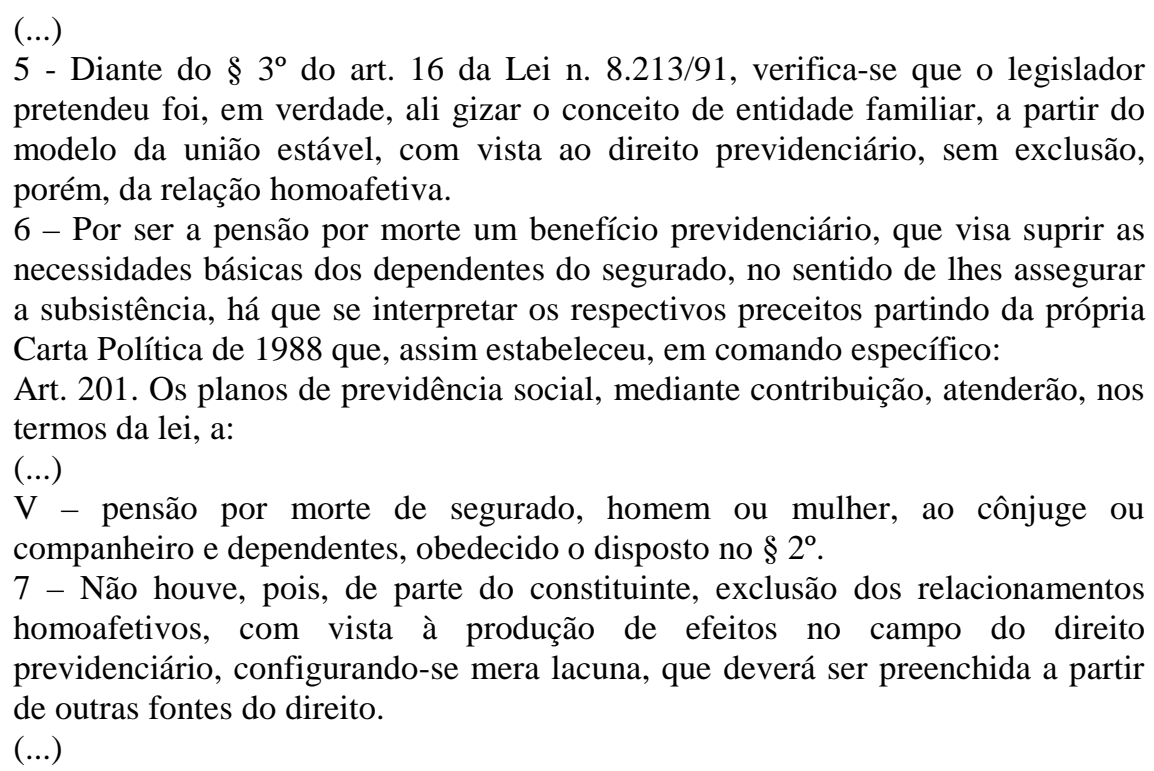

O voto do Ministro Relator é concluído com a seguinte ponderação:

\begin{abstract}
A União homoafetiva é, sem embargo, tema com intensos reflexos no mundo jurídico, não podendo, pois, o direito, em momento algum, fechar-se de modo a ignorar ou simplesmente repudiar a realidade existente; "e assim é, na verdade, pois o direito não regula os sentimentos. Contudo, dispõe ele sobre os efeitos que a conduta determinada por esse afeto, pode representar como fonte de direitos e deveres, criadores de relações jurídicas previstas nos diversos ramos do ordenamento, algumas interessando no Direito de Família, como o matrimônio e, hoje, a União Estável, outras ficando a margem dele." (REsp 148897/MG; Relator(a) Ministro RUY ROSADO DE AGUIAR, QUARTA TURMA Data do Julgamento 10/02/1998).

Relembre-se que, a própria mulher, por séculos a fio, era tratada pelo sistema jurídico como relativamente incapaz. (...)

(grifos do Relator)
\end{abstract}

Ao afastar a restrição indevidamente estabelecida pela política pública, o Judiciário fez prevalecer a unidade da Constituição (ao interpretar sistematicamente os artigos 201, $\mathrm{V}$, e $226, \S 3^{\circ}$ ) e a vedação do retrocesso social (impedindo, sem qualquer justificativa razoável, o tratamento diferenciado de efetivos dependentes).

Desta forma, manteve forte o conteúdo do direito fundamental, pois cuidou de assegurar a proteção previdenciária devida a quem de direito quando da ocorrência da contingência constitucionalmente prevista, sendo um importante exemplo de como o Poder 
Judiciário pode atuar em prol da efetividade dos direitos sociais sem adentrar no âmbito de atribuições dos outros Poderes, limitando-se a preservar a ordem jurídica, sua função típica.

\subsubsection{Beneficiários: menor sob guarda}

A redação originária do $\S 2^{\circ}$ do artigo 16 da Lei $n^{\circ} 8.213 / 91$ continha norma de equiparação, reconhecendo a condição de filho a menores que se encontravam em situação semelhante. Vejamos:

$\S 2^{\circ}$ Equiparam-se a filho, nas condições do inciso I, mediante declaração do segurado: o enteado; o menor que, por determinação judicial, esteja sob a sua guarda; e o menor que esteja sob sua tutela e não possua condições suficientes para o próprio sustento e educação.

Só que o dispositivo teve sua redação alterada pela Lei $\mathrm{n}^{\circ}$ 9.528/97, excluindo o menor sob guarda da proteção previdenciária e exigindo a efetiva comprovação da dependência econômica do enteado e do menor tutelado, antes presumida, verbis:

$\S 2^{\circ} \mathrm{O}$ enteado e o menor tutelado equiparam-se a filho mediante declaração do segurado e desde que comprovada a dependência econômica na forma estabelecida no Regulamento.

A alteração efetuada não encontra amparo no inciso V do artigo 201 do texto constitucional que não exclui, de antemão, a figura do menor sob guarda, permitindo a concessão do benefício desde que comprovada a relação de dependência.

De outro lado, esbarra frontalmente com a disposição contida no artigo 227 da Carta Magna que estabelece como dever da família, da sociedade e do Estado o cuidado com a criança e o adolescente, proibindo qualquer forma de discriminação. ${ }^{242}$

Além do mais, está em absoluta dissonância com o Estatuto da Criança e do Adolescente (Lei no 8.069/90) lei especial que, ao estabelecer a distinção entre guarda e tutela, nos artigos 33 e 36 respectivamente, torna evidente que o menor sob guarda, por não

\footnotetext{
${ }^{242}$ Nos termos do artigo 227 da CFR, "é dever da família, da sociedade e do Estado assegurar à criança e ao adolescente, com absoluta prioridade, o direito à vida, à saúde, à alimentação, à educação, ao lazer, à profissionalização, à cultura, à dignidade, ao respeito, à liberdade e à convivência familiar e comunitária, além de colocá-los a salvo de toda forma de negligência, discriminação, exploração, violência, crueldade e opressão".
} 
ter bens, necessita de mais assistência material do que o menor sob tutela, possuidor de bens e que necessita de um tutor para gerir seu patrimônio, até que atinja a maioridade. ${ }^{243}$

A inconstitucionalidade da norma previdenciária autoriza a aplicação do Estatuto da Criança e do Adolescente, lei especial em estrita consonância com o inciso V do artigo 201 e com o artigo 227 da Constituição Federal.

É possível afirmar que, de forma preponderante, as decisões judiciais de primeiro e segundo graus têm afastado a aplicação da regra restritiva e determinado a incidência da norma especial inscrita no artigo 33 da Lei $n^{\circ}$ 8.069/90 (Estatuto da Criança e do Adolescente).

O Superior Tribunal de Justiça, por sua vez, também vinha decidindo neste sentido, como se vê da ementa abaixo transcrita:

PROCESSUAL CIVIL E PREVIDENCIÁRIO. DECISÃO MONOCRÁTICA. NEGATIVA DE SEGUIMENTO. RELATOR. POSSIBILIDADE. ART. 557 DO CPC. REDAÇÃO DA LEI 9.756/98. INTUITO. DESOBSTRUÇÃO DE PAUTAS DOS TRIBUNAIS. MENOR SOB GUARDA. § $2^{\circ}$, ART. 16 DA LEI 8.213/91. EQUIPARAÇÃO A FILHO. FINS PREVIDENCIÁRIOS. LEI 9.528/97. ROL DE DEPENDÊNCIA. EXCLUSÃO. PROTEÇÃO AO MENOR. ART. 33, § $3^{\circ}$ DA LEI 8.069/90. ECA. GUARDA E DEPENDÊNCIA ECONÔMICA. COMPROVAÇÃO. BENEFÍCIO. CONCESSÃO. POSSIBILIDADE. PRECEDENTES DO STJ. AGRAVO INTERNO DESPROVIDO.

(...)

III - A redação anterior do $\S 2^{\circ}$ do artigo 16 da Lei 8.213/91 equiparava o menor sob guarda judicial ao filho para efeito de dependência perante o Regime Geral de Previdência Social. No entanto, a Lei $9.528 / 97$ modificou o referido dispositivo legal, excluindo do rol do artigo 16 e parágrafos esse tipo de dependente.

IV - Todavia, a questão merece ser analisada à luz da legislação de proteção ao menor.

V - Neste contexto, a Lei 8.069/90 - Estatuto da Criança e do Adolescente prevê, em seu artigo $33, \S 3^{\circ}$, que: "a guarda confere à criança ou adolescente a condição de dependente, para todos os fins e efeitos de direito, inclusive previdenciário".

VI - Desta forma, restando comprovada a guarda deve ser garantido o benefício para quem dependa economicamente do instituidor, como ocorre na hipótese dos autos. Precedentes do STJ."

(STJ, AgRg no RESP 727.716/CE, Relator Ministro Gilson Dipp, 5ª Turma, DJ 16/05/2005).

\footnotetext{
243 "Art. 33. A guarda obriga à prestação de assistência material, moral e educacional à criança ou adolescente, conferindo ao seu detentor o direito de opor-se a terceiros, inclusive aos pais.

$\S 1^{\circ} \mathrm{A}$ guarda destina-se a regularizar a posse de fato, podendo ser deferida, liminar ou incidentalmente, nos procedimentos de tutela e adoção, exceto no de adoção por estrangeiros.

$\S 2^{\circ}$ Excepcionalmente, deferir-se-á a guarda, fora dos casos de tutela e adoção, para atender a situações peculiares ou suprir a falta eventual dos pais ou responsável, podendo ser deferido o direito de representação para a prática de atos determinados."

"Art. 36. A tutela será deferida, nos termos da lei civil, a pessoa de até vinte e um anos incompletos.

Parágrafo único. O deferimento da tutela pressupõe a prévia decretação da perda ou suspensão do pátrio poder e implica necessariamente o dever de guarda."
} 
Contudo, decisões recentes da $3^{a}$ Seção da Corte Superior, especializada em matéria previdenciária, apontam para uma alteração da jurisprudência daquela Corte, não mais se reconhecendo o direito do menor sob guarda de figurar como beneficiário do segurado falecido, como nos mostra a seguinte ementa:

PREVIDENCIÁRIO. RECURSO ESPECIAL. PENSÃO POR MORTE. MENOR DESIGNADO. LEI $8.069 / 90$ (ECA). NÃO APLICAÇÃO. ENTENDIMENTO DA TERCEIRA SEÇÃO. LEI 9.528/97. INCIDÊNCIA. OBSERVÂNCIA DO PRINCÍPIO TEMPUS REGIT ACTUM. RESSALVA PESSOAL DO RELATOR. RECURSO PROVIDO.

1. A Terceira Seção deste Tribunal pacificou o entendimento no sentido de que, em se tratando de menor sob guarda designado como dependente de segurado abrangido pelo Regime Geral da Previdência Social, a ele não se aplicam as disposições previdenciárias do Estatuto da Criança e do Adolescente. Ressalva de ponto de vista pessoal do relator.

2. Recurso especial provido. ${ }^{24}$

Constam da fundamentação do voto do Relator, Ministro Arnaldo Esteves, os argumentos que levaram à modificação do entendimento, importantes de se conhecer embora com os quais não concordemos, com a máxima vênia dos Eminentes julgadores:

Logo de início, cumpre ressalvar entendimento pessoal contrário à posição majoritária que se firmou no âmbito da Terceira Seção desta Corte quanto ao tema. Em ambos os precedentes que seguem abaixo votei vencido na honrosa companhia dos Ministros NAPOLEÃO NUNES MAIA FILHO e JANE SILVA (Desembargadora convocada do TJMG). Assim, com a vênia dos que sustentam tese oposta, preservo a convicção de que o diploma normativo de regência da matéria é, efetivamente, o Estatuto da Criança e do Adolescente.

Todavia, o tema realmente não comporta maiores discussões no âmbito da Terceira Seção, que, reiterando entendimentos anteriores de suas Turmas, se consolidou no sentido da não aplicação da Lei 8.069/90 (Estatuto da Criança e do Adolescente) ao menor sob guarda para efeito de recebimento de pensão por morte. Confira-se:

"EMBARGOS DE DIVERGÊNCIA EM RECURSO ESPECIAL. DIREITO PREVIDENCIÁRIO. PENSÃO POR MORTE. MENOR SOB GUARDA. INCABIMENTO.

1. "Esta Corte já decidiu que, tratando-se de ação para fins de inclusão de menor sob guarda como dependente de segurado abrangido pelo Regime Geral da Previdência Social - RGPS, não prevalece o disposto no art. 33, $\S 3^{\circ}$ do Estatuto da Criança e Adolescente em face da alteração introduzida pela Lei no 9.528/97." (REsp n ${ }^{\circ}$ 503.019/RS, Relator Ministro Paulo Gallotti, in DJ 30/10/2006).

2. Embargos de divergência acolhidos." (EREsp 642.915/RS, Rel. Min. HAMILTON CARVALHIDO, DJe 30/6/08)

E, mais recentemente:

${ }^{244}$ Publicado no DJe de 09/03/2009, Relator Ministro Arnaldo Esteves. 
Pensão por morte. Regime Geral de Previdência Social. Menor sob guarda. Incidência da lei previdenciária vigente ao tempo do óbito do instituidor do benefício. Inaplicabilidade do Estatuto da Criança e do Adolescente. Precedentes da Terceira Seção. Embargos de divergência conhecidos e recebidos. (EREsp 801.214/BA, Rel. Min. NILSON NAVES, DJe 28/8/08)

Ao proferir voto acompanhando a posição do relator no EREsp 642.915/RS, a Ministra LAURITA VAZ historiou a evolução do entendimento da matéria nesta Corte:

“A princípio, era pacífico no âmbito deste Tribunal o entendimento segundo o qual o Estatuto da Criança e do Adolescente não garante a qualidade de dependente do menor sob guarda judicial por ser norma de cunho genérico, inaplicável aos benefícios mantidos pelo Regime Geral da Previdência Social, os quais, por sua vez, são regidos por lei específica. Devia, portanto prevalecer o art. $16, \S 2^{\circ}$, da Lei . $^{\circ} 8.213 / 91$, alterado pela Lei $n^{\circ} 9.528 / 97$, que suprimiu o menor sob guarda do rol dos dependentes do segurado.

Posteriormente, a matéria ficou bastante controvertida no âmbito desta Corte Superior de Justiça, tendo como ponto nodal à aparente antinomia entre o art. 16, $\S 2^{\circ}$, da Lei n. ${ }^{\circ} 8.213 / 91$ e o art. $33, \S 3^{\circ}$, da Lei n. ${ }^{\circ} 8.069 / 90$ (Estatuto da Criança e do Adolescente).

Assim, havia julgados que mantiveram o entendimento acima e outros que o reformularam, dentre os quais se encontram os de minha relatoria.

Entendia-se que ainda era assegurado ao menor sob guarda o direito à pensão por morte, devido ao falecimento do seu guardião, levando-se em conta as regras da legislação de proteção ao menor: a Constituição Federal - dever do poder público e da sociedade na proteção da criança e do adolescente (art. 227, caput, e $\S 3^{\circ}$, inciso II) e o Estatuto da Criança e do Adolescente - que confere ao menor sob guarda a condição de dependente para todos os efeitos, inclusive previdenciários (art. 33, § $3^{\circ}$, Lei n. ${ }^{\circ} 8.069 / 90$ ).

Ocorre que, diante da relevância social, jurídica e econômica da questão, bem como do atual posicionamento predominante dos membros que compõem esta Egrégia Terceira Seção, melhor analisando a matéria, concluo que razão assiste ao Instituto Previdenciário.

É assente na jurisprudência deste Tribunal, que o fato gerador para a concessão do benefício de pensão por morte é o óbito do segurado, devendo ser aplicada a lei vigente à época de sua ocorrência. Esse, por sinal, é o enunciado da recente Súmula n. ${ }^{\circ} 340$ desta Corte, in verbis:

"A lei aplicável à concessão de pensão previdenciária por morte é aquela vigente na data do óbito do segurado."

Dessa forma, não é possível a concessão da pensão por morte quando o óbito do guardião ocorreu sob o império da Lei n. ${ }^{\circ}$ 9.528/97, uma vez que o menor sob guarda não mais detinha a condição de dependente, conforme a lei previdenciária vigente.

Outro não é o entendimento do Supremo Tribunal Federal, que, em decisões unipessoais dos seus integrantes, tem aplicado o princípio tempus regit actum aos casos de pensão por morte de menor designado. Ilustrativamente:

DECISÃO AGRAVO DE INSTRUMENTO. PREVIDENCIÁRIO. PENSÃO POR MORTE: MENOR DESIGNADA BENEFICIÁRIA. ÓBITO DA SEGURADA POSTERIOR À VIGÊNCIA DA LEI N. 9.032/1995: INEXISTÊNCIA DE DIREITO ADQUIRIDO. PRINCÍPIO TEMPUS REGIT ACTUM. PRECEDENTES. AGRAVO E RECURSO EXTRAORDINÁRIO PROVIDOS.

Relatório

1. Agravo de instrumento contra decisão que não admitiu recurso extraordinário, interposto com base no art. 102, inc. III, alínea a, da Constituição da República.

2. O recurso inadmitido tem como objeto o seguinte julgado do Tribunal Regional Federal da $5^{\mathrm{a}}$ Região:

'PREVIDENCIÁRIO. DEPENDÊNCIA DESIGNADA. MENOR. PENSÃO. LEI VIGENTE. COMPROVAÇÃO DA DEPENDÊNCIA MEDIANTE CTPS. 
1. Designação de dependente menor, realizada pelo autor do benefício, nos moldes da Lei 8.213/91, vigente à época.

2. Excluída a designação pela Lei 9.032 , de 28/04/95, mas mantida ainda a condição de menor e a qualidade de dependente possibilita o requerimento do benefício, face direito previsto na lei anterior. 3. Uma vez comprovada a dependência econômica do menor, mediante CTPS, inquestionável o direito à pensão por morte requerida. 4. Apelação e remessa oficial improvidas (fl. 166).

3. A decisão agravada teve como fundamento para a inadmissibilidade do recurso extraordinário a circunstância de que a resolução da controvérsia trazida nos autos configuraria matéria fática, não passível de apreciação em sede extraordinária (fls. 221-222).

4. O Agravante alega que teria sido contrariado o art. $5^{\circ}$, inc. XXXVI, da Constituição da República. Sustenta que: 'A condição de dependente designado gerava, apenas, uma expectativa de que lhe seria reconhecido um direito quando adviesse o fato ou situação jurídica prevista em lei, in casu, a morte do segurado que efetivou a designação. De fato, os benefícios previdenciários, como sabido, são regulados pela legislação vigente à época em que se encontram presentes todos os requisitos necessários à sua obtenção. No caso específico da pensão por morte, portanto, aplica-se a lei da época do falecimento do segurado' (fls. 198, 199 e 201).

Apreciada a matéria trazida na espécie, DECIDO.

5. Razão de direito assiste ao Agravante.

6. A jurisprudência do Supremo Tribunal Federal firmou-se no sentido de que, em matéria previdenciária, a lei de regência é a vigente ao tempo em que reunidos os requisitos para a concessão do benefício (princípio tempus regit actum). Esse entendimento foi reafirmado pelo Plenário deste Supremo Tribunal no julgamento dos Recursos Extraordinários ns. 416.827 e 415.454 em 8 de fevereiro de 2007.

7. Na espécie vertente, a menor foi designada dependente na vigência da Lei n. 8.213/91. Todavia, o óbito da parte segurada ocorreu em 30.5.1995 (fl. 26), portanto, na vigência da Lei n. 9.032, de 28.4.1995. Assim, não há que se falar em direito adquirido ao regime jurídico anterior à data do óbito do segurado designante. Nesse sentido, em caso análogo, a seguinte decisão: 'DECISÃO: Trata-se de recurso extraordinário (art. 102, III, a, da Constituição) interposto pelo INSS de acórdão do Tribunal Regional Federal da $5^{\text {a }}$ região cuja ementa tem o seguinte teor (fls. 64): 'Previdenciário. Pensão por morte. Menor sob a guarda de falecido segurado. Designação como dependente antes da edição da Lei $\mathrm{n}^{\circ}$ 9.032/95. Ato jurídico perfeito e direito adquirido. Apelação e remessa oficial improvidas'. Alega-se violação da proteção constitucional ao direito adquirido e ao ato jurídico perfeito (art. $5^{\circ}, \mathrm{XXXVI).} \mathrm{Em} \mathrm{seu} \mathrm{parecer,} \mathrm{a} \mathrm{Procuradoria-Geral}$ da República manifesta-se pelo conhecimento e provimento do recurso (fls. 109). É o breve relatório. Decido. Entendo que o Tribunal a quo aplicou corretamente o art. $5^{\circ}$, XXXVI, da Constituição federal. O Supremo Tribunal Federal firmou jurisprudência acerca da inexistência de direito adquirido a regime jurídico (cf. o recente julgamento da ADI 3.105). Se, na ação, pleiteia-se concessão de benefício de pensão por morte a menor designada como dependente nos termos do art. 16, IV, da Lei 8.213/1991, e verificando-se que esse tipo de designação foi extinta, em 1995, pela Lei 9.032, não há direito adquirido ao benefício nos casos em que o falecimento do beneficiário tenha ocorrido depois da alteração legislativa. É o que ocorre na espécie, visto que a beneficiária que designou a menor faleceu em 16.01.2001, depois, portanto, da alteração do regime jurídico aplicável. Do exposto, dou provimento ao presente recurso' (RE 435.928, Rel. Min. Joaquim Babosa, DJ 22.3.2005, trânsito em julgado em 22.4.2005). E, ainda, os julgados nas seguintes decisões monocráticas: RE 494.673, Rel. Min. Ricardo Lewandowski, DJ 12.9.2007, trânsito em julgado em 28.9.2007; RE 472.275, Rel. Min. Joaquim Barbosa, DJ 27.3.2007, trânsito em julgado em 20.4.2007; e RE 409.069, Rel. Min. Sepúlveda Pertence, DJ 30.10.2006, trânsito em julgado em 27.11.2006; RE 540.945, de minha relatoria, DJE 22.8.2008. Dessa orientação divergiu o acórdão recorrido. 
8. Pelo exposto, com fundamento no art. $544, \S \S 3^{\circ}$ e $4^{\circ}$, do Código de Processo Civil, dou provimento ao agravo e, desde logo, ao recurso extraordinário, nos termos do art. 557, $\S 1^{\circ}$-A, do Código de Processo Civil, para declarar indevida a concessão de pensão por morte à Recorrida, a partir da edição da Lei n. 9.032/1995, conforme a jurisprudência deste Supremo Tribunal Federal. Ficam invertidos os ônus da sucumbência, ressalvada eventual concessão de justiça gratuita. Publique-se. (Rel. Min. CÁRMEM LÚCIA, DJe 22/10/08).

Os fundamentos que têm sido utilizados pelo Poder Judiciário de primeira e segunda instâncias para afastar a alteração promovida pela Lei $n^{\circ}$ 9.528/97 - com a ressalva da jurisprudência recente do Superior Tribunal de Justiça - estão em sintonia com o conteúdo do direito fundamental à Previdência Social, na medida em que asseguram a prestação previdenciária aos dependentes do segurado que dele dependem efetivamente, recebendo a proteção estatal no momento em que mais precisam. Não por caridade, mas por direito.

Também atendem os postulados constitucionais que estabelecem o dever da família, da sociedade e do Estado de prover os direitos da criança e do adolescente, entre os quais os direitos previdenciários (CFR, art. 227, § $3^{\circ}$ ).

Não há qualquer justificativa lógica e razoável para excluir do rol de beneficiários um dos dependentes que mais necessita do benefício: o menor sob guarda. Não obstante já destituído de qualquer bem - pois se o tivesse seria colocado sob tutela de outrem, pretendeu o legislador retirar do menor a sua única fonte de subsistência, justamente no momento em que mais precisa de auxílio.

A alteração pretendida, ao excluir o menor sob guarda e manter como dependentes o enteado e o menor tutelado, não atende, entre outros, aos princípios da solidariedade, da unidade da Constituição, da proibição do retrocesso, da isonomia e da razoabilidade, devendo ser rechaçada pelo Poder Judiciário.

Pelas razões expostas, ousamos discordar do atual entendimento adotado pelo Superior Tribunal de Justiça.

\subsubsection{Benefício de auxílio-doença: Programa de Cobertura Previdenciária Estimada (COPES) - Alta programada}

O benefício de auxílio-doença é disciplinado pelos artigos 59 a 63 da Lei $\mathrm{n}^{\circ}$ 8.213/91. Seu fundamento constitucional é o inciso I do artigo 201. 
Em linhas gerais, é devido ao segurado incapacitado para o exercício de suas atividades habituais por mais de quinze dias, exigindo-se o cumprimento da carência de doze contribuições.

O artigo 62 da Lei referida trata da cessação do benefício, nos seguintes termos:

Art. 62. O segurado em gozo de auxílio-doença, insuscetível de recuperação para sua atividade habitual, deverá submeter-se a processo de reabilitação profissional para o exercício de outra atividade. Não cessará o benefício até que seja dado como habilitado para o desempenho de nova atividade que lhe garanta a subsistência ou, quando considerado não recuperável, for aposentado por invalidez.

O dispositivo é bastante claro ao estabelecer a limitação temporal ${ }^{245}$ do benefício e apenas possibilitar a sua cessação quando devidamente comprovada: (i) a recuperação do segurado para o exercício de sua atividade habitual; (ii) não sendo possível a recuperação, a reabilitação para outra atividade; (iii) não sendo possível a recuperação ou a reabilitação, estiverem presentes os requisitos para a concessão da aposentadoria por invalidez.

A comprovação exigida sempre foi feita através de perícia médica, realizada por médicos do INSS. Quando da realização do exame, o Perito estabelecia uma estimativa de recuperação e já agendava uma nova consulta, via de regra, no prazo de sessenta a noventa dias.

No entanto, o aumento excessivo de pedidos de benefícios por incapacidade fez com que o INSS invertesse o ônus da comprovação da incapacidade, deixando-a a cargo do segurado. Confira-se a novidade:

O problema adquiriu contornos muito maiores com a evolução do volume dos benefícios por incapacidade já retratada na introdução, que levou a Previdência Social a efetuar quase cinco milhões de perícias médicas nos anos de 2004 e 2005. Com isso, buscou-se uma solução para a diminuição do número de perícias médicas. E ela foi encontrada justamente na administração das perícias intermediárias dos benefícios já em manutenção. Para isso, editou-se a Orientação Interna da Diretoria de Benefícios do INSS no 130 , de 13 de outubro de 2005, documento interno, não publicado em diário oficial e destinado aos médicos peritos do INSS, que estabeleceu o sistema de Cobertura Previdenciária Estimada - COPES.

O documento em questão, embora tenha redação extremamente obscura, estabeleceu a possibilidade de o médico determinar até um limite de cento e oitenta dias, no qual o benefício seria automaticamente cessado sem a necessidade de nova perícia para averiguar a efetiva cessação da incapacidade. Caso discordasse da assim chamada alta programada, cabia ao próprio segurado,

${ }^{245}$ Nos termos do artigo 101 da Lei no 8.213/91, "o segurado em gozo de auxílio-doença, aposentadoria por invalidez e o pensionista inválido estão obrigados, sob pena de suspensão do benefício, a submeter-se a exame médico a cargo da Previdência Social, processo de reabilitação por ela prescrito e custeado, e tratamento dispensado gratuitamente, exceto o cirúrgico e a transfusão de sangue, que são facultativos". 
num prazo determinado após a cessação do benefício, protocolar pedido de reconsideração, que dava ensejo à marcação de uma nova perícia para averiguar a pertinência da cessação ou a necessidade de restabelecimento do benefício.

A alta programada é um magnífico exemplo de como, no Brasil, as limitações de natureza prática dão ensejo a restrições de direitos fundamentais. Explica-se.

A medida, do ponto de vista administrativo, foi um absoluto sucesso. Com efeito, as estatísticas mostram que o número de perícias caiu de $4.961 .039 \mathrm{em}$ 2005 para 382.545 em 2006, número pouco superior ao registrado no ano de 1988 e muito inferior a todos os outros anos a partir de $1989 .{ }^{246}$

Posteriormente, em face do grande número de ações judiciais propostas, o INSS editou a Ordem Interna INSS/DIRBEN 138/2006, aperfeiçoando o sistema COPES. A nova medida possibilitou ao segurado "protocolar pedido de prorrogação a partir de quinze dias antes da data fixada para a cessação do benefício até a data em questão. Após a cessação, persiste a possibilidade de protocolar pedido de reconsideração em um prazo de até trinta duas após a cessação do benefício."247

Por fim, referidas Ordens Internas foram incluídas nos $\S \S 1^{\circ}, 2^{\circ}$ e $3^{\circ}$ do artigo 78 do Decreto $\mathrm{n}^{\circ} 3.048 / 99$, através do Decreto $\mathrm{n}^{\circ} 5.844 / 2006$. $^{248}$

Concluímos, acompanhando o Autor do trabalho referido, pelo desastre da medida sob a ótica jurídica, pois através da edição de um ato infralegal houve efetiva restrição a direito fundamental social, vez que: ( $i$ ) a ordem interna não foi tornada pública, mas apenas divulgada aos funcionários do INSS; (ii) mesmo quando houve a "conversão" da OI em dispositivo inscrito no Decreto $n^{\circ} 3.048 / 99$, é certo que a Lei $n^{\circ} 8.213 / 91$ estabelece que o benefício deve ser pago até que comprovada a cessação da causa que lhe deu origem, ônus da autarquia e não do segurado, já que ao réu compete demonstrar a existência de causa impeditiva, modificativa e extintiva do direito do autor, nos termos do artigo 333, II, do Código de Processo Civil.

A "alta programada" é um exemplo típico de alteração inconstitucional da legislação previdenciária, vez que formulada pela autarquia previdenciária com o claro propósito de reduzir o número de benefícios em manutenção e o seu quadro de peritos.

246 BATISTA, Flávio Roberto. Benefícios Previdenciários por Incapacidade no Regime Geral de Previdência Social. Dissertação de Mestrado apresentada na Faculdade de Direito, Universidade de São Paulo, 2008. p. 144-145.

${ }^{247}$ Idem, ibidem, p. 150.

248 “Art. 78. (...)

$\S 1^{\circ} \mathrm{O}$ INSS poderá estabelecer, mediante avaliação médico-pericial, o prazo que entender suficiente para a recuperação da capacidade para o trabalho do segurado, dispensada nessa hipótese a realização de nova perícia.

$\S 2^{\circ}$ Caso o prazo concedido para a recuperação se revele insuficiente, o segurado poderá solicitar a realização de nova perícia médica, na forma estabelecida pelo Ministério da Previdência Social.

$\S 3^{\circ} \mathrm{O}$ documento de concessão do auxílio-doença conterá as informações necessárias para o requerimento da nova avaliação médico-pericial." 
Nenhuma preocupação, como visto, com o direito fundamental em si, mas apenas com os seus custos operacionais.

Fere fortemente o conteúdo do direito fundamental na medida em que impede a concessão da prestação previdenciária mesmo estando presente a contingência prevista constitucionalmente (doença).

Por óbvio que inúmeras ações judiciais foram ajuizadas, tanto individualmente como em sede coletiva (por meio de ação civil pública).

No âmbito individual, especialmente por via de mandado de segurança, denota-se a tendência jurisprudencial (de primeiro e segundo graus) de reconhecer a inconstitucionalidade da alta programada, destacando-se alguns trechos de decisões que consideramos elucidativas $^{249}$ :

O artigo 50 da Lei ${ }^{\circ}$ 9.874/99, que regula o processo administrativo na órbita da Administração Pública Federal, aplicável subsidiariamente aos feitos previdenciários, por força do artigo 69 da mesma lei, reza que os atos administrativos que neguem, limitem ou afetem direitos ou interesses dos administrados devem ser motivados, com a indicação dos fatos e fundamentos jurídicos.

Se o INSS pré-fixa o termo final do benefício previdenciário, supondo que em data futura a incapacidade irá cessar, é óbvio que na data da cessação do benefício não haverá modificação do ato. Em outros termos: o benefício cessará automaticamente, sem qualquer fundamentação. Não é legítimo enxugar os serviços administrativos à custa das garantias dos cidadãos, dentre as quais se encontra a motivação dos atos administrativos.

Os fins não justificam os meios. Há parâmetros ético-jurídicos que devem ser respeitados pelos órgãos estatais em suas decisões, conquanto administrativas. Ato sem motivação é ato nulo, írrito, e não pode subsistir em um Estado fundado em bases democráticas. ${ }^{250}$

A sistemática instituída pelo Programa de Cobertura Previdenciária EstimadaCOPES, também conhecido como Data Certa ou, ainda, Alta Programada, estabelece a prefixação de data em que o trabalhador deverá retornar à sua rotina de trabalho, sem que se tenha certeza de que o empregado está plenamente recuperado e em condições de retomar suas atividades laborais, o que, ao meu ver, malfere os mais comezinhos princípios do Direito Previdenciário e, até mesmo, do Direito Constitucional.

Com efeito, no âmbito constitucional, tem-se que a Carta Magna traz expressamente em seu texto, em diversas passagens, que a ordem social tem por fundamento a dignidade da pessoa humana e por objetivo o bem-estar e a justiça social, cabendo ao Estado o dever de implementar políticas públicas de proteção e recuperação da saúde; a Lei de Benefícios Previdenciários, por sua vez, prevê que a Previdência Social tem por fim assegurar os meios indispensáveis à sua manutenção, quando eles não puderem, por seus próprios meios, provê-la, por terem sido acometidos por infortúnios sociais (art. $1^{\circ}$ da Lei 8.213/91).

Ora, a implementação, pelo INSS, da intitulada Alta Programada põe por terra todos os propósitos acima enumerados, na medida em que determina a interrupção de benefício que vinha sendo pago em razão de o trabalhador estar

${ }^{249}$ Mencionadas na dissertação apresentada por Flávio Roberto Batista, indicada na bibliografia.

250 BRASIL. Justiça Federal de São Paulo, 19 ${ }^{a}$ Subseção Judiciária, $4^{\mathrm{a}}$ Vara Federal, Processo $\mathrm{n}^{\mathrm{o}}$ 2006.61.19.005783-2, DO de 27/07/2007, p. 143. 
temporariamente impossibilitado de prover seu sustento sem que se saiba, ao certo, se o segurado já está prontamente restabelecido e em condições de voltar ao trabalho. ${ }^{251}$

A medida é manifestamente inconstitucional por implicar grave retrocesso social, incluindo uma restrição indevida e incompatível com a contingência eleita pela Constituição Federal. E não atende, como pretendido pelos seus formuladores, à eficiência de que trata o artigo 37 da Constituição Federal, eficiência administrativa e não econômica, ou seja, eficiência que se traduz na busca pelo melhor resultado sob o ponto de vista da melhoria das condições de bem-estar da coletividade.

Felizmente, ao menos no âmbito das ações individuais, o Judiciário tem, em sua maioria, prontamente afastado sua aplicação, preservando o conteúdo do direito fundamental.

\title{
3.1.5. Custeio - Regime Geral de Previdência Social: obrigatoriedade de recolhimento de contribuições previdenciárias pelo segurado aposentado que volta a trabalhar
}

O trabalhador já aposentado, de acordo com a redação original das Leis ns. 8.212/91 e 8.213/91, não estava sujeito a novamente contribuir para os cofres da Previdência, caso voltasse a trabalhar. Foi então editada a Lei $n^{\circ} 9.032 / 95$, acrescentando o $\S 4^{\circ}$ ao artigo 12 da Lei de Custeio, do seguinte teor:

\begin{abstract}
O aposentado pelo RGPS que estiver exercendo ou que voltar a exercer a atividade abrangida por este Regime é segurado obrigatório em relação a essa atividade, ficando sujeito às contribuições de que trata esta Lei, para fins de custeio da seguridade social.
\end{abstract}

A alteração introduzida pela Lei no 9.032/95 não se compatibiliza com o regime de repartição simples adotado pelo texto constitucional originário, baseado no pacto intergeracional através do qual os trabalhadores de hoje pagam, com suas contribuições, os proventos dos inativos, da mesma forma que terão seus proventos pagos pela próxima geração. Desta forma, ao ser concedido o benefício de aposentadoria, o pressuposto é que o segurado já trabalhou e contribuiu o necessário e suficiente, passando então a usufruir os proventos a que tem direito. Ainda que retorne ao mercado de trabalho, está imune à

${ }^{251}$ BRASIL. TRF - 5a Região, Segunda Turma, Processo no $2006.05 .00 .020480-1-S E$, DO de 07/01/2008. Disponível em: <http://www.trf5.jus.br>. Acesso em 11 de setembro de 2009. 
incidência do pagamento de qualquer outra contribuição previdenciária, pois já cumpriu com seu quinhão.

Como se não bastasse, fere também o princípio constitucional da isonomia vez que trata de forma diferenciada trabalhadores que se encontram na mesma situação.

A mesma Lei $\mathrm{n}^{\circ}$ 9.032/95, que determinou a incidência da contribuição previdenciária ao segurado aposentado que retorna ao mercado de trabalho, também inseriu o $\S 2^{\circ}$ ao artigo 18 da Lei de Benefícios (Lei $n^{\circ} 8.213 / 91$ ), apenas possibilitando a este aposentado a percepção dos benefícios de salário-família e reabilitação profissional.

Ora, ou bem o segurado aposentado contribui como os demais e tem direito a receber todos os dez benefícios do artigo 18 para os quais se destinam as contribuições, ou bem não contribui com nada, vez que não receberá qualquer contrapartida.

A solidariedade que sustenta a Previdência Social determina que todos contribuam para que todos possam receber, quando oportuno, o quinhão que ajudaram a formar. Mas não autoriza o tratamento desigual que a Lei $\mathrm{n}^{\circ}$ 9.032/95 instituiu. A nosso ver, não se coaduna com a solidariedade desejada pelo legislador constituinte a imposição de dever em via única, ou seja, somente para efeito de contribuição.

No julgamento do Recurso Extraordinário no 437.640-7/RS (Relator Ministro Sepúlveda Pertence, publicado no DJ de 02/03/2007), o Supremo Tribunal Federal analisou a constitucionalidade da contribuição previdenciária cobrada do aposentado que retorna à atividade, instituída pela Lei $\mathrm{n}^{\circ}$ 9.032/95 em nova redação dada ao $\S 4^{\circ}$ do artigo 12 da Lei $n^{\circ} 8.212 / 91$.

A Corte Suprema concluiu pela constitucionalidade do dispositivo, ao fundamento de que a contribuição está amparada no princípio da universalidade do custeio da Previdência Social (CF, art. 195), bem como no $\S 4^{\circ}$ do artigo 201, que "remete à lei os casos em que a contribuição repercute nos benefícios".

Baseou-se o Relator nos fundamentos adotados pelo Supremo Tribunal Federal na ADIN 3.105-8/DF (tratada no item 3.1.6 deste Capítulo, a seguir).

Não obstante o julgamento tenha sido unânime, no Voto-Vista apresentado pelo Ministro Carlos Britto foram tecidas importantes considerações envolvendo os princípios da universalidade, da solidariedade e da isonomia, como segue:

(...)

6. Pois bem, devo reconhecer que, após o entendimento majoritário que se adotou no julgamento da referida ADI 3.105, seria difícil sustentar qualquer tipo de necessária correspondência entre a contribuição exigida dos aposentados pelo RGPS e o incremento dos respectivos proventos. Tudo desembocaria no caráter 
ortodoxamente tributário da contribuição para a Previdência Social (a ser financiada por toda a sociedade, de forma solidária), tal como sustentado pelo eminente Ministro Pertence, naquela oportunidade e no presente caso.

(...)

10. Em essência, portanto, restou ao trabalhador-aposentado: de um lado, o dever jurídico de contribuir para a Previdência Social $\left(\$ 4^{\circ}\right.$ do art. 12 da Lei 8.212/91); de outro, usufruir tão somente do serviço de reabilitação profissional e do benefício do salário-família.

11. Já no âmbito das prestações a que fazem jus os demais trabalhadores, ou seja, aqueles que ainda não se aposentaram, leio o art. 18 da Lei ${ }^{\circ} 8.213 / 91$ :

(...)

12. Ora bem, diante desse tratamento normativo gritantemente diferenciado, é de se perguntar: a Lei $\mathrm{n}^{\circ}$ 9.032/95 negou o princípio da isonomia, ao restringir o rol de prestações em favor do trabalhador de que trata este processo? Antes de qualquer resposta, lembro que o diploma então regulador da situação do aposentado pela Previdência Social que voltava ao trabalho (Lei $n^{\circ} 6.243 / 1975$ ) previa, em seu art. $1^{\text {o: }}$

"Art. $1^{\circ} \mathrm{O}$ aposentado pela Previdência Social que voltar a trabalhar em atividade sujeita ao regime da Lei no 3.807 ("Antiga Lei Orgânica da Previdência Social"), de 26 de agosto de 1960, terá direito, quando dela se afastar, a um pecúlio constituído pela soma das importâncias correspondentes às suas próprias contribuições, pagas ou descontadas durante o novo período de trabalho, corrigido monetariamente e acrescido de juros de $4 \%$ (quatro por cento) ao ano, não fazendo jus a outras prestações, salvo as decorrentes de suas condição de aposentado ..."

13. Dessa leitura, fácil concluir que o retorno do aposentado ao trabalho implicava o dever da contribuição previdenciária, sim, mas sob a regra de que o somatório delas lhe seria devolvido na forma de um pecúlio. E o que temos hoje? Temos que a Lei 9.032/95 definiu o trabalhador-aposentado como segurado obrigatório da Previdência Social, porém sem o anterior direito aos mesmos benefícios que são conferidos aos trabalhadores ainda não aposentados. Pior: sem direito a pecúlio e sem direito aos mesmos benefícios que são conferidos aos trabalhadores ainda não aposentados.

(...)

19. É o que me basta, Sr. Presidente, para entender conspurcado o princípio constitucional da isonomia. Isto porque não encontro em nossa Lei Fundamental normação que legitime o desprestígio conferido pela Lei $n^{\circ}$ 9.032/95 aos trabalhadores aqui referidos.

20. Com efeito, a Carta de Outubro versa a aposentadoria como um "benefício". Não como um malefício. E se tal aposentadoria se dá por efeito do exercício regular de um direito (aposentadoria voluntária), é claro que esse regular exercício de um direito não pode representar uma "capitus deminutio" perante aqueles ainda não contemplados com a possibilidade de optar entre se inativar de vez, ou permanecer trabalhando.

21. Por este nosso modo de ver as coisas, tem-se, de um lado, o exercício pleno de um direito social, que é o direito ao trabalho (cabeça do art. $6^{\circ}$ ); de outro, o pleno gozo do direito à aposentadoria pelo Regime Geral de Previdência Social, também definido como direito social pelo mesmo art. $6^{\circ}$ da CF combinado com o $\S 7^{\circ}$ do art. 201. Ambos com sua própria natureza jurídica, é certo, mas passíveis de contemplar uma só e mesma pessoa física.

22. Acresce que a defesa deste nosso ponto de vista concretiza o protoprincípio da valorização do trabalho, que a Magna Carta de 1988 versou como fundamento da República Federativa do Brasil (inciso IV do art. $1^{\circ}$ ), princípio da ordem econômica (inciso VIII do art. 170) e base de toda a ordem social (art. 193). (...). 
Apesar das lúcidas observações do Ministro Carlos Ayres Britto, ele acompanhou o voto do Relator, vez que a discussão não foi ventilada no Tribunal de origem, inocorrendo o prequestionamento.

Os fundamentos utilizados por sua Excelência desnudam, em boa medida, o verdadeiro intuito da alteração legislativa editada, qual seja, o aumento puro e simples das contribuições previdenciárias, sem qualquer contrapartida àquele obrigado ao seu recolhimento.

Ora, um dos pilares da Previdência, que integram o conteúdo do direito fundamental, é a regra inscrita no artigo $195, \S 5^{\circ}$, da Constituição Federal, pela qual "os benefícios ou serviços só podem ser criados, majorados ou estendidos mediante a correspondente fonte de custeio total".

O que temos aqui, como bem apontado pelo Ministro Carlos Britto, é a imposição de recolhimento da contribuição previdenciária, sem que possibilite a tal segurado o usufruto dos benefícios e serviços a ela correspondentes, como sói acontecer com os demais segurados que trabalham.

$\mathrm{O}$ entendimento adotado à unanimidade pela Corte Suprema apenas destaca a solidariedade sob a ótica do custeio, ignorando-a sob a sua outra face (a do benefício).

A política pública ratificada pelo Supremo Tribunal Federal implica grande retrocesso social e não atende aos critérios da impessoalidade, da moralidade, da razoabilidade e da proporcionalidade.

Se implica, de outro lado, em alguma eficiência econômica, este resultado não tem estatura suficiente a se sobrepor ao direito fundamental. Pelo menos, não deveria ter.

\subsubsection{Custeio - Regime próprio de Previdência Social: contribuição previdenciária dos servidores públicos inativos}

Trataremos inicialmente da evolução legislativa (em sentido lato) acerca da instituição da cobrança de contribuição social incidente sobre os proventos recebidos pelos servidores públicos inativos e pensionistas.

A discussão é interessante, pois no caso dos segurados aposentados vinculados ao Regime Geral, a obrigatoriedade de recolhimento de contribuição previdenciária por parte daqueles que voltam a trabalhar foi estabelecida por lei ordinária e pouca discussão causou, tanto no âmbito doutrinário como na esfera judicial. 
O mesmo não ocorreu com a instituição da contribuição dos inativos do setor público.

Embora não se exija que o sujeito passivo volte a trabalhar, o fundamento da cobrança é o mesmo nos dois casos, qual seja, a busca do equilíbrio financeiro e atuarial. Vejamos.

O texto originário da Constituição de 1988 não continha qualquer previsão de incidência desta contribuição social.

Foi alterado pela Emenda Constitucional $n^{\circ} 03 / 1993$, sendo introduzido o $\S 6^{\circ}$ ao artigo 40, com o seguinte teor:

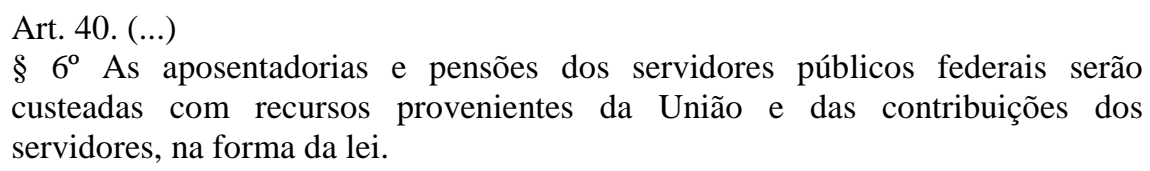

Neste contexto, foi editada a Medida Provisória $n^{\circ}$ 1.415, de 29 de abril de 1996, que, dando nova redação ao artigo 231 da Lei $n^{\circ}$ 8.112/1990, instituiu a contribuição dos servidores inativos, verbis:

Art. 231. O plano de Seguridade Social do servidor será custeado com o produto da arrecadação de contribuições sociais obrigatórias dos servidores ativos e inativos dos três Poderes da União, das autarquias e das fundações públicas.

A Medida Provisória $n^{\circ} 1.415$ foi atingida pela caducidade, não sendo convertida em lei.

A Emenda Constitucional $n^{\circ} 20 / 1998$, por sua vez, alterou radicalmente a redação do $\S 6^{\circ}$ do artigo 40, nada mais mencionando acerca da cobrança de contribuição previdenciária por parte dos servidores inativos.

Foi publicada, no ano de 1999, a Lei $n^{\circ} 9.873$, estabelecendo a contribuição dos inativos no setor público. Dispunha em seu artigo $1^{\circ}$ que:

Art. $1^{\circ}$ A contribuição social do servidor público civil, ativo e inativo, e dos pensionistas dos três Poderes da União, para a manutenção do regime de previdência social dos seus servidores, será de onze por cento, incidente sobre a totalidade da remuneração de contribuição, de provento ou da pensão.

(...) 
O dispositivo foi declarado inconstitucional pelo Supremo Tribunal Federal, no julgamento da Ação Direta de Inconstitucionalidade nº 2.010-2/DF, Relator Ministro Celso de Mello, vez que a exação não poderia ser disciplinada por lei ordinária.

A cobrança de contribuição dos inativos também foi objeto de várias leis estaduais, também declaradas inconstitucionais pela Corte Suprema (ADIN 2.189-3/PR, ADIN 2.176-1/RJ, ADIN 2.196-6/RJ).

Atendendo às diretrizes estabelecidas pela Corte Suprema, o Poder Executivo elaborou então um projeto de emenda constitucional, aprovado de acordo com as regras constitucionais e que culminou com a instituição válida da exação no ordenamento, por força da Emenda Constitucional no 41/2003.

O Supremo Tribunal Federal também foi instado a se manifestar sobre a constitucionalidade/inconstitucionalidade da nova contribuição e no julgamento das Ações Diretas de Inconstitucionalidade ns. 3.105 e 3.128 considerou sanado o vício formal antes existente e, no mérito, declarou a constitucionalidade da cobrança pretendida.

A ADIN 3.105-8/DF, Relator para o acórdão Ministro Cezar Peluso - DJ 18/02/2005, encontra-se assim ementada:

EMENTAS: 1. Inconstitucionalidade. Seguridade social. Servidor público. Vencimentos. Proventos de aposentadoria e pensões. Sujeição à incidência de contribuição previdenciária. Ofensa a direito adquirido no ato de aposentadoria. Não ocorrência. Contribuição social. Exigência patrimonial de natureza tributária. Inexistência de norma de imunidade absoluta. Emenda Constitucional $n^{\circ} 41 / 2003$ (art. $4^{\circ}$, caput). Regra não retroativa. Incidência sobre fatos geradores ocorridos depois do início de sua vigência. Precedentes da Corte. Inteligência dos arts. $5^{\circ}$, XXXVI, 146, III, 149, 150, I e III, 194, 195, caput, II e $\$ 6^{\circ}$, da CF, e art. $4^{\circ}$, caput, da EC $\mathbf{n}^{\circ} 41 / 2003$. No ordenamento jurídico vigente, não há norma, expressa nem sistemática, que atribua à condição jurídico-subjetiva da aposentadoria de servidor público o efeito de lhe gerar direito subjetivo como poder de subtrair ad aeternum a percepção dos respectivos proventos e pensões à incidência da lei tributária que, anterior ou ulterior, os submeta à incidência de contribuição previdencial. Noutras palavras, não há, em nosso ordenamento, nenhuma norma jurídica válida que, como efeito específico do fato jurídico da aposentadoria, lhe imunize os proventos e as pensões, de modo absoluto, à tributação de ordem constitucional, qualquer que seja a modalidade do tributo eleito, donde não houver, a respeito, direito adquirido com o aposentamento.

2. Inconstitucionalidade. Ação direta. Seguridade social. Servidor público. Vencimentos. Proventos de aposentadoria e pensões. Sujeição à incidência de contribuição previdenciária, por força de Emenda Constitucional. Ofensa a outros direitos e garantias individuais. Não ocorrência. Contribuição social. Exigência patrimonial de natureza tributária. Inexistência de norma de imunidade tributária absoluta. Regra não retroativa. Instrumento de atuação do Estado na área da previdência social. Obediência aos princípios da solidariedade e do equilíbrio financeiro e atuarial, bem como aos objetivos constitucionais de universalidade, equidade na forma de participação no custeio e diversidade da base de financiamento. Ação julgada improcedente em relação ao art. $4^{\circ}$, caput, da 
EC $n^{\circ}$ 41/2003. Votos vencidos. Aplicação dos arts. 149, caput, 150, I e III, 194, 195, caput, II e $\$ 6^{\circ}$, e 201, caput, da CF. Não é inconstitucional o art. $4^{\circ}$, caput, da Emenda Constitucional no 41, de 19 de dezembro de 2003, que instituiu contribuição previdenciária sobre os proventos de aposentadoria e as pensões dos servidores públicos da União, dos Estados, do Distrito Federal e dos Municípios, incluídas suas autarquias e fundações.

3. Inconstitucionalidade. Ação direta. Emenda Constitucional (EC $\mathbf{n}^{0}$ 41/2003, art. $4^{\circ}$, § único, I e II). Servidor público. Vencimentos. Proventos de aposentadoria e pensões. Sujeição à incidência de contribuição previdenciária. Bases de cálculo diferenciadas. Arbitrariedade. Tratamento discriminatório entre servidores e pensionistas da União, de um lado, e servidores e pensionistas dos Estados, do Distrito Federal e dos Municípios, de outro. Ofensa ao princípio constitucional da isonomia tributária, que é particularização do princípio fundamental da igualdade. Ação julgada procedente para declarar inconstitucionais as expressões "cinquenta por cento do" e "sessenta por cento do", constante do ar. $4^{0}$, § único, I e II, da EC n ${ }^{\circ} 41 / 2003$. Aplicação dos arts. $145, \S 1^{\circ}$, e 150, II, cc. Art. $5^{\circ}$, caput e $\S$ $1^{\circ}$, e $60, \S 4^{\circ}, I V$, da CF, com restabelecimento do caráter geral da regra do art. 40, $\$ 18$. São inconstitucionais as expressões "cinquenta por cento do" e "sessenta por cento do", constantes do $\S$ único, incisos I e II, do art. $4^{\circ}$ da Emenda Constitucional $\mathrm{n}^{\circ} 41$, de 19 de dezembro de 2003, e tal pronúncia restabelece o caráter geral da regra do art. $40, \S 18$, da Constituição da República, com a redação dada por essa mesma Emenda.

(grifos do texto original)

A ADIN 3.105-8 foi proposta pela Associação Nacional dos Membros do Ministério Público - CONAMP, a fim de ver declarada a inconstitucionalidade do artigo $4^{\circ}$ da Emenda Constitucional $n^{\circ} 41$ que estabeleceu a contribuição dos servidores inativos e pensionistas da União, Estados, Distrito Federal e Municípios, incluídas suas autarquias e fundações.

Por maioria de votos, a Corte Suprema reconheceu a constitucionalidade da exação instituída pelo caput do artigo $4^{\circ}$ e a inconstitucionalidade das expressões 'cinquenta por cento do’ e ‘sessenta por cento do’ constantes dos incisos I e II do parágrafo único.

Não se pretende, aqui, trazer a cabo todas as discussões ocorridas no julgamento, mesmo porque vários foram os pontos abordados.

Serão objeto de análise os votos apresentados pela Relatora originária, Ministra Ellen Gracie, não acolhidos pelos seus pares, e pelo Ministro Nelson Jobim, que acompanhou o Ministro Cesar Peluso, mas que trouxeram argumentos interessantes acerca da solidariedade e do equilíbrio financeiro e atuarial.

No voto apresentado pela Ministra Ellen Gracie, é transcrita a Exposição de Motivos que acompanhou o projeto da Emenda 41, verbis:

(..)

66. Inúmeras são as razões que determinam a adoção de tal medida, cabendo destacar o fato de a Previdência Social ter, essencialmente, um caráter solidário, exigindo, em razão dessa especificidade, que todos aqueles que fazem parte do 
sistema sejam chamados a contribuir para a cobertura do vultoso desequilíbrio financeiro hoje existente, principalmente pelo fato de muitos dos atuais inativos não terem contribuído, durante muito tempo, com alíquotas módicas, incidentes sobre o vencimento e não sobre a totalidade da remuneração, e apenas para as pensões, e, em muitos casos, também para o custeio da assistência médica (que é um benefício da seguridade social e não previdenciário).

(...)

70. Essas são as razões que fundamentam a instituição de contribuição previdenciária sobre os proventos dos atuais aposentados e pensionistas ou ainda daqueles que vierem a se aposentar. Além de corrigir distorções históricas, as tentativas de saneamento do elevado e crescente desequilíbrio financeiro dos regimes próprios serão reforçadas com a contribuição dos inativos, proporcionando a igualdade, não só em relação aos direitos dos atuais servidores, mas também em relação às obrigações.

\section{Destaca Sua Excelência que:}

Dessa leitura, verifica-se que, com a finalidade de alcançar o saneamento das finanças da previdência social, aposentados foram "reinstalados" na condição de contribuintes do sistema e pensionistas - que, estes, nunca estiveram na situação de contribuintes, passaram a sê-lo.

O equívoco em que, a meu sentir, incorrem os defensores da alteração introduzida pelo artigo ora em exame consiste em confundir sistemas diversos, de um lado o sistema estatutário a que se submetem os servidores públicos ao longo de sua vida funcional; de outro, o sistema previdenciário para o qual contribuem eles, quando em atividade e ao qual são agregados, quando ingressam na inatividade, passando a perceber não mais vencimentos, mas proventos, desligados que estão, para todos os efeitos, do serviço público.

Essa confusão de conceitos levou à presente tentativa de fazer com que os aposentados e pensionistas paguem retroativamente pelos benefícios que já auferem e que lhes foram regularmente deferidos, na forma da lei vigente ao tempo da inativação ou do óbito do servidor.

(...)

A emenda $n^{o} 41 / 03$, em seu art. $4^{\circ}$, portanto, quebra o sinalagma da relação jurídica previdenciária, forçando aposentados e pensionistas a efetuarem verdadeira "doação" de parte de seus proventos em nome do princípio da solidariedade intergeracional que, embora respeitável, nem por isso faz tábula rasa de outros princípios de igual dignidade constitucional, como a garantia contra a bitributação $(\mathrm{CF}$, art. 154, I) e o princípio do não confisco $(\mathrm{CF}$, art. 150, IV).

Com relação à instituição da contribuição para a preservação do equilíbrio financeiro e atuarial, a Ministra Ellen Gracie reproduz textualmente a indagação formulada pelo Vice-Procurador-Geral da República, Dr. Antonio Fernando Barros e Silva de Souza em seu parecer:

Qual o benefício futuro a que terá direito o aposentado ou pensionista que recolher a contribuição nos moldes estatuídos pelo art. $4^{\circ}$, da EC no 41/03? Não há resposta para a pergunta, o que corrobora o entendimento de que o legislador reformador criou tributo sem causa. 
Embora tenha restado vencida, a então Relatora adotou fundamentação que vai ao encontro dos parâmetros estabelecidos pela Constituição Federal para o Regime Próprio de Previdência Social.

A alteração do texto constitucional por obra do Poder reformador não tem o condão de atingir cláusulas pétreas. A existência de descalabros nos benefícios pagos aos servidores públicos inativos não pode ser resolvida a um toque de caixa, mediante a criação - ainda que pela via constitucional - de nova contribuição, por afronta ao direito adquirido e ao ato jurídico perfeito. Fere, ainda, o princípio da solidariedade, o princípio da isonomia e o princípio da causa suficiente (artigo 195, $\S 5^{\circ}$ da CFR), além de importar em retrocesso social.

$\mathrm{Na}$ outra ponta, defendendo entendimento diametralmente oposto, o Ministro Nelson Jobim destaca em seu voto que:

Há um problema, meus caros Colegas, sobre essa questão do equilíbrio atuarial, pois ele não tem nada a ver com a relação entre pagar e ter que receber. Ele é um conceito que vem da matemática atuarial - é bom deixar bem explicitada neste ponto - porque a atuária se refere a uma parte específica, ou estatística, que investiga problemas relacionados com cálculo de seguros, à probabilidade de eventos, à avaliação de riscos, à fixação de prêmios e à análise de mercado econômico para o estabelecimento de planos e políticas de investimento. A ideia do equilíbrio atuarial determina que o sistema previdenciário como um todo deve ter viabilidade econômico-financeira para o futuro e no futuro. Portanto, o equilíbrio atuarial não remete à noção de direitos e deveres individuais e, assim, não significa que toda contribuição deve ter uma causa eficiente, como se pretendeu - por isso, não pode ser levantado para justificar a suposta necessidade de causa para a alteração do regime.

A visão que prepondera no equilíbrio atuarial não é a individual, ou seja, o direito individual de receber aquilo que pagou, mas a do sistema como um todo e a sua necessidade de ser autossuficiente, de ser viável financeiramente. Equilíbrio atuarial é a necessidade de existir equivalência entre o ativo líquido do sistema e a sua reserva matemática, na linguagem dos atuários. Essa reserva significa a diferença entre as obrigações do plano para com os seus segurados, isto é, o valor atual dos benefícios futuros ou custo previdenciário - trazem-se os benefícios futuros, chamados custos previdenciários, para o momento atual - e as obrigações dos segurados para com o plano, o valor atual das contribuições.

Se a previsão atual de arrecadação futura é maior do que a previsão atual do pagamento de benefícios futuros, o sistema reflete superávit. Se, ao contrário, a previsão atual de arrecadação futura é menor do que a previsão atual de pagamento de benefícios futuros - essa diferença não se compensa com o patrimônio líquido atual do sistema -, o sistema está com déficit. É isto que significa o princípio do equilíbrio atuarial: um cálculo matemático com regras de probabilidade, ou seja, uma especialidade da matemática que trabalha exatamente com as ações de futuro, absolutamente nada a ver com as relações entre haver pago e ter direito a receber. Se fosse verdadeira a tese à qual me referi, teríamos a impossibilidade total de resolver as questões deficitárias do sistema, porque se tivéssemos que ter, a todo aumento ou criação de contribuições e tributo, um benefício subsequente, é evidente que não teríamos, em hipótese alguma, a possibilidade de trabalhar nesse sentido. (...). 
Com a devida vênia, entendemos que as razões adotadas pelo Eminente Ministro Nelson Jobim são todas de ordem econômica e voltadas para resolver problemas de natureza fundamentalmente econômica, essência que não caracteriza o núcleo do direito fundamental à previdência social.

A viabilidade financeira do sistema é necessária e desejável, mas ela não pode ser alcançada com o atropelamento dos direitos e garantias assegurados na Constituição. Entre o valor humano e a medida econômica, a balança só pode pender para aquele.

Infelizmente, na hipótese específica, não foi o que ocorreu.

\subsubsection{Omissão legislativa - Regime próprio de Previdência Social: serviço público exercido em condições penosas, insalubres ou perigosas}

O artigo 40, inciso III, da Constituição Federal, em sua redação originária, disciplinava as formas de aposentadoria voluntária do servidor público (por tempo de serviço - integral ou proporcional - e por idade). Constava de seu $\S 1^{\text {o }}$ que "lei complementar poderá estabelecer exceções ao disposto no inciso III, 'a' e 'c',252, no caso de atividades consideradas penosas, insalubres ou perigosas.

O dispositivo não foi regulamentado por lei complementar.

Recebeu então nova redação, especialmente por força das Emendas Constitucionais ns. $41 / 2003$ e $47 / 2005$, e o seu atual $\S 4^{\circ}$, inciso III, assegura ao servidor público o direito de computar o período trabalhado em condições especiais, nos termos definidos em lei complementar. $^{253}$

Decorridos mais de 21 (vinte e um) anos da promulgação da Constituição de 1988, ainda hoje não foi editada a necessária lei complementar disciplinando o trabalho exercido em condições especiais por funcionário público.

Temos aqui um caso típico de inconstitucionalidade por omissão (total) do legislador infraconstitucional, não obstante tal direito fundamental previdenciário estar gravado de forma expressa no texto constitucional.

O Poder Judiciário foi acionado, via mandado de injunção, a suprir a lacuna do legislador.

\footnotetext{
${ }^{252}$ A alínea $a$ trata da aposentadoria integral e a alínea $c$ da aposentadoria proporcional.

${ }^{253}$ Ressalte-se que já constava do texto originário o direito ao reconhecimento dos períodos laborados em condições penosas, insalubres ou perigosas, a ser regulamentado por lei complementar (artigo $40, \S 1^{\circ} \mathrm{CFR}$ ).
} 
O mandado de injunção $\mathrm{n}^{\circ}$ 721-8/DF foi proposto por uma servidora pública federal que exerce a função de auxiliar de enfermagem, alegando que no exercício de suas atividades está em constante exposição a agentes nocivos à saúde, pois mantém contato direto com portadores de moléstias infectocontagiosas humanas e materiais e objetos contaminados.

Alterando radicalmente a postura conservadora que até então lhe era característica, o Supremo Tribunal Federal, seguindo a trilha do julgamento proferido no Mandado de Injunção $n^{\circ}$ 712-8/PA (cujo objeto é a regulamentação da greve do servidor público), determinou regra específica a ser aplicada no caso concreto (aplicação das regras vigentes no Regime Geral de Previdência Social), ao invés de simplesmente declarar a mora do Poder Legislativo.

Merecem ser transcritos alguns trechos da decisão relatada pelo Ministro Marco Aurélio e publicada no DJ de 30/11/2007, Ementário n 2301-1, que bem demonstram a virada do posicionamento da Corte Suprema, verbis:

(...)

Assento, por isso, a adequação da medida intentada. Passados mais de quinze anos da vigência da Carta, permanece-se com o direito latente, sem ter-se base para o exercício. Cumpre, então, acolher o pedido formulado, pacífica a situação da impetrante. Cabe ao Supremo, porque autorizado pela Carta da República a fazê-lo, estabelecer para o caso concreto e de forma temporária, até a vinda da lei complementar prevista, as balizas do exercício do direito assegurado constitucionalmente.

O instrumental previsto na Lei Maior, em decorrência de reclamações, consideradas as Constituições anteriores, nas quais direitos dependentes de regulamentação não eram passíveis de ser acionados, tem natureza mandamental e não simplesmente declaratória, no sentido de inércia legislativa. Revela-se próprio, ao processo subjetivo e não ao objetivo, descabendo confundi-lo com ação direta de inconstitucionalidade por omissão, cujo rol de legitimados é escrito e está na Carta da República. Alias, há de se conjugar o inciso LXXI do artigo $5^{\circ}$ da Constituição Federal com o $\S 1^{\circ}$ do citado artigo, a dispor que as normas definidoras dos direitos e garantias fundamentais constantes da Constituição têm aplicação imediata. Indubitavelmente, buscou-se, com a inserção do mandado de injunção, no cenário jurídico-constitucional, tornar concreta, tornar viva a Lei Maior, presentes direitos, liberdades e prerrogativas inerentes à nacionalidade, à soberania e à cidadania. Não há se confundir a atuação no julgamento do mandado de injunção com atividade do Legislativo. Em síntese, ao agir, o Judiciário não lança, na ordem jurídica, preceito abstrato. Não, o que se tem, em termos de prestação jurisdicional, é a viabilização, no caso concreto, do exercício do direito, do exercício da liberdade constitucional, das prerrogativas ligadas a nacionalidade, soberania e cidadania.

$\mathrm{O}$ pronunciamento judicial faz lei entre as partes, como qualquer pronunciamento em processo subjetivo, ficando, até mesmo, sujeito a uma condição retroativa, ou seja, ao suprimento da lacuna regulamentadora por quem de direito, Poder Legislativo.

É tempo de se refletir sobre a timidez inicial do Supremo quanto ao alcance do mandado de injunção, ao excesso de zelo, tendo em vista a separação e harmonia entre os Poderes. É tempo de se perceber a frustração gerada pela postura inicial, 
transformando o mandado de injunção em ação simplesmente declaratória do ato omissivo, resultando em algo que não interessa, em si, no tocante à prestação jurisdicional, tal como consta no inciso LXXI do artigo $5^{\circ}$ da Constituição Federal, ao cidadão.

Impetra-se este mandado de injunção não para lograr-se simples certidão de omissão do Poder incumbido de regulamentar o direito a liberdades constitucionais, a prerrogativas inerentes à nacionalidade, à soberania e à cidadania. Busca-se o Judiciário na crença de lograr a supremacia da Lei Fundamental, a prestação jurisdicional que afaste as nefastas consequências da inércia do legislador. Conclamo, por isso, o Supremo, na composição atual, a rever a óptica inicialmente formalizada, entendendo que, mesmo assim, ficará aquém da atuação dos tribunais do trabalho, no que, nos dissídios coletivos, a eles a Carta reserva, até mesmo, a atuação legiferante, desde que, consoante prevê o $\S 2^{\circ}$ do artigo 114 da Constituição Federal, sejam respeitadas as disposições mínimas legais de proteção ao trabalho. Está-se diante de situação concreta em que o Diploma Maior recepciona, mesmo assim de forma mitigada, em se tratando apenas do caso vertente, a separação dos Poderes que nos vem de Montesquieu. Tenha-se presente a frustração gerada pelo alcance emprestado pelo Supremo ao mandado de injunção. Embora sejam tantos os preceitos da Constituição de 1988, apesar de passados dezesseis anos, ainda na dependência de regulamentação, mesmo assim não se chegou à casa do milhar na impetração dos mandados de injunção.

(...)"

Após a publicação da decisão proferida no MI 721-8, inúmeras outras ações desta natureza foram ajuizadas, de tal forma que os Ministros deliberaram que os novos casos poderão ser decididos monocraticamente por cada Relator, sem necessidade de levar o feito a Plenário.

Em consulta efetuada no site do Supremo Tribunal Federal

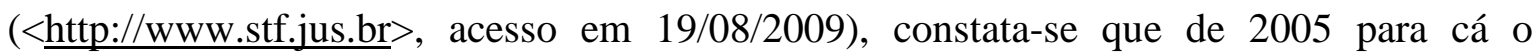
número de mandados de injunção propostos tem aumentado de forma progressiva.

No ano de 2005, foram ajuizados 17; em 2006, também 17; em 2007, o número subiu para 49; em 2008, 140 mandados de injunção foram propostos e de 01/01/2009 a 23/07/2009, 662 já haviam sido protocolizados.

Embora ainda não tenha atingido a casa do milhar, apesar de transcorridos mais de vinte anos desde a promulgação da Constituição de 1988, o fato é que tem crescido consideravelmente a utilização deste instrumento processual.

De um lado, trata-se de fenômeno positivo, pois demonstra a confiança no Poder Judiciário como órgão protetor dos direitos fundamentais, cumpridor, portanto, de sua missão constitucional. E, sobretudo, indica o reconhecimento, pela Corte Suprema, do caráter subjetivo do direito fundamental à previdência social.

De outro lado, demonstra uma apatia dos Poderes Executivo e Legislativo (sobretudo) no exercício de suas funções típicas, fato que não colabora para a evolução do Estado Democrático de Direito. 


\subsection{O Poder Judiciário e as ações coletivas em questões previdenciárias}

Salientamos no Capítulo 2 a importância da discussão das políticas públicas previdenciárias por meio de ações coletivas, quer em razão do julgamento equânime a alcançar todos os que se encontram na mesma situação, quer em razão dos custos gerados para as partes e para o Poder Judiciário para o processamento de milhares de ações individuais tendo por objeto a mesma questão jurídica.

A fim de traçar um panorama sobre a utilização das ações coletivas para a defesa do direito fundamental à previdência, delimitamos o estudo às ações civis públicas interpostas pelo Ministério Público, quer por serem as mais numerosas, quer pela maior confiabilidade dos meios de pesquisa.

Em consulta de jurisprudência efetuada no site do Conselho da Justiça Federal ${ }^{254}$, constatou-se o ajuizamento por parte do Ministério Público de inúmeras ações tratando de questões previdenciárias.

Parte considerável dos juízes de primeiro grau e dos Tribunais Regionais Federais tem admitido a legitimidade ativa do Parquet, como demonstram as seguintes ementas:

PROCESSO CIVIL. PREVIDENCIÁRIO. TRIBUTÁRIO. AÇÃO CIVIL PÚBLICA. MINISTÉRIO PÚBLICO. PREVIDENCIÁRIO. LEGITIMIDADE AD CAUSAM. INTERESSE PROCESSUAL. POSSIBILIDADE JURÍDICA DO PEDIDO. COMPETÊNCIA. EFICÁCIA DA SENTENÇA. COISA JULGADA. ISONOMIA. BENEFÍCIOS. SALÁRIO MÍNIMO. JUNHO DE 1989. NCZ 120,00. IMPOSTO SOBRE A RENDA. RESPONSABILIDADE CIVIL. MORA. CORREÇÃO MONETÁRIA.

(...)

II - Há legitimidade ad causam do Ministério Público tendo em vista a natureza homogênea do direito, o qual tem origem comum. Não é razoável conferir interpretação restritiva às normas infraconstitucionais, para o efeito de excluir a legitimidade da Instituição, tendo em vista que a Constituição outorgou-lhe amplos poderes (de provocação do Poder Judiciário), inter alia, para a proteção da ordem jurídica e do regime democrático. Pode a norma legal conferir legitimidade extraordinária, mesmo para hipóteses não previstas na Constituição. Ademais, não se deve confundir disponibilidade com faculdade de não exercício: os benefícios previdenciários, como tais, não são disponíveis, dado que a vontade do titular intercede tão só para aperfeiçoar a fattispecie, cujos efeitos são predeterminados pela ordem e infensos à vontade do segurado e da Autarquia. Tendo o Código de Defesa do Consumidor, em combinação com a Lei da Ação Civil Pública, ampliado a legitimidade do Ministério Público, não se sustenta, neste caso, a alegação de ilegitimidade ad causam do Ministério Público Federal. (...)

(TRF $3^{\text {a }}$ Região, AC 95.03.074603-5/SP, Relator Juiz Federal André Nekatschalow, DJU 21/05/2002).

${ }^{254}$ Disponível na página <http://www.cjf.jus.br> , acesso em 01/09/2009. 
PREVIDENCIÁRIO. PROCESSUAL CIVIL. AGRAVO REGIMENTAL. ANTECIPAÇÃO DA TUTELA. AÇÃO CIVIL PÚBLICA. LEGITIMIDADE DO MINISTÉRIO PÚBLICO FEDERAL. ÍNDICE DE ATUALIZAÇÃO MONETÁRIA. CONDENAÇÃO EM HONORÁRIOS.

1. Este Tribunal vem reconhecendo a legitimidade ativa do Ministério Público Federal para propor ação civil pública na defesa dos direitos individuais homogêneos em matéria previdenciária, à luz do entendimento atualizado do Supremo Tribunal Federal.

(...)

(TRF 4 ${ }^{\mathrm{a}}$ Região, AR 2008.04.00023517-8/RS, Terceira Seção, Relator Desembargador Federal Ricardo Teixeira do Valle Pereira, D.E 15/12/2008).

PROCESSUAL CIVIL. AÇÃO CIVIL PÚBLICA. EXTINÇÃO SEM JULGAMENTO DO MÉRITO POR ILEGITIMIDADE ATIVA. INCONSTITUCIONALIDADE DA LEI $\mathrm{N}^{\circ}$ 9.528/97, NA PARTE QUE ALTEROU O ART. 74, DA LEI $\mathrm{N}^{\circ}$ 8.213/91. PENSÃO POR MORTE. MOMENTO EM QUE SE TORNA DEVIDA. DATA DO ÓBITO/DATA DO REQUERIMENTO ADMINISTRATIVO. LEGITIMIDADE ATIVA DO MINISTÉRIO PÚBLICO. PROSSEGUIMENTO DO FEITO.

1. Ação civil pública proposta pelo Ministério Público Federal, visando ao reconhecimento da inconstitucionalidade das alterações introduzidas pela Lei ${ }^{\circ}$ 9.528/97 no art. 74, da Lei $\mathrm{n}^{\circ}$ 8.213/91 e a condenação do INSS na concessão dos benefícios de pensão por morte aos dependentes de segurados, que vierem a falecer, a contar do óbito, independentemente da data dos requerimentos administrativos. Sentença que extinguiu o feito sem julgamento do mérito, por entender caracterizada a ilegitimidade ativa do autor. Discussão que se encerra, sobretudo, na legitimidade do Parquet para o ajuizamento de ações civis públicas concernentes a benefícios previdenciários.

2. (...).

3. Em que pesem as notáveis considerações deduzidas em precedentes do Superior Tribunal de Justiça (RESP 506.457, AGRESP 423.928, RESP 419.187), é de se reconhecer a legitimidade do Ministério Público. O objeto da ação (definição do momento a partir do qual será devida a pensão por morte), ao lado da dimensão subjetiva (quantidade de sujeitos de direito envolvidos) atingida pelos efeitos da Lei $\mathrm{n}^{\circ}$ 9.528/97, confirmam a legitimidade ministerial para o seu ajuizamento. Interpretação sistemática dos arts. 127 e 129, III e IX, da CF/88, art. 25, IV, "a", da Lei no 8.625/93, e arts. 5, I, II, "d", e III, "e", e 6º, VI, "a" à "d", e XII, da LC no 75/93.

4. A natureza das atribuições determinadas como de competência do Órgão Ministerial, a dimensão de sua responsabilidade, a pluralidade de categorias e temáticas em relação às quais detém incumbências de particular seriedade, $o$ poder investigativo, fiscalizador e determinante de que foi dotado esse agente constitucionalmente qualificado pela sua essencialidade à função jurisdicional do Estado - impõem seja admitido, com largueza, o exercício de ações coletivas pelo Ministério Público, não sendo aceitáveis, em sentido oposto, interpretações restritivas ou inibidoras.

5. Ao Ministério Público se confere o dever de salvaguarda, não apenas dos direitos ditos indisponíveis, mas também dos interesses socialmente relevantes, independentemente da indisponibilidade que os grave ou não, ou seja, das pretensões que se reconheçam com repercussão ou reflexão na coletividade considerada em conjunto. Assim, nesse contexto, não se pode permitir a atuação do Ministério Público na proteção de interesses marcados pela individualidade, com exercitação confinada no correspondente titular, sem reverberação no campo do social. Contudo, de outro lado, ao Ministério Público não se pode deixar de reconhecer a sua responsabilidade na promoção de direitos e reivindicações que, embora com titulares identificados ou identificáveis, têm acentuada conotação social, seja pela natureza do objeto pretendido, seja pela qualidade distintiva de certa categoria, cujas necessidades sejam discernidas pela própria sociedade como precisões de índole coletiva ou arrimadas em cuidado 
especial restaurador de equilíbrio indispensável diante das dificuldades vivenciadas em relação à própria inserção social.

6. A norma legal que instituiu a ação civil pública - Lei $n^{\circ} 7.347 / 85$ - nasceu como "lei dos interesses difusos". Posteriormente, em decorrência especialmente do alargamento providenciado pelo Código de Defesa do Consumidor (Lei $\mathrm{n}^{\circ}$ 8.078, de 11.09.1990), a ação civil pública passou a ser admitida para fins de proteção de interesses difusos, coletivos e individuais homogêneos, denominados, genericamente, de interesses transindividuais. A doutrina tem se referido ao fato de que promoção de direitos individuais homogêneos ("acidentalmente coletivos") teria cabimento apenas quando se tratasse de meio ambiente, consumidor e patrimônio artístico, estético, histórico, turístico e paisagístico, não havendo, de outro lado, limitação material, quando se cuidasse de direitos coletivos e difusos ("essencialmente coletivos"). É de se ressaltar, entretanto, que, a despeito dessa diferenciação, tem-se agasalhado, em outras oportunidades, uma compreensão mais ampliada dos direitos individuais homogêneos, reputados espécies do gênero coletivo, aptos a serem defendidos através da propositura da ação civil pública, especialmente quando ela é manuseada pelo Ministério Público. Passou-se a se conceber a promoção da ação coletiva em defesa de direitos individuais homogêneos quando configurado manifesto interesse social, compatível com a finalidade da instituição ministerial. 7. "In casu", estão em litígio direitos/interesses que se pode qualificar de individuais homogêneos. O Ministério Público postula o reconhecimento da inconstitucionalidade da Lei $\mathrm{n}^{\circ}$ 9.528/97 que, ao alterar o art. 74, da Lei $\mathrm{n}^{\circ}$ $8.213 / 91$, prescreveu o direito ao benefício previdenciário pensão por morte a partir do óbito (quando o correspondente requerimento der entrada dentro de trinta dias do falecimento) ou a contar o requerimento administrativo (quando formulado extemporaneamente aos trinta dias). Está em discussão o relevante direito social à previdência social, constitucionalmente concebido, ex vi do art. $7^{\circ}$, caput, da $\mathrm{CF} / 88$, entendendo-se por direito social à previdência social também o direito à percepção dos benefícios, de conformidade com os ditames legais e constitucionais, de forma capaz a garantir a satisfação de todas as necessidades de subsistência que se associam a esses valores. Os direitos individuais homogêneos "se caracterizam por serem um feixe de direitos subjetivos individuais, marcado pela nota de divisibilidade, de que é titular uma comunidade de pessoas indeterminadas mas determináveis, cuja origem está em questões comuns de fato ou de direito" (Gidi). No caso concreto, têm-se direitos individuais homogêneos, na medida em que, embora atribuídos a cada segurado/beneficiário, segundo a sua situação particularizada, estão agregados as particularidades que individualizam são juridicamente irrelevantes, manifestando-se a divisibilidade apenas no momento da execução do provimento judicial coletivo - por uma origem comum (resultando na homogeneidade), qual seja a percepção de benefício previdenciário e a definição do momento a partir do qual será devida a pensão por morte.

8. Não se mostra conforme aos princípios da razoabilidade, da economia processual e também da isonomia entender pela ilegitimidade do Ministério Público, impelindo todos os segurados/beneficiários prejudicados a ajuizarem ações individuais, gerando acúmulo de demandas que, pela identidade de discussão, poderiam e deveriam ter a mesma solução.

9. Precedentes dos Tribunais Regionais Federais (inclusive da $4^{\mathrm{a}}$ Região, em feito análogo - Sexta Turma, AC 426674, j. em 22/10/2002, publ. em DJU de 06/11/2002, Relator Juiz Guilherme Pinho Machado) e do Superior Tribunal de Justiça (Quinta Turma, RESP 413986/PR, Rel. Min. José Arnaldo da Fonseca): "O Ministério Público está legitimado a defender direitos individuais homogêneos quando tais direitos têm repercussão no interesse público"./ "O exercício das ações coletivas pelo Ministério Público deve ser admitido com largueza. Em verdade a ação coletiva, ao tempo em que propicia solução uniforme para todos os envolvidos no problema, livra o Poder Judiciário da maior praga que o aflige, a repetição de processos idênticos". 
10. Pelo provimento da remessa oficial e da apelação, para reconhecer a legitimidade ativa do Ministério Público e determinar o prosseguimento do feito."

(TRF 5a Região, Apelação Cível 322075, Relator Desembargador Federal Francisco Cavalcanti, DJ de 09/06/2004).

O Superior Tribunal de Justiça, por sua vez, tem reiteradamente sustentado a ilegitimidade ativa do Ministério Público para a propositura de ações que têm por objeto a discussão de questões previdenciárias, ao fundamento de que cuidam de interesses disponíveis, verbis:

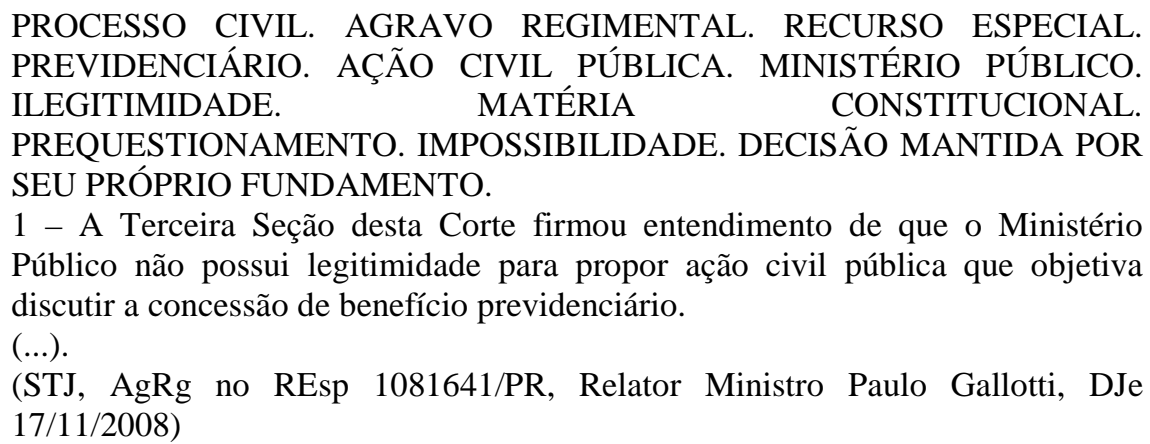

AGRAVO REGIMENTAL EM RECURSO ESPECIAL. AÇÃO CIVIL PÚBLICA. REVISÃO DE BENEFÍCIO PREVIDENCIÁRIO. DIREITOS DISPONÍVEIS. MINISTÉRIO PÚBLICO. ILEGITIMIDADE ATIVA $A D$ CAUSAM. DECISÃO MANTIDA.

1. De acordo com o entendimento firmado pela Terceira Seção, o Ministério Público não possui legitimidade para propor ação civil pública objetivando a revisão da renda mensal de benefícios previdenciários, porquanto estes encontram-se na esfera do interesse patrimonial disponível.

2. Agravo regimental improvido.

(STJ, AgRg no REsp 98905/RS, Relator Ministro Jorge Mussi, DJe 08/09/2008).

A interpretação restritiva que vem sendo conferida pelo Superior Tribunal de Justiça fere, a nosso ver, a norma constitucional que assegura a defesa dos direitos individuais homogêneos pelo Ministério Público e acaba por esvaziar, ainda que de forma indireta, o conteúdo do direito fundamental à previdência social por impedir que a sua fruição plena seja feita por todos os beneficiários do sistema, independentemente das condições financeiras individuais.

A análise sistemática do ordenamento jurídico (artigo $1^{\circ}$, IV, da Lei $n^{\circ} 7.347 / 85$, com a redação dada pela Lei $n^{\circ} 8.078 / 90$, artigo 81 da Lei $n^{\circ} 8.078 / 90^{255}$ e artigos 127 ,

\footnotetext{
${ }^{255}$ O parágrafo único do artigo 81 da Lei $n^{\circ} 8.078 / 90$ define os interesses ou direitos coletivos que podem ser defendidos de forma coletiva, verbis:

"Art. 81. A defesa dos interesses e direitos dos consumidores e das vítimas poderá ser exercida em juízo individualmente, ou a título coletivo.

Parágrafo único. A defesa coletiva será exercida quando se tratar de:
} 
caput, e artigo 129, II e III, da Constituição Federal) não permite seja afastada da competência do Ministério Público a legitimação ativa para a propositura de ações envolvendo direitos individuais homogêneos, espécies de direitos coletivos lato sensu.

O caminho aberto pelo ordenamento para a utilização das ações coletivas foi uma grande conquista da sociedade brasileira, pois a nossa tradição liberal formata o Direito sob a ótica do indivíduo. O avanço iniciado em 1985, com a edição da Lei no 7.347 (Lei da Ação Civil Pública) e consolidado em 1988, com a Constituição Federal, não pode ser minimizado por interpretações restritivas e em desacordo com as demais normas constitucionais.

De acordo com o Professor Marcus Orione Gonçalves Correia,

\begin{abstract}
a natureza dos interesses defendidos nas ações civis públicas (...) faz com que tenhamos a nítida certeza de que esta ação constitucional é de vital relevância para a preservação do Estado democrático de direito. A possibilidade de que no seu bojo contenha a preservação de direitos sociais, por sua vez, somente faz com que fiquemos certos da sua função estratégica no mundo moderno. Portanto, através da implementação da utilização mais efetiva desta modalidade de ação, estar-se-á prestigiando mais uma vez o trinômio poder constitucional de ação, direitos sociais e Estado democrático de direito. ${ }^{256}$
\end{abstract}

\title{
3.3. Algumas conclusões
}

Este pequeno repertório de decisões nos mostra o quanto o Poder Judiciário tem sido acionado para resolver as mais diversas questões envolvendo matéria previdenciária, especialmente a partir da Constituição de 1988.

Naqueles primeiros tempos, parte expressiva dos órgãos julgadores mostrava empenho na busca de uma interpretação constitucional verdadeiramente social, com os olhos voltados à concretização do direito fundamental à previdência social.

Em tese de doutorado defendida perante esta Faculdade, em 1996, o Professor Marcus Orione Gonçalves Correia, após analisar a jurisprudência previdenciária formada especialmente a partir da Carta constitucional de 1988, alcançou a conclusão de que o Poder Judiciário estava tratando com bastante destaque a questão previdenciária, buscando a efetiva entrega da justiça material, tendo como objetivos (ainda que não manifestamente

I - interesses ou direitos difusos, assim entendidos, para efeitos deste Código, os transindividuais, de natureza indivisível, de que sejam titulares pessoas indeterminadas e ligadas por circunstâncias de fato; II - interesses ou direitos coletivos, assim entendidos, para efeitos deste Código, os transindividuais de natureza indivisível, de que seja titular grupo, categoria ou classe de pessoas ligadas entre si ou com a parte contrária por uma relação jurídica base;

III - interesses ou direitos individuais homogêneos, assim entendidos os decorrentes de origem comum.”

${ }^{256}$ Op. cit., 2002, p. 116. 
declarados): a busca do bem-estar social (seja através de decisões individuais em favor dos segurados, seja através de opções pela integridade do sistema de seguridade social) e a preocupação com a real distribuição de renda (que deve nortear os rumos da Previdência Social). ${ }^{257}$ E tal era, efetivamente.

$\mathrm{O}$ argumento foi reforçado na sua tese de livre-docência, afirmando o eminente Professor que a evolução dos direitos sociais possibilitou que os juízes passassem a exercer uma nova posição na condução dos processos, muito mais dinâmica e criativa, embora não criadora de lei, tanto é assim que "a atuação do juiz no trato dos direitos sociais (direitos trabalhistas e previdenciários), ainda hoje, é bem mais ativa e participativa do que a que vem sendo desempenhada pelo juiz que lida com questões diversas de natureza civil, por exemplo."258

No entanto, da mesma forma que as inovações do texto constitucional foram cedendo vez a apelos de ordem econômica, assistindo-se mais e mais à redução do conteúdo do direito fundamental, também assim expressivo número de juízes parece ter sido seduzido pelos argumentos econômicos.

Sobretudo a partir da alteração do texto constitucional ocorrida em 1998, por força da Emenda $n^{\circ}$ 20, é possível divisar as decisões sobre questões previdenciárias em dois grupos: (i) as primeiras envolvendo, sobretudo, ações individuais, sem grande repercussão financeira; (ii) as segundas envolvendo ações individuais e coletivas, com forte repercussão financeira.

Tem-se a impressão de que primeiro se olham os efeitos financeiros da decisão, depois se busca o direito, vale dizer, o direito fundamental só é reconhecido se existir disponibilidade financeira para concretizá-lo, posição frontalmente contrária àquela que acreditamos ser a tônica do Estado Democrático de Direito e que permeia toda a Constituição Federal.

Em outras palavras, assistiu-se, por parte dos juízes, à imediata incorporação da lógica econômica, como premissa absoluta, a partir da qual os novos casos começaram a ser resolvidos.

A constitucionalização do equilíbrio financeiro e atuarial como princípio previdenciário específico acabou estabelecendo um único critério para o controle judicial das políticas públicas previdenciárias. Essencialmente, mais do que um princípio, o

\footnotetext{
${ }^{257}$ A jurisprudência e a promoção do bem-estar social em matéria previdenciária. Tese de Doutorado apresentada junto à Faculdade de Direito da Universidade de São Paulo, 1996. p. 312-313.

${ }^{258}$ CORREIA, Marcus Orione Gonçalves. Op. cit., 2002, p. 86.
} 
equilíbrio financeiro e atuarial tem sido utilizado, após a Emenda Constitucional $\mathrm{n}^{\mathrm{o}}$ 20/1998, como uma premissa absoluta a nortear o sistema previdenciário. Se antes era a solidariedade o vetor que direcionava a atuação dos Poderes públicos e estimulava o envolvimento da coletividade na busca do bem-estar, agora é a lógica economicista e individualista que sobrepaira.

Atendo-se especificamente ao conteúdo das decisões proferidas pelo Supremo Tribunal Federal, José Antonio Savaris identifica duas doutrinas distintas acerca do direito fundamental à Previdência Social, verbis:

\begin{abstract}
Uma primeira doutrina constituía a linha de interpretação da Suprema Corte orientada à efetivação dos princípios constitucionais de proteção social, forjada no ambiente de conquistas sociais que foram consagradas na Constituição da República de 1988. Essa doutrina progressista, especialmente após a densificação dos apelos econômicos de equilíbrio financeiro cristalizados na Lei n. 9.032/95 e na Emenda Constitucional n. 20/98, parece ter cedido espaço a uma outra concepção de proteção social, a qual jamais se pode dizer imune à atmosfera de austeridade que alcançou nosso país no início da década de noventa do século passado.

Em um tiro, a nova doutrina do Supremo Tribunal Federal é aquela que, expressa ou veladamente, se revela preocupada com o equilíbrio financeiro e atuarial entenda-se, eficiência econômica - da seguridade social. É como se o discurso utilizado para implementação das reformas restritivas se tornasse norma jurídica de mais alto quilate e fosse acriticamente reproduzido pela maioria dos atuais magistrados do STF. 259
\end{abstract}

Ousamos estender suas conclusões à porção maior do Judiciário brasileiro, embora ainda se notem alguns focos de resistência.

Devemos reconhecer que a tática utilizada pelos Poderes Executivo e Legislativo constitucionalização do equilíbrio financeiro e atuarial - teve enorme êxito na medida em que convenceu os operadores do Direito de que não era necessário proceder a mais nenhum tipo de ponderação, já que agora constava do texto constitucional a necessidade do equilíbrio financeiro e atuarial, a ser perseguido de forma inconteste.

Obviamente que ao lado da inserção do princípio no texto constitucional, procedeuse a uma profunda propaganda ideológica que enfatizava, com toque de terror, a necessidade imediata de redução de custos, colocando nos ombros da Previdência Social grande parte da culpa pelo caos.

E o discurso foi incorporado, sem grandes questionamentos.

A nós resta claro que em questões jurídicas envolvendo gastos públicos de monta ou que podem configurar precedentes com tais efeitos, o Poder Judiciário tem optado por

259 SAVARIS, José Antonio. O Judiciário e a Política de Retração Sistemática da Previdência Social no Brasil. In FAGNANI, Eduardo; HENRIQUE, Wilnês; LÚCIO, Clemente Ganz. Op. cit., p. 51. 
adotar soluções típicas da lógica econômica, não obstante sua missão precípua seja a guarda da Constituição Federal.

Se é possível esboçar alguma conclusão, após a análise dos casos selecionados, ousamos fazê-lo nos seguintes termos: no período imediatamente posterior à promulgação da Constituição Federal, as pessoas recorriam ao Judiciário para saber que direitos eram titulares, dentre os vários reconhecidos pelo legislador constituinte. No período posterior às Emendas restritivas, só lhes resta perguntar que direitos sobraram.

E, apesar de constatarmos um certo vacilo do Poder Judiciário após as mudanças ocorridas sobretudo a partir de 1988, mantemos a esperança de que ele não abandone a preservação da ordem jurídica em prol da supremacia da ordem econômica. A concretização dos direitos sociais é um dos fatores essenciais para a consolidação do Estado democrático de direito e o Judiciário é um forte aliado seu, impondo sempre que tal relação seja reavivada, pois sedimentada na própria Constituição.

O vazio que se pretende legar aos direitos sociais conspira contra os ideais básicos do Estado democrático. Herdamos a salutar sensação de que somente há democracia onde há justiça social. A nossa experimentação histórica não nos possibilita - ainda bem! - acreditar que a democracia tenha forças para fecundar onde não há proteção normativa daqueles que se encontram à margem das grandes decisões do processo econômico e social. Embora herdeiros desta experiência, vivenciamos a derrocada dos direitos sociais no contexto normativo da modernidade. No entanto, dentro da perspectiva deste estudo, devemos repudiar sempre tal postura, mormente quando atente contra diretrizes sociais postas constitucionalmente - entendidas estas como as regras oriundas do poder constituinte originário. ${ }^{260}$

${ }^{260}$ CORREIA, Marcus Orione Gonçalves. Op. cit., 2002, p. 45. 


\section{CONCLUSÃO}

Resta-nos aqui sistematizar as conclusões já alcançadas ao longo de cada capítulo.

Retomando sinteticamente a exposição, analisamos, no Capítulo 1, o tema políticas públicas. O ponto de partida foi sua abordagem interdisciplinar, demonstrando que sua exata compreensão só pode ser obtida através da conciliação das diversas contribuições prestadas por todas as disciplinas envolvidas.

As políticas públicas são decisões políticas, elaboradas no âmbito próprio e mediante a participação de vários órgãos, inclusive de representantes da coletividade a que se destinam. Uma vez formuladas, devem ser incorporadas pelo ordenamento jurídico.

A conformação à ordem jurídica, contudo, nem sempre é tão simples. Em alguns casos, a alteração é introduzida por meio da legislação infraconstitucional, por estar em conformidade com os postulados constitucionais. Em outros, no entanto, mostra-se necessária a modificação do texto constitucional, impondo a observância de duas condições: (i) a não violação das cláusulas pétreas estabelecidas no $\S 4^{\circ}$ do artigo 60 da Constituição Federal; e (ii) o processo legislativo de reforma constitucional.

De maneira geral e bastante resumida, as políticas públicas têm como objetivo principal concretizar os direitos fundamentais estabelecidos na Constituição Federal. Portanto, a primeira diferenciação que se faz necessária é entre o conceito de direitos fundamentais e o de políticas públicas.

Para os fins deste trabalho, optou-se pelo estudo das políticas públicas em sua dupla dimensão: como política de Estado e como políticas de Governo.

A primeira delas trata das opções políticas relacionadas à estrutura do Estado, dispondo sobre as formas de organização e funcionamento do aparelho estatal, os valores fundamentais positivados e as diretrizes que devem nortear a efetivação dos objetivos lançados. As políticas de Estado são, em suma, opções políticas que indicam e orientam o modelo de ação estatal a longo prazo, independentemente do programa de governo.

Embora geralmente as políticas de Estado se encontrem inscritas no texto constitucional, não é correto afirmar que se trata de políticas de Estado apenas e tão somente porque ali estão. Existem inúmeros dispositivos constitucionais que não guardam qualquer relação com tais diretrizes de atuação estatal, não traduzindo assim nenhuma opção política relativa a um valor fundamental ou à estrutura do Estado. De outro lado, é possível que algumas políticas de Estado delineadas na Constituição Federal sejam 
regulamentadas por lei (ordinária e complementar), que desta forma também se caracteriza como política de Estado, em conjunto com a diretriz constitucional.

Já a segunda dimensão contempla as opções políticas mais concretas e específicas, voltadas a resolver questões definidas, mediante a utilização de meios previamente estabelecidos e em espaço de tempo delimitado. Trata-se do sentido estrito da expressão políticas públicas, também denominadas políticas de Governo ou policies.

Num caso e noutro, o objetivo é o mesmo: a concretização do direito fundamental.

Buscamos apresentar um traçado do direito fundamental à previdência social no Brasil com o intuito de ressaltar o grande passo dado pela Constituição Federal de 1988 que, de forma inédita, alçou os direitos sociais à categoria de direitos fundamentais e os acobertou por cláusulas pétreas.

Em matéria previdenciária, o texto constitucional contém não apenas disposições relativas ao conteúdo do direito fundamental, como também as diretrizes a serem observadas na sua efetivação, diretrizes que aqui denominamos como política de Estado.

Daí se extrai que o conteúdo do direito fundamental, por nós identificado como o conjunto de normas que estabelecem as contingências acobertadas e os parâmetros que devem ser observados pelo legislador infraconstitucional na fixação do valor do benefício, está a salvo de qualquer alteração legislativa posterior, ainda que introduzida por meio de reforma constitucional. Já a política de Estado pode - e deve - ser alterada sempre que necessário, na medida em que reflete as opções políticas condizentes com as necessidades da coletividade e com os recursos disponíveis pelo ente estatal.

A Previdência Social, expressamente qualificada como direito fundamental e um dos pilares do sistema de Seguridade Social, foi uma das áreas que mais sofreu alterações, quer por meio da legislação infraconstitucional, quer por meio de reformas constitucionais, sobretudo nos anos de 1998 (Emenda n 20) e 2003 (Emenda nº 41).

Vimos que o desenho original inscrito na Carta de 1988 estabeleceu as bases para a construção de um Estado de Bem-Estar, seguindo rumo contrário ao tomado por diversos países. No entanto, antes mesmo da efetiva implantação de tal modelo de Estado, o país optou por aderir a alguns postulados neoliberais, promovendo a redução da atuação estatal na prestação de alguns serviços.

No âmbito da previdência, verificou-se uma forte atenuação do regime de repartição simples, fundado no princípio da solidariedade, acenando-se para a adoção do regime de capitalização e para a privatização, ao menos parcial, do sistema previdenciário. 
Atualmente, então, o que temos é uma Previdência Social mesclada por institutos característicos de um Estado de Bem-Estar Social e por institutos típicos do modelo neoliberal.

Se a tomada da decisão política ocorre em esfera diversa à do Direito, aos seus operadores compete preservar a ordem jurídica. Desta forma, a inclusão de postulados neoliberais, mesmo que fruto de opção política legítima, deve ser feita com observância das regras jurídicas.

Por expressa designação constitucional, foi conferido ao Poder Judiciário o dever de dizer o Direito, sempre que instado a tal. Ao Judiciário compete afirmar se a opção política pode ou não ser conformada pelo Direito e em que medida.

Recentemente, tivemos um exemplo bastante elucidativo demonstrando como a interação entre os Poderes ocorre na prática. Trata-se da instituição da contribuição social devida pelos servidores públicos inativos e pensionistas. Inicialmente veiculada por meio de lei ordinária (Lei $n^{\circ}$ 9.783/99), foi repugnada pelo Judiciário ao fundamento de que portava vício formal, já que o texto constitucional então vigente não comportava sua instituição. Atendendo às exigências contidas na decisão judicial (ADIN 2.010-2/DF), foi então proposta uma reforma de Emenda Constitucional que, uma vez aprovada (Emenda Constitucional $n^{\circ} 41 / 2003$ ), teve sua constitucionalidade atestada pelo Supremo Tribunal Federal (ADIN no 3.105 e ADIN 3.128).

Procuramos indicar, no Capítulo 2, os instrumentos postos à disposição dos beneficiários da Previdência Social (segurados e dependentes) para postular a concretização do direito fundamental de que são titulares, enfatizando as vantagens da utilização das ações coletivas para tais fins.

Também identificamos os instrumentos e as técnicas utilizados pelo Poder Judiciário para decidir os casos concretos. Adotamos, para tanto, o modelo proposto pelo Professor alemão Robert Alexy, que concebe as normas de direitos fundamentais como um sistema de regras e princípios. A opção se justifica com base na estrutura normativa adotada pela Constituição de 1988.

Vimos que os direitos fundamentais, embora acobertados por cláusulas pétreas, podem ser restringidos, já que se cuidam de duas coisas distintas: o direito e sua restrição.

O modelo de sopesamento fornecido por Alexy permite ao juiz que, caso a caso, estabeleça uma relação de precedência condicionada entre os princípios concorrentes, relação que indica, no caso concreto, em que condições um princípio prevalece sobre outro, precedência que pode se alterar se outra for a situação apresentada. 
Esta técnica permite compatibilizar, a nosso ver, as várias restrições introduzidas na legislação pátria e o texto original da Constituição, cabendo ao juiz decidir se, na hipótese sub judice, a aplicação da restrição encontra justificativa racional. Desta forma, é mediante o cotejo entre os princípios colidentes que o juiz deve indicar qual a regra válida no caso. Para tanto, deve se valer de todos os meios de prova possibilitados pela legislação e necessários à formação de seu convencimento.

Ao se pronunciar sobre os atos - e também sobre as omissões - praticados pelos Poderes Executivo e Legislativo, no exercício de suas atribuições típicas, especialmente em matéria de políticas públicas, o Poder Judiciário deve respeitar certas limitações, em respeito ao princípio da separação e harmonia entre os Poderes. Se o direito é fundamental, deve ser efetivado, impondo ao Poder Judiciário que realize sua missão constitucional, não se admitindo sua omissão.

É importante ressaltar que o Judiciário não cria políticas públicas, mesmo quando fornece uma solução no caso de omissão do poder competente. Trata-se de uma regra específica a resolver apenas e tão somente aquela hipótese. Por tal razão é que recomendamos que as discussões envolvendo as questões previdenciárias sejam veiculadas através de ações coletivas, pois a decisão ali proferida terá o condão de atingir todos os beneficiários que se encontram na mesma situação.

Em qualquer caso, quer quando o Judiciário se manifesta sobre uma política pública já existente, quer quando é instado a se pronunciar nos casos de omissão, não há formulação de política pública, mas apenas adequação dos atos praticados pelos demais Poderes (ou que deveriam ter sido) à ordem jurídica. E assim deve ser efetivamente, já que a medida da intervenção judicial está estritamente relacionada à questão democrática, não sendo dado ao Poder Judiciário desbordar das suas atribuições constitucionais e exercer as funções típicas dos outros Poderes.

Por fim, no último capítulo apresentamos casos colhidos na jurisprudência pátria que fornecem alguns subsídios acerca da interpretação judicial em matéria previdenciária.

Se é certo que o nosso sistema de controle de constitucionalidade não permite traçar um diagnóstico preciso do perfil e das tendências dos juízes brasileiros, pelo menos as decisões proferidas pelo Supremo Tribunal Federal e pelo Superior Tribunal de Justiça possibilitam sejam feitas algumas observações.

Sobretudo a partir da alteração do texto constitucional ocorrida em 1998, por força da Emenda $n^{\circ} 20$, é possível divisar as decisões sobre questões previdenciárias em dois grupos: (i) as primeiras envolvendo, sobretudo, ações individuais, sem grande repercussão 
financeira; (ii) as segundas envolvendo ações individuais e coletivas, com forte repercussão financeira.

Tem-se a impressão de que primeiro se olham os efeitos financeiros da decisão, depois se busca o direito, vale dizer, o direito fundamental só é reconhecido se existir disponibilidade financeira para concretizá-lo, posição frontalmente contrária àquela que acreditamos ser a tônica do Estado Democrático de Direito e que permeia toda a Constituição Federal.

Em outras palavras, assistiu-se, por parte dos juízes, à imediata incorporação da lógica econômica, como premissa absoluta, a partir da qual os novos casos começaram a ser resolvidos. A nós resta claro que em questões jurídicas envolvendo gastos públicos de monta ou que podem configurar precedentes com tais efeitos, o Poder Judiciário tem optado em adotar soluções típicas da lógica econômica, não obstante sua missão precípua seja a guarda da Constituição Federal.

Tais constatações, contudo, não são suficientes para deixarmos de acreditar que, enquanto o Poder Judiciário for o órgão constitucionalmente designado a dizer o Direito, continuará sendo um importante espaço de proteção dos direitos sociais. Necessário, para tanto, que reencontre seu âmbito de atuação e sua função primordial de defesa da ordem jurídica. 


\section{BIBLIOGRAFIA}

AITH, Fernando. Políticas públicas de Estado e de governo: instrumentos de consolidação do Estado de Direito e de promoção dos direitos humanos. In: BUCCI, Maria Paula Dallari (org.). Políticas Públicas: Reflexões sobre o Conceito Jurídico. São Paulo: Saraiva, 2006.

ALEXY, Robert. Teoria dos Direitos Fundamentais. São Paulo: Malheiros Editores, 2008.

ARANTES, Rogério Bastos. Direito e Política: o Ministério Público e a defesa dos direitos coletivos. Revista Brasileira de Ciências Sociais, v. 14, no 39, fevereiro de 1999, p. 83102.

. Judiciário: entre a Justiça e a Política. In: AVELAR, Lúcia; CINTRA, Antônio Octávio.

Sistema Político Brasileiro: uma introdução. 2. ed. rev. e ampl. Rio de Janeiro: KonradAdenauer-Stiftung; São Paulo: Editora Unesp, 2007.

ARANTES, Rogério Bastos; KERCHE, Fábio. Judiciário e Democracia no Brasil. Novos Estudos, nº 54, julho de 1999, p. 27-41.

ÁVILA, Humberto. Teoria dos Princípios: da definição à aplicação dos princípios jurídicos. 4. ed., 3. tir. São Paulo: Malheiros Editores, 2005.

AZEVEDO, Plauto Faraco de. Crítica à dogmática e hermenêutica jurídica. Porto Alegre: Fabris, 1989.

BALEEIRO, Aliomar. Uma introdução à ciência das finanças. 15. ed., rev. e atual. Rio de Janeiro: Forense, 1998.

BARCELlOS, Ana Paula de. A eficácia jurídica dos princípios constitucionais: O princípio da dignidade da pessoa humana. 2. ed. Rio de Janeiro: Renovar, 2008.

BARROS, Marcus Aurélio de Freitas. Controle jurisdicional de políticas públicas: parâmetros objetivos e tutela coletiva. Porto Alegre: Sergio Antonio Fabris Editor, 2008.

BARROS, Suzana de Toledo. O princípio da proporcionalidade e o controle de constitucionalidade das leis restritivas de direitos fundamentais. 2. ed. Brasília: Brasília Jurídica, 2000.

BARROSO, Luís Roberto. O controle de constitucionalidade no direito brasileiro. 2. ed., 4. tir. São Paulo: Saraiva, 2007.

. Interpretação e aplicação da Constituição. São Paulo: Saraiva, 2003.

. O Direito Constitucional e a efetividade de suas normas: limites e possibilidades da Constituição brasileira. Rio de Janeiro: Renovar, 2002. 
. Neoconstitucionalismo e Constitucionalização do Direito (O Triunfo Tardio do Direito Constitucional do Brasil). In NETO, Cláudio Pereira de Souza; SARMENTO, Daniel (coords.). A Constitucionalização do Direito: Fundamentos Teóricos e Aplicações Específicas. Rio de Janeiro: Editora Lumen Juris, 2007.

BASTOS, Celso Ribeiro; MEYER-PFLUG, Samantha. A interpretação como fator de desenvolvimento e atualização das normas constitucionais. In SILVA, Virgílio Afonso da. Interpretação Constitucional. 1. ed., 2. tir. São Paulo: Malheiros Editores, 2007.

BATISTA, Flávio Roberto. Benefícios Previdenciários por Incapacidade no Regime Geral de Previdência Social. Dissertação de Mestrado apresentada na Faculdade de Direito, Universidade de São Paulo, 2008.

BAUMAN, Zygmunt. A sociedade individualizada: vidas contadas e histórias vividas. Rio de Janeiro: Jorge Zahar Editor, 2008.

BEDAQUE, José Roberto dos Santos. Poderes instrutórios do juiz. 3. ed. rev., atual. e ampl. São Paulo: Revista dos Tribunais, 2001.

BERCOVICI, Gilberto. Soberania e Constituição: para uma crítica do constitucionalismo. São Paulo: Quartier Latin, 2008a.

. Tentativa de Instituição da Democracia de Massas no Brasil: Instabilidade Constitucional e Direitos Sociais na Era Vargas (1930-1964). In NETO, Cláudio Pereira de Souza e SARMENTO, Daniel (coords.). Direitos Sociais: fundamentos, judicialização e direitos sociais em espécie. Rio de Janeiro: Editora Lumen Juris, $2008 \mathrm{~b}$.

A Constituição Dirigente e a Constitucionalização de Tudo (ou do Nada). In NETO, Cláudio Pereira de Souza; SARMENTO, Daniel (coords.). A Constitucionalização do Direito: Fundamentos Teóricos e Aplicações Específicas. Rio de Janeiro: Editora Lumen Juris, 2007.

. Planejamento e políticas públicas: por uma nova compreensão do papel do Estado. In BUCCI, Maria Paula Dallari (org.). Políticas Públicas: Reflexões sobre o Conceito Jurídico. São Paulo: Saraiva, 2006.

. Econômica e Desenvolvimento: uma leitura a partir da Constituição de 1988. São Paulo: Malheiros Editores, 2005.

. Constituição e Estado de exceção permanente: atualidade de Weimar. Rio de Janeiro: Azougue Editorial, 2004.

BOBBIO, Norberto. A Era dos Direitos. 8. ed. Rio de Janeiro: Campus, 1992.

. Estado, Governo, Sociedade - Para uma teoria geral da política. 14. ed. São Paulo: Paz e Terra, 2007. 
O futuro da democracia. 10. ed. São Paulo: Paz e Terra, 2006.

BONAVIDES, Paulo. Política e Constituição: os caminhos da democracia. Rio de Janeiro: Forense, 1985.

. Do Estado Liberal ao Estado Social. 6. ed. Rio de Janeiro: Forense, 1996.

. Ciência Política. 10. ed., 3. tir. São Paulo: Malheiros Editores, 1996.

. As quatro crises do Brasil Constitucional. In: SAMPAIO, José Adércio Leite (coord.).

Crise e desafios da Constituição. Belo Horizonte: Del Rey, 2004.

BONFIM, Thiago. Os princípios constitucionais e sua força normativa: análise da prática jurisprudencial. Salvador: Editora JusPodivm, 2008.

BREUS, Thiago Lima. Políticas Públicas no estado constitucional: problemática da concretização dos direitos fundamentais pela Administração Pública brasileira contemporânea. Belo Horizonte: Editora Fórum, 2007.

BUCCI, Maria Paula Dallari. Controle Judicial de Políticas Públicas: Possibilidades e Limites. In BENEVIDES, Maria Victoria de Mesquita; BERCOVICI, Gilberto; MELO, Claudineu de. Direitos Humanos, Democracia e República - Homenagem a Fábio Konder Comparato. São Paulo: Quartier Latin, 2009.

.Notas para uma metodologia jurídica de análise de políticas públicas. In FORTINI, Cristiana; ESTEVES, Júlio César dos Santos; DIAS, Maria Tereza Fonseca (orgs.). Políticas públicas: possibilidades e limites. Belo Horizonte: Editora Fórum, 2008. .O conceito de política pública em direito. In: BUCCI, Maria Paula Dallari (org.). Políticas Públicas: reflexões sobre o conceito jurídico. São Paulo: Saraiva, 2006.

. Direito administrativo e políticas públicas. São Paulo: Saraiva, 2002.

. O princípio da razoabilidade em apoio à legalidade. São Paulo: Revista dos Tribunais Cadernos de Direito Constitucional e Ciência Política - ano 4, $\mathrm{n}^{\mathrm{o}}$ 16, julho-setembro de 1996, p. 173-177.

A Reforma Constitucional da Previdência. O Direito à Aposentadoria como Direito Fundamental e seu Conteúdo. Revista dos Tribunais, ano 3, $\mathrm{n}^{\mathrm{o}} 12$, julho-setembro de 1995, p. 116-129.

BUZAID, Alfredo. Considerações sobre o mandado de segurança coletivo. São Paulo: Saraiva, 1992.

CABRAL, Nazaré da Costa. O financiamento da Segurança Social e suas implicações redistributivas: enquadramento e regime jurídico. Lisboa: Associação Portuguesa da Segurança Social, 2001. 
CALCIOLARI, Ricardo Pires. O orçamento da Seguridade Social e a efetividade dos direitos sociais. Curitiba: Juruá, 2009.

. A crise de efetividade dos direitos sociais e a desvinculação de receitas. In ROCHA, Daniel Machado da; SAVARIS, José Antonio (coords.). Curso de Especialização em Direito Previdenciário, volume 3 - Custeio da Seguridade Social. Curitiba: Juruá Editora, 2008.

CAnOtILHO, José Joaquim Gomes. Direito Constitucional e Teoria da Constituição. 7. ed. (4. reimpr.). Coimbra: Almedina, 2003.

_. Constituição Dirigente e Vinculação do Legislador. Coimbra: Coimbra Editora, 1982.

- Tomemos a sério os cidadãos difíceis. In BENEVIDES, Maria Victoria de Mesquita; BERCOVICI, Gilberto; MELO, Claudineu de. Direitos Humanos, Democracia e República - Homenagem a Fábio Konder Comparato. São Paulo: Quartier Latin, 2009.

CAPELlA, Ana Cláudia N. Perspectivas Teóricas sobre o Processo de Formulação de Políticas Públicas. In HOCHMAN, Gilberto; ARRETCHE, Marta; MARQUES, Eduardo (orgs.). Políticas públicas no Brasil. Rio de Janeiro: Editora Fiocruz, 2007.

CAPPELLETTI, Mauro. O controle judicial de constitucionalidade das leis no direito comparado. 2. ed. Porto Alegre: Sérgio Antonio Fabris Editor, 1992 - reimpr. 1999. . Juízes legisladores? Porto Alegre: Sérgio Antonio Fabris Editor, 1993/reimpr. 1999.

CÉSAR, Afonso. A face oculta e cruel da reforma da Previdência. Brasília: Cedil, 1995.

CLÈVE, Clèmerson Merlin. Atividade legislativa do poder Executivo no Estado contemporâneo e na Constituição de 1988. São Paulo: Revista dos Tribunais, 1993.

O Direito e os Direitos: Elementos para uma crítica do Direito Contemporâneo. 2. ed. São Paulo: Max Limonad, 2001.

COELHO, Inocêncio Mártires. Interpretação Constitucional. São Paulo: Saraiva, 2007.

COMPARATO, Fábio Konder. Ensaio sobre o juízo de constitucionalidade de políticas públicas.

Revista dos Tribunais, ano 86, volume 737, março de 1997, págs. 11-22.

. A afirmação histórica dos direitos humanos. 4. ed. São Paulo: Saraiva, 2005.

CORREIA, Marcus Orione Gonçalves. Legislação Previdenciária Comentada. São Paulo: DPJ, 2008.

. Interpretação do direito da segurança social. In ROCHA, Daniel Machado; SAVARIS, José Antonio (coords.). Curso de Especialização em Direito Previdenciário - volume I - Direito Previdenciário Constitucional. 1. ed. (2005), 2. tir. Curitiba: Juruá Editora, 2006. 
Os direitos sociais enquanto direitos fundamentais. In CORREIA, Marcus Orione Gonçalves; CORREIA, Érica Paula Barcha. Direito Previdenciário e Constituição: homenagem a Wladimir Novaes Martinez. São Paulo: LTr, 2004.

. Teoria e Prática do Poder de Ação na Defesa dos Direitos Sociais. São Paulo: LTr, 2002.

. A jurisprudência e a promoção do bem-estar social em matéria previdenciária. Tese de Doutorado apresentada junto à Faculdade de Direito da Universidade de São Paulo, 1996.

CORREIA, Marcus Orione Gonçalves; CORREIA, Érica Paula Barcha. Curso de Direito da Seguridade Social. 3. ed. São Paulo: Saraiva, 2007.

CORREIA, Marcus Orione Gonçalves; MAIOR, Jorge Luiz Souto. O que é Direito Social? In CORREIA, Marcus Orione Gonçalves (org.). Curso de Direito do Trabalho: teoria geral do Direito do Trabalho. São Paulo: LTr, 2007. v. 1, p. 13-40.

COUTO, Cláudio Gonçalves. Política constitucional, política competitiva e políticas públicas. In BUCCI, Maria Paula Dallari (org.). Políticas Públicas: reflexões sobre o conceito jurídico. São Paulo: Saraiva, 2006.

CRUZ, Maria do Carmo Meirelles. Desafios para o funcionamento eficaz dos Conselhos. In CARVAlHO, Maria do Carmo A. A.; TEIXEIRA, Ana Cláudia C. (org.). Conselhos Gestores de Políticas Públicas. São Paulo: Polis, 2000.

CRUZ, Paulo Márcio. Fundamentos Históricos, Políticos e Jurídicos da Seguridade Social. In ROCHA, Daniel Machado; SAVARIS, José Antonio (coords.). Curso de Especialização em Direito Previdenciário - volume I - Direito Previdenciário Constitucional. 1. ed. (2005), 2. tir. Curitiba: Juruá Editora, 2006.

DAL BOSCO, Maria Goretti. Discricionariedade em Políticas Públicas: um olhar garantista da aplicação da lei de improbidade administrativa. Curitiba: Juruá Editora, 2008.

DALLARI, Dalmo de Abreu. O Poder dos Juízes. 3. ed., rev., 2. tir. São Paulo: Saraiva, 2008.

DERANI, Cristiane. Política pública e a norma política. In BUCCI, Maria Paula Dallari (org.).

Políticas Públicas: reflexões sobre o conceito jurídico. São Paulo: Saraiva. 2006.

DI PIETRO, Maria Sylvia Zanella. Direito Administrativo. 21. ed. São Paulo: Atlas, 2008. . Inovações no Direito Administrativo Brasileiro. Interesse Público - ano VI - 2005 - $\mathrm{n}^{\circ}$ 30, p. 39-55.

DIAS, Jean Carlos. O controle judicial de políticas públicas. São Paulo: Método, 2007.

DINAMARCO, Cândido Rangel. A instrumentalidade do processo. 13. ed., rev. e atual. São Paulo: Malheiros Editores, 2008. 
DUARTE, Clarice Seixas. O Direito Público Subjetivo: História de um Debate. In BENEVIDES, Maria Victoria de Mesquita; BERCOVICI, Gilberto; MELO, Claudineu de. Direitos Humanos, Democracia e República - Homenagem a Fábio Konder Comparato. São Paulo: Quartier Latin, 2009.

DUARTE, Écio Oto Ramos; POZZOLO, Susanna. Neoconstitucionalismo e positivismo jurídico: as faces da teoria do Direito em tempos de interpretação moral da Constituição. São Paulo: Landy Editora, 2006.

DWORKIN, Ronald. O Império do Direito. 2. ed. São Paulo: Martins Fontes, 2007. . Uma questão de princípio. 2. ed. São Paulo: Martins Fontes, 2005.

ESPÍNDOLA, Ruy Samuel. Conceito de princípios constitucionais. São Paulo: Revista dos Tribunais, 1999.

ESPING-ANDERSEN, Gosta. As três economias políticas do Welfare State. Lua Nova, $n^{\circ} 24$, setembro de 1991, p. 85-116. . Uma perspectiva transatlântica da política de privatização latino-americana. In COELHO, Vera Schattan P. (org.). A Reforma da Previdência Social na América Latina. Rio de Janeiro: Editora FGV, 2003.

ESTEVES, João Luiz M. Direitos Fundamentais Sociais no Supremo Tribunal Federal. São Paulo: Método, 2007.

FAGNANI, Eduardo. Previdência social e desenvolvimento econômico. Texto para discussão. IE/UNICAMP, Campinas, nº 140, fev. 2008.

. Os profetas do caos e o debate recente sobre a Seguridade Social no Brasil. In FAGNANI, Eduardo; HENRIQUE, Wilnês; LÚCIO, Clemente Ganz. Previdência Social: Como Incluir os Excluídos? Uma agenda voltada para o desenvolvimento econômico com distribuição de renda. Campinas: UNICAMP - Instituto de Economia; Campinas: CESIT; São Paulo: LTr, 2008.

FAZENDA, Ivani. Interdisciplinaridade: História, Teoria e Pesquisa. Campinas: Papirus Editora, 1994.

Interdisciplinaridade: um projeto em parceria. São Paulo: Edições Loyola, 2002.

FERRARI, Regina Maria Macedo Nery. Normas Constitucionais Programáticas: normatividade, operatividade e efetividade. São Paulo: Revista dos Tribunais, 2001.

FISS, Owen. A autonomia do direito. In SAMPAIO, José Adércio Leite (coord.). Constituição e crise política. Belo Horizonte: Del Rey, 2006. 
FRANCO, Fábio Luiz; MARTINS, Antonio Darienso. A ação civil pública como instrumento de controle das políticas públicas. Revista de Processo, ano 31, maio 2006, p. 34-70. São Paulo: Revista dos Tribunais.

FREEMAN, Samuel. Democracia e Controle Jurídico da Constitucionalidade. Lua Nova, 1994, volume 32, p. 181-199.

FRISCHEISEN, Luiza Cristina Fonseca. Políticas públicas: a responsabilidade do administrador e o Ministério Público. São Paulo: Max Limonad, 2000.

GALDINO, Flávio. Introdução à Teoria dos Custos dos Direitos - Direitos Não Nascem em Árvores. Rio de Janeiro: Editora Lúmen Júris, 2005.

GARAPON, Antoine. O juiz e a democracia: o guardião de promessas. 2. ed. Rio de Janeiro: Revan, 2001.

GASPARINI, Diógenes. Direito Administrativo. 10. ed. São Paulo: Saraiva, 2005.

GENTIL, Denise Lobato. A política fiscal e a falsa crise do sistema de seguridade social no Brasil: análise financeira do período recente. In SICSÚ, João (org.). Arrecadação (de onde vem?) e gastos públicos (para onde vão?). São Paulo: Boitempo, 2007.

GOHN, Maria da Glória. Os Conselhos de Educação e a Reforma do Estado. In CARVALHO, Maria do Carmo A. A.; TEIXEIRA, Ana Cláudia C. (org.). Conselhos Gestores de Políticas Públicas. São Paulo: Polis, 2000.

. Conselhos Gestores e Participação Sociopolítica. 3. ed. São Paulo: Editora Cortez, 2007, coleções questões da nossa época - volume 84.

GONÇALVES, Alcindo. Políticas públicas e a ciência política. In BUCCI, Maria Paula Dallari (org.). Políticas Públicas: Reflexões sobre o Conceito Jurídico. São Paulo: Saraiva, 2006.

GRAU, Eros Roberto. A ordem econômica na Constituição de 1988. 13. ed., rev. e atual. São Paulo: Malheiros Editores, 2008.

. Planejamento econômico e regra jurídica. São Paulo: Revista dos Tribunais, 1977.

GRINOVER, Ada Pellegrini. O controle de políticas públicas pelo Poder Judiciário. In GRINOVER, Ada Pellegrini. O Processo: Estudos \& Pareceres. 2. ed. rev. e ampl. São Paulo: Editora DPJ, 2009a.

- O controle difuso da constitucionalidade e a coisa julgada erga omnes das ações coletivas. In GRINOVER, Ada Pellegrini. O Processo: Estudos \& Pareceres. 2. ed. rev. e ampl. São Paulo: Editora DPJ, 2009b. 
. Garantia de acesso à justiça com efetividade. In MILARÉ, Édis (coord.). A ação civil pública após 20 anos: efetividade e desafios. São Paulo: Revista dos Tribunais, 2005.

. A marcha do processo. Rio de Janeiro: Forense Universitária, 2000.

GUERRA, Sidney. Hermenêutica, Ponderação e Colisão de Direitos Fundamentais. Rio de Janeiro: Lumen Iuris Editora, 2007.

HARVEY, David. O Neoliberalismo - história e implicações. São Paulo: Edições Loyola, 2008.

HOLMES, Stephen; SUNSTEIN, Cass R. The Cost of Rigths - why liberty depends on taxes. New York: W.W. Norton \& Company, 1999.

JAPIASSU, Hilton. As Paixões da Ciência: Estudos de História das Ciências. São Paulo: Letras \& Letras, 1991.

. Interdisciplinaridade e Patologia do Saber. Rio de Janeiro: Imago Editora Ltda., 1976.

KELLER, Arno Arnoldo. O Descumprimento dos Direitos Sociais. São Paulo: LTr, 2001.

KERCHE, Fábio. Autonomia e discricionariedade do Ministério Público do Brasil. Rio de Janeiro, Dados, volume 50, n. 2, 2007.

. O Ministério Público e a Constituinte de 1987/88. In SADEK, Maria Tereza (org.). O sistema de justiça. São Paulo: IDESP: Sumaré, 1999.

KINGDON, John W. Agendas, alternatives, and public policies. 2. ed. New York: Longman, 1995.

KRELL, Andreas J. Direitos sociais e controle judicial no Brasil e na Alemanha: os (des)caminhos de um direito constitucional 'comparado'. Porto Alegre: Sérgio Antonio Fabris Editor, 2002.

LASSALLlE, Ferdinand. O que é uma Constituição? Porto Alegre: Editorial Villa Martha, 1980.

LEAL, Rogério Gesta. O Estado-Juiz na democracia contemporânea: uma perspectiva procedimentalista. Porto Alegre: Livraria do Advogado Editora, 2007.

LEDUR, José Felipe. Direitos Fundamentais Sociais: efetivação no âmbito da democracia participativa. Porto Alegre: Livraria do Advogado Editora, 2009.

LEIVAS, Paulo Gilberto Cogo. Estrutura Normativa dos Direitos Fundamentais Sociais e o Direito Fundamental ao Mínimo Existencial. In NETO, Cláudio Pereira de Souza e SARMENTO, Daniel (coords.). Direitos Sociais: fundamentos, judicialização e direitos sociais em espécie. Rio de Janeiro: Editora Lumen Juris, 2008.

- Teoria dos Direitos Fundamentais Sociais. Porto Alegre: Livraria do Advogado Editora, 2006. 
LIMA, Ruy Cerne. Princípios de Direito Administrativo. 7. ed., rev. e reelab. por Paula Alberto Pasqualini. São Paulo: Malheiros Editores, 2007.

LOPES, José Reinaldo de Lima. Direitos sociais - teoria e prática. São Paulo: Método, 2006.

. Direito Subjetivo e Direitos Sociais: O dilema do Judiciário no Estado Social de Direito. In FARIA, José Eduardo (org.). Direitos Humanos, Direitos Sociais e Justiça. 1. ed., 4. tir. São Paulo: Malheiros Editores, 2005.

MACEDO, Regina Maria; FERRARI, Nery. Normas Constitucionais Programáticas: normatividade, operatividade e efetividade. São Paulo: Revista dos Tribunais, 2001.

MANCUSO, Rodolfo de Camargo. Ação Civil Pública: em defesa do meio ambiente, do patrimônio cultural e dos consumidores. 10. ed. rev. e atual. São Paulo: Revista dos Tribunais, 2007a.

- Ação Civil Pública: Instrumento de participação na tutela do bem comum. In Participação e Processo, 2007b.

A ação civil pública como instrumento de controle judicial das chamadas políticas públicas. In MILARÉ, Édis (coord.). Ação Civil Pública: Lei 7.347/85 - 15 anos. 2. ed. São Paulo: Revista dos Tribunais, 2002.

MARINONI, Luiz Guilherme. Teoria Geral do Processo. 3. ed. rev. e atual. São Paulo: Revista dos Tribunais, 2008.

MARTINEZ, Wladimir Novaes. Princípios de Direito Previdenciário. 4. ed. São Paulo: LTr, 2001.

MASSA-ARZABE, Patrícia Helena. Dimensão jurídica das Políticas públicas. In BUCCI, Maria Paula Dallari (org.). Políticas Públicas: reflexões sobre o conceito jurídico. São Paulo: Saraiva, 2006.

. O direito à proteção contra a pobreza e a exclusão social. Tese de doutorado, apresentada no ano de 2001, na Universidade de São Paulo - Faculdade de Direito.

MASTRODI, Josué. Direitos Sociais Fundamentais. Rio de Janeiro: Editora Lumen Juris, 2008.

MEDAUAR, Odete. Direito Administrativo Moderno. 10. ed. São Paulo: Revista dos Tribunais, 2006.

MELLO, Celso Antonio Bandeira. Eficácia das Normas Constitucionais e Direitos Sociais. São Paulo: Malheiros Editores, 2009.

. Curso de Direito Administrativo. 25. ed., rev. e atual., 2. tir. São Paulo: Malheiros Editores, 2007.

. Eficácia das Normas Constitucionais sobre Justiça Social. Revista de Direito Público, Ano XIV, janeiro/junho - 1981, ns. 57-58, p. 233-256. 
MELO, Marcus André. Escolha Institucional e a difusão dos paradigmas de política: o Brasil e a segunda onda de reformas previdenciárias. Rio de Janeiro, Dados, volume 47, nº 1, janeiro 2004.

. Reformas Constitucionais no Brasil - Instituições Políticas e Processo Decisório. Rio de Janeiro: Editora Revan, 2002.

As Reformas Constitucionais e a Previdência Social (1993-1996), In DINIZ, Eli e AZEVEDO, Sérgio de (orgs.). Reforma do Estado e Democracia no Brasil. Brasília: Editora Universidade de Brasília, 1997.

. O Jogo das Regras - A Política da reforma constitucional de 1993/96. In http://www.anpocs.org.br/portal/publicacoes/rbcs_00_33/rbcs33_05.htm).

MENDES, Conrado Hübner. Controle de constitucionalidade e democracia. Rio de Janeiro: Elsevier, 2008.

MESA-LAGO, Carmelo. A reforma estrutural dos benefícios de seguridade social na América Latina: modelos, características, resultados e lições. In COELHO, Vera Schattan P. (org.). A Reforma da Previdência Social na América Latina. Rio de Janeiro: Editora FGV, 2003.

MESA-LAGO; Carmelo; MÜLLER, Katharina. Política e reforma da previdência na América Latina. In COELHO, Vera Schattan P. (org.). A Reforma da Previdência Social na América Latina. Rio de Janeiro: Editora FGV, 2003.

MORAIS, José Luis Bolzan de. As crises do Estado e da Constituição e a transformação espacial dos direitos humanos. Porto Alegre: Livraria do Advogado Editora, 2002.

MORO, Sérgio Fernando. Jurisdição Constitucional como Democracia. São Paulo: Revista dos Tribunais, 2004.

. Desenvolvimento e efetivação judicial das normas constitucionais. São Paulo: Max Limonad, 2001.

. Legislação suspeita? Afastamento da presunção de constitucionalidade da lei. Curitiba: Juruá, 1998.

NASCIMENTO, Sérgio. Interpretação do Direito Previdenciário. São Paulo: Quartier Latin, 2007.

NETO, Cláudio Pereira de Souza. A Justiciabilidade dos Direitos Sociais: Críticas e Parâmetros. In NETO, Cláudio Pereira de Souza e SARMENTO, Daniel (coords.). Direitos Sociais: fundamentos, judicialização e direitos sociais em espécie. Rio de Janeiro: Editora Lumen Juris, 2008. 
- Teoria da Constituição, Democracia e Igualdade. In NETO, Cláudio Pereira de Souza; BERCOVICI, Gilberto; FILHO, José Filomeno de Moraes e LIMA, Martonio

Mont'Alverne B. Teoria da Constituição: Estudos sobre o Lugar da Política no Direito Constitucional. Rio de Janeiro: Editora Lumen Juris, 2003.

NEVES, José. Privatização da Previdência Social: nove equívocos e uma incógnita. In CÉSAR, Afonso. A face oculta e cruel da reforma da Previdência. Brasília: Cedil, 1995.

NOVAIS, Jorge Reis. Direitos Fundamentais: Triunfos contra a maioria. Coimbra: Coimbra Editora, 2006.

- As restrições aos direitos fundamentais não expressamente autorizadas pela Constituição. Coimbra: Coimbra Editora, 2003.

OLIVEIRA, José Roberto Pimenta. Os princípios da razoabilidade e da proporcionalidade no Direito Administrativo Brasileiro. São Paulo: Malheiros Editores, 2006.

OLSEN, Ana Carolina Lopes. Direitos Fundamentais Sociais: Efetividade frente à reserva do possível. Curitiba: Juruá Editora, 2008.

PALU, Oswaldo Luiz. Controle dos atos de governo pela jurisdição. São Paulo: Editora Revista dos Tribunais, 2004.

PAULANI, Leda Maria. Seguridade Social, regimes previdenciários e padrão de acumulação: uma nota teórica e uma reflexão sobre o Brasil. In FAGNANI, Eduardo; HENRIQUE, Wilnês; LÚCIO, Clemente Ganz. Previdência Social: Como Incluir os Excluídos? Uma agenda voltada para o desenvolvimento econômico com distribuição de renda. Campinas: UNICAMP - Instituto de Economia; Campinas: CESIT; São Paulo: LTr, 2008.

PEREIRA, Luiz Carlos Bresser. Reforma do Estado para a Cidadania: a Reforma Gerencial Brasileira na Perspectiva Internacional. São Paulo: Editora 34, 1998 (1. reimpr. - 2002). . Crise Econômica e Reforma do Estado no Brasil: para uma nova interpretação da América Latina. São Paulo: Editora 34, 1996.

PEREZ, Marcos Augusto. A participação da sociedade na formulação, decisão e execução das políticas públicas. In BUCCI, Maria Paula Dallari (org.). Políticas Públicas: Reflexões sobre o Conceito Jurídico. São Paulo: Saraiva, 2006.

PINHEIRO, Vinicius C. A Experiência Brasileira. In Anais do Seminário Regional sobre as Reformas dos Sistemas de Pensão na América Latina. Brasília, MPAS.

RAMOS, Elival da Silva. Parâmetros Dogmáticos do Ativismo Judicial em Matéria Constitucional. Tese apresentada à Faculdade de Direito da Universidade de São Paulo para inscrição em concurso público visando ao provimento de cargo de professor titular, 
junto do Departamento de Direito do Estado - área de Direito Constitucional. São Paulo, 2009.

RAWLS, John. Uma teoria da Justiça. São Paulo: Martins Fontes, 2002.

O liberalismo político. Lisboa: Editorial Presença, 1997.

REIS, José Carlos Vasconcellos dos. As Normas Constitucionais Programáticas e o Controle do Estado. Rio de Janeiro: Renovar, 2003.

RIBEIRO, Maria Teresa de Melo. O princípio da imparcialidade da Administração Pública. Coimbra: Almedina, 1996.

ROCHA, Daniel Machado da. As aposentadorias dos servidores públicos e as reformas constitucionais. In ROCHA, Daniel Machado; SAVARIS, José Antonio (coords.). Curso de Especialização em Direito Previdenciário - volume I - Direito Previdenciário Constitucional. 1. ed. (2005), 2. tir. Curitiba: Juruá Editora, 2006.

O Direito Fundamental à Previdência Social na perspectiva dos princípios constitucionais diretivos do sistema previdenciário brasileiro. Porto Alegre: Livraria do Advogado Editora, 2004.

ROTHENBURG, Walter Claudius. Princípio da proporcionalidade. In NETO, Olavo de Oliveira e LOPES, Maria Elizabeth de Castro (orgs.). Princípios Processuais Civis na Constituição. Rio de Janeiro: Elsevier, 2008.

. Princípios Constitucionais. 2. tir. Porto Alegre: Sérgio Antonio Fabris, 2003.

SADEK, Maria Tereza. A Organização do Poder Judiciário no Brasil. In SADEK, Maria Tereza (org.). Uma Introdução ao Estudo da Justiça. São Paulo: Idesp/Editora Sumaré, 1995.

- Poder Judiciário e Democracia: Uma visita a "O Poder Judiciário no Regime Democrático". BUCCI, Maria Paula Dallari. Controle Judicial de Políticas Públicas: Possibilidades e Limites. In BENEVIDES, Maria Victoria de Mesquita; BERCOVICI, Gilberto; MELO, Claudineu de. Direitos Humanos, Democracia e República Homenagem a Fábio Konder Comparato. São Paulo: Quartier Latin, 2009.

SALLES, Carlos Alberto de. Processo Civil de Interesse Público. In SALLES, Carlos Alberto de (org.). Processo civil e interesse público: o processo como instrumento de defesa social. São Paulo: Revista dos Tribunais, 2003.

. Políticas Públicas e Processo: a questão da legitimidade nas ações coletivas. In BUCCI, Maria Paula Dallari (org.). Políticas Públicas: Reflexões sobre o Conceito Jurídico. São Paulo: Saraiva, 2006.

SAMPAIO, José Adércio Leite. Mito e História da Constituição: Prenúncios sobre a Constitucionalização do Direito. In NETO, Cláudio Pereira de Souza; SARMENTO, 
Daniel (coords.). A Constitucionalização do Direito: Fundamentos Teóricos e Aplicações Específicas. Rio de Janeiro: Editora Lumen Juris, 2007.

SANTOS, Nelson Rodrigues dos. Implantação e funcionamento dos Conselhos de Saúde no Brasil. In CARVAlHO, Maria do Carmo A. A.; TEIXEIRA, Ana Cláudia C. (orgs.). Conselhos Gestores de Políticas Públicas. São Paulo: Pólis, 2000.

SARLET, Ingo Wolfang. Dignidade da Pessoa Humana e Direitos Fundamentais na Constituição Federal de 1988. 5. ed. Porto Alegre: Livraria do Advogado Editora, 2007a. . A eficácia dos direitos fundamentais. 9. ed., rev., atual. e ampl. Porto Alegre: Livraria do Advogado Editora, 2007b.

SARMENTO, Daniel. A Proteção Judicial dos Direitos Sociais: Alguns Parâmetros ÉticoJurídicos. In NETO, Cláudio Pereira de Souza e SARMENTO, Daniel (coords.). Direitos Sociais: fundamentos, judicialização e direitos sociais em espécie. Rio de Janeiro: Editora Lumen Juris, 2008.

. Ubiquidade Constitucional: os dois lados da moeda. In NETO, Cláudio Pereira de Souza; SARMENTO, Daniel (coords.). A Constitucionalização do Direito: Fundamentos Teóricos e Aplicações Específicas. Rio de Janeiro: Editora Lumen Juris, 2007.

. Os Direitos Fundamentais nos Paradigmas Liberal, Social e Pós-Social (Pós-Modernidade Constitucional?). In SAMPAIO, José Adércio Leite (coord.). Crise e desafios da Constituição. Belo Horizonte: Del Rey, 2004.

SAVARIS, José Antonio. Direito Processual Previdenciário. Curitiba: Juruá, 2008a.

O Judiciário e a Política de Retração Sistemática da Previdência Social no Brasil. In FAGNANI, Eduardo; HENRIQUE, Wilnês; LÚCIO, Clemente Ganz. Previdência Social: Como Incluir os Excluídos? Uma agenda voltada para o desenvolvimento econômico com distribuição de renda. Campinas: UNICAMP - Instituto de Economia; Campinas: CESIT; São Paulo: LTr, 2008b.

SCAFF, Fernando Facury. Sentenças aditivas, direitos sociais e reserva do possível. In SARLET, Ingo Wolfang; TIMM, Luciano Benetti (orgs.). Direitos Fundamentais: orçamento e 'reserva do possível'. Porto Alegre: Livraria do Advogado Editora, 2008.

SILVA, José Afonso da. Aplicabilidade das normas constitucionais. 7. ed., 2. tir. São Paulo: Malheiros Editores, 2008.

. Poder Constituinte e Poder Popular (estudos sobre a Constituição). 1. ed, 3. tir. São Paulo: Malheiros Editores, 2007. 
SILVA, Sandoval Alves da. As leis orçamentárias como instrumento de implementação dos direitos fundamentais sociais. Dissertação de mestrado apresentada em 2005, junto à Universidade Federal do Pará, orientada pelo Prof. Dr. Fernando Facury Scaff.

SILVA, Virgílio Afonso da. Direitos Fundamentais: conteúdo essencial, restrições e eficácia. São Paulo: Malheiros Editores, 2009. . Interpretação Constitucional e Sincretismo Metodológico. In SILVA, Virgílio Afonso da. Interpretação Constitucional. 1. ed., 2. tir. São Paulo: Malheiros Editores, 2007.

SouZA, Artur César de. A Parcialidade Positiva do Juiz. São Paulo: Revista dos Tribunais, 2008.

SOUZA, Celina. Estado da Arte da Pesquisa em Políticas Públicas. In HOCHMAN, Gilberto; ARRETCHE, Marta; MARQUES, Eduardo (orgs.). Políticas públicas no Brasil. Rio de Janeiro: Editora Fiocruz, 2007.

STEPHANES, Reinhold. Reforma da Previdência sem segredos. Rio de Janeiro: Record, 1998.

STRECK, Lenio Luiz. Análise Crítica da Jurisdição constitucional e das possibilidades hermenêuticas de concretização dos direitos fundamentais. In SCAFF, Fernando Facury (org.). Constitucionalizando Direitos: 15 anos da Constituição Brasileira de 1988. Rio de Janeiro: Renovar, 2003.

. O papel da jurisdição constitucional na realização dos direitos sociais-fundamentais. In SARLET, Ingo Wolfang (org.). Direitos Fundamentais Sociais: Estudos de Direito Constitucional, Internacional e Comparado. Rio de Janeiro: Renovar, 2003.

TATE, C. Neal; VALLINDER, Torbjörn. The Global Expansion of Judicial Power. Nova York: New York University Press, 1995.

TAVARES, Marcelo Leonardo. A Constitucionalização do Direito Previdenciário. In NETO, Cláudio Pereira de Souza; SARMENTO, Daniel (coords.). A Constitucionalização do Direito: Fundamentos Teóricos e Aplicações Específicas. Rio de Janeiro: Lumen Juris, 2007.

. Princípios Constitucionais dos direitos fundamentais e o limite à reforma da previdência social. In ROCHA, Daniel Machado; SAVARIS, José Antonio (coords.). Curso de Especialização em Direito Previdenciário - volume I - Direito Previdenciário Constitucional. 1. ed. (2005), 2. tir. Curitiba: Juruá Editora, 2006.

. Reforma da Previdência - um resumo da mudança. In TAVARES, Marcelo Leonardo (coord.). Direito Previdenciário. Niterói: Impetus, 2005.

TAYLOR, Matthew. O judiciário e as políticas públicas no Brasil. DADOS - Revista de Ciências Sociais, 2007, v. 50, n. 2, p. 229-257. 
TORRES, Ricardo Lobo (org.). O Mínimo Existencial como Conteúdo Essencial dos Direitos Fundamentais. In NETO, Cláudio Pereira de Souza e SARMENTO, Daniel (coords.). Direitos Sociais: fundamentos, judicialização e direitos sociais em espécie. Rio de Janeiro: Lumen Juris, 2008.

. A metamorfose dos direitos sociais em mínimo existencial. In SARLET, Ingo Wolfang (org.). Direitos Fundamentais Sociais: Estudos de Direito Constitucional, Internacional e Comparado. Rio de Janeiro: Renovar, 2003.

. O orçamento na Constituição. Rio de Janeiro: Renovar, 1995.

VALLE, Vanice Lírio do. Constitucionalização das políticas públicas e seus reflexos no controle. Fórum Administrativo - Direito Público, Belo Horizonte, ano 8, n 95, pág. 7-21, março-2008.

VELLOSO, Andrei Pitten; ROCHA, Daniel Machado da; JÚNIOR, José Paulo Baltazar. Comentários à Lei do Custeio da Seguridade Social. Porto Alegre: Editora Livraria do Advogado, 2005.

VERISSIMO, Marcos Paulo. A judicialização dos conflitos de justiça distributiva no Brasil: o processo judicial no pós-88. Tese de doutorado, apresentada no ano de 2006, na Universidade de São Paulo - Faculdade de Direito.

WALDRON, Jeremy. A dignidade da legislação. São Paulo: Martins Fontes, 2003. 